\title{
Procesoptimalisatie van gedragsinterventies
}

Citation for published version (APA):

Rauner, M. (2015). Procesoptimalisatie van gedragsinterventies. [Doctoral Thesis, Maastricht University]. Maastricht University. https://doi.org/10.26481/dis.20151214mr

Document status and date:

Published: 01/01/2015

DOI:

10.26481/dis.20151214mr

Document Version:

Publisher's PDF, also known as Version of record

\section{Please check the document version of this publication:}

- A submitted manuscript is the version of the article upon submission and before peer-review. There can be important differences between the submitted version and the official published version of record.

People interested in the research are advised to contact the author for the final version of the publication, or visit the DOI to the publisher's website.

- The final author version and the galley proof are versions of the publication after peer review.

- The final published version features the final layout of the paper including the volume, issue and page numbers.

Link to publication

\footnotetext{
General rights rights.

- You may freely distribute the URL identifying the publication in the public portal. please follow below link for the End User Agreement:

www.umlib.nl/taverne-license

Take down policy

If you believe that this document breaches copyright please contact us at:

repository@maastrichtuniversity.nl

providing details and we will investigate your claim.
}

Copyright and moral rights for the publications made accessible in the public portal are retained by the authors and/or other copyright owners and it is a condition of accessing publications that users recognise and abide by the legal requirements associated with these

- Users may download and print one copy of any publication from the public portal for the purpose of private study or research.

- You may not further distribute the material or use it for any profit-making activity or commercial gain

If the publication is distributed under the terms of Article $25 \mathrm{fa}$ of the Dutch Copyright Act, indicated by the "Taverne" license above, 


\section{Procesoptimalisatie van gedragsinterventies}

Een integraal raamwerk ter versterking van de effectiviteit

van (gedrags)interventies in organisaties gebaseerd op de principes van de 'Reasoned Action Approach' en 'Intervention Mapping'

Michael Rauner 
ISBN | 978-90-9029351-6 (1e druk)

Redactie | Rianne (M.) A.L. Blacquière \& Jacques Leuven

Vormgeving | Rianne (M.) A.L. Blacquière \& Michael Rauner

Printing | Jakarta (Indonesia), SMK Grafika Desa Putera

Copyright (c) 2015 Michael Rauner | Cascade-Advies (bureau voor management- en organisatieadvies), Voorburg, info@cascade-advies.nl.

Alle rechten voorbehouden. Alles uit deze uitgave mag worden gebruikt, verveelvoudigd, opgeslagen in een geautomatiseerd gegevensbestand en/of openbaar gemaakt in enige vorm of op enige wijze, hetzij elektronisch, mechanisch, door fotokopieën, opnamen of op enige andere manier met voorafgaande schriftelijke toestemming van de auteur. 


\section{Procesoptimalisatie van gedragsinterventies}

Een integraal raamwerk ter versterking van de effectiviteit van (gedrags)interventies in organisaties gebaseerd op de principes van de 'Reasoned Action Approach' en 'Intervention Mapping'

\section{PROEFSCHRIFT}

Ter verkrijging van de graad van doctor aan de Universiteit Maastricht,

Op gezag van de Rector Magnificus, Prof. dr. L.L.G. Soete, volgens het besluit van het College van Decanen,

in het openbaar te verdedigen

op maandag 14 december 2015 om 16.00 uur

door

Michael Heinz Dieter Rauner 


\section{Promotoren}

Prof. dr. G. Kok

Prof. dr. T. Taris (Universiteit Utrecht)

\section{Beoordelingscommissie}

Prof. dr. F. Nijhuis $+(v z)$

Dr. G-J. Y. Peters (Open Universiteit)

Prof. dr. R. Ruiter

Prof. dr. N. de Vries

Dr. W. Weijts (Weijts Coaching \& Training) 


\section{Voorwoord}

Het idee voor dit proefschrift is al vroeg in mijn werk als trainer en organisatieadviseur, in 1998, ontstaan. Na honderden groepen en nog meer deelnemers te hebben begeleid, zag ik dat mensen daadwerkelijk tijdens een training van gedrag konden veranderen en had ik het gevoel dat de door mij geboden interventies effect konden opleveren. Echter, een wetenschappelijke basis, alsmede de verandering in de praktijk bleven voor mij in de meeste gevallen verborgen. Het contact met een deelnemer was in de regel beperkt tot de training en ook de evaluatieformulieren gaven geen uitsluitsel over het effect in de praktijk. Mijn twee basisvragen voor dit onderzoek zijn dan ook: Hoe kan het effect van gedragsinterventies worden gemeten en hoe kan het proces daarvan worden geoptimaliseerd?

In de praktijk bestonden weinig aanknopingspunten om een gedegen antwoord op deze vragen te kunnen geven. Temeer omdat goed gedocumenteerde onderzoeken op het gebied van gedragstrainingen in organisaties schaars waren of in een "skills lab"-achtige omgeving waren uitgevoerd. Een ander probleem bij bedrijfstrainingen is de kleine steekproefomvang, het ontbreken van meerdere meetmomenten, de korte duur van de interventie en het ontbreken van een controlegroep. Maar de wens tot meer inzicht in de resultaten van mijn werk en dat van mijn vakgenoten is in al die jaren steeds groter geworden. Zeker omdat bij mij de verbazing toenam over hoe het toch mogelijk was, dat een persoon of organisatie enkele duizenden euro's aan een niet wetenschappelijk onderbouwde (gedrags)training of interventie wil uitgeven, terwijl het effect daarvan niet is aangetoond, en dit in tegenstelling tot bijvoorbeeld behandelingen in de medische wereld, waarbij voor iedere interventie veelvuldige effectstudies worden verwacht. Kennelijk is men bij een medische behandeling veel kritischer, terwijl deze in veel gevallen veel goedkoper is dan een gemiddelde managementopleiding (neem bijvoorbeeld operatie van huidkanker gemiddeld $€ 540$, plaatsen van een spiraaltje in een ziekenhuis gemiddeld $€ 420$ of een knieoperatie gemiddeld $€ 2.192$; bron: www.watkostdezorg. $n l)$. Nu is dat natuurlijk inhoudelijk geheel iets anders: de gevolgen bij een medische ingreep zijn direct merkbaar en kunnen voor de betreffende persoon zeer negatief zijn. Bij een training is dit effect minder duidelijk en heerst vaak toch een gevoel van 'baat het niet, dan schaadt het ook niet'. Voor mij gaf dit vraagstuk voldoende aanleiding om het verder uit te zoeken.

$\mathrm{Na}$ een uitgebreide literatuurstudie en gesprekken met vakgenoten was in 2001 mijn aandacht al snel gericht op de inzichten van de 'Reasoned Action Approach' (Fishbein \& Ajzen, 2010) en de principes van 'Intervention Mapping' (Bartholomew et al., 2001; 2006), waarmee het startschot voor dit onderzoek gegeven was. Voor mij als gezondheidswetenschapper was bovendien de vraag interessant of deze twee concepten, die in een zorgcontext veelvuldig worden toegepast en waarvan de toepassing in de praktijk goed onderzocht is, ook in een bedrijfsmatige context kunnen worden toegepast. Omdat de theoretische basis voor mijn vraagstuk zowel de gezondheidspsychologie als de organisatiepsychologie betreft, heeft de wetenschappelijke begeleiding zowel door prof. dr. G. Kok (Universiteit Maastricht) als door prof. dr. T. Taris (Universiteit Utrecht) plaatsgevonden - een combinatie die mij op inhoudelijk en persoonlijk vlak zeer heeft geholpen bij de verdere invulling van dit onderzoek.

De grootste uitdaging in dit hele traject lag bij het vinden van geschikte opdrachtgevers die aan een dergelijk onderzoek wilden meewerken en het vinden van voldoende deelnemers om goede analyses uit te kunnen voeren. Aan interesse was er in eerste instantie geen gebrek en na uitleg over de praktische mogelijkheden van dit onderzoek (effect meten en de interventie 
effectiever maken) wilden veel organisaties meer weten over de praktische toepassing van dit onderzoek.

Echter, nadat voor hen duidelijk was geworden, dat zij zelf ook het nodige werk moesten verrichten (inzet van een controlegroep, het aantal uren dat deelnemers extra moeten bijdragen aan het onderzoek, werken volgens protocol, interviews, een stuurgroep inrichten en de nodige tijd door de opdrachtgever zelf) en dat de mogelijkheid bestond, dat een dergelijke onderzoek ook de effectiviteit van bijvoorbeeld de leiding (opdrachtgever) in kaart zou kunnen brengen, werd het aantal organisaties dat daadwerkelijk wilde meedoen een stuk overzichtelijker. Een ander praktisch probleem bij het inrichten van dit onderzoek betrof de statistische uitwerking. Ten eerste kwam door het aspecifieke karakter van de trainingsdoelstellingen (bijvoorbeeld resultaatgerichter werken of persoonlijke effectiviteit) en de zelfrapportage van de uitkomstvariabele door de deelnemers veelal de validiteit onder druk te staan. Ten tweede was er sprake van een kleine steekproefomvang (een feit waarmee trainingsbureaus juist deelnemers werven), wat een gedegen statistische verwerking belemmert, een veel voorkomend probleem (Salas \& Cannon-Bowers, 2001), dat zich bijvoorbeeld ook bij klinische studies voordoet (Wells, 1999). Ten derde bleek bij het opzetten van het onderzoeksdesign, dat de beoogde trainingsgroepen vaak klein van omvang waren (ongeveer 8-10 personen), een controlegroep ontbrak, de deelnemers een verschillende achtergrond hadden (of zelfs uit verschillende organisaties kwamen) en de interventies (trainingen) kortdurend van aard waren, waardoor longitudinaal onderzoek of de toepassing van meerdere metingen niet mogelijk was.

Uiteindelijk hebben drie organisaties hun medewerking aan dit proefschrift verleend en zijn er in een daarvan meerdere deelonderzoeken uitgevoerd. De ontwikkeling van een raamwerk en het meetinstrument op basis van de principes van de 'Reasoned Action Approach' en 'Intervention Mapping' heeft meerdere jaren (tot 2005) in beslag genomen. In de periode 20062009 zijn de verzamelde resultaten in de praktijk toegepast en is een aantal artikelen/papers gepubliceerd. Bij de vertaling en toepassing van de principes van de 'Reasoned Action Approach' en 'Intervention Mapping' bleek onder andere de geringe steekpoefomvang en de operationalisatie van eenduidig en waarneembaar gedrag een struikelblok voor de statistische verwerking van dit onderzoek. Hiermee is bij de onderzoeken binnen de gegeven omstandigheden enigszins rekening gehouden en met de toepassing van de Internal Referencing Strategy (IRS) een bescheiden mogelijkheid ontwikkeld om ook zonder controlegroep een interventie/controleonderzoek uit te voeren. Door de aard van het onderzoek (in de praktijk en binnen de aangeboden trainingen) is vanuit wetenschappelijk oogpunt zeker niet voor de meest optimale onderzoeksopzet gekozen en derhalve ook niet voor de beste statistische verwerking daarvan. Desondanks geven de gepresenteerde uitkomsten meer inzicht en daarmee mogelijke aanknopingspunten voor verder onderzoek. 


\section{Inhoudsopgave}

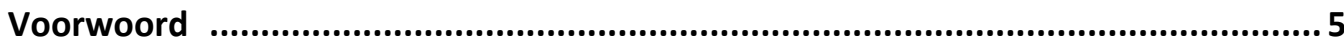

1. Overwegingen en vraagstelling ....................................................................

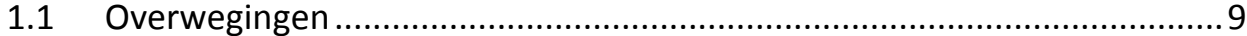

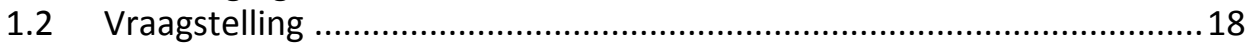

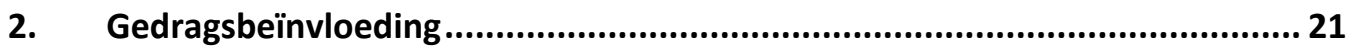

$2.1 \quad$ Een kort historisch perspectief .........................................................2

2.2 Twee decennia onderzoek naar effectiviteit van (gedrags)trainingen .....24

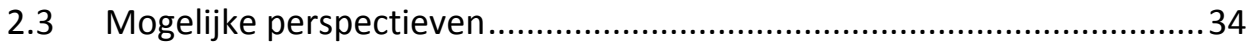

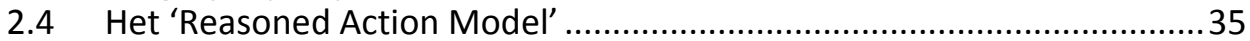

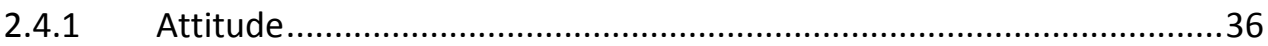

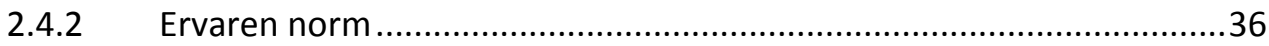

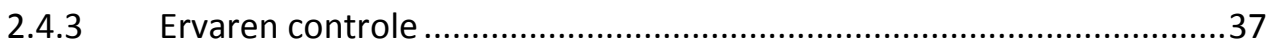

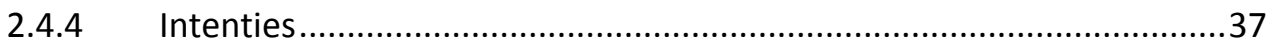

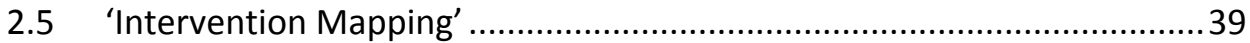

2.6 Een geïntegreerde methode ......................................................... 42

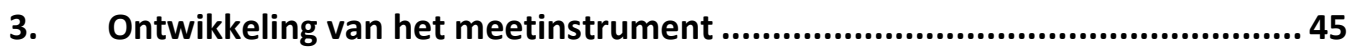

3.1 Uitgangspunten en context .............................................................45

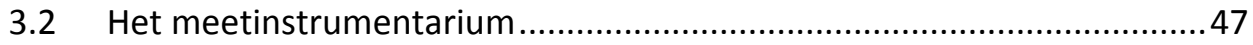



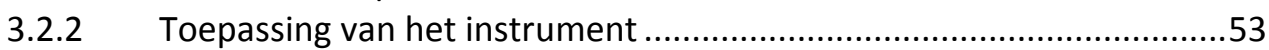

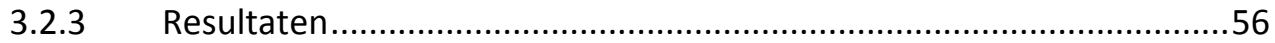

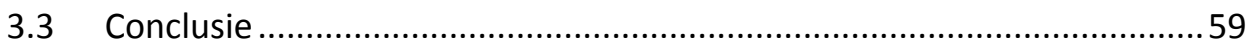

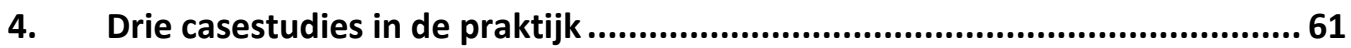

4.1 Inleiding .........................................................................................61

4.2 Casestudie 1: Het productiebedrijf in Nederland $(N=170) \ldots \ldots \ldots \ldots \ldots \ldots . . . .64$

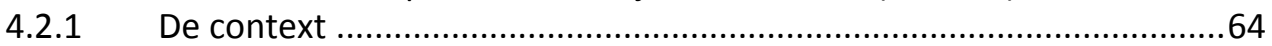

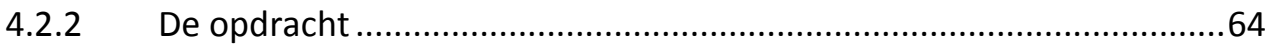

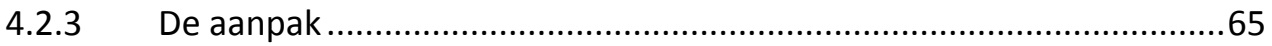

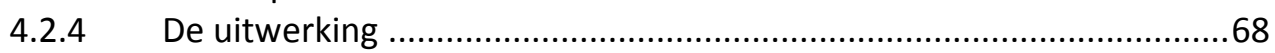



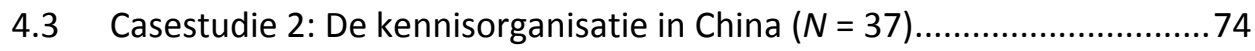

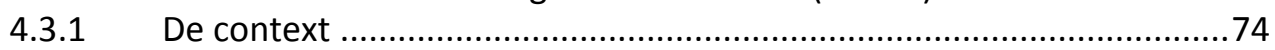

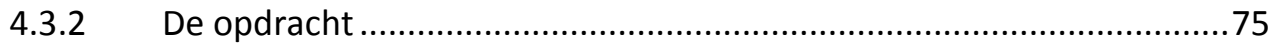

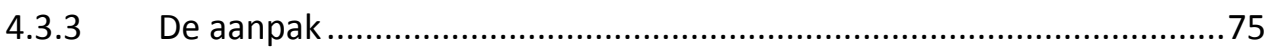

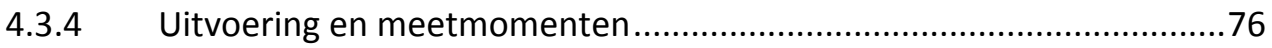



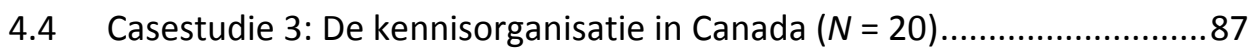

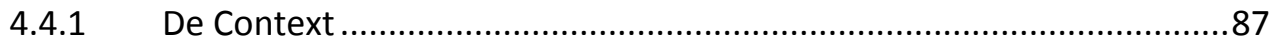

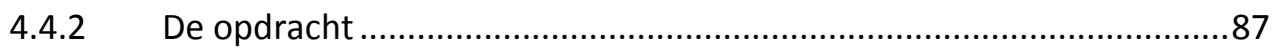

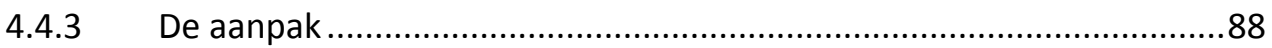

4.4.4 Uitvoering en meetmomenten ......................................................91 


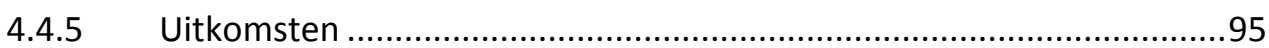

4.5 Resumé van de drie casestudies ................................................. 101

$5 \quad$ Verantwoorde effectmeting zonder controlegroep................................ 105

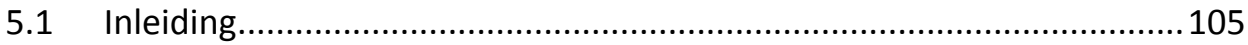



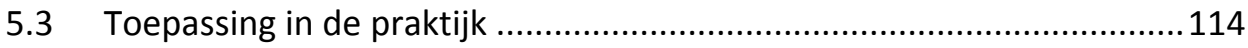

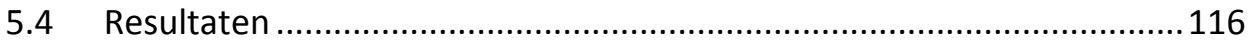

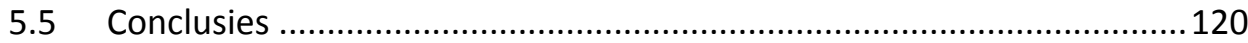

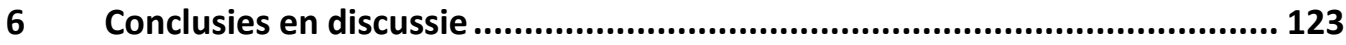

6.1 Conclusies en beperkingen betreffend de deelvragen ...........................124

6.2 Conclusies en beperkingen van het meetinstrument .............................129

6.3 Conclusies en beperkingen in relatie tot de casestudies.......................133

6.4 Conclusies en beperkingen in relatie tot het onderzoek zonder

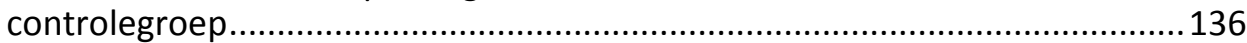

6.5 Aanbevelingen voor verder onderzoek en toepassing in de praktijk .....138

6.5.1 Aanbevelingen voor toekomstig onderzoek.......................................138

6.5.2 Aanbevelingen voor praktische toepassing....................................139

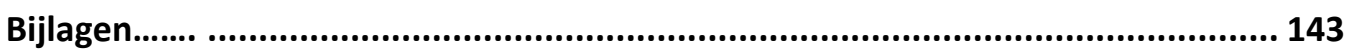

Bijlage 1: Vooropdracht.................................................................... 144



Bijlage 3: Definitieve vragenlijst ........................................................... 147



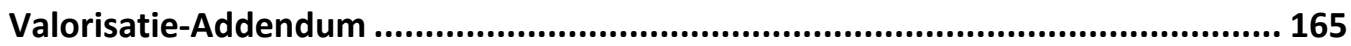

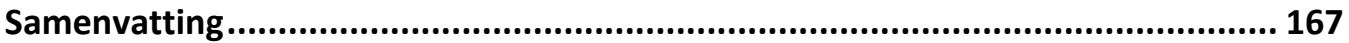

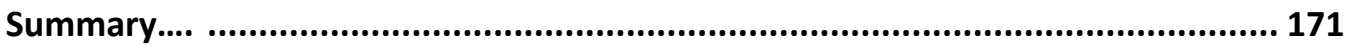

Curriculum Vitae ................................................................................. 175

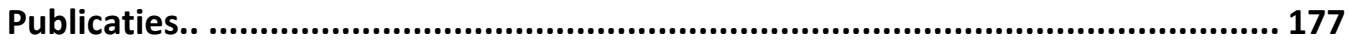



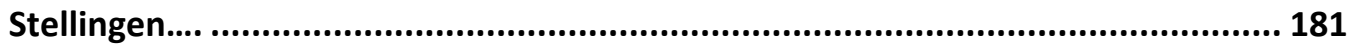




\section{Overwegingen en vraagstelling}

\subsection{Overwegingen}

Interventiestrategieën om het gedrag van medewerkers in organisaties te veranderen, hebben de afgelopen decennia veel aandacht gekregen van (organisatie)psychologen en sociaalwetenschappers. Ook op het gebied van gedragstrainingen in organisaties zijn talloze onderzoeken verricht, omdat veelal wordt aangenomen dat de mens in belangrijke mate invloed heeft op de kwaliteit van bedrijfsprocessen (Dean, Dean \& Reblasy, 1996; Fulmer \& Ployhart, 2014). De generieke uitkomst betrof vaak een model of handreiking voor hoe interventies het beste kunnen worden uitgevoerd. Gedragstrainingen kunnen in dat verband worden opgevat "als oefening, het machtig worden van vaardigheden, het aanleren, verbeteren of veranderen van sociale, cognitieve en psychomotorische vaardigheden" (woordenboek.nl, 2014). Men kan dus veronderstellen, dat het doel van dergelijke gedragstrainingen meestal is om meerwaarde voor de organisatie te creëren of aan de ontwikkeling van de deelnemer zelf een bijdrage te leveren. De effectiviteit van dergelijke trainingen is daarbij volgens Poiesz (1999) voor een groot deel afhankelijk van WAT men wil veranderen (de capaciteit), HOE het geleerde gedrag in de dagelijkse praktijk verankerd wordt (de gelegenheid) en of het uiteindelijk goed gemotiveerd plaatsvindt (de motivatie of het WAAROM). Deze drie afhankelijkheden (wat, hoe en waarom) kunnen worden gezien als de kern van gedragsverandering en bepalen volgens Poiesz (1999) voor een groot deel de uitkomst van gedragstrainingen. Naast het vraagstuk van de effectiviteit van gedragsinterventies (de mate waarin door de interventies ook daadwerkelijk gedragsverandering gerealiseerd wordt) geven onderzoeken naar het rendement van gedragsinterventies een diffuus beeld en zijn onderzoeken naar het verbeteren van het proces van gedragstrainingen minder eenduidig in hun uitkomsten (Russ-Eft \& Preskill, 2005). Rendement kan daarbij worden opgevat als de verhouding tussen kosten die een gedragsinterventie vergen, vergeleken met de opbrengsten daarvan voor mens en organisatie; ook wel "return of investment - ROI" genoemd. Ondanks deze inzichten blijft het in de praktijk moeilijk het beoogde effect van gedragstrainingen te meten, het proces van interventies te verbeteren of de uitkomst daarvan te beïnvloeden (Salas \& Cannon-Bowers, 2001). Bovendien is, mede door de diversiteit wat de aanpak en de interventiemethodes betreft, een vergelijking tussen de diverse (gedrags)trainingen een moeilijke opgave (Aguinis \& Kraiger,2009). Ook is het effect van een interventie mede afhankelijk van de persoon die een training volgt en de omstandigheden waaronder specifiek gedrag wordt vertoond (Poiesz, 1999). Omdat in trainingen het beoogde gedrag in relatie tot de trainingsdoelstelling vaak in algemene termen geformuleerd is (bijvoorbeeld 'resultaatgericht werken' of 'persoonlijke effectiviteit' of 'effectief leiderschap') en omdat de zelfrapportage door de deelnemers als evaluatiemiddel gebruikt wordt, komt de validiteit onder druk te staan. Bovendien zijn de onderzoeksgroepen vaak klein van omvang (een feit waarmee trainingsbureaus juist deelnemers werven), wat een gedegen statistische verwerking belemmert; een probleem dat onder andere ook bij klinische studies veelvuldig wordt beschreven (Wells, 1999).

Naast de problemen in relatie tot het onderzoeksdesign kan ook de opvatting over hoe gedrag in organisaties wordt gerealiseerd, invloed hebben op de gekozen onderzoeksaanpak. Volgens Kluytmans en Bouwen (1998) liggen er in relatie tot gedragsverandering in organisaties drie basale opvattingen ten grondslag. 
De eerste daarvan ziet veranderen als ontwerp of blauwdruk, waarbij regels en structuren een belangrijke rol spelen. Omdat een probleem in een organisatie wordt beschouwd als het resultaat van een verstoring van de ideale structuur, ligt de nadruk bij het veranderingsproces op het ontwerpen van formele structuren volgens voorgeschreven methoden en technieken. Een tweede opvatting over het veranderen van medewerkers binnen organisaties gaat ervan uit, dat het gedrag van mensen zich niet (volledig) door formele structuren en richtlijnen laat beïnvloeden. Daarom wordt het zinvoller geacht, dat men zich bij een gedragsverandering richt op de onderlinge communicatie, de manieren van samenwerken en de implementatie van veranderingen in plaats van veel aandacht te besteden aan procedures en structuren. De derde opvatting kan gezien worden als een integratie van de eerste twee benaderingen. Veranderen wordt dan gezien als een gekozen strategie, waarbij factoren zoals cultuur, zingeving, macht en leeromgeving een belangrijke rol spelen. Bij gedragstrainingen in organisaties is het niet altijd even inzichtelijk over welke verandering het uiteindelijk gaat en welke opvatting daaraan ten grondslag ligt. Het mag duidelijk zijn, dat, met het oog op de complexiteit van gedragsverandering, men zich in het algemeen de vraag zou kunnen stellen, in hoeverre en in welke mate het effect van gedragstrainingen valide kan worden gemeten en gedrag gericht kan worden beïnvloed.

Gezien de geschetste achtergrond is het dan ook niet verwonderlijk, dat het aanbod aan gedragstrainingen immens is en dat er talloze modellen bestaan over hoe gedrag het beste kan worden beïnvloed. Daarentegen is de aanpak (het design) van de meeste gedragstrainingen redelijk vergelijkbaar. Globaal komt het erop neer, dat binnen een beperkte tijd (een aantal dagdelen of uren) door een instrument (trainer/ begeleider, computer, e.d.) kennis en vaardigheden worden overgedragen. Verder worden deze verduidelijkt met behulp van diverse oefeningen, aangevuld met individuele of groepsoefeningen met als uitkomst, dat de deelnemer na de training over nieuwe inzichten en vaardigheden beschikt. Een universeel kenmerk daarbij is dat veel trainingen en interventiemethoden die worden aangeboden, vaak suggereren dat juist deze de beste oplossing voor een specifiek probleem kunnen bieden. In het kader 1.1 is een aantal voorbeelden van dergelijke reclame-uitingen die op internet terug kunnen worden gevonden, weergegeven. Hard 'wetenschappelijk' bewijs voor de gesuggereerde claims is niet overal aanwezig, laat staan dat de effectiviteit van de gekozen proces duidelijk (wetenschappelijk) wordt aangetoond. Veel gedragsaspecten zijn complex van aard, waardoor een specifieke uitkomst moeilijk te meten is. Zoals eerder vermeld is het lastig om complexe en meer algemeen omschreven gedragingen op een eenduidige manier te onderzoeken, zoals het gedrag van goed leiderschap of persoonlijke effectiviteit. Dergelijke begrippen bestaan immers uit talrijke sub-gedragingen en er zou moeten worden gespecifieerd, welk type gedragingen het meest van invloed is op de beoogde uitkomst. In een training 'effectieve communicatie' komen bijvoorbeeld non-verbale communicatie (aankijken, houding, stemvolume), persoonlijke overtuigingen en meer interactieve aspecten aan bod en al deze variabelen zouden stuk voor stuk moeten worden onderzocht. Daarnaast zal voor iedere deelnemer het oordeel over de gevolgde training verschillend zijn, waardoor het waarnemen van specifieke effecten bemoeilijkt wordt. Dit effect wordt door toepassing van zelfrapportage juist versterkt. Bovendien ontbreekt het vaak uit praktische overwegingen aan een controlegroep. 
Kader 1.1

$U$ wilt maximaal resultaat binnen een zo kort mogelijke tijd? En u wilt niet te veel tijd besteden aan de achterliggende theorie, maar direct praktisch aan de slag? Met ons uitgebreide trainingsprogramma behaalt u altijd het gewenste resultaat!

(Vergouwe en Overduin 2014)

Duurzame verandering breng je teweeg vanuit jezelf, of je nou werkt aan je leiderschapskwaliteiten, communicatievaardigheden, je persoonlijke effectiviteit of je kwaliteiten als trainer, coach of adviseur. Via training en/of coaching.

(Van Harte \& Lingsma, 2014)

Kiest $u$ voor een training van de Boertiengroep, dan kiest $u$ voor expertise en kwaliteit. Maar dat niet alleen! We bewijzen dat leren leuk kan zijn!

(Boertien \& partners 2014)

Met ISBW haalt u elke dag weer meer uit uw werk. Niet voor niks gingen vele toporganisaties zoals ... u reeds voor.

(ISBW 2014)

Ondanks deze praktische kanttekeningen met betrekking tot het effect van gedragstrainingen en ondanks de wereldwijde problematische economische ontwikkelingen van de afgelopen jaren, kent Nederland nog steeds een positief klimaat voor opleidingen en trainingen. Het meest recente grootschalige onderzoek door het CBS in 2011 laat onder andere zien dat:

- rond $2 \%$ van de loonsom (dat is ruim $€ 6$ miljard) wordt geïnvesteerd in de individuele ontwikkeling van medewerkers;

- per jaar circa $36 \%$ van de werknemers in een organisatie een vakopleiding volgen; en

- er per jaar ongeveer $€$ 1,6 miljard wordt geïnvesteerd in vakopleidingen, waarbij de talrijke persoonlijke en niet aan het vak gerelateerde opleidingen niet eens zijn meegenomen.

Gezien deze economische waarde zou men kunnen denken, dat de belangstelling juist meer komt te liggen op het verkrijgen van inzichten ter verbetering van het proces en daarmee op het rendement en de effecten van een gekozen interventiestrategie. Voor organisaties zou het van belang kunnen zijn van tevoren een inschatting te kunnen maken van de kosten van opleidingen en de mogelijke opbrengsten daarvan (het rendement) op korte en lange termijn (Lakerveld, Oudendammer \& Stam, 2003). Bovendien lijkt het aantrekkelijk om het gedrag van medewerkers door middel van gerichte interventies zo efficiënt mogelijk in een gewenste richting te kunnen sturen. Kortom, men zou verwachten dat organisaties het belang van goed onderzoek naar de effectiviteit en de procesverbetering van trainingen zouden waarderen. Maar niets blijkt minder waar. Zowel aanbieders als afnemers van trainingen lijken zich er niet van bewust, dat onderzoek naar het rendement weliswaar extra kosten met zich mee kan brengen, maar op termijn juist kostenbesparend kan werken. Alle vernieuwende inzichten op het gebied van gedragstrainingen hebben volgens Salas en Cannon-Bowers (2001) binnen de wereld van gedragstrainingen niet geleid tot grote veranderingen in de inhoud van de aangeboden interventies, noch van de manier waarop deze worden geëvalueerd. Ook wordt door aanbieders en organisaties weinig wetenschappelijk onderzoek uitgevoerd 
naar de randvoorwaarden waaronder het aangeleerde gedrag daadwerkelijk wordt vertoond en wat het resultaat op lange termijn is. Bovendien lijkt een structurele evaluatie van de effecten van gedragstrainingen in organisaties, volgens eigen inzichten, nog steeds tamelijk ongebruikelijk. Coopman et al. (2009) zijn ook van mening, dat de verwachtingen van organisaties ten opzichte van 'een toekomstig evaluatie-instrument weinig realistisch zijn'. Als reden geven zij de uiteenlopende effect- en evaluatiecultuur aan en dat het quasi onmogelijk is een universeel instrument voor evaluatie van trainingen te ontwikkelen.

Salas en Kosarzycki (2003) verklaren waarom organisaties (de afnemers van trainingen) zo weinig gebruikmaken van wetenschappelijke resultaten op het gebied van de gedragstraining:

- Ten eerste hebben organisaties een eenvoudige opvatting over trainingen. In het algemeen komt het erop neer, dat ongetrainde medewerkers naar een training worden gestuurd om vervolgens als gekwalificeerde experts terug te komen. In de praktijk is dit veel complexer en zijn er meer factoren van invloed op de goede uitkomst van een training. Daarnaast zou er exact moeten worden omschreven, wat de uitkomst van een training zou moeten zijn. Dat vereist extra inspanningen die tijd en geld zouden kosten, wat het voor de organisatie minder aantrekkelijk maakt om zich daarmee bezig te houden.

- Ten tweede wordt veelal gedacht, dat trainingen de oplossingen voor nagenoeg alle problemen zijn. Andere factoren zoals de kenmerken van een persoon, de omgeving waarin deze opereert, de kenmerken van de training en de omstandigheden waaronder het geleerde moet worden uitgevoerd en die medebepalend zijn voor het effect van een training, worden buiten beschouwing gelaten. Men gaat uit van een simpel stimulus-response model en denkt niet na over de factoren die mede bepalen of een bepaalde stimulus (de training) leidt tot de gewenste uitkomst.

- Ten derde lukt het veel wetenschappers niet om onderzoeksresultaten te vertalen in concepten die redelijk eenvoudig in de praktijk kunnen worden toegepast. Organisaties zijn vaak beducht voor ingewikkelde theorieën.

- Ten vierde zijn veel onderzoeksresultaten moeilijk toegankelijk voor organisaties en niet wetenschappers. Veel inzichten blijven daardoor onderbelicht en worden niet meegenomen in de dagelijkse praktijk.

- Ten vijfde zou een evaluatie van de effectiviteit van trainingen op lange termijn extra tijd kosten (en dus geld).

Daarnaast wordt het vakgebied van gedragstrainingen als specialistisch ervaren en is het voor de gemiddelde organisatie door de schaalgrootte te duur om zelf trainingen en evaluaties te ontwikkelen. In de praktijk laten dan ook veel organisaties de inhoud, de uitvoering, de keuze voor een specifiek model of specifieke interventiemethode en de evaluatie van een training, en daarmee inzicht in het rendement van een gekozen aanpak, over aan (externe) trainingsbureaus. Het is dan ook niet verwonderlijk, dat aanbieders van (gedrags)trainingen niet of nauwelijks gestructureerd onderzoek naar het behaalde rendement en het effect van interventies uitvoeren (Obdein \& Lubberts, 2013). Een mogelijke reden zou kunnen zijn dat een dergelijke aanpak de kostprijs zou verhogen, dat opdrachtgevers blijkbaar weinig behoefte hebben aan een duidelijk resultaat en dat door onderzoek tevens zou kunnen worden aangetoond, dat de gekozen aanpak uiteindelijk niet effectief is. Het blijft veelal bij een evaluatieformulier, dat aan het einde van een training wordt ingevuld. 
Ook kan worden geconstateerd, dat het onderzoeksterrein erg diffuus en ongestructureerd is, dat aanbieders en afnemers van (gedrags)trainingen en opleidingen ogenschijnlijk weinig aandacht schenken aan de lange-termijneffecten of het rendement van trainingen, terwijl het vanuit economisch standpunt juist wenselijk zou zijn meer inzicht te krijgen in het rendement en de effectiviteit van trainingen.

Ondanks deze terughoudende interesse in de praktijk zijn er in de wetenschappelijke wereld talrijke onderzoeken die zich juist richten op verklarende modellen of theorieën betreffende gedragsverandering en evaluatie. Dat onderzoek gebeurt vaak in een laboratoriumsituatie en vanuit één specifieke onderzoeksvraag. Een kleine inventarisatie levert al snel honderden treffers op. De gepresenteerde mechanismen of processen vertonen daarbij wel onderling grote verschillen. Deze verschillen hebben ook invloed op de wijze waarop onderzoekers en organisaties denken het gedrag van medewerkers te kunnen meten en beïnvloeden (Goldstein \& Ford, 2002). Aanhangers van meer op beloning gerichte benaderingen baseren hun kennis onder andere op straf- en beloningsmechanismen en de sociale leertheorie (Bandura, 1977; 1986). Daarin wordt een relatie gelegd tussen het optreden van specifiek gedrag en de aan dit gedrag gekoppelde beloning, waarbij de omgeving een bevorderende invloed op het uiteindelijke resultaat heeft. Trainingen die dit mechanisme als uitgangpunt nemen, richten zich met name op het aanleren van voorbeeldgedrag. Andere onderzoeken verwijzen in dit verband ook naar het begrip 'self-efficacy', dat refereert aan de mate waarin een persoon verwacht in staat te zijn bepaald gedrag te vertonen. Het betreft een cognitief verwerkingsproces, waarbij het doel en de evaluatie van gewenst gedrag voorop staan (Deci, 1975; Locke \& Latham, 1990), een zienswijze die vooral vanaf de jaren '70 zijn intrede deed bij het ontwikkelen van trainingen in organisaties. Andere onderzoekers richten zich veel meer op de transfer van opleidingen en de daaraan verbonden leercondities (Kirkpatrick, 1975). Daarin is de veronderstelling dat duurzame gedragsverandering pas mogelijk is als mensen het tijdens een training aangeleerde gewenste gedrag daadwerkelijk in de praktijk kunnen toepassen en daarvoor ook nog eens zelf verantwoordelijk zijn (Dewulf, 2003). Ook in de onderwijswereld heeft deze veronderstelling veel aandacht gekregen. Een goed voorbeeld is het onderzoek van De Vries (2003). Hij treft een verband aan tussen leerresultaten, motivatie en eigen verantwoordelijkheid van de leerling binnen het biologieonderwijs op VWO-niveau. Hij pleit er dan ook voor, dat leerlingen vaker worden gevraagd te reflecteren op wat zij hebben geleerd en dat zij daarbij op hun eigen bijdrage (verantwoordelijkheid) worden gewezen.

Een voorbeeld van een bijzonder invloedrijk evaluatiemodel voor studies naar de effectiviteit van opleidingen is dat van Kirkpatrick $(1975 ; 2006)$ en Phillips en Phillips (2007). De veronderstelling is dat evalueren op verschillende niveaus kan plaatsvinden. Op welk niveau geëvalueerd moet worden, hangt af van rol de verzamelde informatie moet spelen. Het model van Kirkpatrick kent vier niveaus van evalueren (zie figuur 1.1). 
Figuur 1.1: Evaluatiemodel van Kirkpatrick (2006): De efficiëntie van opleidingen evalueren
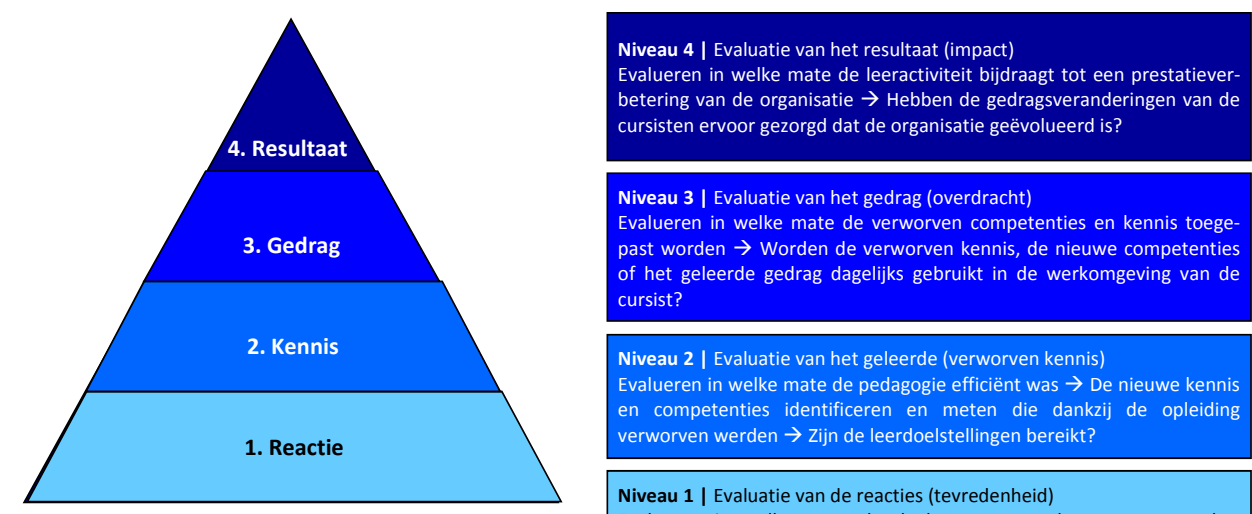

Niveau 2 | Evaluatie van het geleerde (verworven kennis)

Evalueren in welke mate de pedagogie efficiënt was $\rightarrow$ De nieuwe kennis

en competenties identificeren en meten die dankzij de opleiding verworven werden $\rightarrow$ Zijn de leerdoelstellingen bereikt?

Niveau 1 | Evaluatie van de reacties (tevredenheid)

Evalueren in welke mate de deelnemers tevreden waren over het

opleidingsprogramma $\rightarrow$ Een positieve evaluatie veronderstelt niet noodzakelijkerwijs het slagen van een opleiding.

Om de effectiviteit en het rendement van een training te kunnen bepalen, dient een opleiding te worden geëvalueerd op alle vier niveaus (Blanchard, Thacker \& Way, 2000). Hoe hoger het niveau waarop men evalueert, hoe moeilijker het wordt om een directe relatie met de training te leggen en het effect te meten. In de praktijk zijn dan ook niveau 1 (evaluatie na de training) en 2 (afname van een toets) het meest terug te vinden. Naast deze vier evaluatieniveaus van Kirkpatrick gebruiken Phillips en Phillips (2007) een vijfde, dat van de 'return on investment' (ROI). Dit vijfde niveau geeft de financiële impact van de interventie op de bedrijfsresultaten weer. De ROI is een vergelijking tussen de kosten van de leerinterventie en de financiële opbrengsten daarvan voor de organisatie. Hierdoor zijn organisaties gedwongen om ook de kosten/opbrengsten van de training in de evaluatie daarvan op te nemen. Een opgave waartegen slechts weinig organisaties zijn opgewassen. Meestal komen deze niet verder dan evalueren op reactieniveau (Esereyl, 2002), omdat de randvoorwaarden zoals tijd, geld en commitment voor het bepalen van de gewenste oplossingsrichting op organisatorisch niveau ontbreken.

Juist door de veelvoud aan opvattingen en theorieën lijkt het erop, dat organisaties hun medewerkers trainingen laten volgen in de verwachting dat het een positief effect op de prestatie zal hebben zonder dat 'hard bewijs' wordt geleverd. Anderzijds blijft het ook lastig om het effect en het rendement van trainingen/gedragsverandering eenduidig zichtbaar te maken. Zo vergelijken Russ-Eft en Preskill (2005) onderzoeken naar de 'return on investment' van trainingen met de zoektocht naar de heilige graal. Zij concluderen dat een mogelijke oplossing voor dit probleem kan worden geboden door de focus veel meer op de beoogde uitkomsten te richten. Zij bepleiten te onderzoeken of trainingen daadwerkelijk effect opleveren in plaats van of een bepaald model of theorie achter de gekozen aanpak juist is. Zo kan bijvoorbeeld een leerling-lasser die moet leren lassen, na de training aantonen dat hij over de beoogde vaardigheden beschikt of niet. Ook kan het rendement van een dergelijke opleiding (investering in geld en tijd vergeleken met de besparing die het oplevert) worden aangetoond. 
Op het gebied van (gedrags)verandering in organisaties zijn talrijke handboeken te vinden, die de geoefende veranderaar inspiratie moeten geven een gedragsverandering succesvol te begeleiden of te doorstaan (bijvoorbeeld 'Succesvol veranderen' van Jansman \& De Vries, 2011; 'Training Fundamentals' van Fisher-Chan, 2010; 'Leren Veranderen' van Caluwé \& Vermaak, 2006 of 'Handboek Verandermanagement' van Cozijnsen \& Vrakking, 2003). Naast het eenduidig meten van de effectiviteit van een gedragsinterventie is het ook het onderling vergelijken van de interventies zelf een probleem, omdat deze wat achtergrond, design, toepassing e.d. betreft, sterk van elkaar verschillen. Naast een goed toepasbaar meetinstrument zou het ook wenselijk zijn een gestructureerde en uniforme aanpak binnen de gedragstrainingen toe te passen om de impact van gedragsinterventies te kunnen vergelijken. Bij veel gedragsinterventies ontbreekt het aan een zorgvuldige en goed na te trekken beschrijving van het uiteindelijk toegepaste proces. Uitgangspunt bij de ontwikkeling van een meer generieke (protocollaire) aanpak zou het definiëren van een beoogde doelstelling en het daaraan gekoppelde resultaat moeten zijn in plaats van het toetsen van één specifiek (trainings)model of één specifieke theorie. Gedacht wordt aan een probleemgestuurde ordening van stappen, die men doorloopt bij het plannen, ontwikkelen en uitvoeren van interventies. De basis is het definiëren van het probleem, het formuleren van specifieke doelen, het bepalen van methoden en strategieën, het ontwerpen van de gedragsverandering of training en het evalueren van dit proces.

Kort samengevat zouden de volgende vragen steeds op dezelfde manier kunnen worden gesteld:

- Wat is het probleem?

- Welke theoretische en praktische modellen zijn hierover bekend?

- Welke oplossingen zijn reeds onderzocht?

- Welke mogelijke oplossing past bij deze specifieke situatie?

- Hoe wordt de interventie toegepast?

- Wat is het effect daarvan?

Het voordeel van een dergelijke aanpak is, dat de diverse theoretische opvattingen en interventiemethodes naast elkaar kunnen bestaan en de aandacht vooral op de evaluatie van beoogde doelstelling zelf kan worden gericht. Ook wordt een discussie voorkomen over het evaluatieniveau waarop een impact wordt bereikt. Immers, een gemeenschappelijk kenmerk van de diverse theoretische denkkaders is, dat zij de nadruk leggen op de activiteiten die moeten plaatsvinden om gedragsverandering in organisaties door te voeren (Schaffer \& Thomson, 2000). Daardoor komt de nadruk vooral te liggen op het meetbaar maken van het proces, het effect van de gedragsinterventies en van de daarmee beoogde beïnvloeding van (waarneembaar) gedrag. Bovendien kan ook inzichtelijk worden gemaakt welke (rand)voorwaarden aanwezig moeten zijn om gedrag in een gewenste richting te beïnvloeden en daarmee hoe het effect van een interventie vergroot kan worden. Daarnaast wordt iedere interventie daarmee ook voor een groot deel maatwerk in relatie tot de doelgroep, de context en de doorgevoerde interventie.

In tegenstelling tot het bedrijfsleven wordt een dergelijke aanpak veelal in de gezondheidszorg bij gezondheidgerelateerde interventies toegepast. Mede door de stijgende zorgkosten en het immense aanbod aan behandel- en preventietechnieken wordt de nadruk gelegd op onderzoek naar de beste methode voor een beoogde gedragsverandering. 
Willekeurige voorbeelden zijn het effect van een training om de handen te wassen (Brian et al, 2014), van een smartphone-app om lichamelijke activiteit te bevorderen (Glynn et al, 2014), van een op levensgewoontes gebaseerd programma om af te vallen voor volwassenen met diabetes type 2 (Terranova et al, 2015) of van interventies ter bevordering van het tandenpoetsen om plaque te voorkomen (Newton \& Asimakopoulou, 2015). Een van de gemeenschappelijk kenmerken van dergelijke onderzoeken is, dat er een zo duidelijk mogelijke relatie wordt gelegd tussen een specifieke interventie en (relatief) specifiek gedrag, om de relatie tussen interventie en effect zo evident mogelijk aan te kunnen tonen. Zo wordt bijvoorbeeld ook in de geestelijke gezondheidszorg in Nederland sinds enkele jaren ook gebruik gemaakt van de 'Routine Outcome Monitoring' (ROM) (Laane \& Luijk, 2012), een instrument om het effect van behandelingen vast te stellen en te verbeteren, waarvan het rendement juist onder behandelaars ter discussie staat.

Naast de relatie tussen interventie en effect bij een bepaalde ziekte of aandoening wordt binnen de gezondheidszorg ook steeds meer een verband gelegd tussen gezondheid bevorderende programma's en het effect daarvan op een zo groot mogelijke groep. Om het rendement van een dergelijke interventie te kunnen bepalen, wordt daarbij onderzocht in hoeverre de gemaakte inspanning (en daaraan verbonden kosten) zich verhouden tot het behaalde resultaat. Voorbeelden zijn campagnes die als doelstelling hebben bepaald gedrag te bevorderen in relatie tot het stoppen met roken (Nagelhout et al, 2014), veilig vrijen (Khattri, 2015) of gezond eten (Guthrie, Mancino \& Jordan-Lin, 2015). De nadruk wordt daarbij gelegd op het optimaliseren van het proces om gezondheid bevorderend gedrag te stimuleren. Een veelvuldig toepast concept bij dergelijke interventies zijn de principes van "Intervention Mapping"(Bartholomew, Parcel, Kok, Gottlieb \& Fernández, 2011) als basis om interventies te evalueren en het proces (toekomstige interventies) te optimaliseren. "Intervention Mapping' is een raamwerk voor het ontwikkelen van gerichte (gedrags)interventies en bestaat uit een vijftal stappen. Het vormt niet alleen de basis voor een te ontwikkelen interventie, maar kan ook worden gebruikt voor het evalueren van het interventieproces en het effect daarvan op de beoogde doelstelling. Een van de uitvoeringsdoelstellingen is grip te krijgen op het te meten (gedrags)effect. Belangrijk uitgangspunt bij de toepassing van 'Intervention Mapping' is, dat de keuze voor een bepaalde interventie gebaseerd is op empirische gegevens uit de literatuur, bestaande theoretische concepten en te verzamelen gegevens bij de doelgroep.

Geheel in overeenstemming hiermee richt zich dit proefschrift op de optimalisatie van het proces, dat aan de gedragsinterventies in organisaties ten grondslag ligt. Het is daarbij niet de bedoeling zich op één specifieke training, interventie, methode of gedragsvorm te richten, maar het gaat om het inzichtelijk en meetbaar maken van de factoren die effectieve gedragsbeïnvloeding belemmeren of bevorderen, en het meetbaar maken van een beoogde gedragsverandering. Naast inzicht in het effect van een training wordt dan ook inzicht verschaft in het proces en de verbetermogelijkheden daarvan. Het is ook niet de bedoeling een specifiek model of een specifieke theorie in relatie tot de effectiviteit van gedragsinterventies te toetsen. Het betreft de praktische toepassing van principes die het effect van gedragsinterventies bevorderen, binnen een andere context. 
De basis daarbij vormen de uitgangspunten van 'Health Promotion Programs' (Bartholomew et al., 2006) en de in 'Intervention Mapping' toegepaste principes (Bartholomew et.al, 2001). Hierdoor worden de voortgang van een training en het effect van een interventie voor trainer en deelnemer inzichtelijk gemaakt, waardoor naast een meetmoment ook een leereffect wordt gerealiseerd. Tevens is de veronderstelling dat een interventie waarin gericht terugkoppeling wordt gegeven aan de deelnemers (voor, tijdens en na een training) op variabelen die van invloed zijn op het beoogde gedrag, een versterkend effect heeft op het beoogde resultaat en daarmee op het rendement voor de organisatie. De meerwaarde van deze benadering voor de praktijk is, dat er vóór een interventie inzicht wordt gegeven over de belemmerende en bevorderende factoren die van invloed zijn op het gewenste resultaat. De aanname is, dat hierdoor de kans toeneemt dat een methode of interventie wordt gekozen, die beter aansluit bij de behoeften van de doelgroep. Door de deelnemers tijdens de interventie terugkoppeling te geven over deze uitgangspunten en de vorderingen van het proces, wordt er, zo is de veronderstelling, een beter en duurzamer resultaat bereikt. Een dergelijke aanpak stelt organisaties en deelnemers in staat na de interventie stelt deze te evalueren en aan de hand van de aangetroffen resultaten verbeteringen (voor de volgende interventie) door te voeren. Door steeds dezelfde systematiek aan te houden wordt op een gestructureerde manier onderzocht in hoeverre het aan te leren gedrag daarbij verandert, in overeenstemming met de beoogde doelstelling. Naast inzicht, meetbaar maken van de gewenste resultaten en het meten van het effect van gedragsinterventies, wordt hiermee ook de basis gelegd voor een rendementsverhoging.

Een reeds eerder besproken probleem, dat zich bij een dergelijk (praktijk)onderzoek voordoet, is het vraagstuk rondom de validiteit. Ten eerste is bij een training sprake van een niet-werk/praktijkgerelateerde situatie en moet later blijken of de gerealiseerde resultaten (interne validiteit) in de praktijk worden toegepast. Ten tweede is de vraag in hoeverre de ontwikkelde (interventie)methode ook in andere omstandigheden, bij andere doelgroepen resultaten oplevert (externe validiteit). Onder andere Brug et al. (2010) beschrijft deze problematiek binnen het domain van de gezondheidsvoorlichting. In het meest ideale geval wordt een onderzoek uitgevoerd bij grote aantallen deelnemers, met een experiment-controledesign (dubbel blind), over langere tijd en gericht op specifieke gedragingen/vaardigheden. Bij (gedrags)trainingen in organisaties daarentegen is vaak sprake van kleine aantallen deelnemers, het ontbreken van een controlegroep, kortdurende interventies en complexe (diffuse) gedragingen/vaardigheden. In overeenstemming met de door Brug et al. (2010) beschreven problematiek is bij dit onderzoek gekozen voor een ontwikkeling van een methode die rekening houdt met de complexiteit van het beoogde resultaat en de specifieke omstandigheden bij de doelgroep. De uitkomst is een 'halffabricaat' (Brug et al. 2010), dat per situatie moet worden aangepast. Hierdoor zijn de statistische analyses beperkt en heeft bij de toepassing van de ontwikkelde methode (vervolgonderzoeken) steeds meer een verfijning plaatsgevonden, om een evenwicht te vinden tussen de gegeven omstandigheden in de praktijk en goed onderbouwd (wetenschappelijk) onderzoek. 


\subsection{Vraagstelling}

Een belangrijke aanname van dit proefschrift is, dat trainingen/gedragsinterventies gebaseerd op een programma dat zich (voor, tijdens en na de interventie) richt op de factoren die het gewenste gedrag bevorderen of belemmeren, meer effect hebben op het uiteindelijke resultaat van de deelnemers. Bovendien wordt dit effect versterkt, wanneer de betrokkenen ook zelf kunnen kiezen welke interventiemethode of theoretisch model zij willen gebruiken bij de beoogde gedragsverandering. Door een dergelijke aanpak wordt het noodzakelijk de gewenste verandering tastbaar (en meetbaar) te maken. Dit onderzoek richt zich dan ook op het meetbaar maken van gedragsveranderingen en op de procesoptimalisatie van (gedrags)interventies. Procesoptimalisatie wordt daarbij opgevat als het zodanig inrichten van het integratieproces, dat een zo goed mogelijk gewenst resultaat kan worden gerealiseerd. Procesoptimalisatie gaat daarbij veel verder dan alleen het verbeteren van de wijze waarop een activiteit wordt uitgevoerd. Het heeft betrekking op de afstemming en het gebruik van de omgevings- en inrichtingsvariabelen. De veronderstelling is, dat de effectiviteit vergroot wordt door (vooraf) inzicht te krijgen in de factoren die het gewenste gedrag van de doelgroep belemmeren of bevorderen en pas na een analyse daarvan een bij het probleem passende interventiestrategie te kiezen. Door het opsporen van bevorderende en belemmerende factoren en het duidelijk afbakenen van de gewenste doelstelling is er meer rendement, dan wanneer dat niet gebeurt. Daarmee wordt aan betrokkenen een soort 'thermometer' geboden die de voortgang van de gewenste gedragsverandering tastbaar en meetbaar makkt. Door tijdens het interventieproces inzicht te geven over de voortgang van de (gedrags)verandering wordt dit effect versterkt. Dit biedt tevens de mogelijkheid om inzicht te verschaffen in het proces van de verandering en de mogelijkheid dit verder te optimaliseren. De vraagstelling luidt als volgt:

Hoe kan de effectiviteit van gedragsinterventies / trainingen in de praktijk worden gemeten en vergroot en hoe kunnen interventies waarin voor een specifieke aanpak of een specifiek model is gekozen, goed met elkaar worden vergeleken?

Uit deze probleemstelling volgt een aantal deelvragen:

1. Hoe kan de effectiviteit van gedragstrainingen worden gemeten?

2. Welke factoren zijn van invloed op de effectiviteit van gedragstrainingen?

3. Hoe kunnen gedragstrainingen worden geoptimaliseerd?

4. Wat is de invloed van terugkoppeling aan de deelnemers over de factoren die het beoogde resultaat belemmeren of bevorderen?

5. Hoe kunnen interventies op het gebied van gedragsverandering goed met elkaar worden vergeleken?

In dit onderzoek wordt niet een bepaald model of een bepaalde aanpak getoetst, maar wordt een zo gestandaardiseerd mogelijk meetinstrument en een zo gestandaardiseerd mogelijke methode ontwikkeld, waarmee de effectiviteit van gedragstrainingen kan worden gemeten. Daarmee zouden ook diverse onderzoeken in verschillende omgevingen met elkaar kunnen worden vergeleken (hoofdstuk 3 ). Het is daarbij niet van belang, dat voor een specifieke interventiemethode wordt gekozen of specifiek gedrag wordt onderzocht. Hiermee wordt ook een antwoord op probleemstelling 1 en 2 gegeven. Ten tweede is het doel om met een dergelijke methode het proces van trainingen/gedragsinterventies in organisaties te optimaliseren (hoofdstuk 4), waarmee op 
probleemstelling 3 wordt ingegaan. Om deze doelstellingen te realiseren, is, aan de hand van theoretische inzichten en het raadplegen van twee decennia onderzoek naar de effectiviteit van gedragsinterventies, een specifieke methode ontwikkeld, bestaande uit een vragenlijst en een aantal voorgeschreven processtappen. Voor de ontwikkeling van het meetinstrumentarium is gebruik gemaakt van de 'Theory of Planned Behavior' (Ajzen, 1991). Deze theorie veronderstelt dat gedragsvoornemens goede voorspellers zijn voor het uiteindelijke gedrag in de praktijk (Ajzen \& Fishbein, 1980). Later is deze theorie verder uitgewerkt in het 'Reasoned Action Model', de uiteindelijke basis voor de 'Reasoned Action Approach' (Fishbein \& Ajzen, 2010). Om het inzicht in het effect van een gekozen benadering te vergroten en de gekozen interventies met elkaar te kunnen vergelijken, zijn de onderzoeken uitgevoerd gebaseerd op de in "Intervention Mapping" (IM) beschreven principes (Bartholomew et al., 2006; Schaalma et al., 2001). IM staat niet voor één bepaalde aanpak van gedragsverandering, maar is daarbij veel meer een instrument/hulpmiddel waarmee een bewuste keuze kan worden gemaakt uit al bestaande interventiestrategieën, waardoor het beoogde effect kan worden gemeten en de gekozen aanpak gevolgd kan worden (antwoord op probleemstelling 4 en 5). Door de systematische aanpak van IM is het tevens mogelijk de diverse praktijkcases op methode en op effect van de interventie te kunnen vergelijken.

De ontwikkelde methode is in een (praktijk)onderzoek toegepast en is onder gecontroleerde omstandigheden onderzocht (hoofdstuk 3). De gekozen interventies die hebben plaatsgevonden om gedragsverandering bij de specifieke doelgroep te realiseren, waren daarbij minder van belang en waren voor alle deelnemers gelijk. Daarbij is in eerste instantie, samen met de deelnemers, het gedrag dat in relatie staat met het beoogde doel, gedefinieerd en tastbaar (meetbaar) gemaakt. Vervolgens is onderzocht wat de bevorderende of belemmerende invloed is op de beoogde gedragsverandering. De aanname was, dat door deze terugkoppeling voor en na de interventie de gedragsverandering effectiever is. Hiervoor is met behulp van het ontwikkelde meetinstrument aan de deelnemers gerichte terugkoppeling gegeven en kon, door gebruik te maken van meerdere meetmomenten, ook de effectiviteit van de (gedrags)interventies worden gemeten.

Vervolgens zijn het meetinstrument en de methode op een systematische manier in drie uiteenlopende casestudies toegepast (hoofdstuk 4). Alle onderzoeken zijn gericht op specifieke gedragsverandering in organisaties en er is een verband gelegd tussen de doelstelling, de toegepaste interventie en het effect van deze gedragsverandering zelf. In tegenstelling tot andere onderzoeken wordt de nadruk gelegd op het operationaliseren van het gewenste veranderdoel, de gewenste uitkomsten en de daarbij aanwezige stimulerende factoren en aanwezige barrières. Ook is aan de deelnemers terugkoppeling gegeven over deze aspecten en is pas na een eerste analyse een passende interventie gekozen.

Omdat in de praktijk het aantal deelnemers aan een training erg klein bleek te zijn en een controlegroep uit praktische overwegingen niet kon worden geboden, is in hoofdstuk 5 het meetinstrumentarium zo aangepast, dat de toepassing daarvan in de toekomst het mogelijk maakt een effect ook zonder controlegroep wetenschappelijk verantwoord te evalueren. De zogenoemde 'Internal Referencing Strategy' (IRS, Garson, 2008; Haccoun \& Hamtieux, 1994) ook wel bekend als het 'Non Equivalent Dependent Variable Design' (Cook \& Campbell, 1979) biedt namelijk hiervoor een oplossing. 
Met de IRS worden de effecten van een training of interventie vergeleken met gedragsaspecten die juist niet zouden moeten worden beïnvloed. Vooral bij vraagstukken waarbij de groepsomvang een controlegroep niet toelaat, lijkt IRS een goede oplossing.

Afsluitend worden in hoofdstuk 6 de conclusies van alle onderzoeken weergegeven en aanbevelingen voor de praktijk en verder onderzoek uitgewerkt. 


\section{Gedragsbeïnvloeding}

\subsection{Een kort historisch perspectief}

Gedragsverandering is een complex en moeilijk te voorspellen proces. Er bestaan dan ook talloze opvattingen en modellen over hoe gedragsverandering kan worden verklaard, beïnvloed en voorspeld. Bovendien zijn deze opvattingen en modellen afhankelijk van de context waarbinnen deze zijn ontwikkeld (bijvoorbeeld gezondheidszorg, psychologie of organisatiekunde) en van de op dat moment heersende actualiteit binnen de wetenschap. Dit onderzoek richt zich dan ook specifiek op gedragsbeïnvloeding (training) in organisaties. Tot in de eerste helft van de 20e eeuw heerste binnen deze context vooral de opvatting dat gedragsverandering een proces betreft, waarin gedrag door herhaling moet worden aangeleerd en door middel van straf en beloning kan worden versterkt (vooral binnen het behaviorisme). Gedragstrainingen uit deze tijd waren gebaseerd op het 'voordoen-nadoen-belonen'-principe, dat tot op heden nog

Afbeelding 2.1: Leslokaal van de Stichting Willem Smit Historie in Nijmegen (www.willemsmithistorie)



wordt toegepast. De in dit verband wel meest bekende onderzoeker is B.F. Skinner (1948), die de relatie heeft gelegd tussen gewenst gedrag en het 'aanleren' van nieuw gedrag door het systematisch toepassen van straf en beloning. Na uitvoerige dierexperimenten is dit principe van operante conditionering ook toegepast op kinderen. Het uitgangspunt is, dat gedrag kan worden versterkt of verzwakt door er een positief of negatief gevolg aan te verbinden. Historisch gezien werden reeds in de antieke tijd in de sport, krijgskunst of handarbeid deze vormen van gedragstraining toegepast (Driscoll, 2001; Hasaki, 2012), die als voordeel hadden, dat het niet nodig was, dat de participanten konden lezen of schrijven. Later, in de middeleeuwen, is deze aanpak van trainingen verder in het 'meester-gezelprincipe' doorontwikkeld (Schultz \& Schultz, 2006). Het meester-gezelprincipe heeft als uitgangspunt dat de meester over de gewenste vaardigheden beschikt en de leerling deze vaardigheden door afkijken en nadoen leert. Het meester-gezelprincipe is dus kijken en nadoen en gecorrigeerd worden door de meester. Van de leerling wordt verwacht dat deze de vaardigheden leert door deze exact van de meester te kopiëren. Vooral in het handwerk (timmerman, molenaar, smid en schilder) was het heel gewoon dat de leerling bij de meester ging inwonen om alles te leren wat men later in zijn/haar beroep nodig had (Epstein, 1998; Black, 2007), een methode die in de huidige tijd als 'training on the job' wordt gezien en in belangstelling weer toeneemt. 
Ook tijdens de industrialisering (18e eeuw) maakte men van deze principes dankbaar gebruik. In klaslokalen werden werknemers erin getraind hoe zij specifieke handelingen moesten verrichten (zie afbeelding 2.1). Een ander bekend voorbeeld zijn de studies van Frederick Taylor (1856-1915) met zijn 'The Principles of Scientific Management'

Afbeelding 2.2: Productie bij Philips rond 1950 (Ad Smits- Eindhoven in beeld)

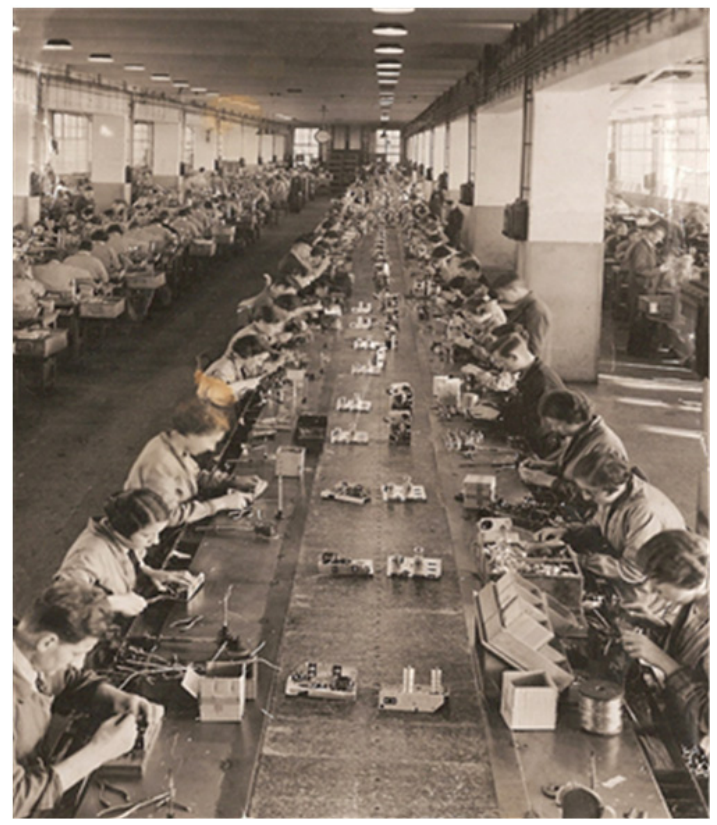

(1911), waarin een optimale match tussen productieproces, machine en werknemer werd nagestreefd. De oorsprong van deze vorm van gedragsverandering had een economische reden: organisaties zochten naar nieuwe mogelijkheden om de productiekosten te verlagen. Taakverdeling, het creëren van gespecialiseerde functies en de optimale match tussen mens en machine stonden voorop. Gewenst gedrag werd beloond met meer salaris met de bedoeling het personeel te motiveren om hogere prestaties te leveren. Om dit te kunnen realiseren zijn gehele werkprocessen minutieus geanalyseerd, gefotografeerd en verbeterd. Leren bestond uit instructie en voorbeeldgedrag, zodat de leerling de handeling exact in zo kort mogelijke tijd kon reproduceren

(zie afbeelding 2.2). Een principe dat ook nog in de huidige tijd bij opleidingen volop wordt toegepast. Sommigen gingen zelfs zover om gedragstrainingen zoveel mogelijk te standaardiseren. Om productiekosten zo laag mogelijk te houden en een zo groot mogelijk productie te kunnen garanderen, maakten de individuele instructies van de leermeester plaats voor systematische of geprogrammeerde leervormen. Deze benadering was tot in de jaren '50 erg populair, waarbij de persoon wel werd vergeleken met een machine die geoptimaliseerd diende te worden.

In de tweede helft van de 20e eeuw ontstond, gebaseerd op de inzichten uit de sociale leerpsychologie, de opvatting dat gedragsverandering mede afhankelijk is van de interactie tussen perso(o)n(en) en de sociale omgeving (zie afbeelding 2.3). Een veel besproken verschijnsel uit die tijd is het Hawthorne-effect (zie kader 2.1) dat refereert aan het effect van een interventie op een onderzochte persoon, dat uitsluitend te wijten is aan het feit dat deze aan het onderzoek meedoet. Door de aandacht van de onderzoeker zouden werknemers meer gaan produceren of minder klachten rapporteren, los van de interventie zelf. Wat trainen van gedrag betreft, zou het betekenen dat puur het volgen van een training al een positief invloed heeft op het gewenste gedrag, een simplistische veronderstelling die door vervolgonderzoeken steeds meer is genuanceerd. Daarbij is ook de definitie van gedragsverandering complexer geworden, om zo met de diverse theoretische invalshoeken rekening te houden. 
Een goed voorbeeld van een dergelijke definitie wordt door Cherrington (1994) gegeven, waarin gedragsverandering wordt gedefinieerd als 'een relatief blijvende verandering van potentieel gedrag als gevolg van oefening in relatie tot de directe omgeving'.

Kader 2.1: Het Hawthorne-effect

Het begrip 'Hawthorne-effect' is door Henry Landsberger (1958) omstreeks 1950 geïntroduceerd. Hij analyseerde vroegere experimenten van de Hawthorne-fabrieken in de buurt van Chicago (Mayo, 1945). In die tijd werd aangenomen dat betere verlichting tot hogere productiviteit zou leiden. Uit de experimenten bleek dat bij productielijnen waarbij betere verlichting was toegepast, de productiviteit daadwerkelijk toenam. Maar in tegenstelling tot de aanname dat gelijkblijvende of zelfs slechte verlichting tot lagere productie zou leiden, kon dat niet worden aangetoond. Ook bij deze productielijnen nam de motivatie en productie van de werknemers toe. De onderzoekers hadden in eerste instantie geen verklaring voor dit effect. Pas Landsberger legde in 1958 een verband tussen de aandacht die werknemers kregen door de aanwezigheid van de onderzoeker en het feit dat zij meededen aan een onderzoek en de toename van de productiviteit. Echter, omdat dit verschijnsel slechts tijdelijk van aard bleek, wordt tegenwoordig de term gebruikt voor elke vorm van kortstondige toename van de productiviteit of de verandering in gedrag vertoond wanneer personen weten dat ze geobserveerd worden. Latere studies trekken de statistische betrouwbaarheid van het onderzoek in twijfel. Ook zijn er studies die aantonen dat aandacht door management juist tot minder productiviteit kan leiden (Bernstein, 2012). Wel is hiermee een grote impuls gegeven aan de groei van en de toenemende interesse in de sociale psychologie en talrijke motivatie studies.

Naast het 'voordoen-nadoen, straf- en belonings' mechanisme is de sociale context waarbinnen gedrag wordt geleerd van invloed op het resultaat (Bandura, 1977; 1986). Trainen wordt in dat geval gezien als een combinatie van de aan het gedrag gekoppelde beloning en de bevorderende invloed van de omgeving op het gewenste gedrag. Trainen en gedragsverandering worden daarmee veel meer een individuele en cognitieve aangelegenheid, waarin personen ook leren door zelf te reflecteren op hun handelen en het behaalde resultaat.
Afbeelding 2.3: Technisch Klaslokaal van de Stichting Willem Smit Historie in Nijmegen (http://www.willemsmithistorie.nl)

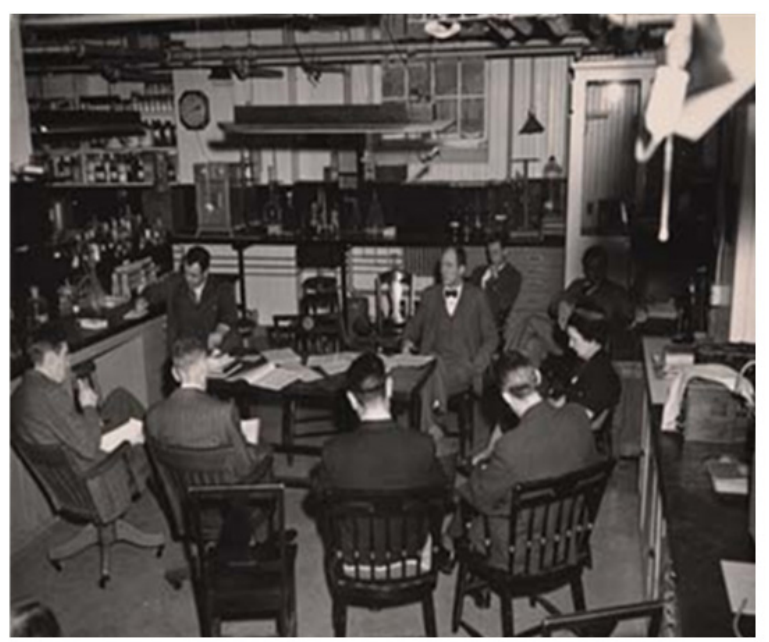


Later wordt in dit verband ook verwezen naar het begrip 'self-efficacy', dat refereert aan de mate waarin een persoon verwacht in staat te zijn bepaald gedrag te vertonen. Anderen spreken liever van een cognitief verwerkingsproces, waarbij het doel en de evaluatie van gewenst gedrag voorop staan (Deci, 1975; Locke \& Latham, 1990). Met name rond 1970 hebben trainingen zich steeds meer gericht op het bieden van inzicht in de eigen vermogens en het effect van het eigen handelen. De harde zakelijke aanpak van gedragsverandering maakt plaats voor sensitivity training, vrije scholen en een toename aan onderzoeken die zich specifiek op groepsinvloeden in relatie tot het individu richten. Naast de sociale invloed op gedragsverandering wordt in recenter onderzoek de aandacht meer gericht op de transfer van opleidingen en de leercondities van trainingen. De veronderstelling is daarbij, dat duurzame gedragsverandering pas mogelijk is als mensen het tijdens een training aangeleerde gedrag daadwerkelijk kunnen toepassen in de praktijk en daarvoor ook zelf verantwoordelijk zijn (Dewulf, 2003) en daardoor bewust gecommitteerd zijn ten aanzien van de gewenste gedragsverandering. Vooral in het onderwijs heeft deze veronderstelling veel aandacht gekregen. Reeds eerder is naar het onderzoek van De Vries (2003) verwezen Waarin hij pleit dat leerlingen vaker wordt gevraagd te reflecteren op wat zij hebben geleerd en waarbij zij tevens op hun eigen bijdrage (verantwoordelijkheid) worden gewezen.

Ook tegenwoordig is de (sociale) psychologie nog volop in beweging, zij het dat er nu veel meer integrale modellen worden ontwikkeld, die gebruik maken van de resultaten en inzichten uit onderzoeken van de afgelopen decennia. Daarin worden diverse opvattingen en bevindingen gecombineerd om specifiek gedrag te verklaren.

\subsection{Twee decennia onderzoek naar effectiviteit van (gedrags)trainingen}

De hoeveelheid theorieën en de eerder beschreven historische ontwikkelingen maken het onderzoek naar gedragsverandering in toenemende mate ingewikkeld, omdat onderzoeken, zowel wat de uitgangspunten als de onderzoeksmethode zelf betreft, fundamenteel van elkaar verschillen. Een gevolg is dat de diversiteit aan onderzoek en de onderzochte variabelen sterk is toegenomen (Thierry et al., 1992). Daarnaast vertonen de aan gedragsverandering gerelateerde verklaringen over de achterliggende mechanismen of processen onderling grote verschillen. Deze verschillen zijn niet alleen van wetenschappelijk belang; zij hebben ook invloed op de wijze waarop men in de praktijk denkt het gedrag van personen te kunnen meten en te beïnvloeden (Goldstein \& Ford, 2001). Volgens Salas en Cannon-Bowers (2001) hebben deze zienswijzen tot een immense groei van onderzoek naar gedragstrainingen geleid, mede ingegeven door het feit dat in organisaties het bewustzijn is ontstaan, dat trainingen een verantwoorde investering moeten zijn. $\mathrm{Er}$ is dan ook meer informatie dan ooit beschikbaar betreffende theorieën, modellen, empirische resultaten en onderzoeken over (gedrags)trainingen.

\section{Salas en Cannon-Bowers}

In hun review geven Salas en Cannon-Bowers (2001) een goed overzicht van de ontwikkelingen binnen het onderzoek naar trainingen. Zij merken op, dat onderzoek zich steeds meer richt op deelaspecten binnen de trainingsomgeving en beschrijven in hun review vijf ontwikkelingen:

1. toetsing van bepaalde concepten, modellen of theorieën;

2. onderzoeken naar de condities binnen een organisatie waaronder interventies plaatsvinden (omgeving); 
3. de condities waarbinnen een training/interventie plaatsvindt;

4. specifieke trainingsmethoden en/of instructies; en

5. de post training condities (of transfer).

Ad 1: Allereerst constateren zij dat de theoretische ontwikkelingen, gericht op concepten en verklaringen voor gedragsverandering ('hoe werkt een bepaalde training/interventie?') zijn toegenomen. Niet alleen de toegenomen aandacht naar gedragsverandering en trainingen in het algemeen, maar vooral de beschikbaarheid aan data, concepten en evaluatiemethoden heeft volgens hen ertoe bijgedragen, dat onderzoek naar theoretische concepten wetenschappelijk steeds beter wordt onderbouwd. Opvallend daarbij is wel, dat het erop lijkt dat de concepten en theorieën in de loop van de tijd steeds complexer zijn geworden, deels door concepten te integreren of door het aantal facetten die van invloed zijn op gedragsverandering, uit te breiden. Zij worden vaak als integrale concepten gepresenteerd (Tannenbaum et al., 1993), die alle stadia van een trainingsinterventie (presituatie, interventie en postsituatie) in een analyse meenemen. Naast de uitgangsposities voor een succesvolle interventie wordt daarbij ook gekeken naar organisatieinvloeden, de trainingsmethode zelf of de transfer van kennis en gedrag en de evaluatie daarvan.

Een andere ontwikkeling is, dat situationele aspecten en vooral de barrières die de gedragsverandering in de weg staan aan belangstelling toenemen. Een goed voorbeeld van deze ontwikkeling is in het dynamisch oriëntatiemodel van Coopman et al. (2009) terug te vinden, waarin een aantal evaluatiemodellen geïntegreerd worden (figuur 2.4).

Figuur 2.4: Het dynamisch oriëntatiemodel (Coopman et al., 2009)

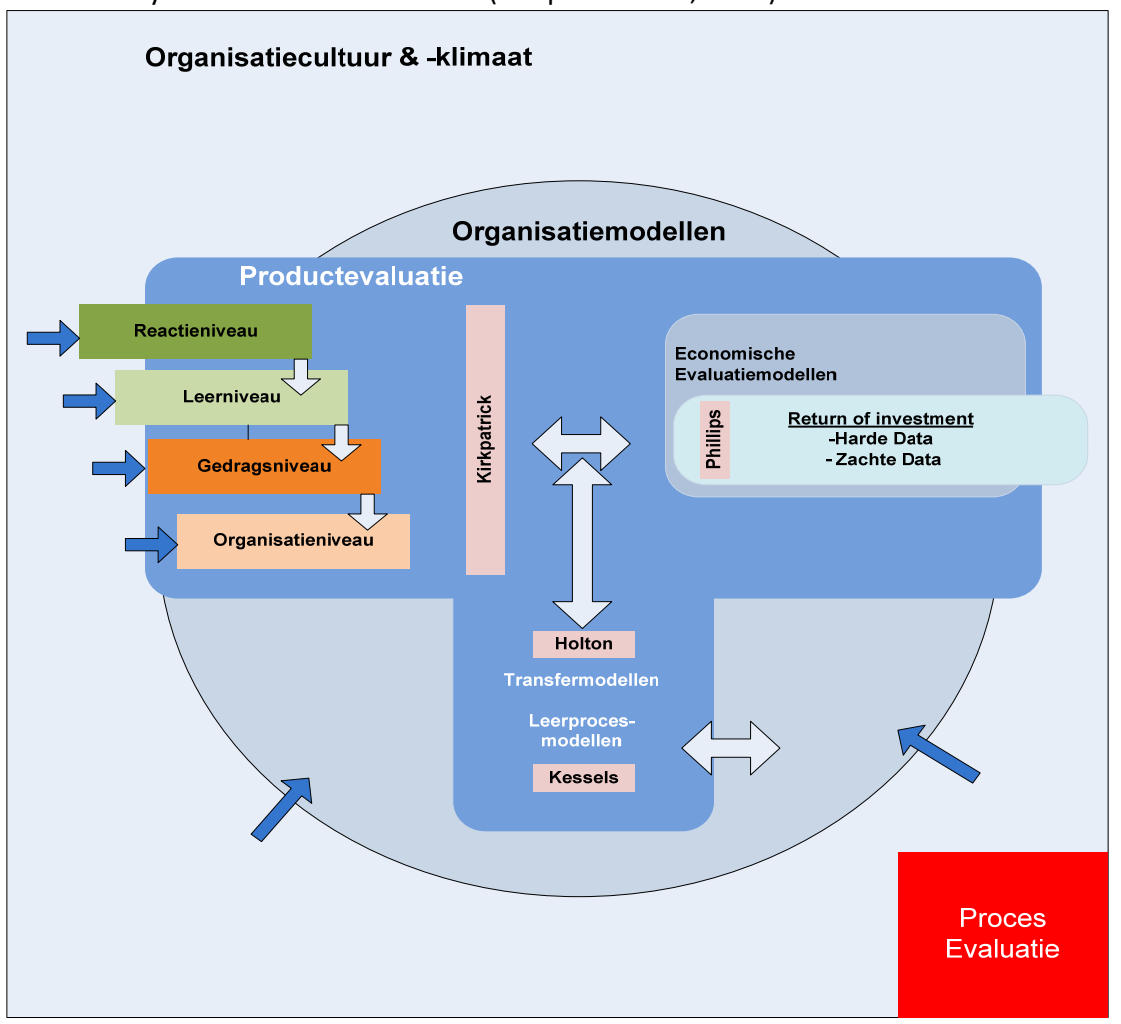


Het uitgangspunt van dit model is, dat het effect van een interventie op verschillende niveaus gemeten kan worden (namelijk reactie-, leer-, gedrags-, organisatie- en economisch niveau) en dat bij de evaluatie met deze niveaus afzonderlijk rekening moet worden gehouden. In feite worden hierin vier theoretische concepten over leren tot één model samengevoegd. Het voordeel van deze ontwikkeling is, dat door deze holistische aanpak recht wordt gedaan aan de feitelijke situatie in het veld. Anderzijds dreigen dergelijke concepten daardoor ook te complex te worden, waardoor de praktische meerwaarde wordt verminderd en de toepasbaarheid in de praktijk wordt belemmerd. Recente onderzoekers kijken dan ook naar het proces van een specifieke (leer) interventie en maken gebruik van inzichten van de diverse 'best-practices' (Obdeijn \& Lubberts, 2013).

Ad 2: Naast de theoretische ontwikkelingen constateren Salas en Cannon-Bowers, dat ook de aandacht voor een betere organisatieanalyse is toegenomen. Daarin worden de werk- en tabak-gerelateerde condities onderzocht waaronder bepaalde resultaten kunnen worden behaalden bijgestuurd ('onder welke organisatie gebonden condities werkt de training / interventie het best?'). Bij dit type onderzoeken wordt vooral naar het proces en de context waarbinnen een interventie plaatsvindt, gekeken. De veronderstelling is dat een trainingsprogramma aan moet sluiten bij de doelstellingen van de organisatie en bij de context waarbinnen het geleerde moet worden toegepast (Goldstein, 1993). Daarnaast zijn er talloze onderzoeken die zich richten op een optimale aansluiting tussen trainingsinhoud en taakinhoud op het werk (onder andere Arvey et al., 1992 of Wilson \& Zalewski, 1994). In die zin lijken deze onderzoeken aan te sluiten bij traditie van 'scientific management', waarin een optimale connectie tussen mens en taak wordt gerealiseerd. Nieuw is wel, dat er veel meer met de cognitieve aspecten rekening wordt gehouden. Zo richten onderzoeken van onder andere Ford (1993) zich meer op de ervaring en op meer persoonsgebonden factoren in relatie tot de verwachtingen op meerwaarde van een training. Daarbij wordt een relatie gelegd tussen individuele leerbehoeften en de in een training geboden instrumenten.

Ad 3: Een derde aspect waarop zich onderzoeken naar trainingen richten, zijn volgens Salas en Cannon-Bowers de trainingscondities. Hierbij staan eigenschappen van de persoon zelf of motivatie om een training te volgen voorop. Zo blijken cognitieve verwerkingsprocessen en ervaringen uit eerdere trainingen van invloed te zijn op de uitkomst van een interventie. Vooral de vaardigheid om een trainingssituatie op de eigen werksituatie te kunnen betrekken, is een goede voorspeller voor het positieve effect van een interventie (Tannenbaum et al., 1993). Andere verwijzen eerder naar het begrip 'selfefficacy' dat een goede voorspeller lijkt te zijn voor het effect van een training (Salas \& Canon-Bowers, 2001 p. 478). Maar ook doelgerichtheid en of de motivatie om een bepaalde training te willen volgen, verklaren voor een groot deel het effect van een interventie ('wat heeft de meeste invloed op de participanten?'). Verder zijn er talrijke onderzoeken die zich op de invloed van de pre-training condities richten. Het betreft de variabelen die een deelnemer stimuleren om nieuwe activiteiten te ontplooien en die bepalen hoe een training zo kan worden ingericht, dat maximaal rendement wordt behaald.

De belangrijkste uitkomsten van deze onderzoeken zijn dat de cognitieve vaardigheden van een individu een goede voorspeller zijn voor de transfer van trainingsactiviteiten (Ree et al., 1995). Het gaat vooral om een duidelijke doelstelling en de link tussen trainingsdoelen en de praktijk. 
De overtuiging van een persoon een nieuwe taak of handeling in de toekomst ook daadwerkelijk te kunnen voeren (self-efficacy), blijkt een goede voorspeller.Een goed voorbeeld over het concept 'self-efficacy' wordt door Gist en Mitchell (1992) weergegeven. In hun artikel geven zij aan niet alleen een positieve verwachting over een te behalen resultaat de uiteindelijke uitkomst beïnvloedt, maar ook de taak zelf, persoonlijke omstandigheden en eerdere ervaringen (figuur 2.5). Een duidelijke doelstelling over het te behalen resultaat en de motivatie (positieve houding ten opzichte van een training) zijn daarbij bevorderende factoren.

Figuur 2.5: Het model van Gist \& Mitchell

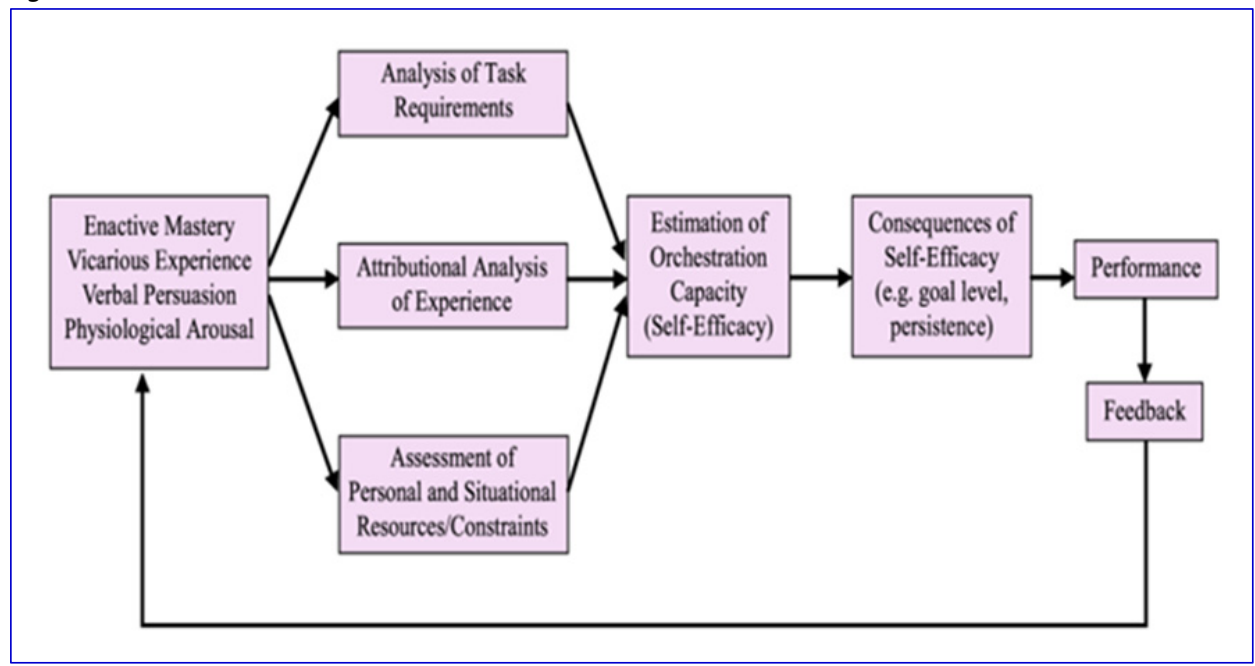

Ad 4: Als vierde terrein beschrijven Salas en Cannon-Bowers de ontwikkelingen van onderzoek naar specifieke trainingsmethoden en -instructies. Deze richten zich met name op leeraanpak, de gegeven leertechnieken, de technologische ondersteuning en simulaties ('op welke manier kan het trainingsproces worden gefaciliteerd?'). Zo lijken trainingsopbouw, herhaling van oefeningen, duur van een training en de taak zelf van invloed te zijn op het effect van een interventie (waaronder Driskell et al., 1992). Naast het type training (individueel, groep, op afstand, e.d.) blijken ook feedback, trainingsintervallen en de leeromgeving van invloed op het resultaat van een interventie. Verder treffen Salas en Cannon-Bowers onderzoeksresultaten aan die aantonen, dat simulaties en spelsituaties een positieve invloed hebben op het effect van een training. Daarnaast is aangetoond, dat trainingen in een team en dus met andere personen die zich in een vergelijkbare uitgangspositie bevinden, een positieve invloed op het leerrendement hebben (Cannon-Bowers \& Salas 1998). Een aantal onderzoekers hebben zich specifiek gericht op het ontwikkelen van trainingsprotocollen om zo het rendement te verhogen (Arthur et al., 1997).Verder concluderen Salas en Cannon-Bowers, dat met de verdere technologische ontwikkelingen ook de aandacht uitgaat naar computerondersteunde interventies en spelsituaties, waarin ook moeilijke praktijksituaties (bijvoorbeeld in een vliegsimulator) op een veilige manier geoefend kunnen worden.

Vooral de onderzoeken van Helmreich (1993/1999) laten zien, dat computerondersteunde trainingen een positief resultaat opleveren betreffende teamsamenwerking en probleemoplossend vermogen van vliegtuigcrews. 
Ook Salas en Cannon-Bowers zelf (2001) verrichten veel onderzoek naar effectiviteit van teamtrainingen en concluderen dat er betere onderzoeksprotocollen moeten worden ontwikkeld om de aanwezige kennis gemakkelijker te kunnen delen.

Ad 5: Het vijfde onderzoeksgebied dat Salas en Cannon-Bowers in hun review beschrijven, heeft betrekking op de posttraining condities, waarbij de evaluatie van het effect en de transfer van de training centraal staan ('wat zijn de effecten van de training/interventie op langere termijn?'). De meest bekende onderzoeken op dit gebied zijn die van Kirkpatrick en collega's (2006) over hun evaluatiemodel. Dit model beschrijft vijf niveaus van evalueren van trainingen. Phillips (2007) heeft aan dit model het vijfde niveau toegevoegd (zie figuur 2.6). Dit niveau (ROI, return on investment) verbindt geldelijke waarde aan Kirkpatrick's resultatenniveau en corrigeert dit vervolgens met de kosten van de training. Op het eerste niveau, het 'reactieniveau' wordt de subjectieve tevredenheid van de deelnemers aan een training geëvalueerd. Het betreft vaak een aantal vragen over de tevredenheid van de deelnemer over de gevolgde training. Op het tweede niveau, het 'leerniveau', wordt gekeken/gemeten of de deelnemers aan de training de aangeleerde kennis, vaardigheden of attitudes verworven hebben. In de praktijk betreft het bijvoorbeeld de terugkoppeling aan de direct leidinggevende of collega over de inhoud van de training. Er wordt op dit niveau nog niet nagegaan of dit ook wordt toegepast in de werksituatie. Van een productevaluatie of effectmeting is er dus nog geen sprake. Bij het derde niveau, het 'werkgedragniveau' wordt geëvalueerd of de deelnemer het geleerde ook kan toepassen in de eigen werksituatie. Een mogelijkheid om dit te doen, is bijvoorbeeld door de medewerkers te observeren, door praktijkexamens of aan de hand van interviews. Een bijkomende moeilijkheid hierbij houdt verband met het feit dat het niet duidelijk is of de eventuele gedragsverandering ook werkelijk toe te schrijven is aan de gevolgde training. Bij het vierde niveau, het 'organisatieniveau', wordt nagegaann of de training ook een bijdrage heeft geleverd tot de realisatie van de doelstellingen van de organisatie, in de praktijk een moeilijke opgave.

Figuur 2.6: Evaluatiemodel van leerinterventies volgens Phillips

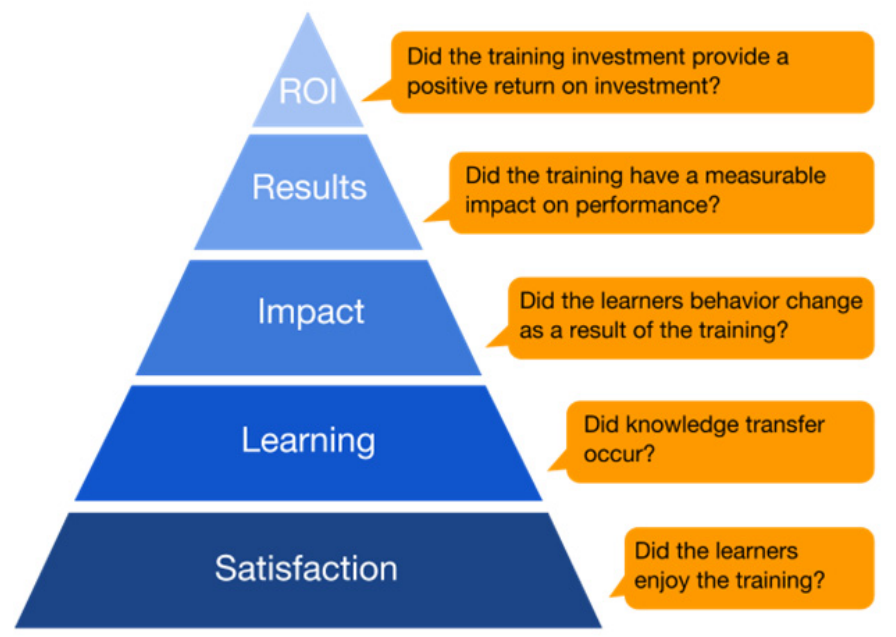


Op het model van Kirkpatrick zijn talrijke varianten ontwikkeld en vooral het vijfde niveau - dat van de Return Of Investment - wordt door Russ-Erft en Preskill (2005) dan ook vergeleken met de zoektocht naar de heilige graal. Salas en Cannon-Bowers geven aan, dat dit type onderzoeken zich vooral richt op de toepassing van het geleerde na een interventie, en zij leggen een directe relatie met het effect en rendement van een training. Het begrip 'transfer' wordt daarbij veelvuldig gebruikt en verwijst naar de mate waarin personen in hun dagelijks doen gebruik maken van hetgeen zij in een opleidingssituatie hebben geleerd. Ook wordt naar de invloed van de omstandigheden verwezen, waarbinnen aangeleerd gedrag plaatsvindt. In de lijn van de onderzoeken van Tannenbaum et al. $(1992 ; 1993)$ concluderen Salas en Cannon-Bowers dan ook, dat de leeromgeving binnen een organisatie, de tijdspanne tussen interventie en toepassing, de sociale context (collega's), het type leiderschap en de ondersteuning op de werkvloer van invloed zijn op de lange-termijneffecten van een training.

Salas en Cannon-Bowers concluderen, dat er op dit moment meer theorieën, modellen en empirische resultaten beschikbaar zijn dan ooit tevoren, terwijl tegelijkertijd de vergelijkbaarheid van de diverse onderzoeken is afgenomen. Wel zijn zowel kwaliteit als kwantiteit van de onderzoeken sterk toegenomen en is het onderzoeksterrein steeds meer multidisciplinair geworden. Verder hebben technologische ontwikkelingen (waaronder de computer) hun invloed op de manier waarop trainingen worden ingericht. Het onderscheid tussen effectiviteit en evaluatie is toegenomen en de aandacht richt zich steeds meer op een optimale aansluiting tussen training en daadwerkelijke werksituatie. Zo blijken de trainingen die aansluiten bij de werkpraktijk, meer effect te behalen en daardoor meer rendement voor de organisatie. Een uitkomst die ook door andere onderzoeken wordt bevestigd (Dean et al.,1996; Kluitmans \& Bouwen, 1998; Obdein \& Lubberts, 2013; Poisz, 1999). Ook meer aandacht voor de leerbehoefte en leerhouding (motivatie) kunnen betere effecten behalen (Dewulf, 2003). Verder blijkt het trainingsdesign waarbij in een groep wordt gewerkt, direct feedback wordt gegeven en rekening wordt gehouden met de culturele omstandigheden (Helmreich \& Merrit, 2001), een positieve invloed op de uitkomst te hebben. Trainingen waarbij integraal wordt gekeken naar uitgangspositie, de training zelf en de transfer in de praktijk,blijken het meest positieve effect op het resultaat te hebben. Zo vonden Velada et al. (2007) in hun onderzoek aanwijzingen dat aandacht voor het inrichten van de transfer, self-efficacy van de deelnemer, programmering (herhaling) van de training en terugkoppeling over de resultaten aan de deelnemers een significante invloed hebben op de transfer van de in de training opgedane kennis en vaardigheden naar de praktijksituatie. Ook toont het onderzoek van Pham, Segers en Gijselaers (2013) naar de transfer bij een masteropleiding aan, dat factoren zoals ondersteuning door de direct leidinggevende, taakautonomie en sterk op het individu gerichte de transfer (en dus het rendement) van een opleiding verhogen.

Ondanks deze positieve uitkomsten betwijfelen Salas en Cannon-Bowers sterk of de aanwezige kennis dan ook daadwerkelijk invloed heeft op de aanpak van trainingen in organisaties. In de praktijk veranderen deze nauwelijks, wat de auteurs doet concluderen, dat de praktijk onvoldoende gebruik maakt van de inmiddels aanwezige kennis en ervaring. Hierdoor wordt het niet alleen moeilijker om de diverse onderzoeken met elkaar te vergelijken, maar men zou ook kunnen veronderstellen, dat de wetenschappelijke diepgang op een specifiek terrein wordt gemist. Zij benadrukken dat toekomstig onderzoek zich meer zou moeten richten op de praktische toepassing van aanwezige kennis en onderzoeksresultaten (Salas \& Cannon-Bowers, 2001). 


\begin{abstract}
Aguinis en Kraiger
In vervolg op de review van Salas en Cannon-Bowers (2001) hebben Aguinis en Kraiger (2009) een groot aantal onderzoeken naar de opbrengst van trainingen voor individuen, teams, organisaties en maatschappij van de afgelopen 10 jaar in kaart gebracht. Na bestudering van meer dan 600 artikelen, boeken en tijdschriften brengen zij meer verbreding aan door zich niet zozeer op de theoretische deelaspecten van onderzoek op het rendement van trainingen te richten, zoals eerdere auteurs dat hebben gedaan. Zij willen vooral de inzichten weergeven hoe een training kan worden ingericht, uitgevoerd en geëvalueerd, zodat maximaal rendement wordt behaald. Ook zij steunen een multidisciplinaire aanpak en het gebruik van aanwezige kennis om fragmentatie op de diverse onderzoeksterreinen tegen te gaan. Juist omdat voor een 'return of investment' een verschil bestaat tussen het effect van een interventie en het rendement daarvan voor de organisatie, maken zij bij de beschrijving van hun uitkomsten een onderscheid tussen:

1. onderzoeken naar de meerwaarde van de trainingsactiviteiten zelf; en

2. onderzoeken naar hoe het rendement kan worden gemaximaliseerd.
\end{abstract}

Ad 1: De onderzoeken naar meerwaarde van trainingen laten zich grofweg in drie deelgebieden verdelen: de personen, de organisatie en de maatschappij. Wat de meerwaarde voor personen betreft, wordt in diverse onderzoeken aangetoond, dat het volgen van een training een positieve invloed heeft op het aan de training gerelateerd gedrag en prestatie. De meest effectieve trainingen richten zich daarbij op een aanpak van de cognitieve en interpersoonlijke vaardigheden (Arthur et al., 2003). Trainingen die een sterke relatie leggen tussen trainingssituatie en praktijk (bijvoorbeeld training 'on the job') leiden tot een positievere uitkomst dan trainingen die dat minder doen. Ook is duidelijk geworden, dat het leren met gedragsvoorbeelden (Barber, 2004; Taylor et al., 2005) en trainingen waarin ook inzicht is gegeven in het 'waarom', het beste rendement opleveren. In dat verband verwijzen zij onder andere naar een onderzoek van Frayne en Geringer (2000), waarin een duidelijke relatie wordt gelegd tussen de trainingsinhoud en de verwachting van een individu, dat deze in de toekomst het geleerde daadwerkelijk gaat toepassen ('self-efficacy' en 'outcome-expectancy'). Daarnaast zijn er andere factoren waaronder tijd, context, culturele verschillen en sociale invloeden, die de uitkomsten van een training kunnen beïnvloeden. Deze uitkomsten worden ook bij onderzoeken naar groepstrainingen gevonden.

Wat de meerwaarde voor de organisatie betreft, is het aantal onderzoeken duidelijk geringer. In minder dan $5 \%$ van de gevallen wordt een link gelegd tussen training en de financiële meerwaarde voor de organisatie. Zo noemen zij als voorbeeld het onderzoek van Aragón-Sánchez et al. (2003), waarin een positief verband wordt gevonden tussen in-company trainingen en de effectiviteit en de financiële meerwaarde van een interventie voor de organisatie. Ondanks deze positieve uitkomsten concluderen AragónSánchez et al. (2003), dat organisaties te weinig investeren in training en de evaluatie daarvan. Verder vermelden Aguinis en Kraiger diverse onderzoeken die een positieve relatie leggen tussen werknemerstevredenheid, klanttevredenheid en productiviteit door het volgen van trainingen. Daarnaast komt uit een onderzoek in diverse Europese landen (Mabey \& Ramirez, 2005) naar voren, dat er een positieve relatie bestaat tussen management-developmentprogramma's en de financiële performance van een organisatie. 
In zijn totaliteit treffen Aguinis en Kraiger (2009) onderzoeksresultaten aan, die laten zien dat de meerwaarde van een training afhankelijk is van de kwaliteit van de training zelf, de omstandigheden waaronder wordt getraind, de trainingsinhoud en de manier waarop effecten gemeten worden.

Met betrekking tot de toegevoegde waarde van trainingen voor de maatschappij is er

Figuur 2.7: Het IIP model

(http://www.investorsinpeople.co.uk)

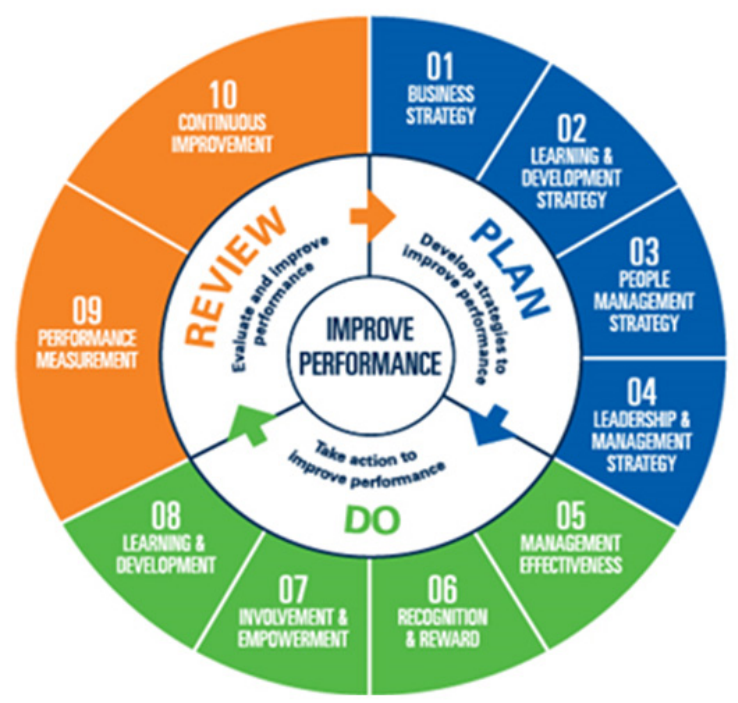

een duidelijk verband tussen trainingsinspanningen in relatie tot het versterken van de kwaliteit van de werknemers en de groei van de nationale economische waarde. Daarbij hoeft het verband niet altijd één op één gerelateerd te zijn (hoe meer trainingen hoe meer economische groei). In GrootBrittannië bijvoorbeeld is in tijden van crisis met het ' $I n$ vestors in People'-certificaat (figuur 2.7) het initiatief genomen om zonder meerkosten een hoger rendement uit trainingsactiviteiten te realiseren door beter aan te sluiten bij de behoefte van organisatie en medewerker (Al-

berga, Tyson \& Parsons,1997). Een initiatief dat later ook in Nederland is omarmd.

Ad 2: Op basis van de vergelijking van de onderzoeksresultaten naar maximalisatie van het rendement van trainingen hebben Aguinis en Kraiger (2009) onderzoeken aangetroffen die laten zien dat trainingsprogramma's waarin vooraf een probleemanalyse heeft plaatsgevonden, duidelijk meer rendement opleveren (Blanchard \& Thacker, 2007). Daarbij wordt de aanbeveling gedaan om gebruik te maken van inhoudsexperts, personen die inhoudelijk en ervaringsdeskundig zijn. Vooral het betrekken van de werkvloer en het management bij de beoogde aanpak heeft een positieve invloed op het trainingsresultaat. In dat verband verwijzen zij naar een onderzoek van Tracey et al. (2001) die een positieve relatie leggen tussen de pre-training motivatie en het rendement van een training. Door vóór een training de aandacht te richten op individuele leerbehoefte en de problemen in de praktijk groeit de verwachting over de bijdrage van een training bij de deelnemers. Daarmee wordt het zelfbewustzijn van de deelnemers verhoogd en groeit het vertrouwen van de deelnemers, dat zij de geleerde kennis en vaardigheden in de praktijk daadwerkelijk kunnen toepassen. Bovendien dwingt het de organisatie, naast het duidelijk definiëren van het probleem, ook tot de keuze van een 'evidence based' aanpak. Andere onderzoeksresultaten maken duidelijk, dat ook het ontwerp en het instrumentarium van een training van invloed zijn op het uiteindelijke resultaat. Daarbij lijkt systemisch leren een positieve invloed te hebben op langetermijnresultaten van trainingen (Linou \& Kontogiannis,2004). Wat het ontwerp betreft, lijkt een combinatie tussen kennis en de toepassing daarvan in de praktijk, gecombineerd met ervaringsgericht ('error management training') leren, het rendement 
van een training te maximaliseren (figuur 2.8; Aguinis \& Kraiger, 2009). Ook in dat verband wordt in onderzoeken het begrip 'transfer' of 'overdracht' veelvuldig gebruikt. Deze onderzoeken richten zich met name op de wijze waarop nieuwe kennis en vaardigheden in de praktijk worden toegepast. Met andere woorden, als na een training het gedrag in de praktijk is veranderd, is er sprake van daadwerkelijke overdracht en kan een uitspraak worden gedaan over het rendement van een interventie

Figuur 2.8: Aguinis en Kraiger (2009)

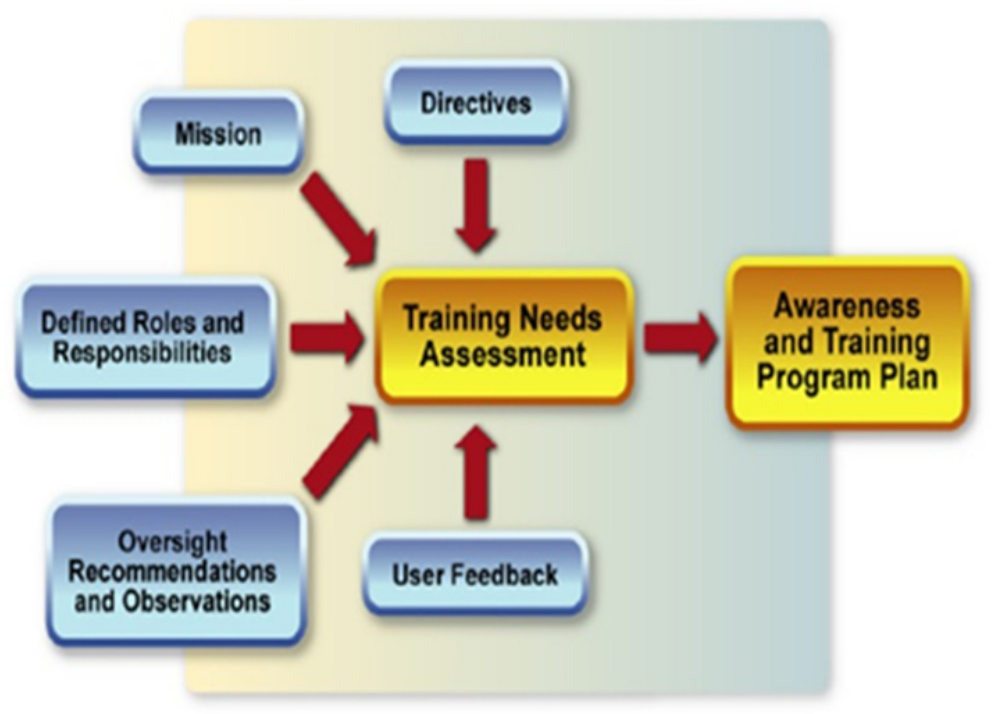

Globaal tonen onderzoeken die zich specifiek richten op de overdracht, aan dat het succes daarvan afhankelijk is van persoonsfactoren (waaronder 'self-efficacy'), motivatie ('outcome expactations'), werkomgeving (directe collega's en leidinggevende) en de mogelijkheid om het geleerde toe te kunnen passen (Holton et al., 2003). Zo vond Kontoghiorghes (2004) dat werkklimaat en omstandigheden een goede voorspeller zijn voor het effect van een training. Bij het onderzoek naar meerwaarde van trainingen blijkt het ook nog van belang hoe deze geëvalueerd worden. In overeenstemming met de bevindingen van Salas en Cannon-Bowers (2001) benoemen Aguinis en Kraiger (2009) het model van Kirkpatrick als het meest toegepaste instrumentarium om trainingen te evalueren. Zij merken wel op, dat er tot nu toe weinig empirisch onderzoek heeft plaatsgevonden naar nieuwe evaluatiemethoden of evaluatieconcepten. Bovendien lijkt het in de praktijk lastig om gecontroleerd en empirisch onderzoek te verrichten. Uit onderzoek van Wang en Wilcox (2006) blijkt bijvoorbeeld dat vaak een wetenschappelijk acceptabel onderzoeksdesign ontbreekt. Voor het uitvoeren van een effectevaluatie wordt in de regel een experimenteel onderzoeksdesign als ideaal gezien (Baarda, \& de Goede, 2001; Mathieu et al., 1993; Wang \& Wilcox, 2006), waarin in ieder geval een experimentele onderzoeksgroep wordt vergeleken met een controlegroep waarin geen interventie plaatsvindt. Echter, in de praktijk ontbreekt het bij veldonderzoek vaak aan een controlegroep, duidelijke en meetbare onderzoeksvariabelen en een goede documentatie van het gehele proces (Haccoun \& Saks, 1998). Om toch tot een betrouwbare effectmeting te kunnen komen, maakt een aantal onderzoeken gebruik van de 'Internal Referencing Strategy' (waaronder Aguinis \& Brandstetter, 2007) 
om de problematiek rondom het ontbreken van een controlegroep te voorkomen (Garson, 2008; Haccoun \& Hamtiaux, 1994). Daarin worden niet-relevante aspecten meegenomen in het onderzoek, waarbij de aanname is, dat deze na de interventie niet veranderen, omdat er geen relatie is met de beoogde doelstelling. Anderen richten zich veel meer op het ervaren nut bij de deelnemers na een training en het daadwerkelijke effect in de praktijk, waarbij onderzoek gedaan aan de hand van zelfreflectie de objectiviteit van het onderzoek kan aantasten (Campbell \& Lee, 1988).

Aguinis en Kraiger (2009) sluiten hun review naar de meerwaarde van trainingen af met de conclusie, dat toekomstig onderzoek zich meer zou moeten richten op een meer integrale aanpak van de diverse niveaus van effecten (persoon, groep, organisatie en maatschappij). Ook is het van belang om rekening te houden met het moment waarop metingen worden verricht. Het effect van een training kan op termijn namelijk tot nieuwe vraagstukken in organisaties leiden, waardoor ook de oorspronkelijke vraagstelling van het onderzoek verandert. Daarnaast zou er een duidelijke relatie moeten worden gelegd tussen trainingsinhoud/design en de praktijksituatie. Over de invloed van individuele en situationele moderatoren (bevorderende en belemmerende factoren) is in dat verband nog weinig bekend. Volgens hen zal een training de beste resultaten behalen, wanneer deze is gerelateerd aan human resources management in de organisatie zelf en wanneer de principes van empirisch onderzoek worden opgevolgd een aanbeveling die in de praktijk vaak een grote investering (in tijd en middelen) betekent en derhalve niet snel wordt opgevolgd (Spitzer, 2005). Ook wat het rendement betreft in directe relatie tot de 'return of investment' blijven de auteurs sceptisch. Wel kan inzicht worden verkregen in het proces van een interventie en het effect daarvan worden verhoogd.

\section{Conclusie}

Samenvattend kan uit de aangetroffen resultaten van onderzoek naar de effectiviteit van trainingen van de afgelopen twee decennia (Aguinis \& Kraiger, 2009; Salas \& Cannon-Bowers, 2001) worden geconcludeerd, dat de aandacht naar gedegen onderzoek met betrekking tot de effectiviteit van trainingen en gedragsinterventies bij organisaties en onderzoekers is toegenomen. Verder zijn de modellen, toepassingsgebieden, training designs e.d., qua aantal en complexiteit sterk gegroeid. Toekomstig onderzoek naar het effect van trainingsinterventies zou zich dan ook veel meer op de volgende verbeterpunten moeten richten:

1. Het onderzoek moet integraal van aard zijn en niet slechts zijn gebaseerd op een enkel theoretisch concept, waarbij een keuze kan worden gemaakt voor een aanpak die het beste aansluit bij de behoefte van de deelnemers.

2. Naast de uitgangspositie ('hoe is het nu?') moet er ook aandacht geschonken worden aan transfer in de toekomst ('hoe / wat ga ik in de toekomst anders doen?').

3. Er moet rekening gehouden worden met situationele aspecten en dan vooral de barrières die nieuw gedrag in de weg kunnen staan.

4. Men werkt met duidelijke doestellingen, individuele verwachting ('self-efficacy') en legt een relatie tussen trainingssituatie en praktijk ('outcome-expectancy').

5. De aanpak is flexibel in leerinterval en meetmomenten.

6. Er wordt rekening gehouden met de omstandigheden waarbinnen een training wordt gegeven.

7. De omgeving wordt bij de training betrokken.

8. De interventies zijn 'evidence based'.

9. Er wordt met een duidelijke evaluatiemethode gewerkt.

10. De aanpak is procesmatig en bevordert dat de participanten leren van hun fouten. 


\subsection{Mogelijke perspectieven}

Uit de vorige paragraaf is duidelijk geworden, dat het aantal en de complexiteit van de onderzoeken naar de effectiviteit en het rendement van gedragsinterventies sterk is toegenomen. Een probleem dat zich bij het vergelijken van de diverse onderzoeken voordoet, is dat deze, naast verschillende benaderingen van het meten van effecten, ook verschillende modellen gebruiken en daardoor moeilijk met elkaar te vergelijken zijn. Zij verschillen in aanpak, meetmethode, design, theoretische concepten en zijn vaak onvoldoende gedocumenteerd (Aguinis \& Kraiger, 2001). Ook is duidelijk geworden, dat de diverse onderzoeken vaak deelaspecten van een training onderzoeken of dat er een specifieke leeropvatting aan ten grondslag ligt. Bovendien blijft het moeilijk gefundeerde uitspraken te kunnen doen over het rendement (return of investment') omdat een direct verband tussen kosten en opbrengsten volgens Russ-Eft \& Preskill (2005) te vergelijken is met de speurtocht naar de heilige graal. Door de theoretische en praktische ontwikkelingen op dit gebied is wel meer inzicht verkregen in het proces van een gekozen interventie (Alvarez, Salas \& Garofano, 2004). Een toekomstige aanpak zou zich, naast het meetbaar maken van de effecten van een interventie, dus ook moeten richten op het inzichtelijk maken van het doorlopen proces.

Om een antwoord te kunnen geven op de doelstelling van dit proefschrift is een methode gezocht die aansluit bij de 10 aanbevelingen die uit de reviews van Salas en Cannon-Bower (2001) en Aguinis en Kraiger (2009) naar voren zijn gekomen. Daarbij zou het wenselijk zijn, dat de diverse theoretische opvattingen over gedragsverandering naast elkaar kunnen bestaan en men zich specifiek richt op de probleemstelling en de evaluatie van een gedragsinterventie. Immers, een gemeenschappelijk kenmerk van de diverse theoretische denkkaders is, dat zij de nadruk leggen op de activiteiten die moeten plaatsvinden om gedragsverandering te realiseren. Bij een dergelijke methode zou de nadruk vooral moeten komen te liggen op het meetbaar maken van het effect van gedragsinterventies en van de beïnvloeding van gedrag en niet zozeer op welke interventiemethode is toegepast.

Conform deze aanbevelingen is in dit onderzoek gekozen voor een methode waarin rekening wordt gehouden met het inzichtelijk maken van het proces van gedragsveranderingen en het effect daarvan. De gekozen trainingsmethode, de aard van het gedrag of het gekozen trainingsdesign is dan minder van belang. Het gaat immers om het behalen van de beoogde resultaten. Een theoretisch kader dat goed aansluit bij deze doelstelling en een verklaring geeft voor specifiek gedrag is de 'Reasoned Action Approach' (Fishbein \& Ajzen, 2010) gebaseerd op de 'Theory of Planned Behavior' (TPB, Ajzen, $1985,1987,1991)$ en vormen de principes van het 'Reasoned Action Model', de basis van deze aanpak (zie figuur 2.9). De kern is dat men zich specifiek richt op de definitie van gewenst gedrag en van welke (persoonlijke) barrières daaraan ten grondslag liggen. Het maakt een soort foto van de actuele uitgangssituatie. Daarnaast biedt het een 'universeel' concept en methodologisch raamwerk om de effectiviteit van een interventie te bepalen zonder een uitspraak te doen over trainingsdesign, theoretische achtergrond of gehanteerd trainingsmodel (Fishbein \& Ajzen, 2010; p.359). Wat telt is de uitkomst van het waarneembare gedrag.

Het voordeel daarvan is dat, naast het effect van een training, ook onderzocht wordt welke voorwaarden aanwezig moeten zijn om verwachtingen in concreet gedrag om te zetten. Door de 'Reasoned Action Approach' systematisch als meetconcept bij gedrags- 
interventies en trainingen te gebruiken, zijn onderzoeken naar het effect van interventies beter met elkaar te vergelijken. Het vormt een soort 'thermometer' voor de effectmeting bij gedragsinterventies en sluit aan bij de aanbevelingen van Salas en Cannon-Bower (2001) en Aguinis en Kraiger (2009) uit de vorige paragraaf. Door deze aanpak toe te passen op de ontwikkeling van een gedragstraining of interventie wordt de uitkomst (beoogd gedrag) geconcretiseerd, worden barrières in kaart gebracht en kan er een indicatie van worden gegeven welke aspecten meer nadruk moeten krijgen tijdens een training of interventie.

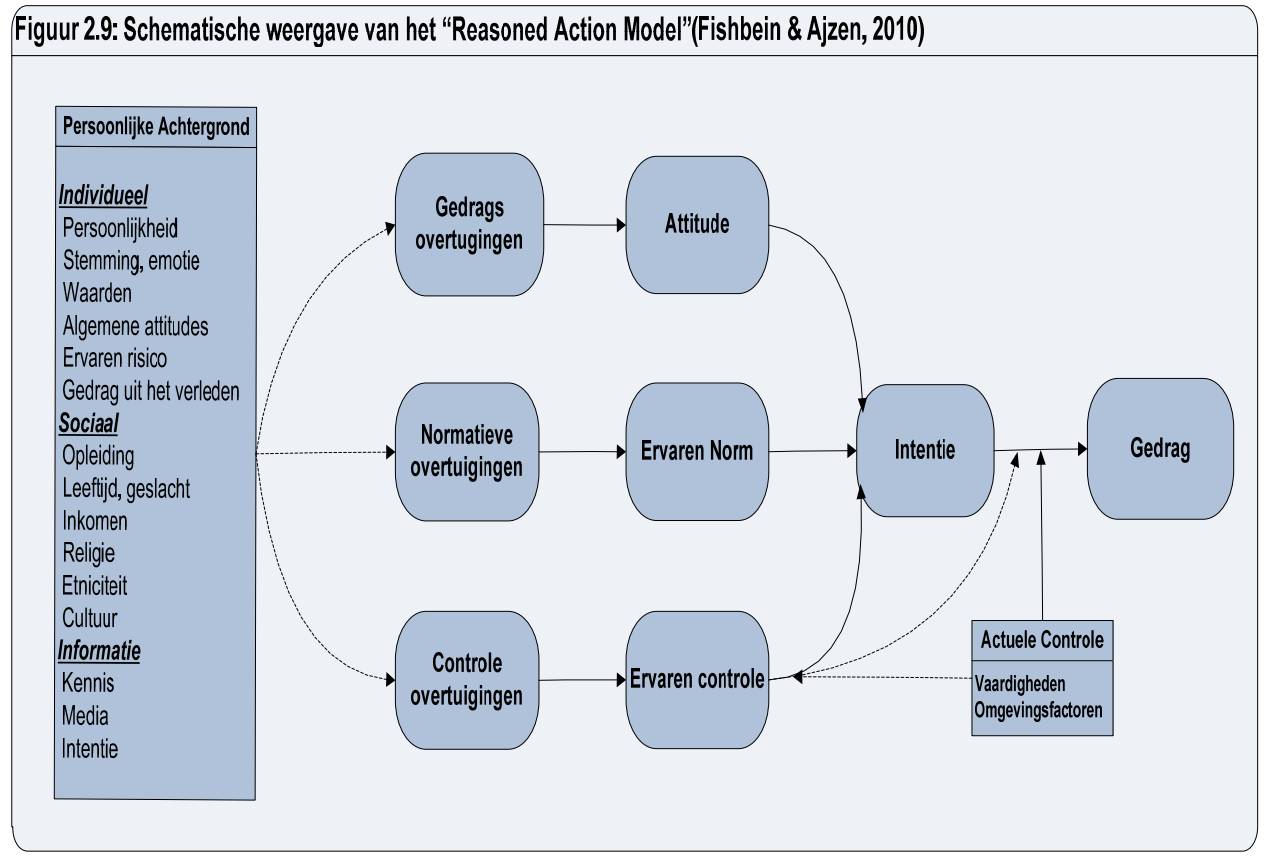

\subsection{Het 'Reasoned Action Model'}

Binnen het concept van de 'Reasoned Action Approach' (Fishbein \& Ajzen,2010) vormt het 'Reasoned Action Model' een centrale rol. Uitgangspunt bij dat model is, dat gedragsvoornemens ('intentie') goede voorspellers zijn voor het uiteindelijke gedrag in de praktijk (Fishbein \& Ajzen, 1975; Ajzen \& Fishbein, 1980). De basis voor gedrag is voor een deel afhankelijk van de persoonlijke achtergrond van een individu. Individuele kenmerken zoals persoonlijkheid, waarden en eerdere ervaringen spelen daarbij een rol. Ook sociaal-demografische kenmerken, waaronder leeftijd, geslacht, opleiding en cultuur, hebben invloed op iemands gedrag, evenals de informatie waarover een persoon beschikt. De fundamentele veronderstelling van dit model is, dat naarmate het gedragsvoornemen sterker is, de kans dat een persoon ook daadwerkelijk in actie komt groter wordt (Schifter \& Ajzen, 1985; Ajzen \& Madden, 1986). De mate van het gedragsvoornemen is daarbij afhankelijk van drie onderling samenhangende variabelen: 'attitude', 'ervaren norm' en 'ervaren controle'. 


\subsubsection{Attitude}

In het model van Fishbein en Ajzen wordt 'attitude' opgevat als een positief of negatief oordeel ten opzichte van bepaald gedrag. Deze omvat de persoonlijke voor- en nadelen van het uiteindelijke gedrag en het daaraan gekoppelde urgentiebesef. Het betreft dus de inschatting van de consequenties van het zelf vertonen van toekomstig gedrag. Deze inschatting is wederom afhankelijk van de positieve of negatieve verwachting die een persoon heeft ten opzichte van bepaald gedrag, de zogenaamde 'gedragsovertuiging', en verwijst naar de kosten/bateninschatting van bepaald gedrag ('outcome expectations') en de waarschijnlijkheid dat deze zich zullen voordoen ('beliefs'). De auteurs volgen hiermee een lange traditie van onderzoek naar attitudes ten opzichte van specifiek gedrag. Het betreft niet het gedrag zelf, maar een basisovertuiging ten opzichte van dat specifieke gedrag. Dit hoeft niet bewust te gebeuren en de meeste onderzoeken gaan er dan ook van uit dat het een leerproces betreft, waarin personen eerdere ervaringen meenemen in hun evaluatie. Een ander aspect is, dat het een verzameling is van verschillende evaluaties over één bepaald onderwerp en het daarmee een optelsom is van een aantal overtuigingen. Uit onderzoek blijkt dat personen ernaar streven om consistent te zijn in hun attitude en in het uiteindelijk gedrag en dat deze elkaar beïnvloeden. Fishbein en Ajzen benadrukken dat attitudes iets anders zijn dan waarden of overtuigingen. Waarden zijn algemener van aard dan attitudes, terwijl overtuigingen juist specifieker zijn. Waarden beschrijven meer een wenselijke toestand waarin een persoon wil verkeren en zijn niet gericht op een specifiek object of gedrag. Overtuigingen zijn in dat verband meer specifiek en vaak ook cognitiever. Ook zijn zij specifiek gericht op één bepaald object, in tegenstelling tot attitudes die veel globaler van aard zijn. Attitudes kunnen dus worden gezien als de optelsom van overtuigingen en hun beoordeling ten opzichte van specifiek gedrag of zaak. In het model zijn het onder andere de waarden die invloed hebben op de overtuigingen van een persoon, die wederom de 'attitude' vormen.

\subsubsection{Ervaren norm}

Een ander element is het begrip "ervaren norm', dat verwijst naar de verwachtingen vanuit de sociale omgeving die een persoon ervaart ten opzichte van bepaald gedrag. Deze norm wordt gevormd uit de ervaren overtuigingen van personen of groepen in de directe omgeving en heeft volgens Fishbein en Ajzen een sterke invloed op iemands intenties en acties. Het is de sociale druk die een omgeving op een persoon uitoefent in de vorm van verwachtingen van belangrijke personen of groepen in de directe omgeving. Daarbij is de aanname, dat een persoon het eigen gedrag laat afhangen van de verwachtingen die uit de eigen omgeving worden gecreëerd en de daaraan verbonden sancties of negatieve gevolgen voor de persoon zelf. Het is niet alleen van belang welke normatieve verwachtingen een persoon van anderen over diens eigen gedrag heeft ('normatieve overtuigingen'), maar ook de mate waarin men zich er zelf iets van aantrekt. Anderzijds verwijst het begrip ook naar het voordeel dat een persoon vanuit de eigen sociale omgeving zou kunnen verwachten. Het betreft de sociale of emotionele steun, maar er kan ook sprake zijn van voorbeeldgedrag. De auteurs maken daarbij een onderscheid in 'injunctieve' en 'descriptieve' normen. Injunctieve normen beschrijven wat personen over het algemeen denken dat ze moeten doen ('Je moet op tijd op het werk verschijnen.') en descriptieve normen laten zien, wat mensen denken dat anderen doen ('Het overgrote gedeelte van mijn collega's verschijnt op tijd.'). Beiden hebben invloed op het gedrag van een persoon, ten positieve of ten negatieve. Injunctieve normen zijn in dat verband veel meer gericht op een bepaalde actie. Descriptieve normen daarentegen zijn veel meer gerelateerd aan een bepaalde groep. 


\subsubsection{Ervaren controle}

Naast 'attitude' en de "ervaren norm" heeft ook de verwachting ("ervaren controle") van een persoon dat hij of zij bepaald gedrag in de praktijk kan vertonen, invloed op de 'intentie' en daarmee op het uiteindelijk gewenste gedrag. Het weerspiegelt het vertrouwen dat iemand heeft in de eigen vaardigheden en de barrières die deze persoon in een specifieke situatie verwacht. Deze worden gevormd uit persoonlijke en omgevingsfactoren die ondersteunend zijn aan het beoogde gedrag ('self-efficacy').

Tevens geeft Ajzen (1991) aan, dat 'ervaren controle' direct invloed kan hebben op het gedrag, los van de gedragsvoornemens. Bovendien kunnen een gebrek aan vaardigheden of de aanwezigheid van belemmerende omgevingsfactoren ('Actuele Controle') personen ervan weerhouden om bepaald gedrag te vertonen. Fishbein en Ajzen (2010) gaan in hun model ervan uit, dat de 'ervaren controle' ook een direct modererend effect heeft op het uiteindelijke gedrag van personen. Als men ervan overtuigd is geen controle op een bepaald resultaat of gedrag uit te kunnen oefenen, zal dat een negatieve invloed hebben op het gewenste resultaat, ongeacht mogelijke positieve attitudes of een hoge sociale druk. Het betreft daarbij interne en externe factoren die bepaald gedrag bevorderen of juist in de weg staan.

\subsubsection{Intenties}

Het mechanisme dat aan het model van Fishbein en Ajzen ten grondslag ligt, is een beredenerende benadering van de mens en diens (deels bewuste en deel onbewuste) keuze voor bepaald gedrag. Zij beschouwen gedragsvoornemens ('intenties') als een subjectieve opvatting om bepaald gedrag te vertonen. De veronderstelling is dat mensen een bewuste inschatting maken van hun kansen op gewenste resultaten van bepaald gedrag. Uiteindelijk kiest men voor gedrag dat in de beleving van een persoon zelf de grootste kans op een positieve uitkomst biedt. Zo beredeneerd, is gedrag de som van de keuzes uit verschillende gedragsmogelijkheden en het geloof in de meest positieve uitkomst en de overtuiging dat men het ook daadwerkelijk zelf kan realiseren. Het zegt dus niets over een objectief of rationeel gezien beste oplossing, omdat personen in het algemeen heel irrationele redenen kunnen hebben voor hun gedrag. Wel zijn de gedragsvoornemens ('intenties') daarin de beste voorspellers voor het al dan niet optreden van later gedrag. In diverse onderzoeken is voldoende bewijs geleverd, dat 'intenties' een directe correlatie hebben met het uiteindelijke gedrag. In de praktijk zijn deze voornemens ook gemakkelijk te meten, omdat zij tweedimensionaal zijn: iemand is voornemens bepaald gedrag te vertonen of niet. Met dit model kan dus niet alleen worden gemeten wat het succes van een gedragstraining is, maar kan ook worden bepaald wat de kans is op gedragsverandering en welke factoren een rendement bevorderen of belemmeren. Van cruciaal belang zijn bij de beschrijving van het gewenste gedrag: de 'actie' zelf, het 'doel', de 'context' en de 'tijd' (Fishbein \& Ajzen 2010, p.29 ff). De veronderstelling is, dat naarmate een gedragsbeschrijving duidelijker gekoppeld is aan deze vier condities, ook de voorspellende waarde van een gedragsvoornemen toeneemt. Deze vormen in de ogen van de auteurs de specificiteit van het te onderzoeken gedrag. De basis voor het 'Reasoned Action Model' vormt dus een beredeneerde keuze voor gedrag. Het doet geen uitspraak over automatismen, gewoonten, cultuur of impulsen, en is een bewuste (of deels onbewuste) afweging die een persoon maakt. Een voorwaarde voor gedragsverandering is, dat gedrag expliciet en daarmee bewust wordt gemaakt om het ook daadwerkelijk te kunnen veranderen (Eshetu, G.; 2013). 
Fishbein en Ajzen (2010) zijn ervan overtuigd, dat het 'Reasoned Action Model', samen met de daaruit ontwikkelde 'Reasoned Action Approach' ertoe kan bijdragen effectieve gedragsinterventies door te voeren en te meten. Ook maakt het een vergelijking mogelijk tussen personen die bepaald gedrag wel vertonen en personen die dat niet doen, en het helpt trainingen effectiever in te richten. Over de aard van de interventie wordt in het model geen uitspraak gedaan.

In de praktijk blijkt het model zeer bruikbaar te zijn voor de verklaring van gedrag (onder andere Ajzen, 1991; Armitage \& Conner, 2001; Fishbein et al., 2003). Fishbein et al. (2003) vinden onder andere aanwijzingen dat de drie variabelen ('attitude', 'ervaren controle' en 'ervaren norm') een groot deel van de variatie in gedragsvoornemens verklaren. Een goede voorspellende waarde voor gedragsvoornemen vinden Kaiser en Gutscher (2003) in hun onderzoek naar milieubewust gedrag; de drie variabelen verklaarden samen maar liefst $81 \%$ van de variatie in het voornemen om milieubewust te handelen. Vooral in de gezondheidsvoorlichting en beïnvloeding wordt het 'Reasoned Action Model' veelvuldig gebruikt om gezondheidgerelateerd gedrag te veranderen. Te denken valt aan bijvoorbeeld campagnes met betrekking tot het stoppen met roken, veilig vrijen of gezond eten. In alle gevallen gaat het om specifiek gedrag en om het voornemen is om brede bevolkingsgroepen tot ander (gezonder) gedrag te bewegen. Maar ook in andere gevallen, waaronder het verhogen van de verkeersveiligheid (XTNT, 2013), het terugdringen van huiselijk geweld (Sulak, Saxon \& Fearon, 2014), het beïnvloeden van irrigatiemethodes onder Australische boeren (Jorgensen \& Martin, 2014) of het gebruik van digitaal lesmateriaal door leraren (Kreijns et al., 2013), groeit de belangstelling om gedrag op een effectieve manier te kunnen beïnvloeden en wordt onder het begrip 'liberaal paternalisme' of 'nudge theory' aangeduid. Daarbij wordt aangenomen dat positieve beloning en indirecte sturing de motivatie en het gedrag van personen of groepen effectiever beïnvloedt dan directie instructie of dwang. Onderzoek van Ajzen, Brown en Carvajal (2004) laat zien dat 'gedragsintenties' een goede voorspeller zijn voor daadwerkelijk gedrag, mits de variabelen van het model in een realistische context worden geplaatst. Voor gedragstrainingen in het bedrijfsleven kan men aannemen, dat het 'Reasoned Action Model' verklaart waarom beoogde resultaten niet of moeilijk worden behaald. Ook biedt de mate van 'gedragsintentie', het voornemen om bepaald ander gedrag te willen vertonen, een goede voorspelling van het uiteindelijke resultaat in de praktijk, zonder dat er ingewikkelde evaluatiemethoden ontwikkeld hoeven te worden. Neem bijvoorbeeld een training functioneringsgesprekken. Het voeren van een functioneringsgesprek bestaat uit diverse deelgedragingen die allemaal zouden moeten worden gemeten. Met het begrip 'intentie' volstaat het om te vragen of een persoon met zijn/haar medewerkers de komende $\mathrm{X}$ maanden daadwerkelijk een functioneringsgesprek zou voeren. Voor gedragstraining is hiermee de mogelijkheid geboden om het effect op het beoogde gedrag door middel van de waargenomen 'gedragsintentie' te bepalen, zonder dat (soms complex en uit meerdere deelgedragingen bestaand) specifiek gedrag daadwerkelijk in te praktijk gemeten hoeft te worden.

Abraham, Sheeran en Johnston (1988) benadrukken in dit verband, dat de voorspelling voor het gewenste gedrag beter wordt naarmate de omschrijving van het gedrag beter overeenkomt met de omschrijving van de gedragsvariabelen. Ajzen (1991) ziet een grondige inventarisatie van de gevolgen die iemand in belangrijke mate verbonden ziet aan een bepaald gedrag, als voorwaarde voor goed onderzoek. Reeds eerder is vermeld dat de voorspellende waarde van de 'gedragsintentie' toeneemt naarmate het gewens- 
te gedrag specifieker omschreven is in termen van het doel van het gedrag, de situatie of context waarin het gedrag plaatsvindt, het tijdstip waarop het gedrag zou moeten plaatsvinden en de plaats waar het gedrag zou moeten plaatsvinden. Het 'Reasoned Action Model' is door focus op waarneembaar en ingekaderd gedrag uitstekend te operationaliseren. In talrijke onderzoeken en ook door Fishbein en Ajzen worden concrete voorbeelden gegeven van geschikte meetinstrumenten. Daarin wordt naast het beoogde gedrag vooraf onderzocht wat de kans is dat bepaald gedrag wordt vertoond en welke bevorderende of belemmerende factoren (barrières) een rol spelen. Mc Eachan et al. (2011) concluderen in hun meta-analyse van onderzoeken naar gezondheidbevorderend gedrag dat naast de goede voorspellende waarde van het model ook andere factoren zoals duur van de follow-up, zelfrapportage of leeftijd mede van invloed zijn op het daadwerkelijke resultaat.

Conform de uitkomsten uit de reviews van Salas en Cannon-Bowers (2001) en Aguinis en Kraiger (2009) en de daarin gevonden aanbevelingen voor verder onderzoek naar het rendement van trainingen biedt het 'Reasoned Action Model' een oplossing voor zes van de tien eerder geformuleerde aanbevelingen (pagina 33):

- Het is integraal van aard en niet slechts gebaseerd op een enkel theoretisch concept waarbij een keuze kan worden gemaakt voor een aanpak die het meeste invloed uitoefent op de deelnemers.

- Naast de uitgangspositie ('hoe is het nu?') wordt er ook aandacht geschonken worden aan transfer in te toekomst ('hoe/wat ga ik in de toekomst anders doen?').

- Er wordt rekening gehouden worden met situationele aspecten en dan vooral de barrières die nieuw gedrag in de weg kunnen staan.

- Het betreft duidelijke doestellingen, individuele verwachting ('self-efficacy') en legt een relatie tussen trainingssituatie en praktijk ('outcome-expectancy').

- Er wordt rekening gehouden met de omstandigheden waarbinnen een training wordt gegeven.

- Er wordt met een duidelijke evaluatiemethode gewerkt.

Voor de resterende vier aanbevelingen betreffende een flexibele aanpak, het betrekken van de omgeving bij de interventie, een 'evidence based' methode en een procesmatige aanpak worden in het model van Fishbein en Ajzen (2010) onvoldoende aanknopingspunten gegeven of worden zelfs geen uitspraken gedaan. Voor een geïntegreerde methode zoals Salas en Cannon-Bowers (2001) en Aguinis en Kraiger (2009) die aanbevelen, zal dus naar een aanvullend concept of aanvullende aanpak moeten worden gezocht. Het in veel onderzoeken terugkerend concept van "Intervention Mapping", dat succesvol bij gezondheidsbevorderende campagnes wordt toegepast, kan hiervoor uitkomst bieden.

\section{5 'Intervention Mapping'}

Voor de praktische toepassing en de transfer van voorbeeldgedrag in de praktijk (bijvoorbeeld bij gezondheidsvoorlichting en in de gezondheidspsychologie) wordt veelvuldig gebruik gemaakt van "Intervention Mapping" (IM, Bartholomew et al., 2001; 2006; Schaalma et al., 2001) als methode om gewenst gedrag op een systematische manier te verankeren. De 'Intervention Mapping'-methode' kent zijn oorsprong in de toepassing van een protocollaire aanpak bij gezondheidsbevorderende campagnes. Vooral vanaf de jaren ' 90 is hieraan systematisch gewerkt en zijn er talrijke gegevens en inzichten ontwikkeld over interventies die gericht zijn om gezond gedrag te bevorderen. 
Het is een beschrijving c.q. handleiding hoe dergelijke programma's ontworpen en geevalueerd kunnen worden.

De kracht ervan is, dat interventies op een systematische manier ontwikkeld, uitgevoerd en geëvalueerd worden. Met behulp van een gestructureerde en planmatige aanpak wordt een maatwerkprogramma ontwikkeld, waarbij een duidelijke definitie en afbakening van het beoogde gedrag voorop staat. Eén randvoorwaarde is dat het beoogde gedrag, de doelgroep en de daaraan verbonden belemmerende en bevorderende factoren voldoende duidelijk moeten zijn. Daarmee heeft de IM-methode een duidelijke relatie met de 'Reasoned Action Approach'. Na een vooronderzoek behelst IM vijf opeenvolgende stappen die aan de daadwerkelijke interventie voorafgaan (zie figuur 2.10).

Figuur 2.10: Schematische weergave IM (overgenomen uit Bartholomew et al., 2001)

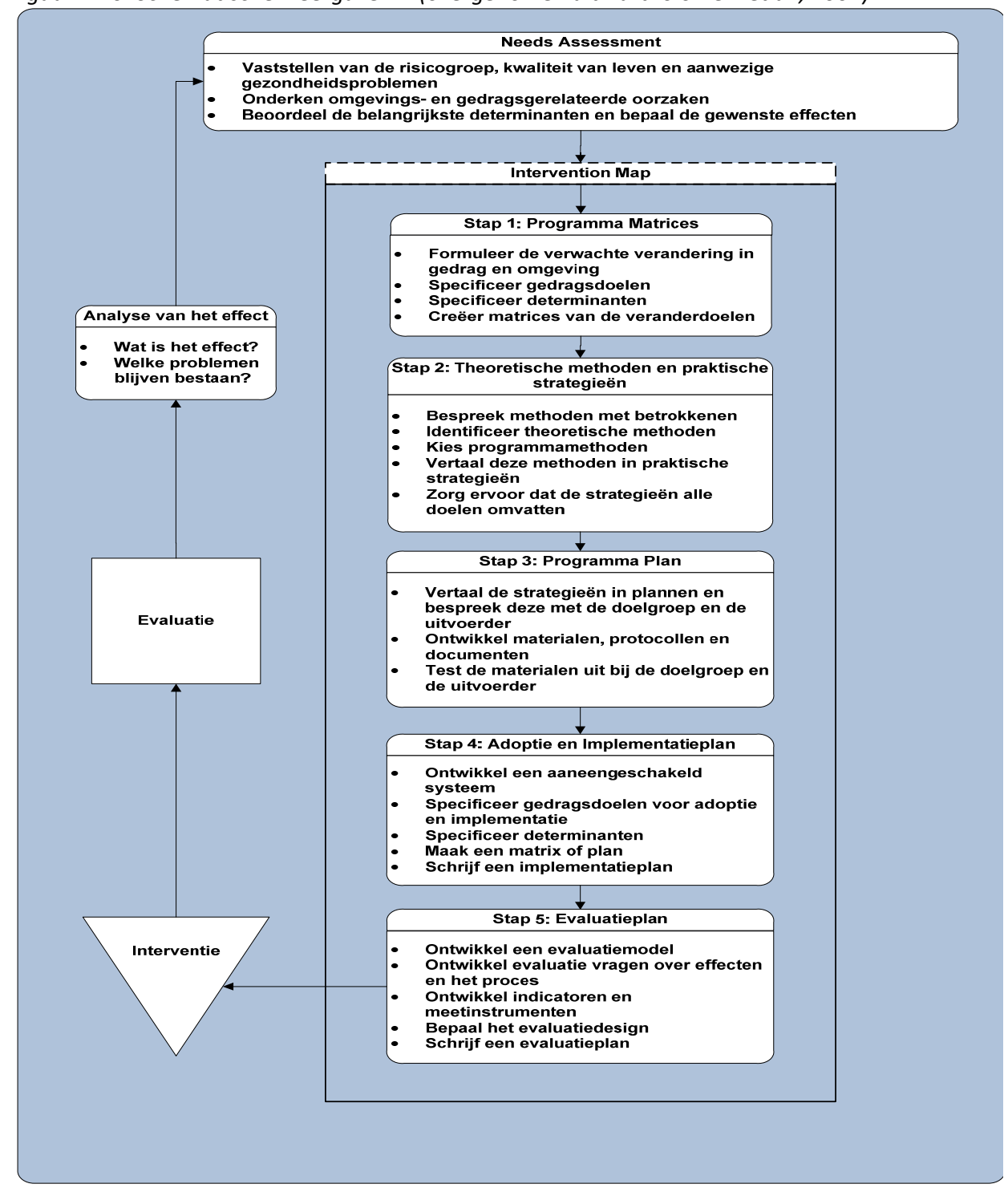


In tegenstelling tot de wereld van trainingen wordt in de gezondheidszorg en in de gezondheidsvoorlichting veelvuldig van deze aanpak gebruik gemaakt. Interventies laten zich gemakkelijker vergelijken, zijn beter gedocumenteerd en er kan door de systematische aanpak van fouten worden geleerd. De basis van de methode vormt een 'evidence based' aanpak, waarin een aantal concrete doelstellingen en producten worden gerealiseerd.

Het gehele proces start met een probleemanalyse ('Needs Assessment') en behelst het concretiseren van het probleem. Voordat aan een interventie wordt begonnen, moet eerst het probleem gedefinieerd zijn, het daarbij behorende gedrag duidelijk omschreven zijn, de doelgroep duidelijk gedefinieerd zijn en dienen omgevingsfactoren in kaart te zijn gebracht. De uitkomst is een beschrijving van het probleem en de impact op het gedrag in relatie tot de omgeving. Daarbij worden naast inhoudsdeskundigen ook personen uit de doelgroep betrokken.

In stap 1 worden het gewenste gedrag en de condities waaronder dit plaatsvindt, zo duidelijk mogelijk omschreven en worden belemmerende en bevorderende factoren zo grondig mogelijk in kaart gebracht. Daarbij wordt aangegeven wat een persoon moet doen om van gedrag te veranderen en wat er in de omgeving ook daadwerkelijk zal veranderen (zichtbaar is). Hoe beter en meer afgebakend het betreffende gedrag kan worden benoemd, des te gemakkelijker kunnen interventies worden ontwikkeld en kan het effect gemeten worden. Verder is het in deze fase van belang om aan de hand van eerdere onderzoeken, literatuur en theorieën er een inschatting van te kunnen maken welke interventie - gegeven de omstandigheden - het meeste effect op het gewenste gedrag zal hebben.

In stap 2 worden aan de hand van theoretische modellen en voorbeelden uit de praktijk de interventiestrategie(en) verder uitgewerkt. Daarbij wordt zoveel mogelijk gebruik gemaakt van de interventiegroep zelf. In deze fase worden de eerste ideeën omgezet in oplossingsrichtingen die nauw aansluiten bij de beoogde veranderdoelstelling. Interviews en het inrichten van referentiegroepen zijn een geëigend middel om de doelgroep bij de interventie te betrekken.

In stap 3 worden deze strategieën omgezet in een interventieprogramma, dat vervolgens (zo mogelijk) in een pilot op toepassing en bruikbaarheid wordt getoetst. Het is van belang de beoogde programmaonderdelen en het materiaal te toetsen.

Vervolgens wordt in stap 4 nader onderzocht wie het programma uit moet voeren en welke randvoorwaarden noodzakelijk zijn voor succes. Verantwoordelijkheden en bevoegdheden worden daarbij duidelijk in een implementatieplan vastgelegd. Ook worden de afzonderlijke interventies tot één geheel samengevoegd.

Uiteindelijk worden in stap 5 een evaluatieplan en evaluatiemethode ontwikkeld waarin het effect en de aanpak centraal staan.

Het resultaat van deze stappen is een strategie om interventies te ontwerpen en het effect daarvan te meten. Tevens wordt optimaal gebruik gemaakt van bestaande expertise en kennis uit het verleden en van de betreffende doelgroep zelf. 
Het ligt dus voor de hand om deze gestructureerde methode ook op gedragstrainingen toe te passen, omdat deze zich niet zozeer richten op het verwerven van kennis, maar met name zich richten op het aanleren van gewenst of gewijzigd gedrag. Bovendien biedt de IM-methode het voordeel, dat aan de aanbevelingen van Aguinis en Kraiger (2009) voor toekomstig onderzoek op de volgende punten navolging wordt gegeven:

- Het is integraal van aard en niet slechts gebaseerd op een enkel theoretisch concept, waarbij een keuze kan worden gemaakt uit een aanpak die het meest invloed uitoefent op de deelnemers.

- Er wordt rekening gehouden met situationele aspecten en dan vooral de barrières die nieuw gedrag in de weg kunnen staan.

- Het betreft duidelijke doestellingen, individuele verwachting ('self-efficacy') en legt een relatie legt tussen trainingssituatie en praktijk ('outcome-expectancy').

- De aanpak is flexibel in leerinterval en meetmomenten.

- De omgeving wordt bij de training betrokken.

- De aanpak is procesmatig en bevordert het leren van fouten.

- De interventie is 'evidenced based'.

\subsection{Een geïntegreerde methode}

De beschrijving van de ontwikkelingen bij gedragstrainingen van de afgelopen twee decennia van Salas en Cannon-Bowers (2001) en Aguinis en Kraiger (2009) hebben duidelijk gemaakt, dat er behoefte is aan een meer systematische aanpak bij het onderzoek naar effectiviteit van (gedrags)trainingen. Met de uitgangspunten van de 'Reasoned Action Approach' van Fishbein en Ajzen (2010) in combinatie met de basisprincipes van 'Intervention Mapping' lijkt een raamwerk te worden gelegd, waarin deze aanbevelingen voor toekomstig onderzoek naar gedragstrainingen zijn verwerkt. Daarbij vormt het 'Reasoned Action Model' de basis voor het meetinstrument en geeft met de drie factoren 'attitude', 'ervaren norm' en 'ervaren controle' de mogelijkheid een interventie maximaal aan te laten sluiten bij de bevorderende en belemmerende factoren die van invloed zijn op gewenst gedrag. De basisprincipes van 'Intervention Mapping' zijn daarbij het gestandaardiseerde proces waarbinnen diverse interventies, trainingen en gedragsveranderingen kunnen plaatsvinden. Het voordeel van een dergelijke aanpak is, dat de meetmethode (het instrument) en het proces nagenoeg hetzelfde blijven, waardoor de diverse interventiemethoden onderling vergelijkbaar zijn en op hun meerwaarde kunnen worden beoordeeld. Bovendien vullen beide concepten elkaar ook goed aan en maakt een meetinstrument gebaseerd op de 'Reasoned Action Approach' het noodzakelijk om gewenst gedrag zo specifiek mogelijk te omschrijven in de termen van 'actie, het doel, de context en de tijd. Verder komt deze aanpak aan de doelstelling van dit proefschrift tegemoet om een zo gestandaardiseerd mogelijk meetinstrument en zo gestandaardiseerd mogelijke aanpak te ontwikkelen waarmee de effectiviteit van gedragstrainingen in verschillende omgevingen met elkaar kunnen worden vergeleken zonder dat daarbij voor een specifieke interventiemethode wordt gekozen. Ten slotte zou met een dergelijke methode meer (economisch) rendement behaald kunnen worden uit gedragsinterventies in organisaties. 
Een geïntegreerde onderzoeksmethode gebaseerd op eerder beschreven conclusies en aanbevelingen kan schematisch als volgt weergegeven worden (figuur 2.11):

1. Om te beginnen is het noodzakelijk het probleem te definiëren en duidelijke doelen vast te stellen. Hierdoor kunnen in een zo vroeg mogelijk stadium de belemmerende en bevorderende factoren in kaart worden gebracht. Dit komt overeen met 'Needs Assessment' uit 'Intervention Mapping' (figuur 2.10). Parallel daaraan wordt gewenst gedrag gedefinieerd en worden de eerste indicatoren uit het 'Reasoned Action Model' ingevuld.

2. Het resultaat is een eerste inschatting van de 'attitude', 'ervaren norm' en 'ervaren controle' ten opzichte van het gewenste gedrag. Door interviews en het betrekken van de doelgroep worden deze meer gespecificeerd en kunnen verbanden worden gelegd tussen beoogd resultaat en aanwezige barrières.

3. Samen met een referentiegroep en mogelijk andere experts wordt onderzoek gedaan naar eerdere onderzoeksresultaten, theorieën en strategieën betreffende deze problematiek om uiteindelijk een verandermethode te kunnen kiezen.

4. Bij deze stap kan de eerste meting met de vragenlijst gebaseerd op het 'Reasoned Action Model' worden doorgevoerd. De uitkomsten van deze eerste meting bieden het voordeel, dat inzicht kan worden gegeven in 'attitude', 'ervaren norm' en 'ervaren controle', waardoor ook de verandermethode mede kan worden bepaald. Bij een lage 'attitude' zal bijvoorbeeld eerder voor voorlichting en een inzichtgevende aanpak kunnen worden gekozen. Bij een lagere 'ervaren norm' kunnen interventies veel meer gericht zijn op overtuigingen en het beïnvloeden van de sociale omgeving. Een lage 'ervaren controle' duidt veel eerder op onvoldoende randvoorwaarden (middelen) en vaardigheden bij de deelnemers die moeten worden getraind.

5. Met de uitkomst van de eerste meting en literatuurstudie wordt een programmaplan opgesteld, dat moet uitmonden in een definitief interventieprogramma.

6. Voor een evaluatieplan wordt de tweede en mogelijk derde meting met het meetinstrument bepaald. Ook wordt gekeken hoe het programma wordt geëvalueerd.

7. Na de interventie wordt de tweede meting afgenomen en door middel van statistisch onderzoek het succes van de interventie bepaald.

8. Uiteindelijk wordt op basis van de aangetroffen uitkomsten een verbeterplan opgesteld en zo nodig opnieuw een interventie gepleegd, waarbij de doelgroep nauw wordt betrokken bij alle te volgen activiteiten.

De veronderstelling is, dat door de toepassing van een dergelijke aanpak inzicht wordt gegeven in het rendement van een interventie en belemmerende en bevorderende factoren specifiek in kaart zijn gebracht, waardoor uiteindelijk procesoptimalisatie van vervolgstappen gerealiseerd wordt. Er worden dus naast inzicht in het rendement/effect van een interventie ook verbetermogelijkheden voor de toekomst aangeboden.

In de volgende hoofdstukken zal eerst worden ingegaan op de ontwikkeling van het meetinstrument (hoofdstuk 3). Vervolgens zal aan de hand van 3 casestudies (hoofdstuk 4) het gebruik en de meerwaarde voor organisaties en onderzoekers worden getoetst. Uiteindelijk zal het onderzoeksdesign en specifiek het vraagstuk van het gebruik van een controlegroep (hoofdstuk 5) worden getoetst. In de conclusie en discussie (hoofdstuk 6) zal kritisch op de vraagstelling en de hypothese van dit proefschrift worden ingegaan.

Figuur 2.11: De ontwikkelde, geïntegreerde methode 


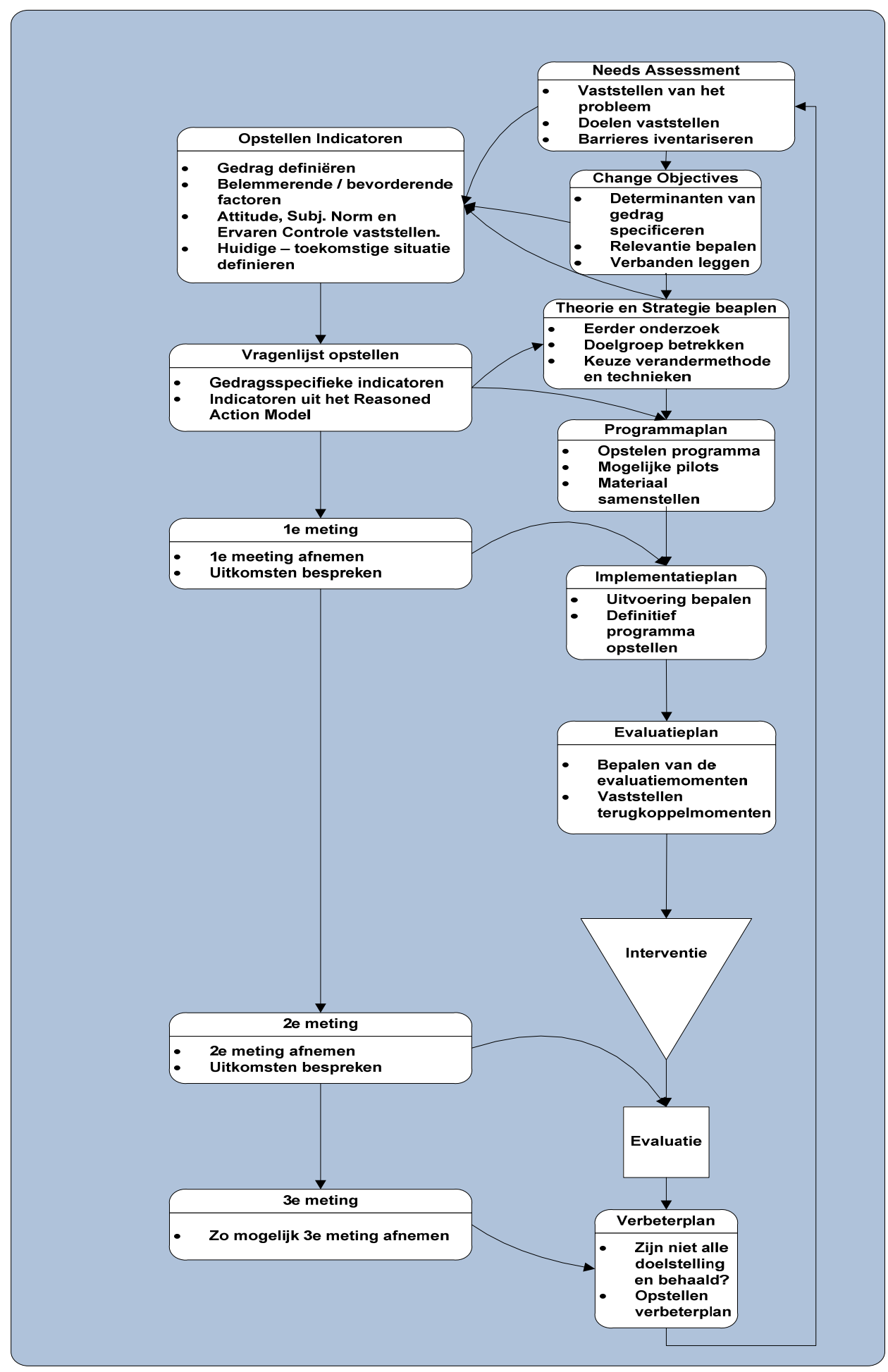

44 | Procesoptimalisatie van gedragsinterventies 


\section{Ontwikkeling van het meetinstrument ${ }^{1}$}

\subsection{Uitgangspunten en context}

De doelstelling van dit proefschrift is inzicht in de effectiviteit en het proces van (gedrags)interventies te realiseren. Een van de aannames is, dat gedragsinterventies die gebaseerd zijn op een aanpak waarin gebruik wordt gemaakt van de variabelen die van invloed zijn op het gewenste gedrag van de deelnemers, een versterkend effect hebben op het rendement en het uiteindelijke resultaat. Daarvoor is het noodzakelijk het effect van een interventie te kunnen meten en inzicht te verkrijgen in de belemmerende en bevorderende factoren van dat beoogde resultaat. Conceptueel wordt deze aanname versterkt door de conclusies die door Salas en Cannon-Bowers (2001) en Aguinis en Kraiger (2009) in hun beschrijving over de ontwikkelingen van onderzoek naar gedragstrainingen in de afgelopen 20 jaar. Op basis van hun aanbevelingen maakt dit onderzoek gebruik van bestaande modellen en concepten. Voor het meten van het effect van gedragsinterventies is gekozen voor de 'Reasoned Action Approach' van Fishbein en Ajzen (2010) en het daarin gehanteerde model, ten eerste, omdat op het gebied van het voorspellen en meten van gedrag dit een veelvuldig onderzocht en beproefd concept is en, ten tweede, omdat de probleemstelling van dit onderzoek zich expliciet richt op het meetbaar maken van gedragsverandering. De praktische doelstelling was dan ook om een redelijk eenvoudig, niet tijdrovend, gemakkelijk te verwerken en zoveel mogelijk gestandaardiseerd meetinstrument te ontwikkelen dat gedragsverandering meetbaar maakt. Omdat Aguinis en Kraiger (2009) ook pleiten voor meer gestructureerd en gedocumenteerd onderzoek is als onderzoek raamwerk gebruik gemaakt van de principes van 'Intervention Mapping' (Bartholomew et al., 2006).

Met de in 'Reasoned Action Approach' (Fishbein \& Ajzen, 2010) en 'Intervention Mapping' (Bartholomew et al., 2006) beschreven principes wordt in theoretische zin een positief concept weergegeven voor de beantwoording van de geformuleerde vraagstellingen. Een probleem van heel andere orde betreft de toepassing daarvan in de praktijk en het vinden van een geschikte (trainings)situatie. Gedurende een heel jaar is gezocht naar een organisatie waarin de kans op een relatief grote steekproefomvang geboden werd, de mogelijkheid aanwezig was voor zo gecontroleerd mogelijke omstandigheden in relatie tot de interventie, voldoende kennis uit het verleden beschikbaar was en van een controlegroep gebruik kon worden gemaakt. Een van de grootste problemen betrof de complexiteit van de boogde gedragsverandering en de daarmee samenhangende validiteit van het onderzoek. Samen met de opdrachtgever is veel zorg besteed aan het concretiseren en operationaliseren van gedragscriteria en het onderzoeken van bevorderende en belemmerende factoren bij de doelgroep. Ook het vertalen van eerder ontwikkelde meetinstrumentaria uit een gezondheidszorgcontext naar het bedrijfsleven (Empelen, Schaalma, Kok \& Jansen; 2001) hebben een lange periode in beslag genomen. Ook is met de opdrachtgever bediscussieerd hoe vaak een meting zou kunnen worden verricht (aantal meetmomenten) en heeft de opdrachtgever uit-

Dit hoofdstuk is voor een groot deel gebaseerd op het artikel Rauner, M., Kok, G., en Taris, T. (2005). De effectiviteit van een communicatietraining: Een vergelijking van de effectiviteit van een maatwerkprogramma en een standaardprogramma binnen een training effectieve communicatie. Gedrag \& Organisatie, 19, 3-21. 
eindelijk besloten dat het onderzoek binnen de bestaande opleiding en contactmomenten moest plaatsvinden. Voorwaarde was dat het onderzoek weinig impact op de training of het werk van de deelnemer mocht hebben. Derhalve zijn bij het onderzoeksdesign dan ook enkele concessies gedaan:

1. De validiteit heeft zich beperkt tot het bepalen van een 'expertvaliditeit'

2. Het onderzoek kon wat de trainers betrof niet dubbel blind worden uitgevoerd, omdat het aantal trainers voor de cursus beperkt was. De deelnemers waren niet op de hoogte in welke groep (experimenteel / controle) zij ingedeeld werden.

3. Er is geen zuivere experimentele controlegroep design uitgevoerd. Een controlegroep waarbij geen interventie werd gegeven, ontbrak.

4. De omvang van de onderzoeksgroep en de controlegroep bleef relatief beperkt.

5. Het ontwikkelde meetinstrument was tegelijkertijd ook een feedbackinstrument voor alle deelnemers, waardoor de uitkomstvariabele zou kunnen zijn beïnvloed.

Deze geschetste uitgangspunten zijn zeker niet optimaal en bij de ontwikkeling van het meetinstrument is daarmee wel zoveel mogelijk rekening gehouden. Waar mogelijk is naar oplossingen gezocht om verantwoord onderzoek uit te voeren. Zo is bij de ontwikkeling van het meetinstrument een ruim aantal oud-deelnemers geïnterviewd (51 personen) en is voor het bepalen van de expertvaliditeit gebruik gemaakt van 18 deskundigen uit het veld en de organisatie zelf. Door de ongunstige uitgangpositie voor dit onderzoek zijn wat betreft opzet en statistische verwerking enkele concessies gedaan, die later in de discussie nader zullen worden toegelicht. In het volgende hoofdstuk wordt de ontwikkeling van het meetinstrument, gebaseerd op de 'Reasoned Action Approach', en de ontwikkeling van een gestructureerde aanpak conform het IM-proces verder uitgewerkt. Met de twee gekozen raamwerken, de 'Reasoned Action Approach' en de principes van IM, wordt het effect van een interventie in kaart gebracht en het proces van de interventie geoptimaliseerd. Uitgangspunt vormt het betrekken van de voor het beoogde resultaat belemmerende en bevorderende factoren van de deelnemers bij de voor hun situatie meest geschikte oplossingsrichting(en). Om deze verwachting te kunnen toetsen, is een specifiek op deze doelstellingen gebaseerd meetinstrument ontwikkeld. Door uiteindelijk het meetinstrument en de gekozen methode te standaardiseren, wordt ook gewaarborgd, dat onderzoeken naar procesoptimalisatie bij gedragsinterventies in diverse settingen met elkaar kunnen worden vergeleken. Er wordt immers geen uitspraak gedaan over de te kiezen aanpak of interventie zelf. Wat telt is de gemeten verandering door de tijd heen. 


\subsection{Het meetinstrumentarium}

\subsubsection{Het ontwikkelproces}

De ontwikkeling van het meetinstrument heeft plaatsgevonden binnen een regulier opleidingsaanbod van een multinational met meer dan 6.000 medewerkers in Nederland. De organisatie is een productiebedrijf en bestaat uit meerdere zelfstandige businessunits. De afgelopen jaren was de organisatie met name gericht op het herstructureren van diverse bedrijfsonderdelen in zelfstandige businessunits, waarbij minder rendabele en niet bij de nieuwe visie passende onderdelen verkocht zijn. ledere businessunit heeft een eigen P\&O-afdeling die tevens met het beheer en de kwaliteit van de opleidingen belast is. ledere businessunit kan zelf trainingen en opleidingen organiseren en inkopen. Daarbij worden zij ondersteund door een centrale afdeling die het gehele jaar vakspecifieke en meer op vaardigheden gerichte opleidingen aanbiedt. Deze opleidingen worden voor een groot deel door externe opleidingsinstituten verzorgd. De deelnemers hebben een brede achtergrond qua opleiding, functie en leeftijd en komen zowel uit de productie- als uit de ondersteunende werkomgeving. De deelname aan een training geschiedt op volgorde van vrijwillige aanmelding, waardoor verondersteld kan worden, dat de trainingsgroepen heterogeen van samenstelling zijn. Het aantal aangeboden cursussen is afhankelijk van de hoeveelheid inschrijvingen en wordt in ieder geval aangeboden, zodra de gewenste groepsgrootte van acht deelnemers is bereikt. $\mathrm{Na}$ de inschrijving zijn de deelnemers (at random) over twee controlegroepen en vier experimentele groepen verdeelt $(N=$ maximaal 8$)$. De opzet was deze aantallen steeds voort te zetten naargelang het aantal inschrijvingen. Schematisch was de opzet van de deelname aan het onderzoek als volgt (figuur 3.1):

Figuur 3.1: Schema selectie-deelnemers

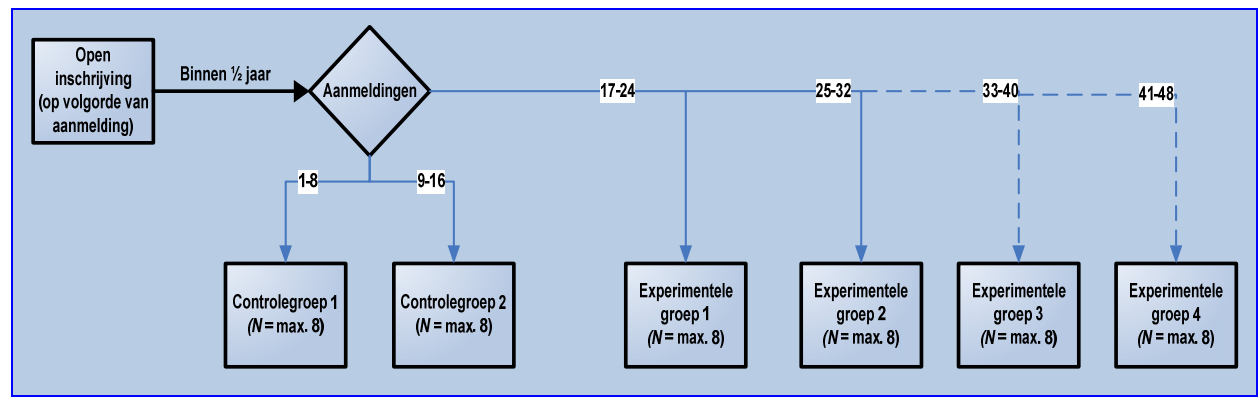

Het doel van de centrale organisatie was om meer inzicht te krijgen in de effectiviteit (rendement) van hun opleidingen. Voor de ontwikkeling van het meetinstrumentarium is rekening gehouden met de aanbevelingen van Fishbein en Ajzen (1980, 2010). Om de potentiële doelgroep zo groot mogelijk te houden, is voor de training 'Effectieve Communicatie' gekozen omdat er voor deze training binnen de organisatie grote belangstelling is. Samen met het hoofd van de centrale opleidingsafdeling en met personeelsfunctionarissen van de diverse businessunits is het onderzoeksdesign opgesteld. Daarbij is het onderzoeksproces volgens de principes uit 'Intervention Mapping' (zoals omschreven door Schaalma et al., 2001; Schaalma \& Kok, 2007 en Bartholomew et al., 2006) in een gestructureerd programma uitgewerkt. 
In de voorfase ('needs assessment') is met de betrokken experts van de organisatie de probleemstelling geformuleerd. Ten eerste wilde de organisatie weten wat mogelijke barrières zijn voor gedragsverandering en de toepassing van het aangeleerde in de praktijk. Ten tweede wilde de organisatie weten wat het effect van de gevolgde cursussen in het algemeen was. Ten derde wilde de organisatie aan het einde van het onderzoek concrete voorstellen hebben over hoe het proces van de training zou kunnen worden aangepast, zodat een hoger effect kan worden behaald.

De uiteindelijke onderzoeksopzet laat zich schematisch als volgt weergeven (figuur 3.2).

Figuur 3.2: Onderzoeksopzet van de training

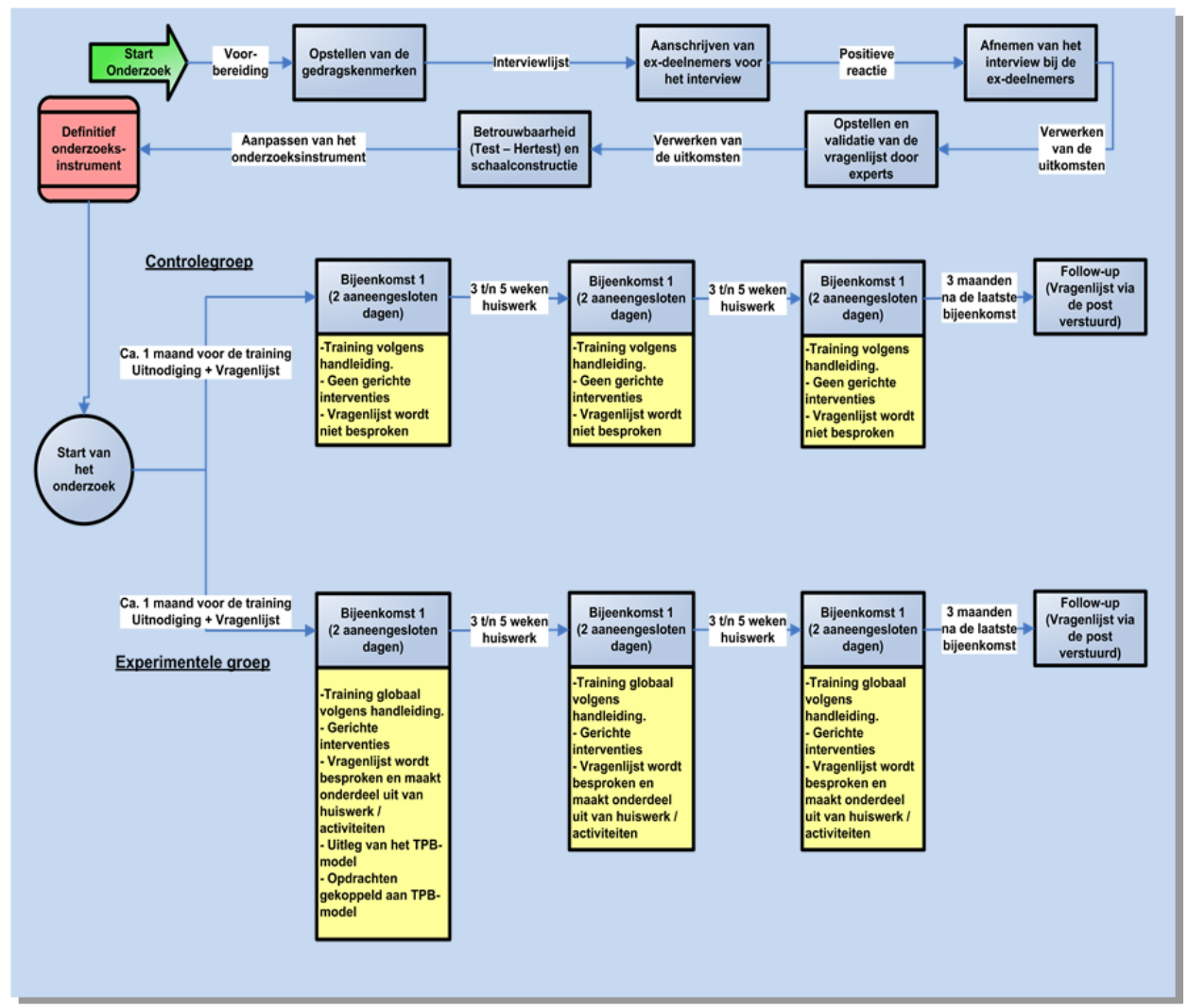

De training bestond uit een schriftelijke voorbereidingsopdracht (zie bijlage 1) en een drietal groepsbijeenkomsten. De inhoudelijke onderwerpen van de training waren:

- Effectieve interactie

- Reflectie op eigen aandeel binnen communicatie

- Waarnemen, interpreteren en evalueren

- Luistervaardigheden

- Alert zijn en afstemmen op gesprekspartners

- Feedback geven en ontvangen

- Verbale en non-verbale communicatie

- Omgaan met blokkerende gedachten 
Voor alle groepen was het materiaal en de opzet uniform van aard. Tijdens de training is met een draaiboek gewerkt, zijn dezelfde oefeningen gehanteerd en heeft de training op een externe locatie plaatsgevonden. Voor de training is de volgende opbouw gehanteerd (tabel 3.1):

Tabel 3.1: Overzicht van de trainingsinhoud (training 'Effectieve Communicatie')

\begin{tabular}{|c|c|c|}
\hline Onderdeel & Inhoud & Doelstelling \\
\hline $\begin{array}{l}\text { Blok 1: } \\
2 \text { dagen aaneengesloten op een } \\
\text { externe locatie }\end{array}$ & $\begin{array}{ll}\text { - } & \text { Kennismaking } \\
\text { - } & \text { Leerdoelenbespreking } \\
\text { - } & \text { Witleg Communicatiemodel } \\
\text { - } & \text { Storingen en ruis in de com- } \\
& \text { municatie } \\
\text { - } & \text { Specifiek en assertief taalge- } \\
& \text { bruik } \\
\text { - } & \text { Zelfonderzoek naar eigen } \\
& \text { referentiekader } \\
- & \text { Non-verbaal gedrag } \\
\text { - } & \text { Adequaat taalgebruik } \\
\text { - } & \text { Actief luisteren } \\
\text { - } & \text { Evaluatie } \\
\text { - } & \text { Actieplan }\end{array}$ & $\begin{array}{ll}\text { - } & \text { Opstellen van concrete } \\
\text { leerdoelen } \\
\text { - } & \text { Inzicht in de verschillende } \\
\text { aspecten van communicatie } \\
\text { - } \quad \text { Inzicht en kennis over versto- } \\
\text { ringen } \\
\text { - } \quad \text { Taal als communicatiemiddel } \\
\text { - } \quad \text { Toepassen van de opgedane } \\
\text { kennis op de eigen persoon } \\
\text { - Opstellen van een leerplan }\end{array}$ \\
\hline $\begin{array}{l}\text { Blok 2: } \\
2 \text { dagen aaneengesloten op een } \\
\text { externe locatie }\end{array}$ & $\begin{array}{l}\text { 1. Terugkoppeling voortgang } \\
\text { 2. Eigen korte presentaties } \\
\text { 3. Roos van Leary } \\
\text { 4. Rollenspellen } \\
\text { 5. Assertiviteit } \\
\text { 6. Functionele analyse van } \\
\text { vermijdingsgedrag } \\
\text { 7. Eigen inbreng } \\
\text { 8. Vergadersituaties } \\
\text { 9. Actieplan } \\
\text { 10. Evaluatie }\end{array}$ & $\begin{array}{l}\text { 11. Inzicht in de eigen voortgang } \\
\text { en leerdoelen } \\
\text { 12. Inzicht en toepassen van } \\
\text { diverse posities in de com- } \\
\text { municatie } \\
\text { 13. Assertief kunnen optreden } \\
\text { 14. Een analyse van het eigen } \\
\text { vermijdingsgedrag kunnen } \\
\text { opstellen } \\
\text { 15. Assertief kunnen vergaderen } \\
\text { 16. Opstellen van een leerplan }\end{array}$ \\
\hline $\begin{array}{l}\text { Blok 3: } \\
1 \text { dag, terugkomdag }\end{array}$ & $\begin{array}{l}\text { 17. Terugkoppeling voortgang } \\
\text { 18. Kritiek geven/ontvangen } \\
\text { 19. Feedback geven aan elkaar } \\
\text { 20. Afsluiting training } \\
\text { 21. Evaluatie } \\
\text { 22. Contract sluiten met jezelf }\end{array}$ & $\begin{array}{l}\text { 23. Inzicht in de eigen voortgang } \\
\text { en leerdoelen } \\
\text { 24. Kritiek kunnen geven en } \\
\text { ontvangen } \\
\text { 25. Feedback geven en ontvan- } \\
\text { gen } \\
\text { 26. Leerplan opstellen }\end{array}$ \\
\hline
\end{tabular}

Omdat de doelstellingen van de training globaal geformuleerd waren en in mindere mate op specifiek gedrag gericht geformuleerd, zijn met een aantal personeelsfunctionarissen en trainers de belangrijkste gedragsdeterminanten van de training geinventariseerd. Een groep bestaande uit twee personeelsfunctionarissen en twee trainers van het opleidingsinstituut hebben vervolgens de belangrijkste gedragsdeterminanten geselecteerd, van waaruit een semigestructureerd interview is samengesteld, dat nauw aansloot bij de uitgangspunten van de 'Reasoned Action Approach'. Voor de ontwikkeling van de vragenlijst is gebruik gemaakt van aanbevelingen en handreikingen uit eerdere onderzoeken (waaronder Schaalsma, 1993; Empelen et al., 2001; Schaalsma, Kok en Meertens, 2007 en Fishbein \& Ajzen, 2010). 
Het doel van de ontwikkelde vragenlijst was om gedrag te specificeren, de belangrijkste belemmerende en bevorderende factoren te identificeren, zicht te krijgen op betrokken randvoorwaarden en de in de 'Reasoned Action Approach' gehanteerde factoren aan te scherpen betreffende de specifieke doelgroep.

In het totaal zijn er 108 oud-deelnemers aangeschreven, die reeds hadden deelgenomen aan de training, waarvan 51 personen $(47,2 \%)$ positief hebben gereageerd. In een periode van vier maanden is bij deze personen het ontwikkelde semigestructureerd interview afgenomen (zie bijlage 2). Daarin zijn vooral vragen gesteld over het gedrag, de 'attitude', de mogelijke drempels, de randvoorwaarden, de 'ervaren controle' en de 'ervaren norm'. Ook is onderzocht wat hun ervaringen vóór, tijdens en na de cursus 'Effectieve Communicatie' waren, en hoe de in de 'Reasoned Action Approach' omschreven variabelen in de praktijk tot uiting kwamen. Behalve een verduidelijking van de te onderzoeken criteria gaven de interviews ook inzicht in randvoorwaardelijke factoren. Zo gaven de meeste deelnemers aan al in het begin van de cursus erg gemotiveerd geweest te zijn en dat het tijd nemen om met het nieuwe gedrag te kunnen oefenen in belangrijke mate bijdroeg tot het succes van de training. Verder kwam uit de interviews naar voren, dat door de complexiteit van de in de cursus besproken gedragscomponenten het moeilijk is om eenduidige gedragscriteria - zoals Fishbein en Ajzen (1975) die hanteren - te formuleren (zie kader 3.1). De meest gebruikte omschrijvingen waren verzamelbegrippen voor een aantal gedragingen, zoals 'ik heb een actieve luisterhouding' of 'ik geef feedback aan anderen'. Pas na doorvragen en het beschrijven van deelaspecten konden bruikbare gedragsbeschrijvingen geformuleerd worden. De 'attitude' en 'ervaren norm' konden daarentegen wel duidelijk worden benoemd.

Kader 3.1

In de genoemde training komen begrippen zoals assertiviteit, actief luisteren, feedback geven, kritiek geven (ontvangen) aan bod. Echter, een dergelijk begrip laat zich vertalen naar een aantal gedragingen die door iedereen ook weer anders geïnterpreteerd worden. Voor de effectiviteit van de training is het dus noodzakelijk om deze afzonderlijke gedragingen van een dergelijk verzamelbegrip inzichtelijk te maken. Conform de aanbevelingen van Fishbein en Ajzen zijn plaats, tijd, doel en context belangrijke elementen. Voor eenvoudige gedragingen is dat relatief eenvoudig. Als ik bijvoorbeeld minder wil snoepen op het werk, zou mijn voornemen kunnen zijn, dat ik iedere ochtend, als ik tussen 8.30 en 9.00 uur bij onze secretaresse langsga, geen snoepje uit de snoeppot meer pak. Voor assertiviteit is dat al minder eenvoudig. Ten eerste heeft het te maken met verbale en non-verbale gedragingen, stemvolume, houding en zijn vooral context en plaats van belang voor hoe ik assertiviteit tot uiting laat komen. Het is dus van belang de facetten van assertiviteit te benoemen of een gemeenschappelijk beeld te creëren, zodat het voor iedereen duidelijk is, wat ermee bedoeld wordt.

Tijdens de bespreking van deze uitkomsten is met de personeelsfunctionarissen van de diverse businessunits uiteindelijk besloten de kenmerken met de grootste consensus tot één criterium samen te voegen (bijvoorbeeld feedback geven, dat uit diverse gedragsaspecten bestaat). De deelnemers hebben dan tijdens de cursus zelf de mogelijkheid om te laten bepalen hoe 'specifiek' zij deze in termen van het doel, de situatie of 
context, het tijdstip en de plaats in hun leerdoelen willen formuleren. Hiervoor wordt aan het einde van iedere bijeenkomst een persoonlijk leerplan opgesteld. Ook bij de controlegroep is een persoonlijk leerplan opgesteld, dat niet specifiek verwijst naar de in het 'Reasoned Action Model' gehanteerde criteria. Uiteindelijk zijn de uitkomsten van de interviews vertaald naar een zelfevaluatie vragenlijst, die aansloot bij de in de 'Reasoned Action Approach' beschreven principes van Fishbein en Ajzen (2010). Deze gaan ervan uit, dat kan worden aangenomen dat een schriftelijke zelfbeoordeling van gedragsvoornemens een goede voorspeller is voor het uiteindelijke gedrag (Fishbein \& Ajzen, 2010; p. 37 ff). Daarbij is het vooral van belang, dat alle deelnemers dezelfde opvatting hebben over de gekozen gedragscategorieën. Bij de controlegroep bleef het bij algemene beschrijvingen. Bij de interventiegroep zijn de leerdoelen conform Fishbein en Ajzen (2010) aangescherpt en met de deelnemer besproken.

Bij het ontwerp van de vragenlijstis gekozen voor dichotome schalen, omdat bij onderzoeken naar gedrag een dergelijke vorm als antwoordkeuze de meest betrouwbare uitkomsten biedt. Hiervoor dienen deze zo stellig en duidelijk mogelijk te worden geformuleerd. In dat verband merken Fishbein en Ajzen op, dat beschrijvingen zoals 'geheel wel - geheel niet' of 'altijd - nooit' de beste resultaten opleveren. Deze bevindingen zijn uitgangspunt geweest bij de ontwikkeling van de vragenlijst. De conceptvragenlijst bestond uiteindelijk uit 35 onderzoeksvragen, 6 algemene vragen (demografische gegevens) en 1 open vraag. Voor de onderzoeksvragen is conform de aanbevelingen van Fishbein en Ajzen gebruik gemaakt van een stelling die vervolgens op een 5-punt schaal kon worden beantwoord. Een voorbeeld:

Stelling: Ik ben tevreden over de aansturing door mijn direct leidinggevende

Antwoord: geheel eens $\square-\square-\square-\square-\square$ geheel oneens

Stelling: Ik geef feedback aan anderen

Antwoord: altijd $\square-\square-\square-\square-\square$ nooit

Conform de onderzoeksopzet is de conceptvragenlijst vervolgens aan de 18 experts (trainers van het betrokken opleidingsbureau en P\&O-medewerkers) voorgelegd. In drie bijeenkomsten zijn die vragen geselecteerd, welke tenminste door $80 \%$ van de experts aan de beoogde schaal toegewezen werden. Twee van de 35 onderzoeksvragen voldeden niet aan dit criterium, maar deze werden, gezien het beperkt aantal vragen, bij het verdere onderzoek toch meegenomen. De vragenlijst is vervolgens bij 14 personen uit de doelgroep getoetst op betrouwbaarheid door de testhertestbetrouwbaarheid te berekenen (gepaarde $t$-test) met een interval van vier weken tussen de eerste en tweede afname. De uitkomsten daarvan geven voor de meeste vragen een hoge stabiliteit weer. Bij 30 onderzoeksvragen werd geen significant verschil aangetroffen tussen de $1^{\mathrm{e}}$ en de $2^{\mathrm{e}}$ meting. Bij vijf onderzoeksvragen werd wel een significant verschil aangetroffen $(p<.05)$. De vraag rijst of de in het onderzoeksmodel opgestelde schaalindeling ook in de praktijk kan worden aangetroffen. In het algemeen is het wenselijk om variabelen of schalen met behulp van een factoranalyse te identificeren. Gezien de geringe steekproefomvang $(N=14)$ werd echter de voorkeur gegeven aan een analyse waarbij Cronbach's $\alpha$ berekend werd over de schalen zoals die a priori ontwikkeld waren. 
Daarbij werd met name gekeken naar de interne consistentie van de schaal, alsmede naar de mate waarin de vragen onderling positief correleerden (binnen een bepaalde schaal ongeacht de hoogte). De uitkomsten laten voor de gekozen schaalindeling een hoge $\alpha$ zien voor zowel de $1^{\mathrm{e}}$ meting, de $2^{\mathrm{e}}$ meting en voor beide metingen gezamenlijk, alpha varieert van .66 tot .82 (mediaan .75). Hierbij werden 3 vragen aangetroffen die de betrouwbaarheid binnen de betreffende schaal negatief beïnvloedden. Bij het vaststellen van de definitieve vragenlijst zijn de volgende criteria gehanteerd: (1) De vragen werden door tenminste $80 \%$ van de experts toegewezen aan de beoogde schaal, (2) de vragen zijn over langere tijd onder gelijke omstandigheden redelijk stabiel in de testhertest beoordeling ( $p>$.05), (3) Cronbach's $\alpha$ bedroeg voor de uiteindelijke schaal tenminste .70, en (4) alle items binnen de schaal moesten positief met de andere items correleren. Een overzicht van de uitkomsten is in de volgende tabel 3.2 weergegeven.

\section{Tabel 3.2: Resultaten van de vragenlijst in ontwikkeling}

\begin{tabular}{|c|c|c|c|c|}
\hline & $\begin{array}{l}\text { Expert } \\
\text { validatie } \\
(N=18)\end{array}$ & $\begin{array}{c}\text { T-waarde } \\
\text { Test- } \\
\text { Hertestbetrouw- } \\
\text { baarheid } \\
(N=14)\end{array}$ & $\begin{array}{c}\text { Cronbach's } \alpha \\
\text { meting } 1 \& 2 \\
(N=14)\end{array}$ & $\begin{array}{c}\text { Definitief } \\
\text { uit de } \\
\text { vragenlijst } \\
\text { verwijderd }\end{array}$ \\
\hline ATTITUDE & & & $\alpha=0.76$ & \\
\hline $\begin{array}{l}\text { Met een effectieve communicatie kan ik mijn werkprestatie verbe- } \\
\text { teren }\end{array}$ & $83.3 \%$ & 1.32 & .65 & \\
\hline Effectieve communicatie heeft voordelen voor mijn werk & $94.4 \%$ & 0.39 & .67 & \\
\hline $\begin{array}{l}\text { Het heeft voor mij voordelen om mijn eigen gedrag met EC in de } \\
\text { toekomst te veranderen }\end{array}$ & $100 \%$ & 0.15 & .73 & \\
\hline Het is goed om je eigen communicatie te willen verbeteren & $55.6 \%$ & 0.71 & .75 & $* 3$ \\
\hline ERVAREN CONTROLE & & & $\alpha=0.77$ & \\
\hline $\begin{array}{l}\text { Ik kan zelf een actieve bijdrage leveren aan effectieve communica- } \\
\text { tie }\end{array}$ & $94.4 \%$ & 0.00 & .63 & \\
\hline $\begin{array}{l}\text { Ik heb voldoende kennis om aan de training een bijdrage te kunnen } \\
\text { leveren }\end{array}$ & $88.9 \%$ & -1.00 & .60 & \\
\hline Ik heb voldoende randvoorwaarden om effectief te communiceren & $100 \%$ & 0.15 & $.86 * 2$ & $* 3$ \\
\hline Ik ben zelf verantwoordelijk voor een goede communicatie & $88.9 \%$ & -0.69 & .72 & \\
\hline Ik kan in mijn werk met ander gedrag experimenteren & $83.3 \%$ & -1.32 & .73 & \\
\hline SOCIALE NORM & & & $\alpha=0.73$ & \\
\hline Mijn leidinggevende stimuleert mij in het kader van deze training. & $94.4 \%$ & -0.37 & .71 & \\
\hline $\begin{array}{l}\text { Ik ben tevreden over de aansturing door mijn direct leidinggeven- } \\
\text { de. }\end{array}$ & $83.3 \%$ & 0.56 & .68 & \\
\hline $\begin{array}{l}\text { Ik word door anderen gewaardeerd als ik mij inzet voor een goede } \\
\text { communicatie. }\end{array}$ & $83.3 \%$ & 1.17 & .72 & \\
\hline $\begin{array}{l}\text { Mijn direct leidinggevende staat positief tegenover deze training } \\
\text { (EC). }\end{array}$ & $88.9 \%$ & 0.00 & .68 & \\
\hline Ik ontvang uit mijn directe omgeving waardering voor mijn werk. & $94.4 \%$ & -0.56 & .71 & \\
\hline $\begin{array}{l}\text { Mijn collega's voelen zich verantwoordelijk voor een goede com- } \\
\text { municatie. }\end{array}$ & $88.9 \%$ & 0.81 & 68 & \\
\hline $\begin{array}{l}\text { Mijn directe collega staat positief tegenover effectieve communica- } \\
\text { tie. }\end{array}$ & $88.9 \%$ & $-2.51 * 1$ & .71 & $* 3$ \\
\hline $\begin{array}{l}\text { Mijn collega's hebben een positieve bijdrage aan mijn communica- } \\
\text { tie. }\end{array}$ & $88.9 \%$ & -0.43 & $.79 * 2$ & $* 3$ \\
\hline $\begin{array}{l}\text { Mijn partner (thuis) staat positief t.o.v. mogelijke veranderingen in } \\
\text { het werk. }\end{array}$ & $88.9 \%$ & -0.96 & .72 & \\
\hline Ik hoor anderen waardering voor hun werk te geven. & $83.3 \%$ & $-2.28 * 1$ & .66 & $* 3$ \\
\hline Ik maak met de organisatie afspraken over mijn persoonlijke ont- & $88.9 \%$ & -1.47 & .68 & \\
\hline
\end{tabular}




\begin{tabular}{|c|c|c|c|c|}
\hline INTENTIE (RESULTAAT) & & & $\alpha=0.75$ & \\
\hline Ik word door mijn omgeving op mijn communicatie aangesproken. & $55.6 \%$ & $-2.88 * 1$ & $.78^{* 2}$ & $* 3$ \\
\hline $\begin{array}{l}\text { Mijn verschillende werkzaamheden en resultaten zijn duidelijk } \\
\text { omschreven. }\end{array}$ & $88.9 \%$ & -1.38 & .70 & \\
\hline Effectieve communicatie geeft mij een positief gevoel. & $94.4 \%$ & $-3.71 * 1$ & .74 & $* 3$ \\
\hline Ik heb actieve (luister)houding in de interactie met anderen. & $94.4 \%$ & 0.48 & .74 & \\
\hline Ik geef feedback aan anderen. & $100 \%$ & 0.00 & .74 & \\
\hline Ik ga met plezier naar mijn werk. & $83.3 \%$ & -1.15 & .73 & \\
\hline Ik heb een actieve luisterhouding. & $100 \%$ & 0.00 & .71 & \\
\hline Ik sta open voor de mening van anderen. & $88.9 \%$ & 0.81 & .70 & \\
\hline $\begin{array}{l}\text { Ik heb duidelijke ontwikkelafspraken (Leerdoelen) over EC ge- } \\
\text { maakt. }\end{array}$ & $88.9 \%$ & -1.38 & .73 & \\
\hline Ik geef op een productieve manier kritiek op anderen. & $100 \%$ & 0.00 & .71 & \\
\hline Er worden goede afspraken over het werk gemaakt. & $100 \%$ & 0.00 & .74 & \\
\hline $\begin{array}{l}\text { Ik neem eigen initiatief in het werk om de nodige dingen op te } \\
\text { pakken. }\end{array}$ & $88.9 \%$ & 2.12 & .73 & \\
\hline Mijn collega's staan open voor de mening van anderen. & $88.9 \%$ & -0.56 & .70 & \\
\hline Er wordt duidelijk gecommuniceerd. & $88.9 \%$ & $5.63 * 1$ & .75 & $* 3$ \\
\hline $\begin{array}{l}\text { Mijn collega's nemen initiatief in het werk om de nodige dingen op } \\
\text { te pakken. }\end{array}$ & $88.9 \%$ & -1.47 & .73 & \\
\hline
\end{tabular}

Uiteindelijk zijn van de oorspronkelijke 35 onderzoeksvragen in totaal 8 items uit de vragenlijst verwijderd.

De uiteindelijke vragenlijst kende de volgende opzet:

'Attitude'. De 'attitude' ten aanzien van effectieve communicatie werd gemeten met drie items. De items werden door $83 \%$ tot $100 \%$ van de 18 experts aan deze schaal toegewezen. De gemiddelde scores op deze items verschilden niet significant over de twee metingen ( $p$ 's > .05, wat suggereert dat de test-hertestbetrouwbaarheid (stabiliteit) van deze items in orde was) en de betrouwbaarheid van de schaal (Cronbach's $\alpha$ ) bedroeg 0.76 .

'Ervaren controle'. over het gewenste gedrag werd gemeten met vier items. De items werden door $83 \%$ tot $94 \%$ van de beoordelaars aan deze schaal toegewezen, de scores op de items was stabiel over de tijd (test-hertestbetrouwbaarheid van $p>.05$ ), en Cronbach's $\alpha$ was 0.77 .

'Ervaren norm'. Dit begrip werd gemeten met acht items. Deze items werden door $83 \%$ tot $94 \%$ van de beoordelaars aan deze schaal toegewezen, met een testhertestbetrouwbaarheid van $p>.05$ en een Cronbach's $\alpha$ van 0.73 .

'Gedragsintentie'. De intentie om het in de training geleerde gedrag toe te passen, werd gemeten met twaalf items. Deze items werden door $83 \%$ tot $100 \%$ van de beoordelaars aan deze schaal toegewezen, met een test-hertestbetrouwbaarheid van $p>.05$ en een Cronbach's $\alpha$ van 0.75 .

\subsubsection{Toepassing van het instrument}

De definitieve vragenlijst (zie bijlage 3 ) werd, samen met de uitnodiging om aan de training deel te nemen en met een voorbereidingsopdracht en uitleg over het onderzoek, naar alle toekomstige deelnemers gestuurd. Aan het begin van iedere bijeenkomst is steeds dezelfde vragenlijst door alle deelnemers ingevuld. Voor de followupmeting is de vragenlijst per post verstuurd. Bij de groep met een maatwerkpro- 
gramma kregen de trainer en de deelnemers informatie over de uitkomsten van iedere meting. Tevens kreeg men oplossingsrichtingen aangeboden, die waren gebaseerd op de 'Reasoned Action Approach'. Hiervoor hebben twee trainers en een personeelsfunctionaris de uitkomsten van iedere vragenlijst kort geanalyseerd en is er per deelnemer een advies opgesteld. Dit advies is vervolgens door trainer meegenomen bij het opstellen en bespreken van het persoonlijk leerplan met de individuele deelnemer. In de regel waren de adviezen als volgt:

- Bij lage 'attitude' was het advies om meer te informeren over de gevolgen van negatief gedrag, inzicht te geven en aan te tonen dat oud gedrag niet tot een gewenst resultaat leidt. Maar ook in gesprek gaan met leidinggevende, personeelsfunctionaris of collega over de eigen twijfels.

- Het advies bij een lage 'ervaren norm' was erop gericht in gesprek te gaan met de omgeving, enthousiaste oud-deelnemers aan deelnemers te koppelen, maar deze ook weerbaarder te maken. Ook een 'coach' binnen de eigen omgeving opzoeken en het onderwerp tijdens een vergadering bespreekbaar te maken, waren mogelijke oplossingen.

- Voor 'ervaren controle' lagen de adviezen vooral op het vlak van kennis vergroten, vaardigheden en hulpmiddelen aanbieden, waarbij ook gebruik is gemaakt van videofeedback. Maar ook ontspanningsoefeningen, een cursus retoriek/theater en doelgericht toepassen van RET waren hierbij hulpmiddelen.

Waar nodig werden de leidinggevenden en de omgeving van de deelnemers bij de leerdoelen betrokken. De inhoud van de training kon binnen de voorgegeven thema's worden aangepast op basis van de aangetroffen resultaten en was direct gekoppeld aan de persoonlijke lesonderdelen. De groep met een standaardprogramma kreeg geen oplossingsrichtingen aangeboden ten aanzien van de uitkomsten van de vragenlijst en voor deze deelnemers was het leerplan veel meer gebaseerd op de onderdelen die in de cursus aan bod zijn gekomen. Het essentiële verschil met de maatwerkgroep is, dat bij de standaardgroep geen verband werd gelegd tussen (en ook geen discussie binnen de groep werd gevoerd over) de uitkomsten van het (voor)onderzoek en de leerdoelen van de deelnemers. Evenmin werd een specifiek op de 'Reasoned Action Approach' gebaseerd leerplan opgesteld. Wel moet nadrukkelijk worden opgemerkt, dat ook de controlegroep, die het standaardprogramma volgde, een korte terugkoppeling kreeg over de hoogte van hun scores op de vragenlijst. Het verschil lag vooral hierin, dat er niets met de uitkomsten is gedaan en geen verdere uitleg is gegeven. Hiermee is ook voorkomen, dat deelnemers uit dezelfde businessunit (dus mogelijk collega's) het gevoel kregen een verschillend programma te volgen. Er was immers de mogelijkheid dat de deelnemers onderling contact hadden.

Ten behoeve van het definitieve onderzoek werden 6 trainingsgroepen aselect in volgorde van aanmelding geselecteerd. Vier daarvan (totale $N=35$ ) ontvingen het 'maatwerkprogramma', de overige twee groepen $(N=19)$ kregen een standaardprogramma aangeboden. In beide gevallen werden de deelnemers vier maal ondervraagd, respectievelijk aan het begin van iedere trainingsbijeenkomst (de interval tussen de trainingsbijeenkomsten was drie tot maximaal vijf weken) en drie maanden na de laatste bijeenkomst. Door ziekte, onvolledig ingevulde vragenlijsten en non-respons op de follow-up meting waren bij 15 deelnemers niet alle data over de vier metingen aanwezig. In totaal zijn de gegevens van 39 deelnemers in dit onderzoek verwerkt: 25 deelnemers bevonden zich in de groep met een maatwerkprogramma, de overige 14 deelnemers ontvingen een standaardprogramma. 
Met een Chi-Kwadraattoets en een variantieanalyse werd onderzocht of de onderzoeksgroepen van elkaar verschilden met betrekking tot leeftijd, geslacht, opleiding, functie en burgerlijke staat. Zulks bleek niet het geval te zijn (zie tabel 3.3). De gemiddelde leeftijd was 36 jaar, 52\% van de deelnemers was vrouwelijk en $75 \%$ was getrouwd of samenwonend. Van de deelnemers hadden er 4 lager onderwijs als hoogste opleiding, 21 lager beroepsonderwijs, 19 hoger beroepsonderwijs en 9 deelnemers hadden een universitaire achtergrond.

Tabel 3.3: Analyse op de algemene gegevens tussen de onderzoeksgroepen

\begin{tabular}{lcrrrrr}
\hline Variantieanalyse & $\boldsymbol{N}$ & Missing & $d f$ & Mean Square & $\boldsymbol{F}$ & $\boldsymbol{p}$-waarde \\
\hline Leeftijd & 36 & 3 & 5 & 37,163 & 1,212 &, 327 \\
\hline Chi-kwadraat toets & $\boldsymbol{N}$ & Missing & $d f$ & Pearson Chi-Kwadraat & Significantie \\
\hline Burgerlijke staat & 38 & 1 & 15 & 13,27 &, 582 \\
\hline Geslacht & 38 & 1 & 5 & 4,3 &, 507 \\
\hline Opleiding & 37 & 2 & 15 & 11,32 &, 730 \\
\hline Functie & 38 & 1 & 10 & 8,20 &, 609 \\
\hline$(p<.05=$ significant verschil) & & & & & \\
\hline
\end{tabular}

Door het relatief klein aantal deelnemers per trainingsgroep stijgt de kans op misinterpretatie van de gevonden uitkomsten. Voor de verdere statistische verwerking is het wenselijk dat de groepsomvang zo groot mogelijk is. Derhalve is onderzocht of voor de uiteindelijke berekeningen de separate trainingsgroepen als één onderzoeksgroep konden worden gezien binnen hun eigen trainingsprogramma. Daarbij was het uitgangspunt dat de trainingsgroepen binnen hun programma (standaard, maatwerk) over de vier meetmomenten niet significant van elkaar zouden mogen verschillen. Deze aanname is met behulp van een multivariate variatieanalyse (MANOVA) getoetst. Voor de twee trainingsgroepen met een standaardprogramma is voor alle variabelen en over de vier meetmomenten geen significant verschil aangetroffen, $F(1,13)=3.18, p>.79$. Ook voor de vier trainingsgroepen met een maatwerkprogramma is op de 4 meetmomenten geen significant verschil aangetroffen, $F(3,24)=1.4, p>.91$. Een groepseffect binnen de onderzoeksgroepen kan dus met grote waarschijnlijkheid worden uitgesloten. Derhalve kan voor de verdere berekeningen van twee onderzoeksgroepen worden uitgegaan. De aanname dat een maatwerkprogramma een sterker en langduriger effect op het beoogde gedrag zal hebben dan een standaardprogramma werd in eerste instantie getoetst door middel van een 2 (Groep: maatwerk vs. standaardtraining) x 4 (Tijd; voor, tijdens, na en follow up) variantieanalyse met herhaalde metingen op Tijd, voor elk van de vier criteriumvariabelen ('attitude', 'ervaren controle', 'ervaren norm' en 'gedragsintentie') afzonderlijk. Wanneer deze analyse aangaf, dat er een multivariaat hoofd- of interactie-effect was, werd dit effect verder uitgewerkt door middel van univariate variantieanalyses. Tenslotte werd via lineaire regressieanalyse de verklarende waarde van de drie criteriumvariabelen op de 'gedragsintentie' berekend (verklarende waarde van 'attitude', 'ervaren controle', 'ervaren norm' op de 'gedragsintentie'). 


\subsubsection{Resultaten}

Een eerste vergelijking van de somscores op de vier te onderzoeken variabelen tussen de groep met maatwerkprogramma en de groep met een standaardprogramma laat op het eerste gezicht een klein maar duidelijk verschil zien in de ontwikkeling van de onderzochte variabelen gedurende de vier metingen. Voor een goede weergave van het verloop binnen de onderzoeksgroepen zijn de gemiddelden omgezet in somscores en zijn deze in grafiek 3.1 weergegeven.

Grafiek 3.1: Relatieve scores over alle vier metingen
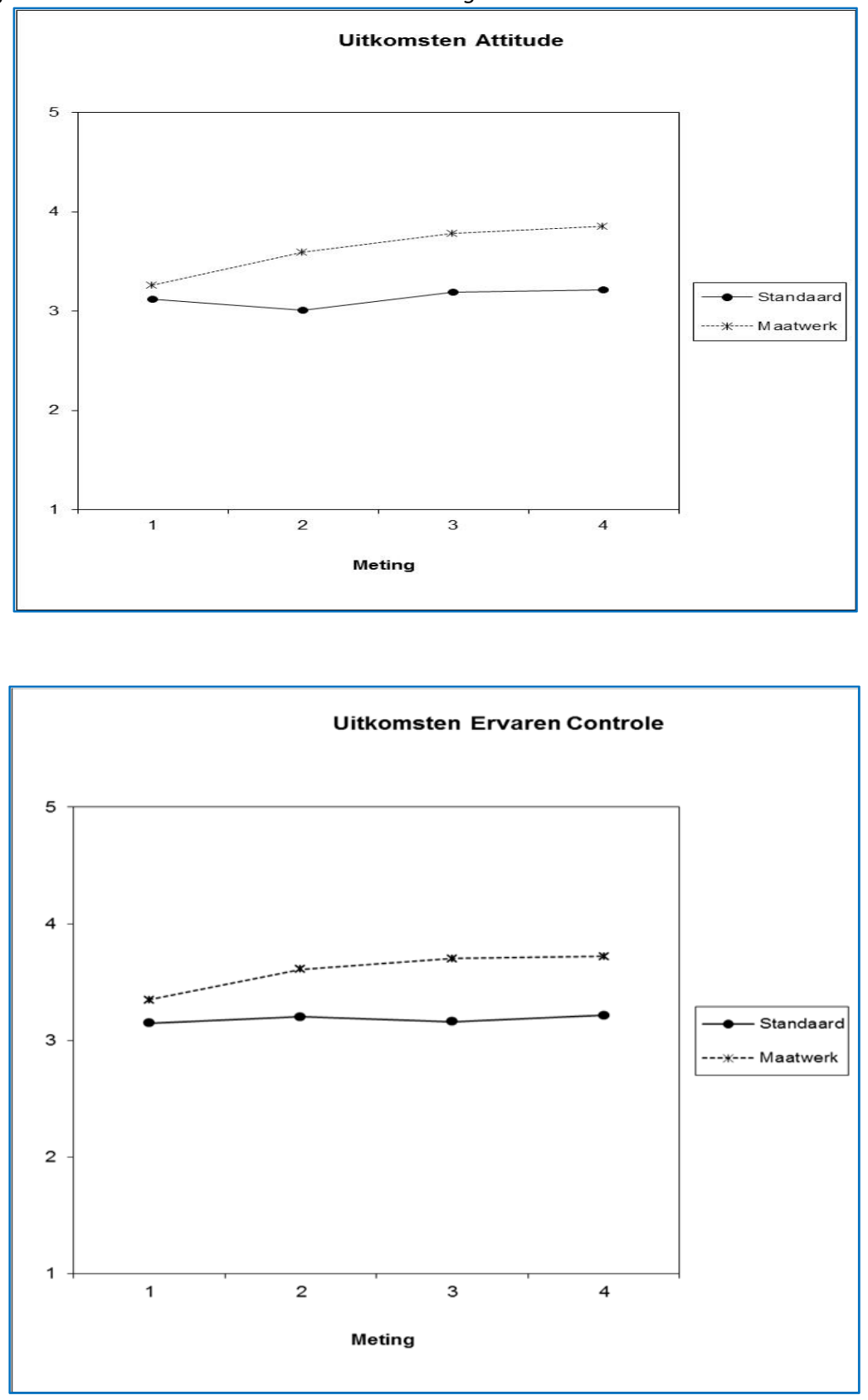

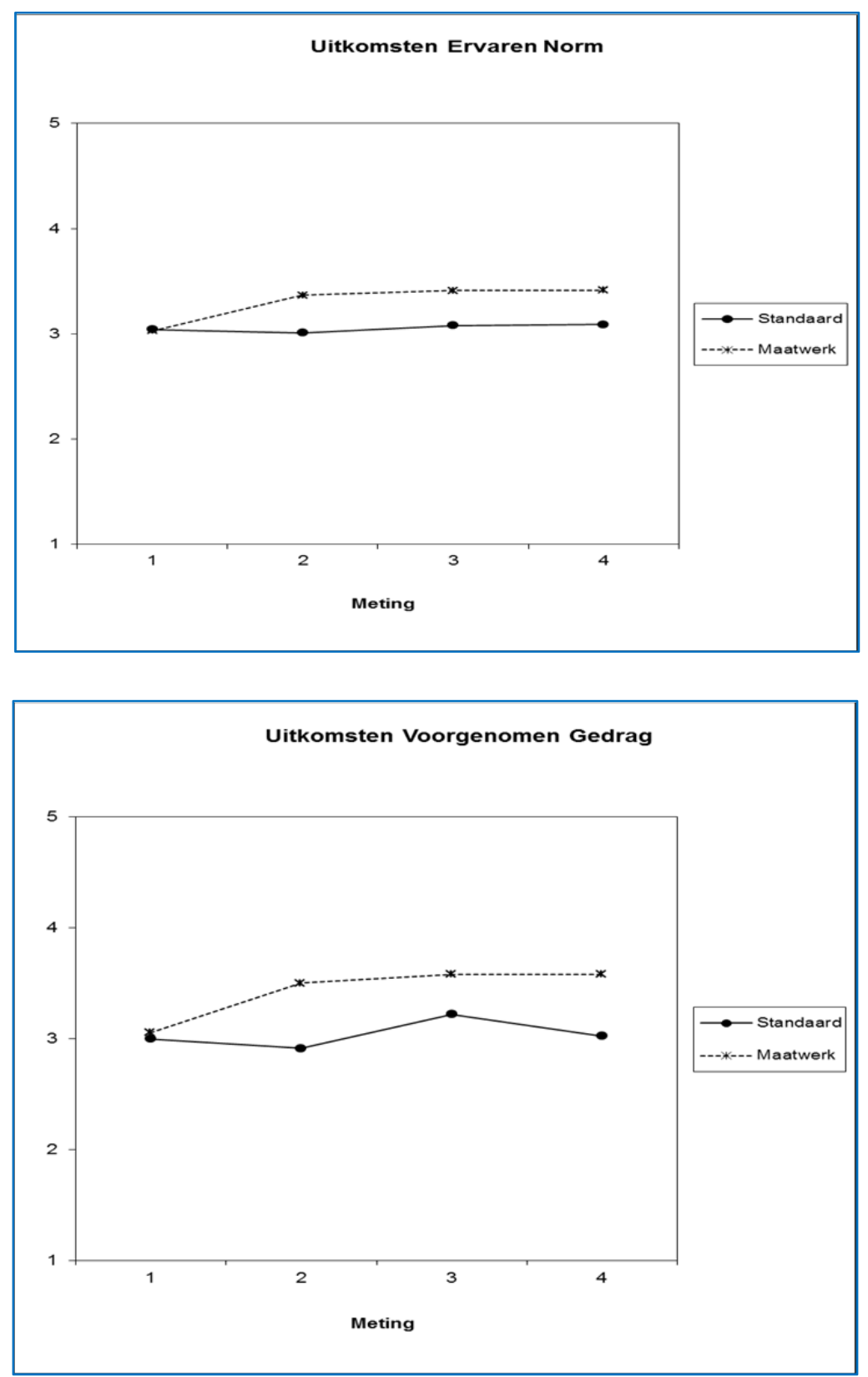

Bij de groep met een standaardprogramma is voor geen van de vier criteriumvariabelen een ontwikkeling waar te nemen. Bij de groep met een maatwerkprogramma echter zijn op een aantal variabelen wel verschillen tussen de follow-up meting en de voormeting aangetroffen. Voor alle vier variabelen is er sprake van een stijging tussen meting 1 en meting 2 . In de daaropvolgende metingen vlakt de stijging af. Op het eerste gezicht lijkt er dus een verband te zijn tussen type training en tijd. 
Deze indruk wordt bevestigd door vier Tijd x Groep variantieanalyses (een per criteriumvariabele), waarin verschillen in zowel de hoofdeffecten van Tijd en Groep als de Tijd $x$ Groep interactie aangetroffen worden (tabel 3.3).

Tabel 3.4: Hoofdeffecten van Tijd en Groep

( $F$-waarden voor de effecten van Tijd, Groep en Tijd x Groep ${ }^{\text {a }}$ )

\begin{tabular}{lrrrr}
\hline Effect & Attitude & Ervaren Norm & Ervaren Controle & Gedragsintentie \\
\hline$F($ Tijd $)$ & $8.05^{* *}$ & $4.84^{* *}$ & $3.02^{*}$ & $17.70^{* *}$ \\
\hline$F($ Groep $)$ & $14.00^{* *}$ & $15.01^{* *}$ & $19.29^{* *}$ & $26.13^{* *}$ \\
\hline$F($ Tijd $x$ Groep $)$ & $4.49^{* *}$ & $4.81^{* *}$ & $1.56^{*}$ & $23.55^{* *}$ \\
\hline${ }^{\mathrm{a}} \mathrm{NB}$ Alle vergelijkingen hebben $(3,35)$ vrijheidsgraden & & & \\
\hline & & & \\
\hline
\end{tabular}

Univariate follow-upanalyses laten zien dat er op tijdstip een (vóór aanvang van de training) geen verschil is tussen de onderzoeksgroepen op alle variabelen uit het 'Reasoned Action Model', alle $F(1,38)<2.12$, alle $p$ 's $>.05$. Daarentegen worden voor alle latere metingen voor alle vier variabelen verschillen tussen de maatwerk- en de standaardgroep aangetroffen, alle $F(1,38)>11.15$, alle $p^{\prime} s<.01$. In de standaardgroep worden geen hoofdeffecten van Tijd aangetroffen, alle $F(3,11)<4.96$, alle $p$ 's $>.05$. Bij de maatwerkgroep wordt echter voor alle variabelen een hoofdeffect van Tijd aangetroffen, alle $F(3,22)>3.61$, alle $p$ 's $<.05$. Op basis van deze gegevens kan worden aangenomen, dat de uitgangspositie voor alle deelnemers dezelfde was en dat verschillen tussen de groep met een maatwerkprogramma en de groep met een standaardprogramma aan de interventies zouden kunnen worden toegeschreven. Grafiek 3.1 laat verder zien, dat de verschillen tussen de twee groepen bij de laatste meting (drie maanden na afloop van de training) ongeveer even groot zijn als op Tijdstip 3, wat betekent dat het effect van de maatwerkgroep ook na verloop van tijd nog meetbaar was in tegenstelling tot de controlegroep met een standaardprogramma. Onze aanname dat een volgens de principes van IM ontwikkelde maatwerk communicatietraining meer effect op het beoogde gedrag zal hebben dan een standaardprogramma wordt door deze uitkomsten ondersteund.

Als aanvulling op de variantieanalyses was het ook interessant te onderzoeken in welke mate de drie variabelen van het 'Reasoned Action Model' ('attitude', 'ervaren norm' en 'ervaren controle') van invloed zijn op de 'intentie' tot gedragsverandering. De uitkomst daarvan geeft een indicatie van de mate waarin de in dit onderzoek gebruikte vragenlijst verklarende waarde heeft voor de 'intentie' van de deelnemers om het bedoelde gedrag te gaan vertonen, hetgeen het gebruik van de 'Reasoned Action Approach' als theoretisch raamwerk van onze training zou rechtvaardigen. Deze vraag is met behulp van een lineaire regressie getoetst. Hiervoor zijn de variabelen uit het 'Reasoned Action Model' ('attitude', 'ervaren controle' en 'ervaren norm') opgenomen als voorspellers van 'intentie'. Daarnaast werd onderzocht of deelname aan een specifiek trainingsprogramma invloed heeft op deze uitkomst. 
Tabel 3.5: Regressieanalyse over de 4 meetmomenten

\begin{tabular}{|c|c|c|c|c|c|c|c|c|}
\hline \multirow[b]{2}{*}{ Effect } & \multicolumn{2}{|c|}{ Meting 1} & \multicolumn{2}{|c|}{ Meting 2} & \multicolumn{2}{|c|}{ Meting 3} & \multicolumn{2}{|c|}{ Meting 4} \\
\hline & Variabelen & +Groep & Variabelen & +Groep & Variabelen & +Groep & Variabelen & +Groep \\
\hline$R$ & .36 & .36 & .66 & .76 & .50 & .59 & .58 & .74 \\
\hline$F$ & $1.72^{* a}$ & $1.29^{* b}$ & $8.85^{* * a}$ & $11.34^{* * b}$ & $3.97^{* a}$ & $4.66^{* * b}$ & $6.03^{* * a}$ & $10.03^{* * b}$ \\
\hline$R^{2}$ & .13 & .13 & .44 & .58 & .25 & .35 & .34 & .56 \\
\hline \multicolumn{9}{|c|}{$*=p<.05, * *=p<.01$} \\
\hline \multicolumn{9}{|c|}{${ }^{a}$ Deze $F$-waarde heeft $(3,35)$ vrijheidsgraden } \\
\hline
\end{tabular}

De uitkomsten van de regressieanalyse (tabel 3.4) laten een matige verklarende invloed op het gedragsvoornemen zien. Opvallend is dat 'ervaren norm', 'attitude' en 'ervaren controle' ten tijde van de eerste meting relatief zwak samenhangen met de 'gedragsintentie' $(R=.36)$; groepslidmaatschap (i.c. het op de nominatie staan om de maatwerk-, dan wel de standaardtraining te volgen) hangt op dat tijdstip niet samen met de 'gedragsintentie'. Bij de tweede meting zien we daarentegen een stijging (van $R=.66$ naar .76 wanneer groepslidmaatschap wordt toegevoegd). Deze resultaten laten zien dat de groepen in het begin (eerste meting) niet van elkaar verschilden, terwijl de regressiecoëfficiënten voor zowel de variabelen uit het 'Reasoned Action Model' als voor de deelname aan een maatwerkprogramma pas na de interventie stijgen. De deelname aan het maatwerkprogramma zou hierbij voor een deel het verschil tussen de groepen kunnen verklaren, waardoor kan worden aangenomen dat een maatwerkprogramma gebaseerd op de principes van de 'Reasoned Action Approach' en 'Intervention Mapping' een beter resultaat voorspelt dan een standaardprogramma. De gevonden resultaten op de afzonderlijke onderzoeksvariabelen 'attitude', 'ervaren controle' en 'ervaren norm' zijn daarentegen erg zwak een deels teleurstellend. Zo blijkt slechts de variabele 'attitude' in de tweede meting invloed te hebben op het daadwerkelijke gedragsvoornemen $(\beta=.40 ; t=$ $2.98 ; p<.01)$ en kan men aannemen dat, naast de deelname aan het maatwerkprogramma, de 'attitude' na de eerste interventie de beste voorspelling geeft voor het gedragsvoornemen. Bij alle andere metingen bleken de variabelen geen verklaring te geven van het gedragsvoornemen $(\beta<.40 ; t<2.0 ; p>.05)$.

\subsection{Conclusie}

In dit deelonderzoek stond de ontwikkeling van een geschikt meetinstrumentarium ter beantwoording van de hypothesen van dit proefschrift centraal. Daarnaast is onderzocht of en - zo ja - in welke mate een op 'Intervention Mapping' ontwikkelde maatwerkcommunicatietraining gebaseerd op de 'Reasoned Action Approach' in combinatie met de principes van 'Intervention Mapping' een sterker en langduriger effect op het beoogde gedrag zou hebben dan een standaard communicatietraining. De resultaten laten ten eerste zien dat de 'Reasoned Action Approach' een bruikbare theoretische invalshoek is bij het ontwerp van een op gedragsverandering gerichte training. De gehanteerde variabelen van het 'Reasoned Action Model' bieden een goed richtsnoer voor het opstellen van een evaluatie-instrument. Ondanks de soms teleurstellende uitkomsten van de statistische analyses lijkt de gehanteerde vragenlijst redelijk betrouwbaar te zijn en heeft in mindere mate een voorspellende waarde.

De in het onderzoek gebruikte vragenlijst lijkt een mogelijkheid te bieden om het effect van een training te kunnen evalueren. Ten tweede bleek dat door 'Intervention Map- 
ping' (IM) als praktische aanpak voor gedragsverandering de opbrengst van een op gedrag gerichte training duidelijk verbeterde. De door Schaalma et al. (2001) beschreven onderzoeksopzet en de aanbevolen stappen bieden een goede richtlijn om heldere doelen te stellen en het effect van gedragsverandering op langere termijn op niveau te houden. Daarbij zijn effecten op alle variabelen voor de experimentele groep aangetroffen, in tegenstelling tot de controlegroep, waarbij statistisch geen significante veranderingen werden waargenomen. De follow-upmeting na circa drie maanden toont aan, dat de experimentele groep ook na de training de aangetroffen verschillen ten opzichte van de controlegroep blijft behouden. Door de kleine steekproefomvang $(N=39)$ konden niet alle gewenste statistische methoden worden toegepast. Zo was een (multi)factoranalyse zeer bruikbaar geweest bij de constructie van de uiteindelijke schaal. Deels zijn deze belemmeringen opgelost door de validatie en betrouwbaarheidsanalyse van de vragenlijst. Tevens suggereerden de uitkomsten dat er sprake is van voldoende statistische power: de significante verschillen tussen de onderzoeksgroepen en de ontwikkelingen in de tijd maken het onaannemelijk dat gebrek aan statistische power de resultaten sterk vertekend heeft. Door de gekozen aanpak zou men kunnen aannemen, dat de deelnemers aan het maatwerkprogramma meer aandacht of feedback hebben ontvangen dan de deelnemers in de standaardgroep en dat daardoor het effect in grote mate zou kunnen zijn beïnvloed. In de praktijk kregen alle deelnemers feedback op hun gedrag. In de standaardaanpak was deze tijdens oefeningen voorzien en in gesprekken met de mededeelnemers. Het verschil met het maatwerkprogramma lag met name in het expliciet koppelen van het 'Reasoned Action Model' aan de leerdoelen van de deelnemers en de uitkomsten van de vragenlijst (i.e. het type feedback verschilde, maar de hoeveelheid niet). Aan de deelnemers van beide programma's is gemiddeld een uur extra uitleg en toelichting per deelnemer gegeven. Aan het begin van de training is bij het maatwerkprogramma aandacht geschonken aan de theorie van de 'Reasoned Action Approach' en het daarin gehanteerde 'Reasoned Action Model'. Het is dus niet aannemelijk, dat de verschillen tussen beide groepen deelnemers veroorzaakt is door grote verschillen in de mate van aandacht die zij ontvingen. Ondanks de zwakke statistische uitkomsten kan gegeven de omstandigheden voorzichtig worden geconcludeerd, dat het ontwikkelde instrumentarium en de ontwikkelde methode voldoende betrouwbaarheid en validiteit bieden voor verder onderzoek en toepassing in de praktijk. 


\section{Drie casestudies in de praktijk}

\subsection{Inleiding}

In het vorige hoofdstuk is de ontwikkeling van het meetinstrument op basis van de 'Reasoned Action Approach' van Fishbein en Ajzen (2010) beschreven. In een gecontroleerde setting hebben twee trainingsgroepen een training 'Effectieve Communicatie' doorlopen, waarbij de deelnemers vooraf, tijdens en na de training terugkoppeling is gegeven over de uitkomst van de vragenlijst. Ook is een relatie gelegd met hun individuele leerbehoefte en het gewenste gedrag. Met behulp van de processtappen van 'Intervention Mapping' zijn bij de experimentele groep knelpunten geïdentificeerd en oplossingsrichting voor de deelnemers zo aangepast, dat er een relatie was tussen probleemanalyse en de geboden oplossing. Voor de vier controlegroepen heeft deze aanpassing niet plaatsgevonden; zij hebben een standaardprogramma doorlopen. Voor beide groepen waren de trainingsinhoud en -onderdelen identiek. De uitkomsten suggereren een positief beeld in relatie tot de gekozen maatwerkaanpak. Het ontwikkelde meetinstrument en de procesaanpak bleken een matig positieve invloed op de uitkomst van de training te hebben en ook op langere termijn na de training een beter effect in vergelijking met de controlegroepen te bieden. Met de ontwikkelde vragenlijst konden knelpunten (barrières) vooraf worden geïdentificeerd en daarmee ook het mogelijke effect van een gekozen interventie.

Daarnaast bleek 'Intervention Mapping' een procesaanpak die deelnemers inzicht geeft in het eigen gedrag en mogelijke oplossingsrichtingen. Door gericht een aantal processtappen te doorlopen, worden deelnemer, trainer en organisatie gedwongen het veranderdoel duidelijk in te kaderen en op zoek te gaan naar bij het probleem passende oplossingsrichtingen. Het dwingt trainer en deelnemer het probleem te specificeren en de gekozen interventie te evalueren. Met deze uitkomsten worden de deelvragen $1 \mathrm{t} / \mathrm{m}$ 4 van dit onderzoek redelijk beantwoord. Door de op basis van de 'Reasoned Action Approach' ontwikkelde vragenlijst lijkt de effectiviteit van een (gedrags)interventie te kunnen worden meten (deelvraag 1) en bovendien worden ook de bij de interventie belemmerende en bevorderende factoren in kaart gebracht (deelvraag 2). Door toepassing van de principes van het 'Intervention Mapping' model wordt het (interventie)proces geoptimaliseerd (deelvraag 3 ) en lijkt de terugkoppeling aan de deelnemers over de voor het resultaat belemmerende en bevorderende factoren een positieve invloed op de beoogde interventie te hebben (deelvraag 4).

Onbeantwoord blijft de vraag hoe verschillende interventies op het gebied van gedragsverandering in diverse settingen goed met elkaar kunnen worden vergeleken. Tevens rijst de vraag of dergelijke resultaten ook bij andere gedragsinterventies en in minder gecontroleerde omstandigheden kunnen worden gevonden. Bij een positieve uitkomst zouden het ontwikkelde meetinstrument en de ontwikkelde methode een goede basis vormen om het effect van gedragsinterventies te meten en de effectiviteit daarvan te verbeteren. Derhalve is tot een aantal vervolgonderzoeken besloten. Ook hierbij was vanuit onderzoekstechnisch oogpunt sprake van niet-gecontroleerde trainingssituaties. Het betreft kleine groepen deelnemers, in een specifieke trainingssituatie, waarbij geen gebruik kan worden van een controlegroep. Daarom is getracht steeds dezelfde procesaanpak toe te passen. Daarbij was het raamwerk (de vragenlijst gebaseerd op het 'Reasoned Action Model' uit de 'Reasoned Action Approach' van Fishbein 
en Ajzen, 2010 en de principes van het 'Intervention Mapping'-model) leidend, terwijl de probleemstelling en de gekozen interventies wel van elkaar konden verschillen.

Bij de uitvoering van deze casestudies zijn reeds vooraf een aantal beperkingen geïdentificeerd, die een ongunstige invloed hebben op de kwaliteit van het onderzoek. Een zeer belangrijk vraagstuk betreft de criterium-validiteit. Omdat het veranderdoel bij dergelijke praktische vraagstukken in de regel met verzamelbegrippen (zoals 'effectief samenwerken', 'projectmatig werken', 'effectief communiceren' etc.) wordt omschreven, dienen de gedragscriteria eenduidig aangescherpt te worden. In het voorafgaande hoofdstuk over de ontwikkeling van het meetinstrument is reeds gebleken, dat het uitwerken van alle gedragscriteria de vragenlijst in omvang laat toenemen en bij kleine groepen het gevaar bestaat van vragen en/of doelstellingen die slechts een klein deel van de onderzoeksgroep betreffen. Daartegenover staat, dat de opdrachtgever (en deelnemers) de tijd zo goed mogelijk willen benutten en geen belang hechten aan een uitgebreide vragenlijst en naar criteria moet worden gezocht die de gehele groep betreffen. Dit probleem is bij alle deelonderzoeken vooraf met een stuurgroep besproken, waarbij de kerndoelstellingen zijn geïdentificeerd en vervolgens met iedere deelnemer in een interview is besproken. Daarmee is de kans toegenomen, dat alle deelnemers een eenduidig beeld hebben bij de interpretatie van het beoogde veranderdoel (gedrag). Tevens is bij de eerste bijeenkomst nogmaals gezamenlijk hierop ingegaan. Strikt genomen is hierbij slechts sprake van expertvaliditeit en het creëren van een gemeenschappelijk beeld bij de deelnemers. Uit de interviews bleek dat de deelnemers zeer goed in staat waren concreet en uniform gedrag te kunnen benoemen in relatie tot de in de vragenlijst opgestelde verzamelbegrippen. De verdere uitwerking van de ontwikkelde vragenlijst in relatie tot de aspecten van het 'Reasoned Action Model' (Fishbein \& Ajzen 2010) was minder problematisch, temeer omdat de barrières en randvoorwaarden door de deelnemers zelf in de interviews zijn aangedragen. Hierdoor is wel in delen afgeweken van het oorspronkelijk opstelde meetinstrument en zijn een deel van de vragen op de specifieke situatie toegeschreven. Wel is getracht deze bij alle onderzoeken gelijk te houden. Een ander probleem was, dat het bij deze deelonderzoeken niet mogelijk was de gedragscriteria en daarmee samenhangende belemmerende en bevorderende aspecten eenduidig te omschrijven, zoals dat bijvoorbeeld bij groepen betreffend gezondheidgerelateerd gedrag wel mogelijk is. Het betreft immers complexere vraagstukken (zoals projectmatig werken) en niet direct aan elkaar gerelateerde factoren (zoals roken en gezondheidgerelateerd gedrag).

Een ander probleem betreft de statistische verwerking in relatie tot de kleine steekproefomvang en het ontbreken van een controlegroep. Vooraf is overwogen om meer meetmomenten in het traject in te plannen zoals bijvoorbeeld Borckardt et al. (2008) suggereren bij onderzoeken van individuele patiëntencontacten. Echter, deze methode is niet helemaal geschikt voor interventies die zich beperken tot enkele dagen achterelkaar en waarin de opdrachtgever de meetmomenten zo beperkt mogelijk wilde houden. Ook een vergelijking van de effecten tussen interventiegroep met de waarden van de doelgroep , zoals Chakhssi, Ruiter en Bernstein (2010) doen, was niet mogelijk, omdat de gehele doelgroep onderdeel is van de interventie. Met één opdrachtgever is wel de mogelijkheid van een examen (praktijktest) of beoordeling besproken, zoals het bijvoorbeeld in een 'skills lab'-achtige omgeving bij geneeskundestudenten wordt toegepast (Scherpbier et al. 2000). Deze optie is uit kostenoverwegingen en de snel wisselende samenstelling verworpen; begrijpelijk omdat, in tegenstelling tot bijvoorbeeld universitaire opleidingen, de interventie meer gericht is op de korte termijn en het 
examen per groep of zelfs per deelnemer zou moeten worden uitgewerkt. Er is wel de suggestie geopperd een soort 'beoordeling' in het functioneringsgesprek op te nemen. Hierbij zou vooraf aan een training het specificeren van het leerdoel moeten plaatsvinden, waarop later in de praktijk kan worden getoetst. Obdeijn en Lubberts (2013) bieden hiervoor een praktische handreiking, waarbij er nadrukkelijk naar wordt gekeken, hoe veranderdoelen in het personeelsbeleid kunnen worden geïntegreerd. Bij de meeste deelnemers bleek geen tijd voor een dergelijke aanpak en ontbrak het bij de personeelsdienst aan capaciteit voor een organisatiebrede toepassing.

Een ander praktisch probleem bij gedragsinterventies in organisaties is het ontbreken van een controlegroep. Voor trainingen in de praktijk zou dat betekenen dat de interventiegroep wordt gehalveerd en dat een deel van de deelnemers in beginsel bij de te volgen training wordt uitgesloten. Door praktische bezwaren en vooral grote weerstand bij de opdrachtgever is naar een methode gezocht, die de mogelijkheid biedt ook zonder gebruik te maken van een controlegroep. Een zeer hanteerbare oplossing voor het hierboven aangeduide probleem bleek uiteindelijk de zogenoemde 'Internal Referencing Strategy' (IRS, Garson, 2008; Haccoun \& Hamtieux, 1994) ook wel bekend als het 'Non Equivalent Dependent Variable Design' (Cook \& Campbell, 1979). Met de IRS worden de effecten van interventie vergeleken met de effecten op een variabele die juist niet zou moeten worden beïnvloed en wel is meegenomen in de vragenlijst. De veronderstelling daarbij is, dat de deelnemers een effect zullen laten zien op de gedragsaspecten die door de training beïnvloed zouden moeten worden, in vergelijking tot de gedragscriteria die geen relatie hebben met de gekozen interventie (idealiter veranderen de uitkomsten op dat laatste niet). In dat geval kan er aangenomen worden, dat een interventie effect had, zonder dat er een controlegroep wordt ingezet. Daarbij is wel van belang dat de gekozen controle-gedragscriteria niet te nauw aansluiten bij het veranderdoel, maar ook weer niet zo ver van de doelstelling afwijken, dat deze 'controlevragen' voor de deelnemer onmiddellijk duidelijk worden (zie verder hoofdstuk 5).

De hier beschreven bezwaren zijn een goede illustratie (en mogelijke verklaring) van het gegeven dat onderzoeken naar de effectiviteit van gedragsinterventies in organisaties zo moeilijk en daardoor schaars zijn. In dit proefschrift is dan ook bewust een afweging gemaakt tussen praktische haalbaarheid en het beste onderzoeksdesign vanuit statistische oogpunt ten gunste van de praktische toepassing. 


\subsection{Casestudie 1: Het productiebedrijf in Nederland $(N=170)$}

\subsubsection{De context}

Het onderzoek heeft plaatsgevonden bij een afdeling voor technisch onderhoud binnen een productie-eenheid van een multinational. Het betreft een $24 / 7$ - bedrijf, waarbij halfproducten in diverse bewerkingen tot een eindproduct worden verwerkt. Het productieproces is opgedeeld in een aantal bewerkingsfasen. Binnen iedere bewerkingsfase zijn de teams zelf verantwoordelijk voor de kwaliteit van hun product. De productie is in grote mate afhankelijk van de technische toestand van de diverse machines. Hierbij komt nagenoeg alleen technische kennis van pas. leder team in het productieproces wordt voor klein onderhoud en spoedklussen ondersteund door eigen technisch onderhoudspersoneel. Voor groot onderhoud, technisch beheer en onderhoudsmanagement (inclusief contracten met onderaannemers) is de onderhoudsafdeling zelf verantwoordelijk. In het algemeen kent technisch onderhoud vier 'klassieke' vormen:

- Vorm 1: Het alleen uitvoeren van reparaties en wat smeerwerkzaamheden (brandweerconcept).

- Vorm 2: Het doelmatig uitvoeren van onderhoud door preventieve onderhoudssystemen en periodieke revisies (onderhoudsmanagement).

- Vorm 3: Het in kaart brengen van storingen en het opstellen van optimale onderhoudsconcepten (installatiebeheer).

- Vorm 4: Integraal technisch onderhoud waarbij al bij het ontwerp van installaties rekening wordt gehouden met bedrijfszekerheid en onderhoudbaarheid (technisch management).

Bij de betreffende onderhoudsafdeling zijn met name vormen 1 en 2 aanwezig. Verder kent de afdeling grofweg drie vakdisciplines: regeltechniek (E\&I), hydrauliek, mechaniek en 'all-round'. Tussen deze disciplines bestaan grote verschillen in werkwijze. Regeltechniek functioneert ten opzichte van het productieproces sterk op de achtergrond, terwijl de andere direct op de werkvloer opereren (dat geld vooral voor de 'all-round'medewerkers). De huidige werkwijze is van oudsher vooral reactief georganiseerd. Als zich problemen of storingen binnen een productieonderdeel voordoen, dan worden deze op afroep verholpen. Deze manier van werken wordt versterkt door de wijze van prestatiebeloning. In de huidige situatie krijgt ieder productieteam een extra bonus bij het behalen van de streefcijfers. Een productiestop door gepland onderhoud zou een financiële strop voor het betreffende team betekenen.

\subsubsection{De opdracht}

In de toekomst wil de organisatie zich meer richten op installatiebeheer (vorm 3) en daarbij ook één heldere strategie bepalen met betrekking tot resterende activiteiten op het brandweer- en onderhoudsmanagement. Om dit te realiseren, heeft de afdeling onder andere een veranderingstraject ingezet om van een productiegestuurde (reactieve) naar een klantgerichte (proactieve) organisatie te komen. Dit voornemen heeft onder een deel van het personeel tot onrust geleid omdat het, naast mogelijk ontslag (in het nieuwe concept zijn minder onderhoudsmonteurs nodig), ook onduidelijk was hoe het einddoel concreet vorm zou worden gegeven. 
Als antwoord daarop is een cultuurgroep opgezet, die de verandering dient te ondersteunen. Hiervoor is een project gestart met een tweeledige doelstelling. Op de eerste plaats wil men de randvoorwaarden scheppen om het boogde productieplan te realiseren. Daarnaast wil men een professionalisering van de organisatie bewerkstelligen.

Nadat het project gestart was, kwamen de eerste berichten van de werkvloer, met als teneur 'leuk al die verbeterprojecten, maar zo houden we geen tijd over voor onze dagelijkse werkzaamheden'. Daar waar het om houding en gedrag ging, bleek een groot deel van de medewerkers deze veranderingen onvoldoende te accepteren. Medewerkers vonden het moeilijk om de gewenste cultuurverandering op te volgen en er ging veel energie zitten in het elkaar overtuigen. Om het veranderpotentieel in kaart te brengen en de beoogde veranderdoelstelling te kunnen monitoren, is door de leiding van de afdeling besloten externe hulp in te winnen.

\subsubsection{De aanpak}

Het ontwerp van het onderzoek is opgesteld in samenspraak met de verantwoordelijke manager, de verantwoordelijke P\&O-functionaris en werkgroepleden van het projectteam. De veranderdoelstelling was, dat door verbetering van het contractmanagement, het werken met prestatie-indicatoren en een verbetering van de inkoopstrategie kosten konden worden teruggedrongen. Daarnaast zou ook aan de stroomlijning van het werkproces en aan houding en gedrag van medewerkers gewerkt worden. De opdrachtgever vond het vooral wenselijk om medewerkers inzicht in de stand van zaken te verschaffen en om de doelstellingen betreffend houding en gedrag te concretiseren. Hierdoor zou het effect van gedragsverandering permanent onder de aandacht van de betrokken personen kunnen worden gebracht.

Aan het onderzoek hebben alle medewerkers van de onderhoudsafdeling ( $N=170)$ en een aantal lijnchefs $(N=7)$ uit de productie deelgenomen. Conform de principes van 'Intervention Mapping' kent het onderzoek een aantal stappen die gedurende één jaar zijn uitgevoerd. Eerst werd in een steekproef van de betrokken medewerkers het te onderzoeken gedrag zo gedefinieerd, dat het meetbaar was en in een vragenlijst kon worden opgenomen. Vervolgens zijn deze gedragscriteria opnieuw in individuele interviews besproken ( $N=20$ participanten, aselect getrokken uit alle functiegroepen), waarbij de drie onderzoeksvariabelen uit het 'Reasoned Action Model' (zie hoofdstuk 4) specifiek voor deze doelgroep aangescherpt werden. De uitkomsten van de interviews zijn vertaald naar een vragenlijst met 63 items, die aansluit bij de 'Reasoned Action Approach' van Fishbein en Ajzen (2010). Deze gebruikte vragenlijst is gebaseerd op de uitkomsten van hoofdstuk 3 (Rauner et al., 2005), aangepast aan de specifieke situatie van het productiebedrijf. Daarbij zijn vooral de uitkomstcriteria voor gewenst gedrag aangepast aan de specifieke situatie en bleven de reeds gevalideerde vragen betreffende de in het 'Reasoned Action Model' geïllustreerde criteria nagenoeg ongewijzigd.

De respondenten konden het in meer of mindere mate eens zijn met de 63 in de vragenlijst gepresenteerde stellingen. In samenspraak met de projectgroep werd voor een 6-puntsschaal gekozen. Door het gebruik van een 6-puntsschaal worden deelnemers 'gedwongen' een keuze te maken tussen positief en negatief in plaats van neutraal. Daarnaast leidt het gebruik van een 6-puntsschaal tot een specifieker resultaat (positief of negatief) aan de hand waarvan gerichte stappen ondernomen kunnen worden ter verbetering van de training. De uitkomst geeft dus niet alleen aan of iets wel dan wel niet aanwezig is, maar ook nog hoe sterk (veel. Hierdoor wordt, behalve een positief of negatief oordeel, ook aangegeven hoe sterk dit oordeel wordt ervaren. Een ander 
voordeel was, dat mogelijke interventiestrategieën duidelijker gericht konden worden op de aandachtsgebieden die het meest extreem scoren. Een nadeel is, dat respondenten geen 'neutraal' of 'weet het niet'- antwoord kunnen geven als bijvoorbeeld de vraag niet van toepassing is.

De conceptvragenlijst is vervolgens aan negen experts (leden van het projectteam) voorgelegd en op inhoudsvaliditeit onderzocht. De uiteindelijke vragenlijst bevatte 44 items (inclusief demografische gegevens en open vragen). Ter onderbouwing van de constructie van het meetinstrument is per schaal de Cronbach's $\alpha$ berekend. Deze varieerde van .67 tot .84 (zie tabel 4.4), wat op een redelijke betrouwbaarheid duidt. Gedurende een periode van vier weken is de definitieve vragenlijst onder alle 170 medewerkers van de onderhoudsafdeling afgenomen (respons van 53,5\%). Aan de hand van een kwalitatieve analyse van de gemiddelden en een spreiding van de in het 'Reasoned Action Model' beschreven factoren zijn de uitkomsten van deze voormeting met de verantwoordelijke manager en de projectgroep besproken. Hiervoor zijn de uitkomsten van deze eerste meting zijn op volgorde gerangschikt en vervolgens zijn de gemiddelden, de standaarddeviatie $(S D)$, de variantie, het minimum en het maximum berekend. $\mathrm{Bij}$ een standaarddeviatie groter dan 1 is aangenomen, dat de meningen erg verdeeld zijn. Er zijn in dat geval groepen of personen die extremer positief of negatief over het betreffende onderwerp denken. Alle items die meer dan één punt van het gemiddelde afweken en waarbij de standaarddeviatie kleiner dan 1 is, zijn in het algemeen als positief beoordeeld. Alle items groter dan één punt van het gemiddelde en een standaarddeviatie kleiner dan 1, werden als negatief beoordeeld. Aan de hand van deze criteria zijn alle items in de drie subcategorieën 'positief', 'neutraal' en 'negatief ten opzichte van het project' onderverdeeld (zie tabel 4.1). De uitkomsten laten zich als volgt samenvatten:

\section{Tabel 4.1: Beoordelingscriteria}

\begin{tabular}{lll}
\hline Positief (gem.<2.5 en SD<1) & Neutraal (gem.=3 en SD<1) & Negatief (gem. $>\mathbf{3 . 5}$ en SD<1) \\
- Verantwoordelijkheid nemen & - Het werkmateriaal & - Inhoud van het project \\
- Kostenbewustzijn & - Positieve leiding & - Bijdrage van het project \\
- Plezier in het werk & - Waardering geven / ontvangen & - Voordelen van het project \\
- Open staan voor veranderin- & - Duidelijkheid & - Nut om te veranderen \\
gen & - Coördinatie werkzaamheden & - Terugkoppeling van het pro- \\
- Initiatief nemen & - Duidelijke communicatie & ject \\
- Zich houden aan afspraken & - Afspraken nakomen & - Waardering als je iets doet \\
- Elkaar waardering geven & - Doen wat je zegt & voor het project \\
& - Terugkoppeling & - Houding collega's t.a.v. het \\
& - Tevredenheid over de leiding & project \\
\hline
\end{tabular}

De onder 'positief' aangetroffen items hadden met name betrekking op de gewenste resultaten. Dat wil zeggen: de deelnemers denken/zijn ervan overtuigd, dat zij het op dit moment goed doen en de gewenste gedragingen al vertonen. Men geeft aan, dat men de overtuiging heeft dat collega's zich verantwoordelijk voelen voor het werk, er kostenbewustzijn is, personen met plezier naar hun werk gaan, men open staat voor de mening van anderen, mensen initiatief nemen om dingen op te pakken, anderen open staan voor de mening over henzelf, men zich houdt aan gemaakte afspraken en collega's initiatief nemen om dingen op te pakken. 
Als 'neutraal' zijn vooral de randvoorwaarden beoordeeld en enkele beoogde resultaten. Zo is men van mening dat men over voldoende gereedschap beschikt en dat men weet welke bijdrage men zelf aan project kan leveren. Verder heerst er enige twijfel over of er goede coördinatie is, of anderen zich houden aan gemaakte afspraken, of men zegt wat men doet en doet wat men zegt, of er voldoende terugkoppeling is en men is van mening dat er toch een 'Zwarte Pieten spel' bedreven wordt.

De items die in de categorie 'negatief' vallen, hebben met name betrekking op de 'attitude' en de ervaren steun door anderen. Zo is niet geheel duidelijk, wat het veranderproject voor de betreffende persoon inhoudt, denkt men geen voordelen uit het project te kunnen halen en is men van mening, dat het geen nut heeft om het gedrag in de toekomst eventueel bij te stellen. Verder is men van mening, dat men te weinig steun krijgt door de direct leidinggevende en door anderen. Ook heeft men de overtuiging, dat collega's weinig positief tegenover het project staan, heeft men weinig waardering ervaren en heerst er enige twijfel over de aansturing door de chef.

Opmerkelijk was dat de respondenten met betrekking tot het gewenste gedrag ('intentie') van mening waren, dat men het redelijk goed deed en het nog helemaal niet zo slecht ging op het werk. Met betrekking tot de randvoorwaarden ('ervaren controle') en de sociale steun ('ervaren norm' ) heerste enige verscheidenheid van mening (een hoge standaarddeviatie). Sommige vonden dat het goed ging, anderen juist weer niet. Het meest slecht gesteld was het met de 'attitude'. De respondenten vonden dat het veranderproject henzelf geen voordelen bood, vroegen zich af wat het nut ervan was en konden moeilijk een verband tussen hun eigen werkzaamheden en het project leggen. Items met een relatief hoge score (positief) betreffen met name het beoogde gedrag van het project. Dat wil zeggen de deelnemers denken/zijn ervan overtuigd, dat zij het op dit moment goed doen en de gewenste gedragingen al vertonen. De laag scorende items (negatief) hebben met name betrekking op de 'attitude' en de 'ervaren norm' door anderen. Zo is niet duidelijk wat het project voor de betreffende persoon inhoudt, denkt men geen voordelen door het project te kunnen behalen en vindt het niet van nut om het gedrag in de toekomst eventueel bij te stellen. Grote diversiteit (grote standaarddeviatie) betreft met name de randvoorwaarden en de 'gedragsintentie'.

Voor mogelijke gedragsverandering in de toekomst zijn deze bevindingen een slechte uitgangpositie. Een persoon die van mening is, dat de huidige situatie geen problemen oplevert en vindt dat gedragsverandering geen toegevoegde waarde heeft, zal weinig gemotiveerd zijn om in de toekomst ander gedrag te vertonen. Ook bestaat het gevaar dat de initiatiefnemers van een verandertraject de situatie (i.e. het gedrag) negatiever inschatten, dan dat in de praktijk het geval is en daardoor aan geloofwaardigheid inboeten. In dit geval waren de betrokken medewerkers van mening, dat het beoogde project weinig voordelen voor hun directe werkzaamheden biedt. Verder waren er twijfels over het nut ervan en kon men moeilijk een verband tussen de eigen werkzaamheden en het project leggen. De uitkomsten van dit vooronderzoek maken duidelijk dat er weinig verandernoodzaak en urgentiebesef onder de werknemers aanwezig was.

Op basis van dit vooronderzoek zijn door de projectgroep aandachtpunten voor mogelijke interventiestrategieën ontwikkeld en aan het management voorgelegd. Hiervoor zijn ervaringen van andere verandertrajecten in de organisatie onderzocht, is literatuur geraadpleegd en zijn veranderstrategieën geformuleerd. 
Met deze conclusies zijn in een brainstorm met de werkgroep een aantal concrete activiteiten geformuleerd om het project een positieve impuls te geven en de kans op gedragsverandering te verhogen. Deze zijn vooral gericht op het verhogen van het urgentiebesef en de verandernoodzaak door bijvoorbeeld:

- benchmarks of normen te stellen en deze opnemen bij de beoordelingen

- doelbewust niet te snel te interveniëren en/of medewerkers met het negatieve gedrag te confronteren, om het gevoel van de verandernoodzaak te vergroten;

- 'key performance indicatoren' (KPI's) op te stellen om het gevoel voor de eigen bijdrage te vergroten;

- 'schok' teweeg te brengen door voorbeelden te stellen (van slecht gedrag) en goede gedrag te belonen;

- teams op te heffen waarin de samenwerking als erg negatief wordt ervaren;

- een duidelijkere scheiding te maken tussen productie en onderhoud (semi - privatisering);

- anderen uit te nodigen (bijvoorbeeld onderhoudsdiensten die deze veranderingen al achter de rug hebben);

- de mensen zelf te laten bepalen wat normen zijn en daarop (streng) toe te zien;

- de leiding meer op de werkvloer te laten zijn, positief gedrag te bekrachtigen en negatief gedrag bespreekbaar te maken.

Met het management en de betrokken personeelsfunctionaris werd afgesproken dat deze voorstellen zouden worden meegenomen in het plan van aanpak. De P\&Oafdeling heeft aan de hand van de adviezen van de werkgroep een opleiding voor medewerkers en leidinggevende aangeboden ('resultaatgericht leidinggeven', 'coachend leidinggeven', 'persoonlijke effectiviteit', 'teambuilding', 'projectmatig werken'). Tevens zijn in de beoordelingscyclus criteria opgenomen in relatie tot dit traject. Vanuit P\&O zij bij alle teams voorlichtingsbijeenkomsten gegeven en is de medewerkers de gelegenheid geboden een individueel opleidingsplan te ontwikkelen. Na een jaar is de onderzoeker opnieuw uitgenodigd om een tweede meting uit te voeren ten einde de voortgang van het project te kunnen monitoren.

\subsubsection{De uitwerking}

Voor de uitwerking van de interventies was de opdrachtgever zelf verantwoordelijk; de onderzoekers hadden daarop geen invloed. Na een periode van een jaar vond opnieuw een meting plaats met een respons van $36,5 \%$ en zijn de uitkomsten daarvan uitvoerig met de werkgroepleden en het management besproken. Gezien de geringe respons bij deze tweede meting ten opzichte van de eerste meting $(53,4 \%)$ zijn de demografische gegevens op verschillen onderzocht (zie tabel 4.2). De uitkomst laat zien, dat er geen significant verschil bestaat tussen de demografische kenmerken van de respondenten van meting 1 en meting 2 . Bij verder onderzoek naar de effecten en de ontwikkelingen binnen de onderhoudsafdelingen kan er daarom van worden uitgegaan dat de steekproef uit de 170 medewerkers voor beide metingen met elkaar vergelijkbaar is. 
Tabel 4.2: Analyse op de algemene gegevens tussen de meting 1 en meting 2

\begin{tabular}{lcccccc}
\hline T-Test & $\boldsymbol{N}$ & Missing & df & $\boldsymbol{t}$ & $\boldsymbol{F}$ & $\boldsymbol{p}$-waarde \\
\hline Leeftijd & 141 & 12 & 139 & $-1,898$ & 1,465 &, 06 \\
\hline Chi-kwadraat toets & $\boldsymbol{N}$ & Missing & $d f$ & Pearson Chi-Kwadraat & Significantie \\
\hline Burgerlijke staat & 137 & 16 & 3 &, 677 &, 879 \\
\hline Opleiding & 136 & 17 & 5 & 5,001 &, 415 \\
\hline Functie & 125 & 28 & 10 & 11,023 &, 356 \\
\hline$(p<.05=$ significant verschil) & & & & & \\
\hline
\end{tabular}

\subsubsection{Uitkomsten}

De analyse van de effecten van de uitgevoerde interventies heeft in eerste instantie plaatsgevonden op het niveau van de somscores op de variabelen in het 'Reasoned Action Model'. Hiervoor is gebruik gemaakt van een multivariate variantieanalyse (MANOVA). Grafiek 4.1 presenteert de betreffende gemiddelden. Hoewel er een lichte daling van de scores op de betreffende concepten valt waar te nemen, is er geen significant verschil tussen de metingen: multivariate $F(4,107)=.67, n s$.

Grafiek 4.1: Weergave voor-en nameting




De uitkomsten van de 2e meting bevestigen het eerder aangetroffen beeld. Statistisch gezien is er weinig tot geen verschil tussen de twee metingen waar te nemen. Ook kan worden geconcludeerd, dat personen over het algemeen 'iets negatiever' de vragen hebben beantwoord (zie tabel 4.3). De werkgroep heeft hieruit geconcludeerd dat de betrokken medewerkers globaal van mening zijn dat:

- het zinvol is het eigen gedrag te veranderen (item 3);

- zij een bijdrage kunnen leveren aan het project (item 4 is positiever bij meeting 2);

- er voldoende terugkoppeling is over het project (item 15);

- zij het gevoel hebben dat er onvoldoende materiaal/gereedschap aanwezig is (item 6);

- men gewaardeerd wordt voor de inzet bij het project (item 9);

- de productie voldoende betrokken is (item 17);

- de leidinggevende niet betrokken is bij het project (item 10);

- collega's zich minder verantwoordelijk voelen voor hun fouten (item 18);

- kostenbewustzijn niet van belang is (item 19);

- zij minder betrokken zijn bij het werk (item 21);

- zZij zich minder verantwoordelijk voelen voor de eigen fouten (item 23);

- men zich minder aan gemaakte afspraken houdt (item 25);

- men weinig initiatief neemt om dingen op te pakken (item 28); en

- collega's minder open staan voor de mening van anderen (item 33).

In tabel 4.3 wordt een overzicht van de gemiddelden en de standaarddeviatie gegeven.

Tabel 4.3: Overzicht conclusies werkgroep:

\begin{tabular}{|c|c|c|c|c|c|}
\hline & & $\begin{array}{c}\text { Gem. } \\
\text { meting } 1\end{array}$ & SD & $\begin{array}{c}\text { Gem. } \\
\text { meeting } 2\end{array}$ & SD \\
\hline 3 & $\begin{array}{l}\text { Het heeft voor mij nut om mijn eigen gedrag in } \\
\text { de toekomst te veranderen }\end{array}$ & 4.38 & 1.46 & 3.97 & 1.25 \\
\hline 4 & $\begin{array}{l}\text { Ik kan een actieve bijdrage leveren aan (Project- } \\
\text { naam) }\end{array}$ & 3.22 & 1.54 & 3.77 & 1.63 \\
\hline 6 & $\begin{array}{l}\text { Ik heb voldoende materiaal/gereedschap om } \\
\text { mijn werk te kunnen doen }\end{array}$ & 2.39 & 1.27 & 2.75 & 1.60 \\
\hline 9 & $\begin{array}{l}\text { Ik wordt door anderen gewaardeerd als ik mij } \\
\text { inzet voor (Projectnaam) }\end{array}$ & 4.10 & 1.30 & 4.19 & 1.41 \\
\hline 10 & $\begin{array}{l}\text { Mijn direct leidinggevende staat positief tegen- } \\
\text { over (Projectnaam) }\end{array}$ & 2.57 & 1.47 & 3.12 & 1.49 \\
\hline 15 & $\begin{array}{l}\text { Er is terugkoppeling over de stand van zake met } \\
\text { betrekking tot (Projectnaam). }\end{array}$ & 4.07 & 1.37 & 4.25 & 1.29 \\
\hline 17 & $\begin{array}{l}\text { Productie is betrokken bij de ontwikkelingen } \\
\text { binnen de onderhoudsafdeling }\end{array}$ & 4.29 & 1.27 & 4.60 & 1.14 \\
\hline 18 & $\begin{array}{l}\text { Mijn collega's voelen zich verantwoordelijk voor } \\
\text { de fouten die zij maken in hun werk }\end{array}$ & 2.23 & 1.06 & 2.42 & 1.32 \\
\hline 19 & $\begin{array}{l}\text { Kostenbewustzijn is belangrijk voor mijn werk- } \\
\text { zaamheden }\end{array}$ & 1.91 & 1.11 & 2.13 & 1.15 \\
\hline 21 & Ik ben betrokken bij het werk & 1.38 & .55 & 1.46 & .70 \\
\hline 23 & $\begin{array}{l}\text { Ik voel mij verantwoordelijk voor de fouten die ik } \\
\text { maak in mijn werk }\end{array}$ & 1.29 & .45 & 1.39 & .53 \\
\hline 25 & Ik hou mij aan gemaakte afspraken & 1.74 & .66 & 1.77 & .69 \\
\hline 28 & $\begin{array}{l}\text { Ik neem eigen initiatief in het werk om de nodige } \\
\text { dingen op te pakken }\end{array}$ & 1.76 & .75 & 1.98 & .89 \\
\hline 33 & $\begin{array}{l}\text { Mijn collega's staan open voor de mening van } \\
\text { anderen }\end{array}$ & 2.46 & .90 & 2.55 & 1.03 \\
\hline
\end{tabular}


Opvallend aan de uitkomsten is, dat de aangetroffen veranderingen met name betrekking hebben op de antwoorden die randvoorwaarden ('ervaren controle') en het gewenste gedrag ('intentie') betreffen. Medewerkers hebben dus het gevoel, dat minder randvoorwaarden aanwezig zijn en ook het beoogde gedrag is afgenomen. Daarnaast zijn de betrokken medewerkers van mening weinig invloed te hebben op hun werk en de beoogde veranderingen.

Naast de hoofdeffecten wilde de opdrachtgever ook een analyse op itemniveau. Daarvoor is gebruik gemaakt van een $t$-test (zie tabel 4.4). De uitkomsten laten zien dat ook op het niveau van de afzonderlijke vragen nauwelijks significante verschillen tussen meting 1 en meting 2 waar te nemen zijn. Slechts voor vijf vragen werd een significant verschil $(p<.05)$ aangetroffen; gezien het aantal vergelijkingen valt niet uit te sluiten, dat deze verschillen te wijten zijn aan kanskapitalisatie. Met het verantwoordelijke management en de betrokken werkgroep zijn de uitkomsten geanalyseerd.

De aangetroffen uitkomsten van dit onderzoek, i.c. het gebrek aan verandering, werden zowel door de werkgroep als door de leidinggevenden herkend. Een van de redenen voor de afwezigheid van effecten van het veranderingstraject werd gezien in het feit, dat de hoogst leidinggevende niet expliciet nieuw gedrag ging belonen, maar tijdens bijeenkomsten en gesprekken nadrukkelijk op de output van de productie hamerde. Door de werkdruk kwamen opleidingstrajecten in de knel en ontstond veel weerstand tegen de verandering. Met andere woorden, het maakte de hoogste leidinggevende niet uit, hoe het werk uiteindelijk werd uitgevoerd, als de productdoelstelling maar werd gehaald. Onder deze druk hadden de operationeel leidinggevenden onvoldoende stimulans ervaren om de veranderaanpak actief onder het personeel uit te dragen en voldoende tijd te steken in het bedenken en evalueren van de veranderstrategie. Ook in de productie was veel weerstand tegen de geplande verandering. Een productieteam wordt immers beloond aan de hand van de dagproductie. Een ingepland onderhoud betekent dus uitval voor het productieteam dat op dat moment in de productie werkzaam is, en de leden van dit producteam ontvangen daardoor ook minder loon.

De oorspronkelijk gekozen strategie had weliswaar een goede output tot gevolg, maar het gedrag en de houding veranderden niet. Pas in een later stadium was besloten om ook op competenties en op de gedragsstijl van de leidinggevenden te gaan sturen. De betreffende interventies werden kort voor de tweede meting ingezet: een deel van de operationeel leidinggevenden werd vervangen en positief gedrag werd door het management openlijk beloond. Ook is veel meer gestuurd op de eigen verantwoordelijkheid van iedere medewerker. Omdat dit traject nog niet was voltooid, was de verantwoordelijke manager niet overtuigd van het nut van de tweede meting en wilde derhalve de nameting uitstellen. In feite fungeerde deze tweede meting als een tussentijdse meting van de stand van zaken, die liet zien dat de weinige tot dan toe doorgevoerde interventies nog geen positief effect hadden bewerkstelligd. Het voordeel van deze tweede meting was, dat er inzichtelijk is gemaakt welke barrières er bestonden ten opzichte van de gewenste gedragsverandering. De gestructureerde aanpak van 'Intervention Mapping' dwong de organisatie het probleem duidelijker in te kaderen, bewuste interventiestrategieën te kiezen en het effect daarvan te monitoren. Het nadeel van de gekozen aanpak is dat de onderzoekers weinig tot geen inzicht hadden in de gekozen interventie(s) en de ontwikkelde gedragscriteria nog steeds weinig specifiek bleken te zijn. Van een volledig volgens de principes van IM ontwikkeld verandertraject kon dan ook geen sprake zijn. 
Daarom laat het hier beschreven project slecht gedeeltelijk zien, dat IM in combinatie met een theoriegestuurde aanpak zoals de 'Reasoned Action Approach' nuttig kan zijn. Volgens de betreffende organisatie had het onderzoek wel toegevoegde waarde gehad, omdat de aandacht was gericht op continue procesverbetering van (gedrags)interventies en de ontwikkelde vragenlijst als een soort 'thermometer' de mogelijke veranderingen in de gaten hield. Dit is echter slechts gedeeltelijk waar, omdat men dan ervan uit moet gaan, dat het ontwikkelde instrumentarium voldoende betrouwbaar en valide is. De aangetroffen uitkomsten hebben dan ook vooral betrekking op deelvraag 3 (Hoe kunnen gedragstrainingen worden geoptimaliseerd?).

Tabel 4.4: Overzicht van de vragenlijst

\begin{tabular}{|c|c|c|c|c|}
\hline & & $\begin{array}{l}\text { Cronbach's } \alpha \\
(N=91)\end{array}$ & $\begin{array}{c}t \text {-test } \\
\text { meting 1-2 } \\
\text { (p-waarde) }\end{array}$ & $\begin{array}{c}\text { Gemiddelde } \\
\text { (Range }=1-6 \text { ) } \\
\text { Meting 1/2 }\end{array}$ \\
\hline & ATTITUDE & $\alpha=0.67$ & .48 & 3.24 / 3.11 \\
\hline 1 & Voor mij is duidelijk wat (Projectnaam) inhoudt & .52 & .12 & $S D$ \\
\hline 2 & (Projectnaam) heeft voordelen voor mijn werk & .41 & .23 & $1.14 / 1.14$ \\
\hline \multirow[t]{2}{*}{3} & $\begin{array}{l}\text { Het heeft voor mij nut om mijn eigen gedrag in de } \\
\text { toekomst te veranderen }\end{array}$ & .64 & .07 & \\
\hline & ERVAREN CONTROLE & $\alpha=0.67$ & .11 & $4.10 / 3.79$ \\
\hline 4 & $\begin{array}{l}\text { Ik kan een actieve bijdrage leveren aan (Project- } \\
\text { naam) }\end{array}$ & .42 & $.04 *$ & $S D$ \\
\hline 5 & $\begin{array}{l}\text { Ik heb voldoende kennis om aan (Projectnaam) een } \\
\text { bijdrage te kunnen leveren }\end{array}$ & .48 & .96 & $1.15 / 1.31$ \\
\hline \multirow[t]{2}{*}{6} & $\begin{array}{l}\text { Ik heb voldoende materiaal/gereedschap om mijn } \\
\text { werk te kunnen doen }\end{array}$ & .60 & .12 & \\
\hline & ERVAREN NORM & $\alpha=0.78$ & .20 & $3.75 / 3.54$ \\
\hline 7 & $\begin{array}{l}\text { Mijn leidinggevende stimuleert mij in het kader van } \\
\text { (Projectnaam) }\end{array}$ & .75 & .65 & $S D$ \\
\hline 8 & $\begin{array}{l}\text { Ik ben tevreden over de aansturing door mijn direct } \\
\text { leidinggevende }\end{array}$ & .76 & .63 & $0.92 / 0.86$ \\
\hline 9 & $\begin{array}{l}\text { Ik wordt door anderen gewaardeerd als ik mij inzet } \\
\text { voor (Projectnaam) }\end{array}$ & .73 & .69 & \\
\hline 10 & $\begin{array}{l}\text { Mijn direct leidinggevende staat positief tegenover } \\
\text { (Projectnaam) }\end{array}$ & .73 & $.03 *$ & \\
\hline 11 & Ik ontvang waardering voor mijn werk & .76 & .96 & \\
\hline 12 & $\begin{array}{l}\text { Mijn directe collega staat positief tegenover (Pro- } \\
\text { jectnaam) }\end{array}$ & .72 & $.005^{* *}$ & \\
\hline 13 & $\begin{array}{l}\text { Ik waardeer mijn collega's als zij zich inzetten voor } \\
\text { (Projectnaam) }\end{array}$ & .73 & .31 & \\
\hline \multirow[t]{2}{*}{14} & $\begin{array}{l}\text { Mijn partner (thuis) staat positief t.o.v. mogelijke } \\
\text { veranderingen in het werk }\end{array}$ & .77 & .85 & \\
\hline & INTENTIE (RESULTAAT) & $\alpha=0.84$ & .18 & $4.25 / 4.14$ \\
\hline 15 & $\begin{array}{l}\text { Er is terugkoppeling over de stand van zake met } \\
\text { betrekking tot (Projectnaam). }\end{array}$ & .82 & .42 & $S D$ \\
\hline 16 & $\begin{array}{l}\text { Mijn verschillende werkzaamheden worden goed } \\
\text { gecoördineerd }\end{array}$ & .81 & .82 & $0.36 / 0.41$ \\
\hline 17 & $\begin{array}{l}\text { Productie is betrokken bij de ontwikkelingen binnen } \\
\text { de onderhoudsafdeling }\end{array}$ & .82 & .13 & \\
\hline 18 & $\begin{array}{l}\text { Mijn collega's voelen zich verantwoordelijk voor de } \\
\text { fouten die zij maken in hun werk }\end{array}$ & .82 & .34 & \\
\hline 19 & $\begin{array}{l}\text { Kostenbewustzijn is belangrijk voor mijn werkzaam- } \\
\text { heden }\end{array}$ & .82 & .25 & \\
\hline 20 & $\begin{array}{l}\text { Mijn collega's kunnen een actieve bijdrage leveren } \\
\text { aan (Projectnaam) }\end{array}$ & .80 & $.03 *$ & \\
\hline 21 & Ik ben betrokken bij het werk & .81 & .49 & \\
\hline 22 & Ik ga met plezier naar mijn werk & .82 & .37 & \\
\hline
\end{tabular}


23 Ik voel mij verantwoordelijk voor de fouten die ik maak in mijn werk

24 Ik sta open voor de mening van anderen

.83

.82

.81

.81

.80

.80

.83

.82

.81

.81

.81

.81

.80

.81

.18

\section{4 *}

.76

.38

.96

.21

.55

.81

.21

.67

.56

.51

.73

.51

36 Mijn collega's nemen initiatief in het werk om de nodige dingen op te pakken

${ }^{*}=$ significant verschil $p<.05,{ }^{* *}=$ significant verschil $p<.01$ 


\subsection{Casestudie 2: De kennisorganisatie in China $(N=37)$}

\subsubsection{De context}

Dit onderzoek heeft plaatsgevonden bij een buitenlandse vestiging van een internationale kennis- en dienstverlenende organisatie in China. De vestiging is verdeeld in twee aandachtsgebieden: 1) Dienstverlening en 2) Kennisontwikkeling. Binnen het onderdeel dienstverlening zijn twee afdelingen ondergebracht: de afdeling 'algemene zaken' waaronder financiële administratie, onderhoud, personeelszaken en het archief vallen en de afdeling 'dienstverlening' die dagelijks directe klantencontacten onderhoudt. Het onderdeel Kennisontwikkeling heeft 11 kennisgebieden die een grote mate aan zelfstandigheid kennen. In het totaal zijn 75 personen werkzaam op deze vestiging, waarvan 29 lokale krachten die in dienst zijn van de Chinese overheid. De voertaal is overwegend Engels en alle informatie wordt in het Engels gedeeld. Aan de inhoudelijke vraagstukken wordt in nauwe samenwerking met het moederbedrijf in Nederland invulling gegeven. Door het grote aantal Nederlandse expats is er tevens sprake van een grote wisseling van personeelsleden. Gemiddeld verblijven de medewerkers tussen de 3 en jaar in China.

China heeft de afgelopen jaren een ingrijpend economische veranderingsproces doorlopen. Mede als gevolg van dit veranderingsproces maakt China een periode van sterke economische groei door, die zorgt voor een toename van de welvaart en goede kansen biedt voor het Nederlandse bedrijfsleven. Duurzame ontwikkeling, milieuproblematiek, toenemende waterschaarste, de financiële dienstverlening, logistiek en distributie vormen aanknopingspunten voor het Nederlandse bedrijfsleven. Mede als gevolg van deze ontwikkelingen heeft de vestiging een strategisch meerjarenplan voor China opgesteld, waarin de samenhang tussen deze ontwikkelingen en de inrichting van de organisatie meer aandacht hebben gekregen. De leidraad daarbij is, dat het aanbod van de dienstverlening aansluit op de Chinese behoefte, wat ook invloed heeft op de relatie met het Nederlandse moederbedrijf. Daarnaast tracht men aan de hand van een herschikking van prioriteiten en doelstellingen meer slagkracht, samenwerking en evenwicht tussen de verschillende kennisgebieden te realiseren.

Ondanks het feit dat op deze vestiging reeds hard gewerkt is aan de realisatie van de beoogde doelstelling en het beantwoorden van de diverse vragen vanuit Nederland en China, is het management van mening dat de huidige interne organisatie, structuur en communicatie niet meer goed aansluiten bij de in het meerjarenplan opgestelde doelen en werkzaamheden. Voor de uitvoering van een meer geïntegreerd beleid en de implementatie van de in het meerjarenplan beschreven resultaten gaat de belangstelling (en behoefte) van de vestiging uit naar een meer functionele inrichting van de organisatie. Deze aanpassingen moeten leiden tot een flexibelere inrichting van de structuren om alle doelstellingen snel, efficiënt en effectief te kunnen realiseren. Tevens is gebleken, dat onderwerpen en uitgevoerde opdrachten van de diverse kennisgebieden sectoroverschrijdend zijn, waardoor goede onderlinge afstemming een extra toegevoegde waarde heeft voor de kwaliteit van werkzaamheden. Dat betreft vooral de interne processen zoals communicatie, een adequate inrichting van organisatie en processen en adequate functieprofielen. Vanuit de moederorganisatie in Nederland is deze aanpak omarmd en was de suggestie om een deel van de beschikbare tijd van de medewerkers over de kennisgebieden te verdelen en de werknemers daarmee flexibel in te zetten. 


\subsubsection{De opdracht}

Om de genoemde doelstellingen en het daaraan gekoppelde veranderingsproces te kunnen realiseren, heeft de vestiging in China om professionele ondersteuning vanuit de centrale personeelsafdeling gevraagd. Samen met de onderzoeker is de volgende opdracht opgesteld:

- Bevorder de kwaliteit en verbeter de efficiency van de werkprocessen binnen de vestiging.

- Ontwikkel een aantal mogelijkheden betreffende de herinrichting van de interne organisatie, structuur en communicatie en bepaal de personele gevolgen daarvan.

- Geef advies ten aanzien van de organisatorische opzet die nodig is voor een meer geïntegreerde werkwijze.

- Geef advies over de organisatie- /communicatiestructuur en over de inrichting van een functionele organisatie, uitgaande van de huidige personele bezetting.

Als uitkomst moest een ontwikkelplan worden opgesteld waarin zowel de organisatorische als de personele gevolgen omschreven zijn, alsook hoe deze kunnen aansluiten bij de door het management gedragen strategische beslissing. De opdracht richtte zich niet alleen op het wat er moet gebeuren om een gewenste verandering door te voeren, maar ook op het hoe. Tevens had men de wens om optimaal in te spelen op de lokale omstandigheden en maximaal van de kennis op de vestiging zelf te kunnen profiteren. Het management van de vestiging koos daarom nadrukkelijk voor een aanpak waarin alle medewerkers van de vestiging zelf veranderdoelen identificeren, uitvoeren en evalueren. De externe begeleiders vervullen daarbij de rol van vraagbaak, klankbord en coach.

\subsubsection{De aanpak}

In overleg met de centrale personeelsafdeling is door het management naar een methode gezocht die (organisatie)problemen analyseert en gedragsverandering meetbaar maakt zonder daarbij vanuit één specifiek theoretisch kader te handelen. Hun vraag aan de onderzoeker was om de reeds eerder onderzochte methode, de principes van IM in combinatie met de 'Reasoned Action Approach' (Rauner, Kok \& Taris, 2006) toe te passen op de beoogde doelstelling in China. Tijdens een bezoek van de vestigingsmanager aan Nederland is een globaal programma opgesteld, waarin een personeelsfunctionaris en de onderzoeker zelf betrokken waren. Conform eerder gemaakte afspraken tussen moederorganisatie en de vestiging zou verandering zoveel mogelijk op de werkvloer en in werktijd doorgevoerd worden om de daaraan gerelateerde onderwerpen te realiseren. Het voorstel was:

1. dat in overleg met de opdrachtgever vooraf wordt bekeken hoe een start kan worden gemaakt op de vestiging zelf, om tot een goed het verandertraject te kunnen komen;

2. dat de begeleiders zich vooral zullen richten op het aanscherpen van de gewenste visie/strategie en de organisatorische en personele gevolgen voor de vestiging;

3. dat er in een aantal workshops zal worden ingegaan op de strategische begrippen uit het strategisch meerjarenplan;

4. dat doelen, activiteiten, vaardigheden en resources en zo meer ter plekke georganiseerd worden; en

5. dat de uitkomst een plan van aanpak is, waarin de organisatorische en personele gevolgen voor de vestiging worden uitgewerkt. 
Door de onderzoeker is een opzet, conform de IM-aanpak en vergelijkbaar met die van het onderhoudsbedrijf uit casestudie 1 ingericht. Tevens is ervoor gekozen om voor de factoren uit het 'Reasoned Action Model' ('atitude', 'ervaren norm', 'ervaren controle' en 'intentie') van dezelfde (gevalideerde) vragenlijst als meetinstrument te gebruiken. Wel is bij de uitkomstcriteria ('intentie') conform de inzichten van Fishbein en Ajzen (2010) een onderscheid gemaakt tussen gedragsvoornemens ('intentie'), opvattingen over de huidige situatie ('beliefs nu') en opvattingen over de toekomst ('beliefs toekomst'). Hierdoor kunnen niet alleen ervaren barrières beter worden ingekaderd, maar dit geeft ook duidelijker inzicht in voorgenomen gedrag. Ook zijn de vragen vertaald in het Engels. De vragen betreffende de specifieke gedragsindicatoren worden later, na een vooronderzoek, door de betrokkenen zelf ingevuld. Globaal had de interventie de volgende opzet (tabel 4.5).

Tabel 4.5: Globale opzet en inhoudelijke programmaonderdelen

\begin{tabular}{|c|c|c|c|c|}
\hline In de week vooraf & Zaterdag / Zondag & Maandag & Dinsdag & Woensdag \\
\hline $\begin{array}{l}\text { Doornemen van } \\
\text { achtergrond- } \\
\text { informatie en } \\
\text { ontwikkelen van } \\
\text { het materiaal. }\end{array}$ & $\begin{array}{l}\text { - Vertrek uit NL. } \\
\text { - Kort overleg met } \\
\text { de opdrachtgever } \\
\text { en vaststellen van } \\
\text { het definitieve } \\
\text { programma. }\end{array}$ & $\begin{array}{l}\text { Plenaire uitleg } \\
\text { voor het perso- } \\
\text { neel. } \\
\text { - Eerste gesprekken } \\
\text { met de opdracht- } \\
\text { gever en het MT. } \\
\text { - Formeren van een } \\
\text { werkgroep en } \\
\text { start met Indivi- } \\
\text { duele gespreken. }\end{array}$ & $\begin{array}{l}\text { - In het MT uitwer- } \\
\text { ken van vi- } \\
\text { sie/strategie naar } \\
\text { de organisatori- } \\
\text { sche en personele } \\
\text { gevolgen. } \\
\text { - Raamwerk voor } \\
\text { de verander- } \\
\text { doelstelling vast- } \\
\text { leggen. } \\
\text { - In interviews } \\
\text { barrières opspo- } \\
\text { ren. } \\
\text { - Uitwerken van } \\
\text { een vragenlijst. }\end{array}$ & $\begin{array}{l}\text { Houden van } \\
\text { interviews en } \\
\text { workshops con- } \\
\text { form 'Reasoned } \\
\text { Action'-factoren. } \\
\text { - Uitzetten van de } \\
\text { vragenlijst. }\end{array}$ \\
\hline Donderdag & Vrijdag & Zaterdag / Zondag & Maandag & Dinsdag \\
\hline $\begin{array}{l}\text { - Vervolg inter- } \\
\text { views. } \\
\text { - Analyse van de } \\
\text { werkprocessen op } \\
\text { de diverse afde- } \\
\text { lingen. } \\
\text { - Invoer van de } \\
\text { vragenlijst en } \\
\text { verwerking van } \\
\text { alle gegevens. }\end{array}$ & $\begin{array}{l}\text { Voorbereiding van } \\
\text { de rapportage. } \\
\text { - Plenaire presenta- } \\
\text { tie van de uitkom- } \\
\text { sten. } \\
\text { - Met het MT en } \\
\text { een aantal sta- } \\
\text { keholders uitwer- } \\
\text { ken van een ver- } \\
\text { anderstrategie. }\end{array}$ & $\begin{array}{l}\text { Presentatie van } \\
\text { de uitkomsten } \\
\text { aan opdracht- } \\
\text { gever en MT. } \\
\text { - Uitwerken van de } \\
\text { gekozen oplos- } \\
\text { sings-richting. } \\
\text { - Definitieve } \\
\text { rapportage uit- } \\
\text { werken. }\end{array}$ & $\begin{array}{l}\text { Presentatie van } \\
\text { de uitkomsten } \\
\text { aan mede- } \\
\text { werkers. } \\
\text { - Werken in sub- } \\
\text { groe- } \\
\text { pen/workshops } \\
\text { aan oplossings- } \\
\text { richtingen. } \\
\text { - Presentatie van } \\
\text { de uitkomsten } \\
\text { door de subgroe- } \\
\text { pen. }\end{array}$ & $\begin{array}{l}\text { - Uitwerken van de } \\
\text { verdere verander- } \\
\text { strategie in het } \\
\text { MT. } \\
\text { - Verdere afspraken } \\
\text { vastleggen. } \\
\text { - Vertrek (in de } \\
\text { avond of de vol- } \\
\text { gende ochtend). }\end{array}$ \\
\hline
\end{tabular}

\subsubsection{Uitvoering en meetmomenten}

Het programma zoals door de onderzoeker voorgesteld, is door het management ter plaatse geaccordeerd. Na een eerste plenaire bijeenkomst met alle personeelsleden waarin doelstelling, inhoud en proces zijn toegelicht zijn de globale verbeterpunten in een werkgroep geïdentificeerd. In een 'brown papersessie' zijn aandachtsgebieden geclusterd en zoveel mogelijk geconcretiseerd. Hiervoor heeft iedere deelnemer op postitstickers in eigen bewoordingen een verbeterpunt opgeschreven en op een muur geplakt. Vervolgens heeft de groep alle punten bekeken en waar nodig toelichting gevraagd. De opmerkingen die naar mening van de deelnemers overeenkwamen, zijn geclusterd en uiteindelijk mocht iedere deelnemer de clusters beoordelen op belangrijkheid. De uitkomst was een weergave van de aandachtsgebieden die volgens de werk- 
groep tot een betere organisatie kunnen leiden. Globaal zijn de volgende punten geidentificeerd:

- Er is een strategisch plan, maar de doelstellingen zijn onvoldoende concreet uitgewerkt.

- De indeling van de organisatie is niet duidelijk en bemoeilijkt de samenwerking.

- De informatievoorziening is niet optimaal.

- Problemen worden niet besproken.

- De manier van aansturing door het management is erg uiteenlopend.

- Er wordt onvoldoende samengewerkt.

- Afspraken zijn niet helder of worden niet nagekomen.

- Door de hokjesindeling wordt niet goed samengewerkt.

- Ontwikkeling van mensen krijgt onvoldoende aandacht.

- Het is onduidelijk wat het management wil.

Vervolgens heeft de onderzoeker individuele en met het lokaal personeel groepsgewijze gesprekken gevoerd, waarin problematiek, veranderdoelstelling, barrières, bevorderende factoren en gedragscriteria zijn besproken. Uit de gesprekken is duidelijk geworden, dat het personeel redelijk tevreden was met het werk en de organisatie. Wel is het management als tamelijk 'onzichtbaar' ervaren en was er behoefte aan duidelijker structuren. Juist omdat er vanuit de centrale organisatie in Nederland bezuinigingen zijn aangekondigd, had met behoefte aan een duidelijke koers voor de toekomst.

Ook waren er ideeën over hoe de samenwerking beter kon verlopen, maar had men het gevoel, dat er hiervoor te weinig aandacht en steun was vanuit het management. Door een sterk informele communicatiestructuur heeft men het gevoel niet goed op de hoogte van de actualiteit te zijn. Het behalen van resultaten was redelijk vrijblijvend en er wordt achteraf onvoldoende geëvalueerd, waarom iets wel dan wel niet heeft gewerkt. Ondanks gemeenschappelijke borrels en bijeenkomsten was er een laag gevoel van samenhorigheid. In een bijeenkomst met het MT is met behulp van managementliteratuur, informatie op internet en de deskundigheid van de personeelsfunctionaris en de onderzoeker voor een raamwerk gekozen, dat het meest aansluit bij de veranderbehoefte van de organisatie. In dit geval is gekozen voor het ' $7 S^{\prime}$ '-managementmodel van McKinsey (Waterman, Peters \& Philips; 1980; Waterman, 1982; Peters \& Waterman, 1982). Het model is aan de hand van de geraadpleegde literatuur voor de betrokken deelnemers in een presentatie uitgewerkt (zie figuur 4.1).

De keuze voor dit model doet er geen uitspraak over of dit een juist en valide managementmodel is, maar is gemaakt, omdat het goed bij de beleving van de betrokken personen aansloot en de mogelijkheid bood om een aantal harde en zachte veranderdoelen op te stellen. Daarbij richten zich de harde elementen op zaken waar een organisatie direct invloed op kan uitoefenen. De zachte elementen zijn meer abstract in een organisatie aanwezig en zijn terug te vinden in de organisatiecultuur. Tot de harde factoren in het model worden 'Strategy', 'Structure' en 'Systems' gerekend. De zachte factoren zijn 'Style', 'Shared Values', 'Skills' en 'Staff' (Assen van, Berg van den \& Pietersma, 2008).

Het begrip 'Strategy' duidt hier op de voorgenomen acties van management/organisatie: Welke doelen heeft men zich gesteld en hoe denkt men die te realiseren? In welke sectoren gaan we investeren? Waar richten we onze energie op? Op welke markt gaan we ons bewegen, met welk product? Bij 'Structure' gaat het veel 
meer om de inrichting van de organisatie: taakverdeling, coördinatie, informatievoorziening, lijn/staffuncties. Hoe is de organisatie georganiseerd? Is het een gecentraliseerde of gedecentraliseerde, een hiërarchie of een platte organisatie? 'Systems' verwijst naar de formele en informele procedures binnen de organisatie, bijvoorbeeld: administratie- en budgetteringssystemen, orderafwikkeling, klachtenbehandeling, planning en prioriteitstelling, beoordelingssystemen, promotielijnen, manieren van vergaderen, planning en controle.

\section{Figuur 4.1: Uitwerking 7-S Model}

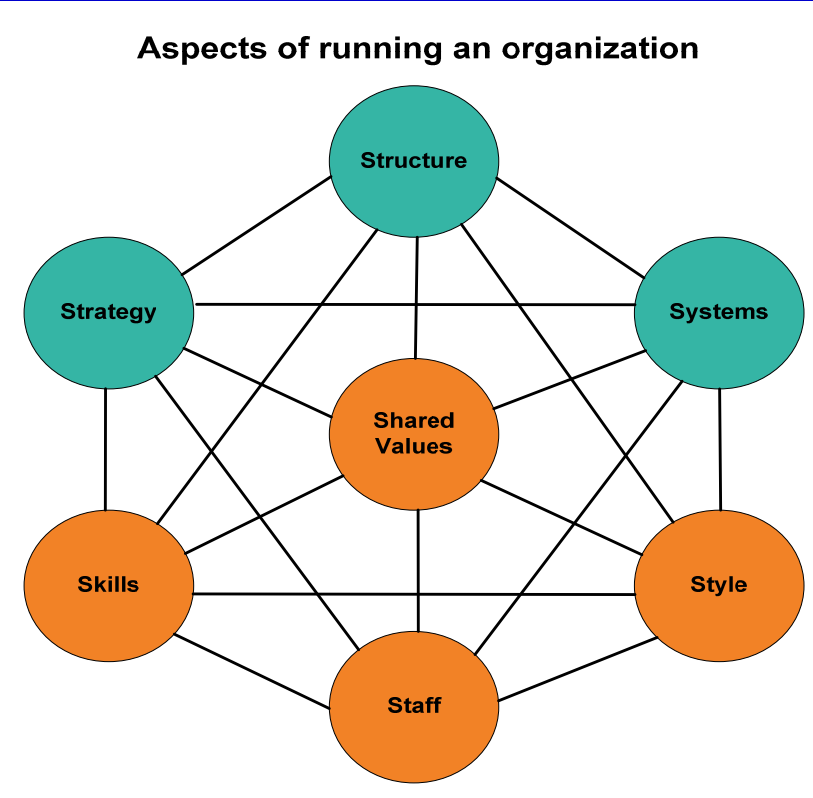

Strategy: Plan or course of action leading to the allocation of an organisation's finite resources to reach identified goals

Structure: Salient features of the organisational chart (e.g. degree of hierarchy, presence of internal market, extent of centralisation/ decentralisation) and interconnections within the organisation

Systems: Procedures and routine processes, including how information moves around the organisation

Staff: Personnel categories within the organisation, e.g. nurses, doctors, technicians Style (culture): Characterisation of how key managers behave in order to achieve the organisation's goals; the dominant values and beliefs, and norms, which develop over time and become relatively enduring features of organizational life

Shared values: The significant meanings or guiding concepts than an organisation imbues in its members

Skills: Distinctive capabilities of key personnel and the organisation as a whole

De factor 'Style' komt tot uiting in het gedrag van het management en medewerkers. Het is de manier van (samen)werken, die kenmerkend is voor de organisatie, zich uitend in kleine en grote dingen, bijvoorbeeld het snel aanpakken van de mogelijkheden of eerst alle risico's doorrekenen; duur, goed verzorgd meubilair of een 
sobere inrichting. Een ander woord voor 'Style' is cultuur. 'Shared Values' verwijst naar de binnen de organisatie door iedereen gedeelde waarden en is een kernachtige aanduiding voor: wat wil de organisatie en waar staat de organisatie voor? Hierin worden de idealen van de organisatie verwoord. De factor 'Skills' verwijst naar de sleutelvaardigheden van een organisatie. Wat kan de organisatie goed, waarin blinkt zij uit? Dat kan dienstverlening zijn, innovatievermogen, marketing, degelijkheid of bijvoorbeeld producttechnologie. Het begrip 'Staff' heeft hbetrekking op de categorieën functies en richt zich op zowel de 'harde' kant (zoals vakkennis, beloning, opleiding, beoordeling en selectie) alsook op de 'zachte' kant (zoals moraal, motivatie en gedrag).

Het ' $7 S$ '-model analyseert aan de hand van deze zeven factoren de prestaties van een organisatie. Deze factoren moeten als integraal worden beschouwd en beïnvloeden elkaar onderling. Om een effectieve en efficiënte organisatie te realiseren moet dus met alle factoren rekening worden gehouden. De benadering van elk van de zeven factoren beïnvloedt ook de andere zes en moet deze daarom ook ondersteunen. Op deze manier worden alle factoren, en daarmee de gehele organisatie, versterkt. De kenmerken hiervan zijn:

- Samenhang: iedere verandering in een van de S-en heeft ook een verandering in de andere zes S-en tot gevolg.

- Evenwicht: iedere ' $S$ ' is even belangrijk; dat vraagt een consistente en evenwichtige afstemming tussen de zeven parameters.

- Heterogeniteit: het model heeft zowel betrekking op formele als op informele aspecten.

Het model maakt duidelijk dat er geen uniforme manier van slagen is, die op elke organisatie kan worden toegepast, maar dat sturing wel degelijk mogelijk is. Belangrijk blijft de onderlinge samenhang tussen alle factoren. In een goed functionerende organisatie komen alle aspecten uit de verschillende factoren met elkaar overeen. Belangrijk is dus dat er synergie moet zijn tussen alle factoren.

In vervolggesprekken met de betrokken medewerkers is het meetinstrument verder uitgewerkt en zijn specifieke gedragsindicatoren gedefinieerd. Uiteindelijk is ervoor gekozen om de vragenlijst niet te gebruiken voor de lokale personeelsleden die in dienst zijn van de Chinese overheid, omdat er grote twijfel was over de betrouwbaarheid van hun antwoorden. Immers, alle medewerkers staan onder strikte controle van de Chinese overheid en de antwoorden zouden meer de partijlijn weergeven dan de individuele opvattingen. Dit beeld is ook in de voorafgaande gesprekken bevestigd, waarin de in rang hoogste' persoon als spreekbuis fungeerde en veel antwoorden waren 'ik weet niet' of 'ja goed' of waren algemeen geformuleerd. Tevens kon niet worden gegarandeerd, dat de lokale medewerkers de vragenlijst individueel zonder bemoeienis van anderen zouden kunnen invullen. De definitieve vragenlijst is onder alle andere aanwezige personeelsleden $(N=37$ ) uitgedeeld en verwerkt (respons $N=26)$. De uiteindelijke vragenlijst bestond naast een drietal algemene vragen (geslacht, leeftijd en opleiding) uit 30 andere vragen. Deze waren onderverdeeld in 14 vragen over de aspecten uit het '7$S^{\prime}$ - model betreffende de huidige situatie en de 16 reeds gevalideerde vragen die betrekking hebben op de aspecten van het 'Reasoned Action Model'. ). Ter onderbouwing van de constructie van het meetinstrument is per schaal de Cronbach's $\alpha$ berekend. Deze varieerde van .63 tot .78 (zie tabel 4.8 ), wat op een goede schaalconstructie duidt. 
De resultaten zijn aan de hand van de hoogte van de score en de standaarddeviatie kwalitatief onderzocht met als doel mogelijke barrières op te sporen en de thema's voor mogelijke interventies te identificeren.

In een gezamenlijke bijeenkomst met het management, enkele werknemers, de personeelsfunctionaris en de onderzoeker zijn de uitkomsten (op het niveau van gemiddelde, standaarddeviatie) kwalitatief geanalyseerd. Hierbij is aan de hand van grafiek 4.2 eerst gekeken naar de meest extreem scorende items $(>3$ of $<2$ ) met een standaarddeviatie kleiner dan 1.5.

\section{Grafiek 4.2: gemiddelde en standaarddeviatie per item.}

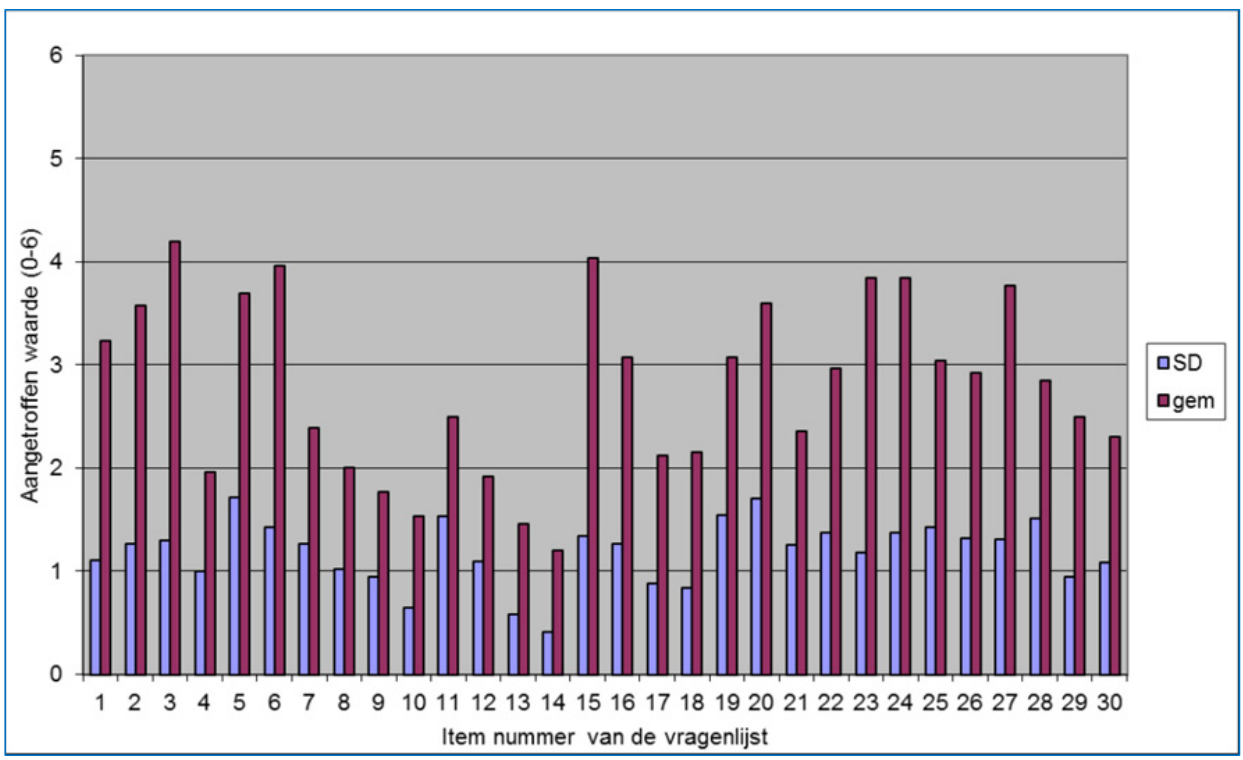

Vervolgens zijn de geselecteerde items geordend en in de werkgroep besproken. Met betrekking tot het 7-S-model was door de betrokken personen aangegeven dat:

- er duidelijke functie-indelingen en beschrijvingen zijn met betrekking tot de invulling van de eigen werkzaamheden ('Staff'); .

- procedures en gedeelde waarden en normen minder duidelijk omschreven zijn;

- de steun door de leidinggevende als matig tot slecht wordt ervaren; en

- er behoefte is aan verbetering van de eigen vaardigheden.

De uitkomsten uit de vragenlijst gebaseerd op het 'Reasoned Action Model' (tabel 4.6) uit de 'Reasoned Action Approach' van Fishbein en Ajzen (2010) laten zien, dat een hoge mate aan veranderbereidheid ('attitude') aanwezig is. Een groot deel van de respondenten geeft aan weinig invloed op de situatie uit te kunnen oefenen ('ervaren contro$\left(e^{\prime}\right)$ en de sociale steun ('ervaren norm') worden als matig tot laag ervaren. De meerderheid is ervan overtuigd in de komende zes maanden zelf aan verbeteringen te zullen werken ('belief toekomst') en de huidige situatie wordt als onprettig ervaren ('belief $\left.n u^{\prime}\right)$. 
In een plenaire bijeenkomst zijn de resultaten vant deze vragenlijst gepresenteerd en aan de doelstellingen uit het meerjarenplan gekoppeld. Vervolgens heeft het MT samen met een aantal stakeholders uit de organisatie de veranderdoelstelling verder uitgewerkt en zijn de uitkomsten van de eerste meting aan alle medewerkers gepresenteerd.

De conclusie was dat de aandacht moest worden gericht op:

- het verbeteren van de werknemerstevredenheid;

- de concretisering van onderwerpen zoals strategie, structuur, stijl, gedeelde waarden en vaardigheden;

- het bieden van meer mogelijkheden om verbeteringen in de organisatie te realiseren; en

- meer eenheid in stijl van en ondersteuning door de leidinggevende.

In kleine werkgroepen is er vervolgens naar gekeken, welke concrete veranderingen in het dagelijkse werk noodzakelijk zijn om de gewenste doelstellingen te bereiken. ledere werkgroep heeft een korte presentatie voorbereid en deze plenair toegelicht. Vervolgens is in het MT met een aantal stakeholders de definitieve veranderstrategie besproken en vastgesteld. Samen met de personeelsfunctionaris en de onderzoeker zijn activiteiten uitgewerkt, die dit proces verder moeten ondersteunen. Uiteindelijk zijn tien aanbevelingen opgesteld (vertaald uit het Engels):

1. Richt meer aandacht op 'Shared Values' door het opstellen van haalbare doelstellingen en resultaten (ook op de andere factoren uit het ' $7 \mathrm{~S}$ '-model).

2. Voer een meer op delegeren gerichte managementstijl in en maak personen meer verantwoordelijk voor hun eigen taken.

3. Maak aanbeveling 1 en 2 tastbaar in concreet waarneembaar gedrag en bevorder voorbeeldgedrag.

4. Definieer projectmatig werken en maak het duidelijk in vaardigheden, gedrag en verantwoordelijkheden.

5. Geef en neem verantwoordelijkheid en beloon dat ('ownership').

6. Stimuleer het probleemoplossend vermogen.

7. Investeer in het werken in teams en zorg voor de goede afwerking van werkzaamheden.

8. Benut de aanwezige informatie en train mensen in het zoeken en vinden.

9. Interpreteer niet maar vraag wat er aan de hand is.

10. Richt je op het positieve en werk naar oplossingen.

leder team heeft aan de hand van deze aanbevelingen de eigen 'organisatie' onderzocht en concrete verbetermaatregelen opgesteld. Afgesproken is dat na vijf maanden opnieuw de vragenlijst onder alle medewerkers zou worden voorgelegd en dat door de werkgroep daarover terugkoppeling zou worden gegeven.

\subsubsection{Uitkomsten}

Evenals bij casestudie 1 was de opdrachtgever zelf verantwoordelijk voor het opstellen en de uitvoering van de interventies; de onderzoekers hadden daarop geen invloed. Wel is vanuit de moederorganisatie in Nederland en de betrokken personeelsfunctionaris ondersteuning geboden in de vorm van coaching, ideeën aandragen en advisering over gekozen interventies. Na een periode van zes maanden vond opnieuw een meting 
plaats (respons van 92\%) en zijn de uitkomsten met de werkgroepleden en het management besproken (zie tabel 4.6).

Tabel 4.6 : Gemiddelde en Standaarddeviatie voor meting 1 \& 2

\begin{tabular}{lcccccc} 
& $\begin{array}{c}\text { SD } \\
\text { Meting } \\
\mathbf{1}\end{array}$ & $\begin{array}{c}\text { Gemiddelde } \\
\text { (range 1-6) } \\
\text { Meting 1 }\end{array}$ & $\begin{array}{c}\text { N } \\
\text { Meting } \\
\mathbf{1}\end{array}$ & $\begin{array}{c}\text { SD } \\
\text { Meting } \\
\mathbf{2}\end{array}$ & $\begin{array}{c}\text { Gemiddelde } \\
\text { (range 1-6) } \\
\text { Meting 2 }\end{array}$ & $\begin{array}{c}\text { N } \\
\text { Meting } \\
\mathbf{2}\end{array}$ \\
\hline Ervaren situatie Nu ('Beliefs') & .84 & 3.71 & 26 & .47 & 4.35 & 24 \\
\hline $\begin{array}{l}\text { Verwachting over de Toekomst } \\
\text { ('Beliefs') }\end{array}$ & .54 & 5.28 & 25 & .35 & 5.35 & 23 \\
\hline Attitude & .82 & 4.50 & 24 & .55 & 5.01 & 22 \\
\hline Ervaren Controle & .97 & 3.34 & 25 & .65 & 4.65 & 23 \\
\hline Ervaren Norm & 1.07 & 3.69 & 25 & .72 & 4.17 & 23 \\
\hline Intentie & .87 & 4.44 & 25 & .69 & 4.91 & 23 \\
\hline
\end{tabular}

Omdat de vragenlijst anoniem is verwerkt en de twee metingen niet naar een specifiek individu kon worden herleid, was een statistische analyse op individueel niveau niet mogelijk (gepaarde $t$-test), temeer omdat er in de tussentijd ook personele wisselingen hebben plaatsgevonden en men alle medewerkers aan het onderzoek wilde laten deelnemen. Derhalve zijn ook bij dit onderzoek de demografische gegevens van meting een en meting twee (leeftijd, opleiding en sekse) op verschillen onderzocht (zie tabel 4.7). De uitkomst laat zien, dat er geen significant verschil bestaat tussen de demografische kenmerken van de respondenten van meting 1 en meting 2. Voor verder onderzoek naar de effecten en de ontwikkelingen kan daarom worden uitgegaan dat de steekproef voor beide metingen vergelijkbaar met elkaar is.

Tabel 4.7: Analyse op de algemene gegevens tussen meting 1 en meting 2

\begin{tabular}{lcccccr}
\hline T-Test & $\boldsymbol{N}$ & Missing & df & $\boldsymbol{t}$ & $\boldsymbol{F}$ & $\boldsymbol{p}$-waarde \\
\hline Leeftijd & 31 & 19 & 29 &,- 232 &, 006 &, 818 \\
\hline Chi-kwadraat toets & $\boldsymbol{N}$ & Missing & df & Pearson Chi-Kwadraat & Significantie \\
\hline Geslacht & 39 & 11 & 1 &, 018 &, 894 \\
\hline Opleiding & 39 & 11 & 2 &, 003 &, 999 \\
\hline (p<.05 = significant verschil) & & & & & \\
\hline
\end{tabular}

Een analyse van de effecten van de uitgevoerde interventies heeft in eerste instantie plaatsgevonden op de somscores van de variabelen uit het 'Reasoned Action Model'. Hiervoor is gebruik gemaakt van een multivariate variantieanalyse (MANOVA). Grafiek 4.3 presenteert de betreffende gemiddelden. Er valt een lichte stijging van de scores op de betreffende concepten waar te nemen en er is sprake van een significant verschil tussen de metingen, multivariate $F(6,37)=.004$ behalve voor de variabelen over de toekomstverwachting ('b elief toekomst') en steun door leiding en de directe collega's ('norm'). 
De grootste verandering is voor de factoren 'ervaren controle', 'attitude' en 'intentie' gevonden. Tevens gaven de deelnemers aan, dat dit traject ertoe heeft bijgedragen, dat zij zelf meer verantwoordelijkheid voelen voor de gewenste verandering en ook het gevoel hebben over de nodige middelen te kunnen beschikken. Een opmerkelijk detail is, dat de uitkomsten van de analyse na de eerste interventie tot veel discussie hebben geleid tussen medewerkers en management. De medewerkers hadden het gevoel, dat er nu echt iets moest veranderen en dat de tijd rijp was voor vernieuwing. Hun positieve houding ten opzichte van de ingeslagen koers is toegenomen en het werken met concrete resultaatafspraken heeft de betrokken medewerkers het gevoel gegeven zelf invloed op hun werk uit te kunnen oefenen.

Naast de hoofdeffecten wilde de opdrachtgever ook een analyse per item voor de uitkomstvariabelen. Daarvoor is gebruik gemaakt van een $t$-test (zie tabel 4.8). De uitkomsten laten zien dat ook op het niveau van de afzonderlijke vragen matige verschillen tussen meting 1 en meting 2 waar te nemen zijn (minder dan één punt verschil). Slechts voor zes vragen werd een significant verschil $(p<.05)$ aangetroffen.

\section{Grafiek 4.3: Weergave voor- en nameting}




Een kwantitatieve beoordeling van de uitkomsten op spreiding en gemiddelde laat zien dat:

- de spreiding in de antwoorden tussen de diverse respondenten in de weergave van hun antwoorden minder groot is geworden (personen zijn het dus meer met elkaar eens);

- de duidelijkheid betreffend strategie, functie-indeling en steun door de leiding niet significant is toegenomen;

- de behoefte om meer gesteund te worden door de leiding is gegroeid;

- er nog meer moet worden geïnvesteerd in het waarom en het wat van de gewenste verandering; en

- de leiding meer initiatief moet tonen.

Tabel 4.8: Overzicht van de vragenlijst

\begin{tabular}{|c|c|c|c|}
\hline & Cronbach's $\alpha$ & $\begin{array}{r}t \text {-test / } \\
\text { ANOVA } \\
\text { meting 1-2 }\end{array}$ & $\begin{array}{r}\text { Gemiddelde } \\
\text { (Range }=1-6 \text { ) } \\
\text { Meting 1/2 }\end{array}$ \\
\hline ATTITUDE & $\alpha=0.78$ & $* / * *$ & $4.50 / 5.01$ \\
\hline $\begin{array}{l}\text { For me to work on a better organization has direct influence on } \\
\text { my performance (negative - positive) }\end{array}$ & .76 & $/ * *$ & $S D$ \\
\hline I find working on organizational issues (worthless - valuable) & .77 & $* /$ & $0.82 / 0.55$ \\
\hline $\begin{array}{l}\text { For me to work on organizational development is (unpleasant - } \\
\text { pleasant) }\end{array}$ & .67 & & \\
\hline $\begin{array}{l}\text { To work on a better organization during the next } 6 \text { month will be } \\
\text { (worthless - valuable) }\end{array}$ & .65 & $/^{*}$ & \\
\hline ERVAREN CONTROLE & $\alpha=0.63$ & $* / * *$ & $3.34 / 4.65$ \\
\hline $\begin{array}{l}\text { For me to work on the development of this post is (difficult - } \\
\text { easy) }\end{array}$ & .55 & $/ * *$ & $S D$ \\
\hline $\begin{array}{l}\text { It's up to me whether I will put effort in achieving a better organ- } \\
\text { ization (disagree - agree) }\end{array}$ & .43 & $* * / * *$ & $0.97 / 0.65$ \\
\hline $\begin{array}{l}\text { There are possibilities for me to work on developing the organi- } \\
\text { zation (none - many) }\end{array}$ & .62 & $/ * *$ & \\
\hline $\begin{array}{l}\text { The means to contribute on organizational development are } \\
\text { (none-many) }\end{array}$ & .59 & $/ * *$ & \\
\hline SUBJECTIEVE NORM & $\alpha=0.66$ & & $3.69 / 4.17$ \\
\hline $\begin{array}{l}\text { Most colleagues are supportive when I bring up organizational } \\
\text { issues (never - always) }\end{array}$ & .62 & $/^{*}$ & $S D$ \\
\hline $\begin{array}{l}\text { My direct supervisor stimulates me to contribute in improving } \\
\text { the organization (false - true) }\end{array}$ & .59 & & $1.07 / 0.72$ \\
\hline $\begin{array}{l}\text { Others expect me to contribute to organizational development } \\
\text { (false - true) }\end{array}$ & .65 & $/^{*}$ & \\
\hline $\begin{array}{l}\text { Most of the members of the post want to work on a better } \\
\text { organization (none - many) }\end{array}$ & .49 & & \\
\hline INTENTIE (RESULTAAT) & $\alpha=0.73$ & $/^{*}$ & $4.44 / 4.91$ \\
\hline $\begin{array}{l}\text { That I will put effort in a more effective organization is (unlikely - } \\
\text { likely) }\end{array}$ & .72 & & $S D$ \\
\hline $\begin{array}{l}\text { I am confident that I will contribute to organizational develop- } \\
\text { ment (false - true) }\end{array}$ & .66 & $/^{*}$ & $0.87 / 0.69$ \\
\hline $\begin{array}{l}\text { Next year I will have contributed to an improved organization (I } \\
\text { will not - I will) }\end{array}$ & .60 & & \\
\hline $\begin{array}{l}\text { I intent to work on a better organization during the next } 6 \text { month } \\
\text { (disagree - agree) }\end{array}$ & .65 & & \\
\hline
\end{tabular}


Een analyse op het gekozen '7-S'-model (tabel 4.9: 'Belief Nu' en 'Belief Toekomst') laat zien, dat er een verschil is tussen meting 1 en 2 voor 'Systems', 'Style' en 'Skills'. Vooral procedures en processen zijn nu duidelijker geworden; medewerkers zijn van mening, dat zij worden gestimuleerd om resultaten te behalen. Ook zijn de deelnemers van mening over voldoende kennis en vaardigheden te beschikken om hun werk en de gewenste verandering uit te kunnen voeren. Tegelijkertijd geven zij aan, dat er nog de nodige verbetering door te voeren is. Dit heeft vooral betrekking op procedures en structuren, steun door de leiding, het ontwikkelen van vaardigheden en de koppeling tussen het project en de individuele taakstelling. Samen met het management zijn de uitkomsten geanalyseerd en is besloten het project verder door te zetten, een beslissing die door alle betrokkenen als positief is ervaren. Kort na deze evaluatie heeft het topmanagement van de vestiging besloten om de organisatie te verlaten, omdat deze een 'betere' functie bij een andere organisatie heeft aangeboden gekregen. Hierdoor viel een belangrijke aanjager voor de ingezette koers weg. Het zittende management was niet in staat om de ingeslagen koers vol te houden, waardoor een derde meting uiteindelijk niet is verricht. Bovendien heeft de centrale organisatie in Nederland een aantal medewerkers vervangen, een interventie die de samenstelling van de medewerkers op de vestiging duidelijk heeft beïnvloed.

Tabel 4.9: Uitkomsten op het 7-S Model van McKinsey

\begin{tabular}{|c|c|c|c|c|}
\hline \multicolumn{5}{|c|}{ Huidige ervaren situatie (Beliefs $\mathrm{Nu}$ ) } \\
\hline Criterium & Vraag & $\begin{array}{l}\text { t-test } \\
\text { (meting } \\
1-2 \text { ) }\end{array}$ & $\begin{array}{l}\text { Gemiddelde } \\
\text { (Range }=1-6 \text { ) } \\
\text { Meting } 1 / 2\end{array}$ & $\begin{array}{l}S D \\
\text { Meting } 1 / 2\end{array}$ \\
\hline Strategy & $\begin{array}{l}\text { We have developed strategies to reach identi- } \\
\text { fied goals }\end{array}$ & & $3.77 / 4.29$ & $1.11 / 0.86$ \\
\hline Structure & $\begin{array}{l}\text { We have a clear and transparent structure of } \\
\text { organization }\end{array}$ & & $3.42 / 4.13$ & $1.27 / 0.95$ \\
\hline Systems & $\begin{array}{l}\text { We have well known procedures and process- } \\
\text { es, including how information moves around } \\
\text { the organization }\end{array}$ & * & $2.81 / 4.17$ & $1.29 / 0.81$ \\
\hline Staff & $\begin{array}{l}\text { We have personal categories within the organ- } \\
\text { ization (e.g. assistant, secretary, deputy head, } \\
\text { head...) }\end{array}$ & & $5.04 / 5.08$ & $0.99 / 0.83$ \\
\hline Style & $\begin{array}{l}\text { The behavior of our superiors stimulates us to } \\
\text { achieve specified goals }\end{array}$ & * & $3.31 / 3.71$ & $1.71 / 1.08$ \\
\hline Values & $\begin{array}{l}\text { We have shared values with respect to behav- } \\
\text { ior, tasks and goals }\end{array}$ & & $3.04 / 4.04$ & $1.43 / 1.04$ \\
\hline Skills & $\begin{array}{l}\text { We have enough skills en capabilities to do our } \\
\text { work right }\end{array}$ & $*$ & $4.62 / 5.04$ & $1.26 / 0.75$ \\
\hline
\end{tabular}




\begin{tabular}{|c|c|c|c|c|}
\hline Criterium & Vraag & $\begin{array}{l}t \text {-test } \\
\text { (meting } \\
1-2 \text { ) }\end{array}$ & $\begin{array}{l}\text { Gemiddelde } \\
\text { (Range }=1-6 \text { ) } \\
\text { Meting 1 } / 2\end{array}$ & $\begin{array}{l}\text { SD } \\
\text { Meting } 1 / 2\end{array}$ \\
\hline Strategy & $\begin{array}{l}\text { For me to have a defined strategy to reach } \\
\text { identified goals is }\end{array}$ & & $5.00 / 5.29$ & $1.02 / 0.81$ \\
\hline Structure & $\begin{array}{l}\text { For me to have a clear and transparent structure } \\
\text { of organization is }\end{array}$ & & $5.23 / 5.37$ & $0.95 / 0.77$ \\
\hline Systems & $\begin{array}{l}\text { To have well known procedures and processes, } \\
\text { including how information moves around the }\end{array}$ & & $5.46 / 5.54$ & $0.65 / 0.51$ \\
\hline Staff & $\begin{array}{l}\text { For me to have personal categories within the } \\
\text { organization (e.g. assistant, secretary, deputy } \\
\text { head, head...)organization is }\end{array}$ & & $4.50 / 4.50$ & $1.53 / 1.29$ \\
\hline Style & $\begin{array}{l}\text { To be stimulated by my superior to achieve } \\
\text { specified goals is }\end{array}$ & $*$ & $5.08 / 5.58$ & $1.09 / 0.50$ \\
\hline Values & $\begin{array}{l}\text { For me to have shared values with respect to } \\
\text { behavior, tasks and goals is }\end{array}$ & & $5.04 / 5.29$ & $0.58 / 0.81$ \\
\hline Skills & $\begin{array}{l}\text { To have enough skills and capabilities to do my } \\
\text { work right is }\end{array}$ & & $5.08 / 5.83$ & $0.41 / 0.39$ \\
\hline
\end{tabular}

In dit deelonderzoek is aangetoond, dat met behulp van de ontwikkelde vragenlijst gebaseerd op de 'Reasoned Action Approach' (Fishbein \& Ajzen, 2010) en een op de principes van 'Intervention Mapping' gebaseerde procesaanpak de effectiviteit van een gedragsinterventie kan worden gemeten en de belemmerende en bevorderende factoren die van invloed zijn op de uitkomst van de interventie, inzichtelijk maakt (deelvraag 1 en 2). De validiteit blijft ook bij dit deelonderzoek een belangrijk aandachtpunt. Het gekozen ' $7 S^{\prime}$-model geeft weinig inzicht in specifiek gedrag en de mogelijke relatie met een beoogd resultaat. Ook is duidelijk geworden, dat de terugkoppeling over deze factoren en over de voortgang van het proces (deelvraag 4) een positieve invloed heeft op de kwaliteit van interventie en het resultaat. 


\subsection{Casestudie 3: De kennisorganisatie in Canada $(N=20)$}

\subsubsection{De Context}

Dit onderzoek heeft plaatsgevonden bij een kleine vestiging in Canada van de internationale kennis- en dienstverlenende organisatie uit de vorige casestudie. Vanouds bestaat een goede relatie tussen Nederland en Canada. Vooral de bevrijding van Nederland in 1944/1945 en de naoorlogse Nederlandse emigratie richting Canada zijn hiervan de oorzaak. Momenteel wonen naar schatting ruim 900.000 personen van Nederlandse afkomst in Canada. Daarnaast bestaan er tal van (handels)contacten tussen beide landen. De werkzaamheden van de vestiging in Canada omvatten naast handelstaken ook activiteiten op het gebied van voorlichting over Nederland, culturele aspecten en publieke dienstverlening. De vestiging is verdeeld in twee werkgebieden: 1) Dienstverlening en 2) Kennisontwikkeling. De organisatie van het onderdeel Dienstverlening is hetzelfde als in China (één afdeling 'algemene zaken', waaronder de financiële administratie, onderhoud van de locatie en het archief vallen, en een afdeling 'klantcontacten', die de dagelijkse directe klantencontacten onderhoudt). Het onderdeel Kennisontwikkeling heeft drie kennisgebieden, die een grote mate van zelfstandigheid kennen. Op deze vestiging zijn 18 personen werkzaam, waaronder 10 uit Nederland uitgezonden en 8 lokale personeelsleden. De voertaal op deze vestiging is Nederlands, omdat nagenoeg alle lokale medewerkers van Nederlandse afkomst zijn of de Nederlandse taal beheersen. Slechts één medewerker is van oorsprong Engelstalig. Op het moment van onderzoek waren drie personen met vakantie en was één medewerker ziek. Ook bij deze vestiging wordt aan de inhoudelijke vraagstukken in nauwe samenwerking met het moederbedrijf in Nederland invulling gegeven. De Nederlandse medewerkers verblijven tussen de drie en vier jaar in Canada en de rest van het personeelsbestand kent een lange historie op deze vestiging. De arbeidsomstandigheden worden doorgaans als positief ervaren en de tevredenheid is hoog te noemen. Tijdens het onderzoek heeft de kennisorganisatie te maken met een aantal veranderingen op organisatorisch, beleidsmatig en personeelsmatig gebied:

- inkrimping van het personeelsbestand;

- het advies van de moederorganisatie om één centraal secretariaat in te richten;

- meer integratie en samenwerking tussen de diverse kennisgebieden;

- meer samenwerking met de andere vestigingen in Noord-Amerika;

- intensiveren van projectmatig werken;

- het sluiten van een andere vestiging in Canada, waardoor de hoeveelheid werk toeneemt.

Daarnaast bestaat bij het management de wens om meer resultaatgericht te werken, capaciteiten en talenten binnen de vestiging te mobiliseren en het afdelingoverstijgende denken c.q. werken te bevorderen.

\subsubsection{De opdracht}

Binnen de boven beschreven context wilde het management van de vestiging in eerste instantie een aantal wijzigingen in de organisatiestructuur realiseren door:

1. het inrichten van één centraal secretariaat dat alle afdelingen zou bedienen;

2. het inrichten van één unitbureau voor projecten dat alle afdelingen kan ondersteunen door de voorbereiding en uitvoering van speciale evenementen c.q. projecten op het gebied van organisatieoverkoepelende activiteiten; en

3. het invoeren van resultaatgericht c.q. projectmatig werken. 
Omdat deze veranderingen naar verwachting consequenties zouden hebben voor de bevoegdheden, verantwoordelijkheden en de organisatorische opzet van de vestiging, is externe hulp ingeroepen. Daarnaast was het management zich bewust dat behalve organisatorische/technische veranderingen ook op de gebieden van communicatie, samenwerking, houding en gedrag de nodige veranderingen doorgevoerd moesten worden. De beoogde verandering moest ook een positieve invloed hebben op de kwaliteit en het verbeteren van de efficiency van de organisatie.

\subsubsection{De aanpak}

Met het management van de Canadese vestiging zijn vóór de opdrachtverstrekking diverse gesprekken gevoerd. Daarbij is duidelijk geworden, dat in het begin een van hun aannames was, dat veranderingen binnen de organisaties vooral door de invoering van nieuwe procedures en structuren moesten worden gerealiseerd. In gesprekken met de onderzoekers en de personeelsdienst van de centrale organisatie in Nederland is duidelijk geworden, dat een dergelijke technische aanpak, in een kleine setting zoals die in Canada, niet tot de gewenste resultaten zou leiden, temeer omdat vanuit de centrale organisatie in Nederland een verdere inkrimping van het personeelsbestand op alle buitenlandse vestigingen is ingezet. Een gevolg daarvan zou zijn, dat afdelingen in Canada veelal uit één medewerker zouden bestaan. Bovendien wordt door de kleine setting nu al in multidisciplinaire (project)teams gewerkt. Het succes van een herinrichting is daardoor niet alleen afhankelijk van structuren en processen, maar ook van houding en gedrag in het dagelijkse werk en de bereidheid om meer samen te willen werken. Om goed uitvoering te kunnen geven aan deze veranderdoelstelling is door het management besloten, dat naast de organisatorische kant ook moest worden gewerkt aan vaardigheden, houding en gedrag van de medewerkers. Een ander argument van het management voor een meer gedragsmatige aanpak was, dat een groot deel van de lokale medewerkers relatief lang aan de organisatie verbonden is en de ingesleten gedragspatronen niet alleen door structuren kunnen worden veranderd. Uiteindelijk verschoof daarmee de opdracht van een meer op structuur gerichte aanpak naar een meer op verandermanagement gerichte aanpak. De wens was dat veranderingen tijdens het traject niet afgedwongen worden maar dat de actieve medewerking van alle betrokken medewerkers gestimuleerd wordt. Naast een advies ten aanzien van de organisatorische opzet die nodig is voor de voorgenomen verandering, had het management nu vooral behoefte aan advies en ondersteuning betreffende de fasering en begeleiding van een dergelijk veranderingsproces.

Gezien deze verwachtingen en door de ervaringen in China is vanuit de betrokken adviseurs aan het management geadviseerd om een aanpak te kiezen waarin de medewerkers voor een groot deel zelf participeren en betrokken worden. De vestiging zelf zou het eigen ontwikkeltraject vorm geven en uitvoeren. Om de verandering zoveel mogelijk te koppelen aan de dagelijkse werkzaamheden zijn vanuit de medewerkers 'trekkers' aangewezen, die medeverantwoordelijk zijn voor het traject, en daarin ondersteund worden vanuit de moederorganisatie in Nederland. Daarmee was gewaarborgd, dat de vragen die tijdens het traject zouden opkomen, adequaat beantwoord konden worden. Met het management is afgesproken is, dat de begeleiding uit een aantal begeleidingstrajecten ter plaatse (in Canada) zou bestaan en coaching op afstand. 
Tijdens de begeleiding op locatie zouden onder andere concepten, spelregels en vaardigheden geïntroduceerd worden, die het veranderproces vorm moeten geven en ondersteunen. Verder is afgesproken, dat tussen de twee interventies de adviseurs telefonisch contact zouden houden over het verloop van het proces. Ook zouden deze de rol van vraagbaak, klankbord en coach invullen. De vestiging zou zelf het tempo en de frequentie bepalen. Ter monitoring en evaluatie van dit traject is vanuit het management en de moederorganisatie nadrukkelijk verzocht om een meetinstrument in te zetten, dat, behalve voor een nulmeting, ook als (probleem)analyse-instrument ingezet wordt en dat de gerealiseerde voortgang meet.

Het definitieve traject bestond uit twee interventies (duur: één week) met een tussenperiode van tien maanden. Ook bij deze vestiging is IM in combinatie met de 'Reasoned Action Approach' toegepast. Conform de opgestelde uitgangspunten kwam bij de eerste interventie de nadruk te liggen op het concretiseren van de veranderdoelstelling, het opsporen van mogelijke bevorderende of belemmerende factoren en het benoemen van een toekomstbeeld over de vernieuwde organisatiestructuur. Bij de tweede interventie zou dan vervolgens aan de hand van meetresultaten onderzocht worden, wat de behaalde resultaten zijn, welke gebieden meer aandacht vragen en wat concrete verbetermaatregelen voor de toekomst zijn. Ten behoeve van de effectmeting is ervoor gekozen om voor de hoofdfactoren uit het 'Reasoned Action Model' ('attitude', 'ervaren norm', 'ervaren controle' en 'gedragsintentie') de eerder gebruikte (gevalideerde) vragenlijst als meetinstrument te gebruiken. De vragen betreffende de specifieke gedragsindicatoren zijn later, na de eerste intake, ingevuld. Globaal had het traject de volgende opzet (tabel 4.10). 
Tabel 4.10: Opzet van het programma

\begin{tabular}{|c|c|c|c|c|}
\hline In de week vooraf & Zaterdag / Zondag & Maandag & Dinsdag & Woensdag \\
\hline $\begin{array}{l}\text { Doornemen van } \\
\text { achtergrond- } \\
\text { informatie en } \\
\text { ontwikkelen van } \\
\text { het materiaal. }\end{array}$ & $\begin{array}{l}\text { - } \text { Vertrek uit NL. } \\
\text { - Kort overleg met de } \\
\text { opdrachtgever en } \\
\text { samen met het MT } \\
\text { vaststellen van het } \\
\text { definitieve pro- } \\
\text { gramma. }\end{array}$ & $\begin{array}{l}\text { Plenaire uitleg } \\
\text { voor het perso- } \\
\text { neel door de ver- } \\
\text { antwoor-delijke } \\
\text { vestigings- } \\
\text { manager. } \\
\text { - Formeren van } \\
\text { een stuurgroep } \\
\text { en start met Indi- } \\
\text { viduele gespre- } \\
\text { ken. } \\
\text { - Semigestructu- } \\
\text { reerd interview } \\
\text { waarin criteria en } \\
\text { uitkomst- } \\
\text { variabelen aan } \\
\text { bod komen. }\end{array}$ & $\begin{array}{l}\text { - Voortzetting } \\
\text { individuele inter- } \\
\text { views. } \\
\text { - } \text { Raamwerk voor } \\
\text { de veranderdoel- } \\
\text { stelling vastleg- } \\
\text { gen. } \\
\text { - Uitwerken van } \\
\text { een vragenlijst. } \\
\text { - Met de stuur- } \\
\text { groep de uit- } \\
\text { komstcriteria en } \\
\text { de vragenlijst } \\
\text { vaststellen. }\end{array}$ & $\begin{array}{l}\text { - Uitzetten van de } \\
\text { vragenlijst. } \\
\text { - } \text { Procesanalyse } \\
\text { uitvoeren. } \\
\text { Korte workshops } \\
\text { over projectmatig } \\
\text { werken, doelen } \\
\text { stellen, resultaat- } \\
\text { gericht werken. }\end{array}$ \\
\hline Donderdag & Vrijdag & Zaterdag / Zondag & \multicolumn{2}{|c|}{ Tussenliggend periode van max. 1 jaar } \\
\hline $\begin{array}{l}\text { Verwerking van } \\
\text { de vragenlijst en } \\
\text { alle andere gege- } \\
\text { vens. } \\
\text { - Analyse aan de } \\
\text { hand van litera- } \\
\text { tuurstudie over } \\
\text { kansen en be- } \\
\text { dreigingen. }\end{array}$ & $\begin{array}{l}\text { Voorbereiding van } \\
\text { de rapportage. } \\
\text { - Plenaire presentatie } \\
\text { van de uitkomsten. } \\
\text { - Uitwerken van een } \\
\text { veranderstrategie. }\end{array}$ & $\begin{array}{l}\text { - Uitwerken van de } \\
\text { gekozen oplos- } \\
\text { singsrichting met } \\
\text { MT. }\end{array}$ & \multicolumn{2}{|c|}{$\begin{array}{l}\text { - Implementeren van de veranderdoelstel- } \\
\text { lingen. } \\
\text { - Aanpassen structuren en processen. } \\
\text { - Monitoring van het proces door de stuur- } \\
\text { groep. } \\
\text { - Advies op afstand door experts. }\end{array}$} \\
\hline Voorbereiding & Zondag & Maandag & Dinsdag & Woensdag \\
\hline $\begin{array}{l}\text { - Voorbereiden } \\
\text { materiaal dat } \\
\text { door opdrachtge- } \\
\text { ver is opgegeven: } \\
\text { - Leiderschap } \\
\text { - Kennisdeling } \\
\text { - Verdieping } \\
\text { projectmatig } \\
\text { werken } \\
\text { - Teamwork / } \\
\text { Samenwerken }\end{array}$ & $\begin{array}{l}\text { - Aankomst en eerste } \\
\text { gesprekken met de } \\
\text { stuurgroep. } \\
\text { - Keuze van een } \\
\text { concreet en multi- } \\
\text { disciplinair project } \\
\text { in de toekomst. } \\
\text { - Definitief uitwerken } \\
\text { van het programma. }\end{array}$ & 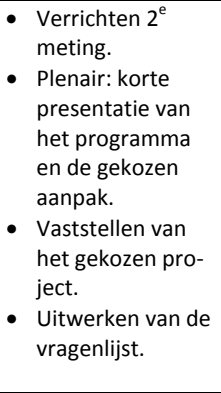 & $\begin{array}{l}\text { - Workshop } \\
\text { projectmatig } \\
\text { werken. } \\
\text { - Toepassen kennis } \\
\text { projectmatig } \\
\text { werken bij het } \\
\text { gekozen project. } \\
\text { - Workshop } \\
\text { samenwerken en } \\
\text { communicatie. } \\
\text { - Workshop voor } \\
\text { MT (leiding geven } \\
\text { aan projecten). }\end{array}$ & $\begin{array}{l}\text { Verder verdiepen } \\
\text { en uitwerken van } \\
\text { de geleerde ken- } \\
\text { nis in het gekozen } \\
\text { project. } \\
\text { - Presentatie van } \\
\text { de uitkomsten } \\
\text { van de vragenlijst. } \\
\text { Brainstorm } \\
\text { (plenair) over } \\
\text { mogelijke oplos- } \\
\text { sings-richtingen. }\end{array}$ \\
\hline Donderdag & Vrijdag & Zaterdag & & \\
\hline $\begin{array}{l}\text { Verdere uitwer- } \\
\text { king van het ge- } \\
\text { kozen project in } \\
\text { de diverse afde- } \\
\text { lingen. } \\
\text { - Workshop } \\
\text { kennisdeling. } \\
\text { - Overleg met } \\
\text { andere vestigin- } \\
\text { gen in Noord- } \\
\text { Amerika. } \\
\text { - Uitwerken van } \\
\text { het projectplan } \\
\text { en doelstellingen. }\end{array}$ & $\begin{array}{l}\text { Plenair bespreken } \\
\text { van het projectplan } \\
\text { en verdere uitwer- } \\
\text { king van verander- } \\
\text { doelstellingen }\end{array}$ & $\begin{array}{l}\text { Einde interventie } \\
\text { en terugreis. }\end{array}$ & & \\
\hline
\end{tabular}




\subsubsection{Uitvoering en meetmomenten}

Bij het onderzoek op de Canadese vestiging is nadrukkelijk gekozen om de principes van 'Intervention Mapping' te volgen, temeer omdat het management en de medewerkers van de vestiging zich ervan bewust waren, dat een eenmalige interventie zonder evaluatie en daaruit voortkomende verbeterpunten geen langdurig resultaat zou opleveren. Bij de eerste interventie stonden de probleemanalyse, het inzichtelijk maken van de uitkomstcriteria en het daarbij behorende gedrag, het exploreren van mogelijke oplossingsrichtingen en het opstellen van interventiestrategieën/plan centraal. Het interventieprogramma (in dit geval het concretiseren van projectmatig werken en het aanpassen van organisatiestructuren) is vooral door de medewerkers van de vestiging in Canada zelf uitgevoerd, waarbij de adviseurs op afstand ondersteuning hebben geboden. Deze bestond uit video conferencing, het opsturen van ondersteunend materiaal en het adviseren bij de aanpassing van de organisatiestructuren. Bij de tweede interventie lag de nadruk op het evalueren en verbeteren van de tot dat moment doorgevoerde veranderingen en het opstellen van een informatieplan. Als evaluatie-instrument is voor de reeds eerder gebruikte vragenlijst van de Chinese vestiging gekozen. Met behulp van een semigestructureerd interview zijn barrières en bevorderende factoren voor het slagen van een verandering op deze vestiging in kaart gebracht (zie kader 4.1).

Kader 4.1: Interviewvragen Canada

1. Wie ben je en wat doe je zoal?

2. Wat weet je van deze post?

3. Wat zijn jouw ideeën over projectmatig werken en resultaatgerichtheid?

4. Welke beelden heb je daarover?

5. Wat zijn je ervaringen?

6. Wat ware /zijn bevorderende of belemmerende factoren?

7. Welke thema's/onderwerpen zijn geëigend voor projectmatig/resultaatgericht werken?

8. Hoe past dit bij deze organisatie?

9. Wat heb je hiervoor nodig?

Bij het opstellen van de uitkomstcriteria is veel aandacht besteed aan het probleem van het gebruik van enkelvoudig gedrag en de beschrijving van gedragscategorieën (Fishbein \& Ajzen, 2010). Fishbein en Ajzen geven aan, dat het gebruik van gedragscategorieën mogelijk is, maar dat dan niet duidelijk is, welk specifiek gedrag in relatie staat tot een mogelijke interventie. Derhalve is in de stuurgroep uitvoerig bediscussieerd wat de gewenste uitkomst zou moeten zijn met betrekking tot 'actie', 'doel', 'context' en 'tijd'. Een punt dat hierbij een belangrijke rol speelde, was dat een te nauwe omschrijving van de uitkomstvariabelen talloze beschrijvingen van diverse gedragingen/handelingen zou opleveren waardoor de vragenlijst te uitgebreid wordt. Bovendien wordt daardoor bij een relatief kleine groep deelnemers de statistische verwerking en relevantie belemmerd. Anderzijds is ook duidelijk geworden, dat gedragscategorieën zoals 'projectmatig werken' of 'samenwerken' te weinig inzichtgeven in hetgeen men als organisatie wil bereiken. Uiteindelijk is gekozen voor algemene gedragscategorieën, die in een plenaire bijeenkomst nader zijn gespecificeerd en toegelicht. 
Het voordeel daarvan was, dat daarmee voor iedereen duidelijk is wat onder de gewenste gedragscategorieën verstaan wordt. Hierdoor bleef de omvang van de vragenlijst redelijk beperkt waardoor een snelle en eenvoudige verwerking mogelijk was.

Bij de eerste interventie waren $78 \%$ van alle medewerkers aanwezig $(N=14)$. Met iedereen is een individueel interview gehouden en de respons op de vragenlijst was bij de eerste meting $100 \%$. De vragenlijst zelf bestond naast een drietal algemene vragen (geslacht, leeftijd en opleiding) uit 30 onderzoeksvragen. 14 vragen hadden betrekking op de gewenste doelstelling en de 16 overige vragen hadden betrekking op de aspecten van het 'Reasoned Action Model' en zijn direct overgenomen uit eerdere onderzoeken. In tabel 4.11 zijn de gemiddelde scores van de hoofdfactoren weergegeven.

Tabel 4.11: Gemiddelde en Standaarddeviatie bij meting 1

\begin{tabular}{lrrr} 
& SD & $\begin{array}{r}\text { Gemiddelde } \\
\text { (range 1-6) }\end{array}$ & N \\
\hline Ervaren situatie Nu ('beliefs') & .98 & 4.45 & 14 \\
\hline Verwachting over de Toekomst ('beliefs') & .84 & 5.35 & 14 \\
\hline Attitude & .82 & 4.95 & 14 \\
\hline Ervaren Controle & 1.22 & 4.44 & 14 \\
\hline Ervaren Norm & .82 & 4.29 & 14 \\
\hline Intentie & .81 & 5.05 & 14 \\
\hline
\end{tabular}

Wat de uitkomsten van de eerste meting betreft, valt op te merken dat de scores op de antwoorden dicht bij elkaar liggen en dat er redelijk hoge scores worden ingevuld (gemiddelde van 4.8 bij een mogelijke score tussen de een en de zes en een standaarddeviatie van 0.9 ), een significante verandering en de ervaren 'verandernoodzaak' zouden hierdoor nadelig kunnen worden beïnvloed.

Wat de uitkomsten van de interviews en de vragenlijst van de eerste meting betreft gaven deze het volgende beeld:

- De veranderstrategie is in grote lijnen bekend, maar een koppeling met de werkzaamheden van ieder individu is niet aanwezig.

- De gekozen organisatiestructuur is voor iedereen inzichtelijk, maar verantwoordelijkheden zijn niet altijd even duidelijk.

- De randvoorwaarden om het werk te kunnen doen, zijn aanwezig.

- De medewerkers beschikken over voldoende ondersteunde systemen.

- Er is een 'wij-gevoel' aanwezig.

- Moeilijke dingen worden niet altijd duidelijk met elkaar besproken.

- Medewerkers hechten belang aan prioriteitstelling, duidelijke resultaten, zelf invloed kunnen uitoefenen op het werk en de samenwerking met anderen.

- Medewerkers missen een duidelijk plan, hebben het gevoel dat capaciteiten niet altijd even goed worden benut en missen de stimulans door hun leidinggevende.

Samen met de stuurgroep en het MT zijn de uitkomsten van de eerste meting besproken en zijn actiepunten voor de tussenliggende periode opgesteld, die verder naar een interventieprogramma moeten worden vertaald (zie kader 4.2). 
Kader 4.2: Aanbevelingen / Actiepunten

1. Maak duidelijk wat met de veranderdoelstelling wordt beoogd.

2. Stel prioriteiten in het werk (SMART) aan de hand van het jaarplan.

3. Stel een activiteitenplan per thema op.

4. Werk per afdeling één thema planmatig uit.

5. Richt geen centraal projectenbureau in.

6. Versterk ondersteuning waar mogelijk en gewenst.

7. Beleg taken waar ze logischerwijs thuishoren (bijvoorbeeld financieel).

8. Overleg per kwartaal over behaalde resultaten.

9. Ontwikkel visie en missie.

10. Inventariseer opleidingsbehoefte per medewerker en maak een ontwikkelplan.

11. Maak de rollen van het management duidelijker.

12. Praat niet over elkaar maar met elkaar (communicatie!)

In een plenaire bijeenkomst zijn de uitkomsten besproken en zijn oplossingsrichtingen voor de opgestelde aanbevelingen in kleine subgroepen geconcretiseerd. Ook hebben de adviseurs een procesanalyse doorgevoerd en zijn, samen met de stuurgroep, aan de hand van de uitkomsten van de vragenlijst en aan de hand van literatuuronderzoek 'best practices' uitgewerkt. ledere afdeling heeft aan de hand daarvan een eigen plan opgesteld, dat vervolgens met de andere afdelingen is afgestemd. In de resterende tijd hebben de adviseurs korte workshops gehouden met de thema's 'projectmatig werken', 'doelen stellen' en 'resultaatgericht werken'. Alle bevindingen zijn uiteindelijk in een plenaire bijeenkomst gepresenteerd en besproken. De uitkomst daarvan was een breed gedragen beeld over de bevindingen, waarin ook interne veranderdoelstellingen voor deze vestiging zijn meegenomen. ledere afdeling zou nu zelf een programma voor de komende zes maanden opstellen om de gewenste (verander)doelstellingen te behalen. De stuurgroep zou daarbij faciliteren en de regie op het gehele proces voeren. Met de betrokken adviseurs is afgesproken, dat er tussentijds contact zou worden onderhouden en mogelijke problemen of knelpunten regelmatig in een video conference besproken zouden worden. Na deze tussenliggende periode zouden de adviseurs opnieuw een meting op de vestiging doorvoeren, om aan de hand van de uitkomsten en de intussen opgedane ervaringen uit het project gerichte interventies te plegen.

De tweede interventie heeft uiteindelijk na tien maanden plaatsgevonden. In de contactmomenten die de adviseurs en de stuurgroep hebben onderhouden, is een aantal thema's verder uitgewerkt. Deze hadden betrekking op leiderschap, kennisdeling, projectmatig werken en samenwerken. Omdat in de beleving van de meeste medewerkers deze thema's invloed hebben op het dagelijkse werk, is de adviseurs nadrukkelijk gevraagd dit tijdens de tweede interventie aan bod te laten komen.

Direct na aankomst is een tweede meting met dezelfde vragenlijst verricht. Bij deze tweede meting waren $83 \%$ van alle medewerkers aanwezig $(N=15)$ en hebben daarvan 13 personen de vragenlijst ingevuld (een respons van $87 \%$ ). De opzet van deze tweede interventie was, dat na een aantal workshops de voortgang van de afgelopen tien maanden zou worden geëvalueerd en daar waar nodig opnieuw verbeterpunten zouden worden opgesteld. Het programma was redelijk identiek aan dat van de eerste interventie, waarbij nu de nadruk is gelegd op wat goed gaat en wat minder goed gaat en 
het proces erachter. In tabel 4.12 zijn de uitkomsten op de hoofdfactoren van de tweede meting weergegeven.

Wat opvalt zijn de relatief hoge scores op alle hoofdfactoren en de standaarddeviatie ten opzichte van de eerste meeting (zie tabel 4.11) is toegenomen. Dit duidt erop, dat de antwoorden van de deelnemers in de tweede meting meer van elkaar verschillen.

Tabel 4.12: Gemiddelde en Standaarddeviatie bij meting 2

\begin{tabular}{lrrr}
\hline & SD & $\begin{array}{r}\text { Gemiddelde } \\
\text { (range 1-6) }\end{array}$ & N \\
\hline Ervaren situatie Nu ('beliefs') & .81 & 5.29 & 13 \\
\hline Verwachting over de Toekomst ('beliefs') & 1.07 & 5.20 & 13 \\
\hline Attitude & .92 & 4.84 & 13 \\
\hline Ervaren Controle & 1.40 & 4.39 & 13 \\
\hline Ervaren Norm & 1.29 & 4.09 & 13 \\
\hline Intentie & 1.33 & 4.53 & 13 \\
\hline
\end{tabular}

Ter onderbouwing van de constructie van het meetinstrument is per schaal de Cronbach's $\alpha$ berekend. Deze varieerde van .51 tot .89 (zie tabel 4.14 ), wat voor de meeste schalen op een redelijke betrouwbaarheid duidt. Omdat de vragenlijst anoniem is verwerkt en de twee metingen niet naar een specifiek individu konden worden herleid, was een statistische analyse op individueel niveau niet mogelijk (gepaarde $t$-test). Derhalve zijn ook bij dit onderzoek de demografische gegevens van meting 1 en meeting 2 (leeftijd, opleiding en sekse) op verschillen onderzocht (zie tabel 4.13). De uitkomst laat zien, dat er geen significant verschil bestaat tussen de demografische kenmerken van de respondenten van meting 1 en meting 2 . Voor verder onderzoek naar de effecten en de ontwikkelingen kan daarom worden uitgegaan, dat de steekproef voor beide metingen met elkaar vergelijkbaar is.

Tabel 4.13: Analyse op de algemene gegevens tussen meting 1 en meting 2

\begin{tabular}{lcccccc}
\hline T-Test & $\boldsymbol{N}$ & Missing & $d f$ & $\boldsymbol{t}$ & $\boldsymbol{F}$ & $\boldsymbol{p}$-waarde \\
\hline Leeftijd & 21 & 6 & 20 &, 569 &, 033 &, 576 \\
\hline Chi-kwadraat toets & $\boldsymbol{N}$ & Missing & df & Pearson Chi-Kwadraat & Significantie \\
\hline Geslacht & 24 & 3 & 1 &, 686 &, 41 \\
\hline Opleiding & 25 & 2 & 3 &, 294 &, 96 \\
\hline (p<.05 = significant verschil) & & & & & \\
\hline
\end{tabular}

Daarbij moet wel worden opgemerkt, dat bij dergelijk kleine aantallen deelnemers statistische analyses uiterst onbetrouwbaar zijn. 


\subsubsection{Uitkomsten}

$\mathrm{Na}$ de eerste interventie was de vestiging in Canada zelf verantwoordelijk voor de verdere invulling van de gewenste doelstelling. Er is veelvuldig telefonisch contact geweest met de adviseurs en daarbij zijn knelpunten en problemen besproken. Ook hebben de adviseurs oplossingsrichtingen aangedragen, korte coachinginterventies doorgevoerd en met behulp van schriftelijke instructies tot meer zelfinzicht van de betrokken medewerkers bijgedragen. Na tien maanden is opnieuw een interventieprogramma opgesteld, waarin specifieke vragen van de vestiging Canada aan bod zijn gekomen. Diverse gesprekken, literatuuronderzoek en best practices uit andere vestigingen hebben het management en de stuurgroep ondersteund bij het vinden en benoemen van knelpunten in dit verandertraject. Het management was van mening, dat hun leiderschapsstijl effectiever kon worden ingezet. In overleg met de betrokken managers is een workshop ontwikkeld, waarin het thema 'leidinggeven aan professionals' (theorie van Kotter, 1996) en het managementmodel van Quinn (Quinn et al., 1994) verwerkt zijn. Kotter (1996) verwijst naar een achttal factoren, die van belang zijn bij de realisering van een veranderingsproces (zie kader 4.3). Deze grijpen op elkaar in en het is volgens Kotter (1996) van belang, dat men vanuit deze acht factoren regelmatig naar een veranderproject kijkt, analyses maakt en op basis daarvan nadenkt over mogelijke interventies.

De acht factoren zijn:

- urgentiebesef vestigen;

- de leidende coalitie zoeken;

- visie en strategie ontwikkelen;

- de veranderingsvisie communiceren;

- een breed draagvlak voor de verandering creëren;

- korte termijnsuccessen genereren;

- consolideren van de verandering; en

- de invloed van de organisatiecultuur.

Kader 4.3: Theorie van Kotter kort toegelicht

'Urgentiebesef' verwijst naar het bij de betrokken personen heersende gevoel, dat de gewenste verandering echt noodzakelijk is, dat deze urgent is, en noodzakelijk is om een veranderingsproject met succes te kunnen starten. Indien het gevoel van urgentie te weinig aanwezig is, zijn er bijna zeker te weinig personen te vinden om een verandering door te voeren.

Zelden kan één persoon een verandering in een organisatie helemaal alleen bewerkstelligen. Hoewel aan belangrijke veranderingen in organisaties vaak een naam verbonden is, is één persoon niet in staat alle functies te vervullen die nu eenmaal in een veranderingsproces essentieel zijn, zoals: de juiste visie ontwikkelen, deze voortdurend op alle niveaus naar grote aantallen mensen communiceren en obstakels uit de weg ruimen. Volgens Kotter (1996) is het belangrijk dat er een team ('leidende coalitie') wordt ingericht, waarin de goede personen zitten om de slaagkans van het veranderproject zo groot mogelijk te laten zijn. Zo'n team in de juiste samenstelling moet ook voldoende vertrouwen genieten in de organisatie. Dat team vormt idealiter de leidende coalitie. 
Bij veranderingsprocessen is ook een goede visie noodzakelijk om de algemene richting voor verandering aan te geven, mensen te motiveren tot het ondernemen van actie, individuele acties te bundelen en mensen op een lijn te brengen. Kotter geeft aan, dat, als mensen overtuigd zijn van een bepaalde visie, zij daar naar handelen. Daarmee is een goede visie veel effectiever dan het uitvaardigen van decreten of het minutieus voorschrijven hoe mensen de dingen moeten gaan doen.

Het vierde aandachtsgebied van Kotter (1996) legt de focus op een duidelijke communicatie. Om onzekerheid, angst en mogelijk wantrouwen te beperken, is het van belang, dat medewerkers weten waar ze aan toe zijn. Het gebruik van elke mogelijke manier om de nieuwe visie en strategieën te communiceren, staat daarbij voorop. De leden van de leidende coalitie moeten het goede voorbeeld geven aan de rest van de organisatie.

Volgens Kotter (1996) kan een nog zo goed plan niet werken als er onvoldoende draagvlak onder de betrokken personen is. Dit kan structureel van aard zijn, gebaseerd op een gebrek aan vaardigheden, systemen in de organisatie die tegenwerken, of gewoon slecht management.

De aanbeveling is deze factoren te identificeren, structureren en de systemen die de verandering verhinderen, aan te passen, mensen aan te moedigen in het nemen van risico's, alsmede het genereren van onconventionele ideeën en activiteiten.

Na de start van een veranderproces is het noodzakelijk op korte termijn successen te laten zien. In veel veranderprojecten staan verandering van visie en gedrag voorop. Veelal gaat dat gepaard met aanpassing van structuren en systemen in de organisatie. Bij ingrijpende veranderingen is het eindresultaat vaak pas na enkele jaren goed zichtbaar. Belangrijk voor het slagen van een dergelijk project is, dat er tussentijdse successen worden behaald, dat deze zichtbaar worden gemaakt, en een duidelijk verband hebben met het project. Na de eerste successen is Kotter(1996) van mening, dat het zaak is deze te consolideren en als opstapje naar nog meer successen te gebruiken.

Het is belangrijk om te achterhalen welke veranderingen tot de beoogde successen leiden. Ook is het aan te bevelen het tempo op te voeren, om de veranderingen op alle niveaus binnen de organisatie te bereiken.

Uiteindelijk leidt een veranderproces ook tot een andere cultuur. Cultuur heeft betrekking op de gedeelde waarden en gedragsnormen van een groep mensen. Gedeelde waarden representeren datgene wat mensen echt belangrijk vinden en als uitgangspunt en toetssteen voor hun handelen beschouwen. Gedragsnormen zijn impliciete of expliciete 'voorschriften' hoe de leden van de groep of organisatie zich behoren te gedragen.

Aan de hand van een werkboek gebaseerd op de theorie van Kotter (1996) heeft de stuurgroep een veranderplan opgesteld. Omdat men ook van mening was, dat het management een belangrijke rol speelt in dit proces is een analyse gemaakt gebaseerd op 
de managementrollen van Quinn $(1994 ; 2003)$. In kader 4.4 wordt het model kort toegelicht.

Kader 4.4: Managementmodel van Quinn kort toegelicht

Reeds Adizes (1981) heeft het werkterrein van de manager uitgewerkt naar vier aandachtsgebieden, die - afhankelijk van het niveau en de plaats waarop een manager in de organisatie functioneert - meer of minder aandacht vragen. Deze aandachtsgebieden zijn: Produceren, Beheren, Ondernemen en Integreren, en zijn uitgewerkt in het 'PBOI-model'. De essentie van het PBOI-denken is, dat elk van deze vier rollen in een managementfunctie moeten worden vervuld, alsmede dat minstens één rol uitstekend moet worden vervuld, wil er sprake zijn van adequaat management. Met andere woorden: wordt ook maar een van de rollen door een functionaris niet ingevuld, dan is er sprake van mismanagement.

Quinn (1994) heeft voortgeborduurd op het werk van Adizes en deze rollen uitgewerkt naar specifieke aandachtspunten en vaardigheden. Volgens Quinn bepalen deze in hoge mate, hoe effectief het management kan functioneren. Aan de hand van een 360-gradenfeedbacklijst zijn de managementrollen in kaart gebracht en is gezamenlijk afgesproken, wat daarvan de belemmerende en bevorderende aspecten zijn bij het beoogde veranderproces.

De stuurgroep was tevens van mening, dat het delen van kennis, projectmatig werken en samenwerken thema's zijn die tijdens de tweede interventie met iedereen besproken moesten worden (gebaseerd op Quinn \& Cameron, 1999). De adviseurs hebben in overleg met de stuurgroep enkele workshops ontwikkeld, waarin deze thema's aan bod zijn gekomen. Bovendien is ernaar gekeken, hoe met behulp van de digitale omgeving (het intranet) kennis binnen de vestiging en tussen de vestigingen in Noord-Amerika beter kan worden gedeeld. Bij de aankomst op de vestiging in Canada hebben de adviseurs samen met de stuurgroep het programma verder uitgewerkt. Daarbij is de nadruk gelegd op 'action learning' en is ervoor gekozen om aan de hand van een concreet multidisciplinair project de gewenste veranderdoelstellingen in de praktijk toe te passen. De stuurgroep en het management van de Canadese vestiging wilden er ook achter komen, wat het mechanisme van aanwezige barrières is. Direct daarna is de vragenlijst onder alle aanwezige medewerkers uitgezet en is de tweede meting verricht.

In grafiek 4.4 is een verandering ten aanzien van de factor die betrekking heeft op de huidige situatie ('belief nu') waar te nemen. Alle andere factoren laten een lichte, maar niet significante daling zien. Voor een goede statistische verwerking is Chronbach's- $\alpha$ voor de criteria van het 'Reasoned Action Model' berekend. Deze laat zien, dat er voldoende consistentie is op de onderzochte criteria. Om het verschil tussen meting 1 en 2 te onderzoeken is vervolgens gebruik gemaakt van een $t$-test en een ANOVA. De uitkomst (zie tabel 4.14) van de analyse laat zien, dat er slechts op het criterium betreffend de ervaren huidige situatie ('belief $N u^{\prime}$ ') een significant verschil kon worden aangetroffen. 


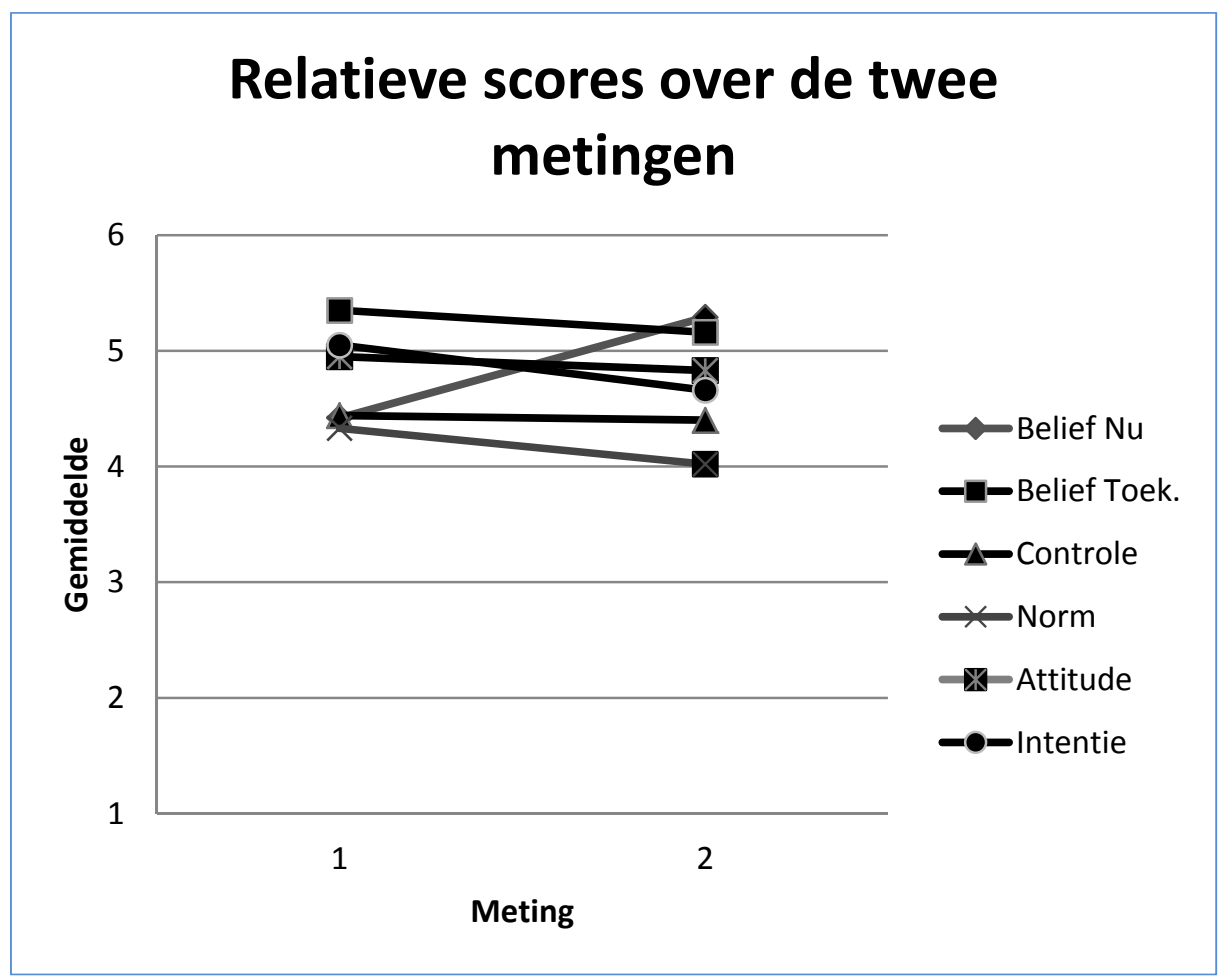

De uitkomsten zijn met de stuurgroep en het management besproken. Zelf gaven ze aan, dat de thema's 'samenwerking', 'werkprocessen' en 'geïnitieerde projecten' goed waren opgepakt. Problemen tijdens het traject zijn conform de eerdere aanpak geanalyseerd, om vervolgens verbeteringen door te kunnen voeren. Een analyse op itemniveau bevestigt het beeld, dat personen het gevoel hebben dat de huidige situatie in positieve zin is veranderd. In een plenaire bijeenkomst zijn de uitkomsten van de tweede meting en de bevindingen van de stuurgroep met alle medewerkers besproken. Een van de conclusies was dat men het belangrijk vond om prioriteiten te stellen, een duidelijke structuur neer te zetten en te weten welke resultaten van eenieder verwacht worden. Onduidelijk bleef de verwachting van iedereen ten opzichte van dit verandertraject, temeer omdat de uitkomsten van de twee metingen duidelijk aangaven, dat er een breed gedragen positief gevoel over de huidige situatie aanwezig was. In een dergelijke situatie rijst de vraag over wat en waarom er iets moet veranderen. Ook is duidelijk geworden, dat er een verschil in antwoorden bestaat tussen personen die zich meer dan anderen inzetten voor dit verandertraject (waaronder het topmanagement). Zij waren over het algemeen positiever. 
Globaal waren de betrokkenen doordrongen van de volgende uitkomsten:

- Medewerkers zijn positief over

- het stellen van prioriteiten

- een duidelijke structuur

- weten welke resultaten verwacht worden

- Minder positief zijn zij over

- de verwachting van anderen over het werken aan organisatieverandering

- de vraag of dat collega's daadwerkelijk aan organisatieverandering willen werken

- Duidelijke positieve verandering is aangetroffen over

- weten wat de prioriteiten zijn in het werk

- zelf een bijdrage kunnen leveren aan de beoogde verandering

- zelf binnen één jaar aan de beoogde verandering gewerkt hebben

Voor betrokken medewerkers is duidelijk wat de prioriteiten zijn en welke resultaten van eenieder verwacht worden. Ook wordt de gekozen organisatiestructuur als helder en functioneel ervaren. Betrokken medewerkers zijn erbvan doordrongen, dat een verandering afhangt van hun eigen inzet, en zij zijn bereid zich verder in te zetten voor de gekozen veranderdoelen. Een aandachtspunt blijft de 'aanjagersrol', waardoor voor betrokkenen duidelijk wordt wat er verwacht wordt. Uiteindelijk is geconcludeerd, dat er nog steeds een positief klimaat voor de ingeslagen koers op de vestiging aanwezig is. Weliswaar maakt de standaarddeviatie tussen de antwoorden duidelijk dat er nog verschillen zijn tussen de individuele medewerkers, maar statistisch gezien is dat niet van invloed op de uitkomsten. ledereen acht de ondersteuning door het management een belangrijke factor voor het succes en er blijft ook in de toekomst een meer gestructureerde aanpak om knelpunten aan te pakken noodzakelijk. Met deze uitkomsten zijn op de verschillende afdelingen/projectteams veranderdoelstellingen geformuleerd. Het gehele traject is door alle deelnemers als positief ervaren.

Ook in dit deelonderzoek leek de op basis van de 'Reasoned Action Approach' ontwikkelde vragenlijst en de op de principes van IM gebaseerde aanpak een goed instrument om de beoogde (gedrags)verandering te meten. Ook hierbij diende de eerder ontwikkelde vragenlijst als feedbackinstrument en had daarmee twee doelen: het meten van de beoogde verandering en de deelnemers inzicht geven in de bevorderende en belemmerende factoren. Daarnaast bood ook hierbij de gekozen methode inzicht in de factoren die van invloed zijn op het resultaat. Vooral de terugkoppeling aan de deelnemers en het betrekken van hun inzichten/ervaringen bij het proces bleken een waardevolle interventie. Echter ook bij dit onderzoek was de groepsomvang erg klein en is door het onderzoeksteam ervan uitgegaan, dat de eerder ontwikkelde vragenlijst valide en betrouwbaar is. Een aanname die strikt genomen niet goed kan worden volgehouden. In de discussie zal hierop verder worden ingegaan. Resumerend suggereren de uitkomsten dat de deelvragen 1 tot en met 4 uit eerder onderzoek positief beantwoord kunnen worden. 
Tabel 4.14: Uitkomstcriteria / Gedragsaspecten

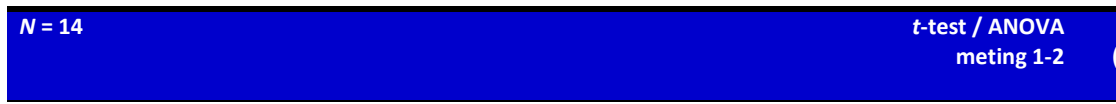

Gemiddelde

ange $=1-6$ )

Huidige situatie (Belief $\mathrm{Nu}$ )

Huidige situatie (Belief Nu)

We show teamwork (never - always)

I know what the priorities are in my work (never - always)

Clear structure is present in my work (never - always)

I know what results are expected from my work (never - always)

$5.21 / 5.54$

In my work I appeal to a person's capacity of other sections (never

$4.50 / 5.08$

I work with a set plan (never - always)

I have a grip on the circumstances which influence my work (never - always)

For me to develop teamwork on this post during the next years is (unim-

For me to know what the priorities are in my work is (important unimportant)

To have clear structure in my work is (unimportant - important)

For me to know what results are expected from my work is (unimportant -

important)

For me to appeal to a person's capacity of other sections is (unimportant -

important)

For me to work with a set plan is (unimportant - important)

$4.86 / 5.08$

To have a grip on the circumstances which influence my work is (unim-

$5.36 / 4.91$ portant - important)

${ }^{*}=$ significant verschil $p<.05,{ }^{* *}=$ significant verschil $p<.015 .36$

\begin{tabular}{|c|c|c|}
\hline Vragen over de criteria van het 'Reasoned Action Model' & $\begin{array}{rr}\text { Cronbach's } \alpha & t \text {-test / ANOVA } \\
(N=14) & \text { meting } 1-2\end{array}$ & $\begin{array}{r}\text { Gemiddelde } \\
\text { (Range }=1-6 \text { ) } \\
\text { Meting } 1 / 2\end{array}$ \\
\hline ATTITUDE & $\alpha=0.89$ & $4.95 / 4.83$ \\
\hline For me to work on organizational development has direct & .80 & $S D$ \\
\hline influence on my performance (negative - positive) & & $0.70 / 0.86$ \\
\hline $\begin{array}{l}\text { I find working on organizational development (worthless - } \\
\text { valuable) }\end{array}$ & .88 & \\
\hline $\begin{array}{l}\text { For me to work on organizational development is (unpleasant - } \\
\text { pleasant) }\end{array}$ & .82 & \\
\hline $\begin{array}{l}\text { To work on organizational development during the next } 6 \\
\text { month will be (worthless - valuable) }\end{array}$ & .85 & \\
\hline ERVAREN CONTROLE (Controle) & $\alpha=0.51$ & $4.44 / 4.39$ \\
\hline For me to work on organizational development (difficult - easy) & .50 & $S D$ \\
\hline $\begin{array}{l}\text { It's up to me whether I will put effort in organizational devel- } \\
\text { opment (disagree - agree) }\end{array}$ & .48 & $0.80 / 0.69$ \\
\hline $\begin{array}{l}\text { There are possibilities for me to work on organizational devel- } \\
\text { opment (none - many) }\end{array}$ & .51 & \\
\hline $\begin{array}{l}\text { The means to contribute on organizational development are } \\
\text { (none-many) }\end{array}$ & .49 & \\
\hline
\end{tabular}




\begin{tabular}{|c|c|c|}
\hline ERVAREN NORM(Norm) & $\alpha=0.72$ & $4.33 / 4.02$ \\
\hline $\begin{array}{l}\text { Most colleagues are supportive when I bring up organizational } \\
\text { issues (never - always) }\end{array}$ & .71 & $S D$ \\
\hline $\begin{array}{l}\text { My direct supervisor stimulates me in working on organiza- } \\
\text { tional development (false - true) }\end{array}$ & .70 & $0.44 / 0.71$ \\
\hline $\begin{array}{l}\text { Others expect me to work on organizational development } \\
\text { (false - true) }\end{array}$ & .69 & \\
\hline $\begin{array}{l}\text { Most of the members of this organization want to work on a } \\
\text { better organization (none - many) }\end{array}$ & .63 & \\
\hline INTENTIE & $\alpha=0.78$ & $5.05 / 4.67$ \\
\hline $\begin{array}{l}\text { That I will put effort in organizational development is (unlikely } \\
\text { - likely) }\end{array}$ & .77 & $S D$ \\
\hline $\begin{array}{l}\text { I am confident that I will work on organizational development } \\
\text { (false - true) }\end{array}$ & .73 & $0.62 / 0.78$ \\
\hline $\begin{array}{l}\text { Next year I will have worked on organizational development } \\
\text { (I will not - I will) }\end{array}$ & .76 & \\
\hline $\begin{array}{l}\text { I intent to work on organizational development during the next } \\
6 \text { month (disagree - agree) }\end{array}$ & .64 & \\
\hline
\end{tabular}

\subsection{Resumé van de drie casestudies}

Bij de in dit hoofdstuk beschreven drie casestudies is het eerder ontwikkelde meetinstrument volgens de principes van 'Intervention Mapping' in de praktijk toegepast. Ondanks dat organisaties en vraagstukken van elkaar verschillen, kan een aantal voorlopige conclusies geformuleerd worden. Ten eerste is er veel inzicht verworven over de praktische toepassing van het ontwikkelde meetinstrument. In de praktijk is de ontwikkeling en toepasbaarheid van het meetinstrument, ook na vertaling, uitermate praktisch gebleken. Door het werken met tegenstellingen op een 6-puntsschaal moeten de deelnemers een keuze maken en kan de uitkomst kwalitatief op gemiddelde en standaarddeviatie eenvoudig aan de deelnemers gepresenteerd worden. De vragenlijst is relatief kort, het vergt weinig tijd deze in te vullen en te verwerken. Ook de schaalconstructie (Cronbach's $\alpha$ ) bleek in de meeste gevallen voldoende valide. Het formuleren van de uitkomstcriteria (het beoogde gedrag) en het opsporen van barrières en bevorderende factoren leek meer tijd te kosten dan verwacht. Vooral door de toepassing van semigestructureerde interviews en het werken met een expertgroep maken het proces arbeidsintensief. Echter, het voordeel daarvan was, dat voor iedereen de beoogde verandering zeer concreet is geworden en dat iedereen meer bewust is van wat nu precies de doelstelling is. Deze uitkomsten bevestigen in voorzichtige mate deelvraag 1 en 2. Het grootste probleem bleek toetsing van de validiteit van het instrumentarium. Strikt genomen had bij alle onderzoeken op z'n minst de expertvaliditeit en testhertestbetrouwbaarheid onderzocht kunnen worden. Door het ontbreken van een expertgroep ter plaatse en de tijdsdruk was dat niet mogelijk.

De ontwikkeling van het definitieve meetinstrument per onderzoek bleek al een interventie bij de beoogde verandering. De deelnemers werden betrokken bij de ontwikkeling van een eigen leertraject en diffuse of vage doelstellingen zijn geconcretiseerd. Door het concretiseren van de in de 'Reasoned Action Approach' beschreven factoren is zowel de deelnemers als de verantwoordelijke functionarissen bewust geworden wat men daadwerkelijk in de toekomst zou willen veranderen en welke belemmerende en bevorderende factoren daarbij een rol spelen. Ook is gedrag hierdoor bespreekbaar geworden en dit maakt de boogde verandering in de praktijk tastbaarder. Hierdoor 
wordt het wel minder duidelijk of de toegepaste interventies ook voor een groot deel de uitkomsten hebben beïnvloed of dat mogelijke effecten kunnen worden toegeschreven aan het gebruik van de vragenlijst. Ondanks alle belemmeringen kunnen deelvraag 3 en 4 positief worden beantwoord. Wat de effectiviteit betreft, heeft zich het meetinstrument in de toepassing als zodanig bewezen en gaven de uitkomsten in voldoende mate inzicht in het behaalde resultaat.

Een ander opmerkelijke waarneming uit de deelonderzoeken is de invloed van een aanjager (en dan vooral het management) op de uitkomst van een beoogde verandering. Weliswaar kan geen direct causaal verband worden aangetroffen voor deze relatie en was het geen directe onderzoeksvraag van dit proefschrift. Opmerkelijk blijft het wel, dat in alle gevallen de start- en de follow-upmeting afhankelijk waren van de initiator van een dergelijk traject. In de visie van Kotter (1996) speelt de leidende coalitie kennelijk een belangrijke rol bij verandertrajecten. Dit wordt in alle gevallen geïllustreerd door het wegvallen van een tweede nameting als gevolg van het vertrek van het management, wellicht een aanname die verder zou kunnen worden onderzocht.

Met betrekking tot het concretiseren van het beoogde gedrag, blijft het moeilijk dat in de termen van 'actie', 'richting', 'context' en 'tijd' zo eenduidig mogelijk te omschrijven. Weliswaar is dat opgelost door iedere deelnemer bij de definitie c.q. de beschrijving van het gedrag te betrekken, maar desondanks blijft de kans op interpretatie van de uiteindelijke uitkomst groot. De toepassing van de principes van 'Intervention Mapping' bleek uitermate praktisch en ondersteunend in het proces. Niet alleen wordt de onderzoeker en de betrokkenen vooraf een stappenplan gegeven dat gemakkelijk te volgen is, ook kunnen de interventies goed met elkaar worden vergeleken. Het dwingt de betrokken personen het vraagstuk of probleem op een systematische manier te benaderen, zonder dat van tevoren wordt opgelegd hoe het probleem kan worden opgelost. Tevens legt 'Intervention Mapping' een groot deel van de verantwoordelijkheid voor de gekozen oplossingsrichting duidelijk bij de probleemeigenaar en bevordert hierdoor de herkenbaarheid en betrokkenheid. Het maakt duidelijk dat gedragsverandering geen eenmalige gebeurtenis is, maar een proces dat steeds kan worden verbeterd. Hierop gaathoofdstuk 6, 'Conclusie en discussies', dieper in.

Deelvraag 5 - hoe kunnen interventies op het gebied van gedragsverandering goed met elkaar worden vergeleken? - kan minder eenduidig worden beantwoord. Een voorzichtige conclusie die uit de onderzoeken kan worden getrokken, is dat de factor 'ervaren controle' het meest significant aan verandering onderhevig is; een onderbouwing van de door Fishbein en Ajzen (2010) gelegde relatie tussen de factoren 'ervaren controle' en 'intentie', maar ook met het 'uiteindelijke gedrag'. Door deelnemers terugkoppeling te geven op belemmerende en bevorderende factoren zou dit effect mogelijk nog versterkt worden.

In de uitgevoerde onderzoeken is duidelijk geworden, dat effecten van (gedrags)interventies in het veld vanuit statistisch oogpunt weinig waarde hebben, omdat naast meerdere meetmomenten ook een controlegroep ontbreekt. Tevens is het geringe aantal deelnemers binnen de interventiegroep een grote belemmering voor gedegen statistische analyses. Het wordt minder duidelijk of veranderingen toe te schrijven zijn aan de interventie, situationele invloeden of toevalligheden. In de voorbeelden vond óf de opdrachtgever het niet wenselijk om een deel van de medewerkers bij de verandering te betrekken (casestudie 1) óf was de groepsomvang dermate klein, dat de keuze 
voor het werken met een controlegroep niet verantwoord was. Omdat in de praktijk ook niet zo snel zal worden gekozen voor een systematisch onderzoek met meerdere interventie- en controlegroepen, is dat ook niet verwonderlijk. Een dergelijke aanpak is wellicht in hele grote organisaties mogelijk, waarbij sprake is van een gestandaardiseerd en uniform trainingsaanbod. Voor de verdere toepassing van dit instrument is het van belang een methode te ontwikkelen, waarbij het gebruik van een controlegroep niet noodzakelijk is (maar statistisch verantwoord blijft). Het volgende hoofdstuk zal hierop verder ingaan. 


\section{$5 \quad$ Verantwoorde effectmeting zonder controlegroep ${ }^{2}$}

\subsection{Inleiding}

In het vorige hoofdstuk is duidelijk geworden, dat een statistisch verantwoorde analyse bij onderzoeken in het veld met relatief kleine groepen erg lastig is. Naast de groepsomvang, het bepalen van de betrouwbaarheid en de validiteit van de te onderzoeken factoren is ook het ontbreken van een controleroep een gegeven, dat uit wetenschappelijk oogpunt onwenselijk is. Voor de ontwikkeling van het meetinstrumentarium van dit proefschrift is dan ook gebruik gemaakt van een interventie-controlegroepdesign om de effectiviteit van de op de 'Reasoned Action Approach' gebaseerde vragenlijst en de toepassing van de principes van 'Intervention Mapping' te toetsen. Een dergelijke aanpak wordt in de regel als ideaal gezien (Baarda, \& de Goede, 2001; Mathieu et al., 1993; Wang, 2006), omdat de uitkomsten van de interventiegroep (die deelneemt aan de interventie of training) direct kan worden vergeleken met die van een controlegroep (die niet deelneemt). Als deze groepen vóór de interventie vergelijkbaar scoren op het te beïnvloeden concept en er ná de interventie een statistisch betekenisvol verschil wordt gevonden, kan worden geconcludeerd, dat de interventie effectief is geweest. Bij de toepassing van het ontwikkelde proces en de daarbij behorende vragenlijst (de drie casestudies) kon helaas geen gebruik worden gemaakt van een controlegroep. In het voorbeeld van de kennisorganisatie in Canada (casestudie 3) lag de oorzaak aan het klein aantal deelnemers. Vanuit de samenstelling van functies, demografische gegevens en werkterrein was het niet mogelijk twee vergelijkbare groepen in te richten. Bij het productiebedrijf in Nederland was het vooral vanuit organisatiebelang niet mogelijk de groep in tweeën te splitsen. Het management wilde binnen een specifieke termijn de gedragsverandering bij alle medewerkers hebben doorgevoerd en het was door wisselende diensten/roosters niet mogelijk vaste groepen te selecteren. In alle gevallen bleek het een onmogelijke taak een vergelijkbare controlegroep samen te stellen, omdat de specifieke omstandigheden (land, cultuur, werkinhoud, e.d.) te bijzonder zijn (zoals bijvoorbeeld de kennisorganisatie in China) en werkterreinen door één enkele persoon bemenst waren. Het aangetroffen probleem is reeds eerder beschreven (RussEft \& Preskill, 2005; Salas \& Cannon-Bowers, 2001) en terecht constateren Wang en Wilcox (2006) dat bij gedragsinterventie in het veld vaak geen controlegroep beschikbaar is.

Een controlegroep is idealiter qua aantal deelnemers, samenstelling, leeftijdsopbouw en omstandigheden identiek aan de interventiegroep. Vanuit het oogpunt van de opdrachtgever is het gebruik van een controlegroep moeilijk te realiseren. Ook is het werken met controlegroepen bij een gedragsinterventie voor veel organisatie een te kostbare zaak. In het vorige hoofdstuk, waarin drie casestudies gepresenteerd werden, is bovendien duidelijk geworden, dat veel interventies ook voor een specifieke situatie ontwikkeld zijn en het statistisch en ethisch niet verantwoord is om een deel van de groep niet te laten deelnemen aan een training of interventie. Binnen organisaties zou dat namelijk betekenen, dat de helft van de in aanmerking komende medewerkers bewust wordt uitgesloten. Daarnaast moeten er vanuit statistische overwegingen dan nog voldoende deelnemers overblijven voor de interventiegroep. Ook zal men bij een der-

Dit hoofdstuk is voor een groot deel gebaseerd op het artikel Rauner, M., Groot, de S., Kok, G. \& Taris, T. (2009): Betrouwbare Effectmeting zonder Controlegroep. Opleiding \& Ontwikkeling, 22, 15-18. 
gelijke aanpak vaak bezwaar hebben tegen het onvrijwillig uitsluiten van de helft van de in aanmerking komende medewerkers. Een ander aandachtspunt is, dat bij gedragsinterventies (zoals trainingen) in veel gevallen voor slechts één evaluatiemoment gekozen wordt, namelijk na de interventie, waardoor een duidelijke uitspraak over de effectiviteit van de interventie niet mogelijk is. In situaties waarbij wel gebruik kan worden gemaakt van een voor- en nameting, is het door de kleine groepsomvang vaak moeilijk om een statistisch significant verschil door middel van een controlegroep aan te tonen.

Vanuit wetenschappelijk oogpunt blijft het voor het bepalen van effecten wenselijk de scores van een interventiegroep te kunnen vergelijken met die van een controlegroep en te werken met een voor- en nameting. Hier ontstaat dus een dilemma dat moeilijk op te lossen is en men zou kunnen concluderen, dat onderzoek met een controlegroep alleen bij grote organisaties uitvoerbaar is, zoals dat bij de ontwikkeling van het voor dit onderzoek ontwikkelde meetinstrument heeft plaatsgevonden. Voor de verdere toepassing van het meetinstrumentarium is het dan ook wenselijk om gebruik te kunnen maken van een vragenlijst die wel voldoende inzicht geeft in het effect van een interventie zonder dat er nadrukkelijk gebruik hoeft te worden gemaakt van een controlegroep. Hierdoor wordt een van de eerder geformuleerde doelstellingen gerealiseerd, namelijk om een eenvoudig, niet tijdrovend, gemakkelijk te verwerken en zoveel mogelijk gestandaardiseerd meetinstrument te ontwikkelen. Voor de verdere toepassing van het ontwikkelde proces en meetinstrumentatrium in de praktijk is het dan ook wenselijk een oplossing te vinden om verantwoord onderzoek te kunnen verrichten zonder het gebruik van een controlegroep.

Gebaseerd op de uitkomsten eerdere onderzoeken biedt de zogenoemde 'Internal Referencing Strategy' (IRS, Garson, 2008; Haccoun \& Hamtieux, 1994) ook wel bekend als het 'Non Equivalent Dependent Variable Design' (Cook \& Campbell, 1979) een oplossing voor dit probleem. Met de IRS worden de effecten van een training of interventie vergeleken met gedragsaspecten die juist niet zouden moeten worden beïnvloed. Beide effecten worden bij dezelfde groep gemeten, zowel vóór aanvang van de training als na afloop ervan. Verondersteld wordt, dat de deelnemers een verandering zullen laten zien in het gedrag dat door de training beïnvloed zou moeten worden, in vergelijking tot gedragsaspecten die geen verband daarmee houden (idealiter veranderen de scores in het laatste geval niet). In dat geval kan er aangenomen worden, dat de training effect had, zonder dat er een controlegroep wordt ingezet. Voor toekomstig onderzoek zou dat betekenen, dat het gebruik van een controlegroep niet per se noodzakelijk is en dat het hiervoor ontwikkelde meetinstrumentarium voldoende geschikt is om effecten van interventies te kunnen meten. Vooral bij vraagstukken waarbij specifieke doelgroepen of organisatieonderdelen betrokken zijn en de groepsomvang een controlegroep niet toelaat, lijkt IRS een goede oplossing. Daarnaast zou het ook vanuit bedrijfseconomisch gezichtspunt een verantwoorde keuze zijn. 


\subsection{De onderzoeksmethode}

De aanname van dit deelonderzoek is, dat IRS een betrouwbare methode is om zonder controlegroep een effectstudie uit te kunnen voeren en dat de eerder ontwikkelde vragenlijst gebaseerd op de 'Reasoned Action Approach' voldoende statistische kracht heeft om effecten bij gedragsinterventie te kunnen meten. Dit deelonderzoek is uitgevoerd bij een in-company training voor start-, functionerings- en beoordelingsgesprekken (SFB) van een overheidsorganisatie met 4.000 medewerkers. De training wordt meerdere malen in een jaar gegeven. Vanuit de P\&O-afdeling was de vraag om een instrument te ontwikkelen, dat het effect van trainingen bepaalt en dat inzicht geeft in de invloed van de trainingen op de door de organisatie gestelde doelstellingen. De opzet en aanpak van het onderzoek waren vergelijkbaar met die van het eerdere onderzoek ten behoeve van de ontwikkeling van het onderzoekinstrumentarium. Daarbij is de doelgroep verdeeld in een experimentele groep (die de training volgt) en een controlegroep die geen training volgt. Bij het samenstellen van de experimentele groep en de controlegroep is uit alle aanmeldingen voor de training een selectie gemaakt van een groep managers die direct konden deelnemen aan de training en een groep managers die later in het jaar de opleiding zouden volgen en daarmee de controlegroep vormden (figuur 5.1).

Figuur 5.1: Selectie van de onderzoeksgroepen

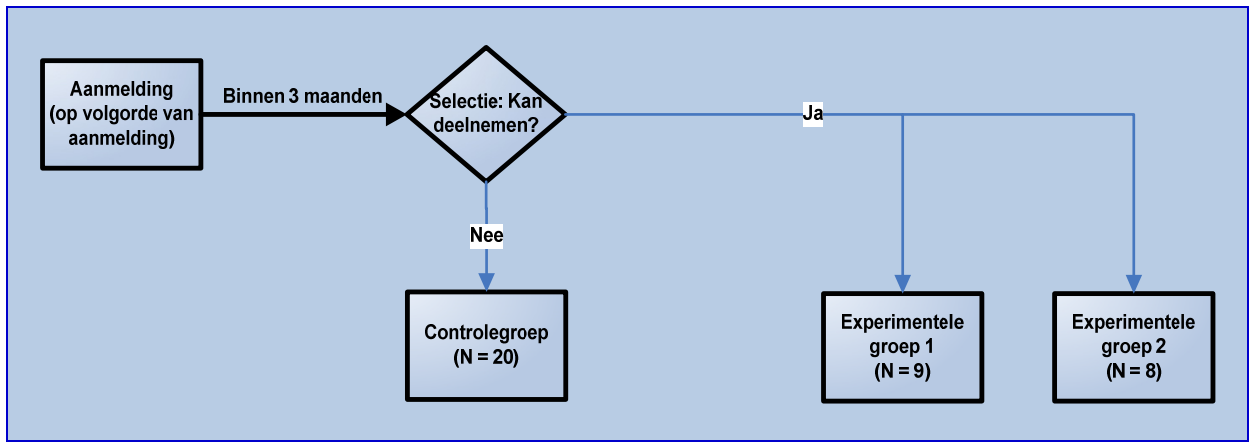

Voor de praktische toepassing is gebruik gemaakt van de eerder ontwikkelde vragenlijst gebaseerd op de 'Reasoned Action Approach', aangevuld met onderzoeksvragen van de IRS. Het betreft daarbij gedragsaspecten die weinig te maken hebben met de doelstelling van de training. Hiervoor is de vragenlijst specifiek inhoudelijk aangepast en is ook een onderzoeksproces conform de principes van de 'Intervention Mapping'-methode in een gestructureerd programma uitgewerkt.

De vragenlijst bestond deels uit de eerder gevalideerde vragenlijsten en deels uit irrelevante vragen met betrekking tot de doelstelling van de training. De aanname was dat de experimentele groep een grotere groei op de relevante vragen en de vragen gericht op de gewenste gedragsverandering zou laten zien dan op de irrelevante vragen. Bij de controlegroep was de aanname, dat de scores gelijk zouden blijven. In dat geval kon er gesproken worden van effect van de training op de deelnemer (Garson, 2008). 
Uiteindelijk is de vragenlijst twee keer afgenomen in een periode van drie weken. Beide groepen kregen dezelfde onderzoeksvragen voorgelegd. Voor de controlegroep werd dezelfde tussenperiode aangehouden als de duur van de training (twee dagen). In de tussentijd ontving de interventiegroep $(N=15)$ de training; de controlegroep $(N=17)$ werd niet getraind. De vragenlijst werd door zowel de experimentele als de controlegroep op dezelfde dagen voor en na de training ingevuld (zie figuur 5.2). De gekozen onderzoeksopzet laat zich schematisch als volgt weergeven:

Figuur 5.2: Schematische weergave van de onderzoeksopzet

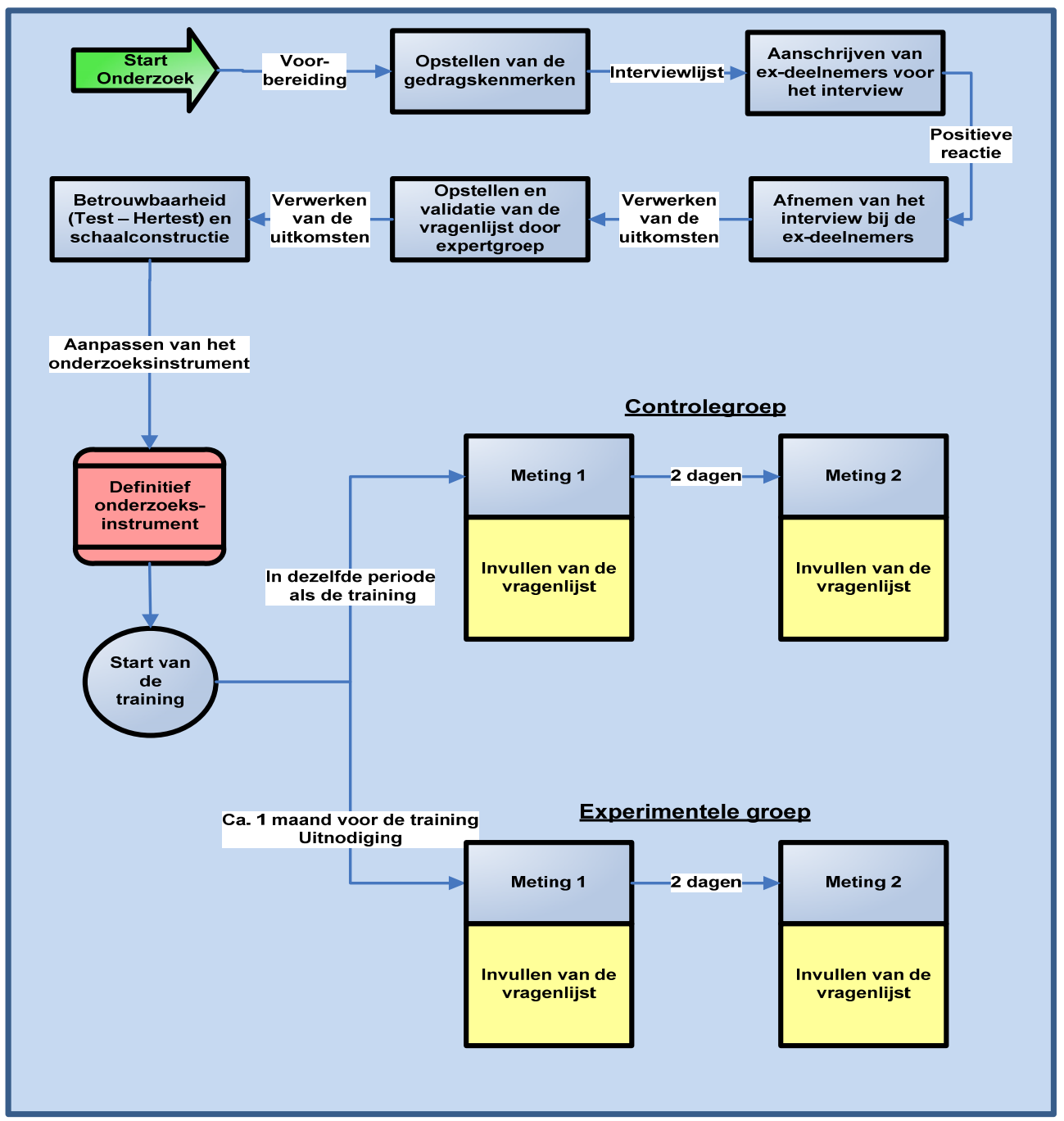

Naast een uitspraak over het effect van de training kon er aan de hand van deze aanpak ook een uitspraak worden gedaan over de bruikbaarheid van de 'Internal Referencing Strategy' (IRS). Wanneer de resultaten daadwerkelijk zouden uitwijzen, dat er een 
verschil was tussen de relevante en irrelevante items bij de experimentele groep, terwijl dat bij de controlegroep niet het geval was, zou in de toekomst ook van deze vragenlijst gebruik kunnen worden gemaakt zonder toepassing van een controlegroep.

De training (SFB) bestond uit een voorbereidingsopdracht en een bijeenkomst van twee aaneengesloten dagen. Voor de training zijn door de organisatie drie hoofddoelen geformuleerd:

- betere vaardigheden in het voeren van start-, functionerings- en beoordelingsgesprekken door het maken van SMART-afspraken en het meedenken over de wensen van de medewerker;

- het kennen van regels en procedures en het toepassen van de checklijsten die de organisatie aanbiedt c.q. voorschrijft; en

- het zorgvuldig kunnen oordelen en rekening houden met de eigen kwaliteiten en valkuilen in het beoordelen.

Voor alle experimentele groepen was de opzet en het materiaal van de training uniform van aard. Tevens is er met een draaiboek en steeds met dezelfde trainer gewerkt. Voor de training is de volgende opbouw gehanteerd (tabel 5.1):

Tabel 5.1: Opzet van de training 'Start-, Functionerings- en Beoordelingsgesprekken'

\begin{tabular}{|c|c|c|}
\hline Onderdeel & Inhoud & Doelstelling \\
\hline $\begin{array}{l}2 \text { dagen aaneengesloten op een } \\
\text { externe locatie }\end{array}$ & $\begin{array}{l}\text { - Kennismaking } \\
\text { - Kennisoverdracht SFB ge- } \\
\text { - } \text { sprekken } \\
\text { - } \text { SMmmunicatie: basisfuncties } \\
\text { - Oefenen met Startgesprek } \\
\text { - } \text { Leidinggevende als coach } \\
\text { - Geven van feedback } \\
\text { - Vraagtechnieken } \\
\text { - Oefenen met Functionerings- } \\
\text { - } \text { gesprek } \\
\text { - } \text { Omgaan met weerstand } \\
\text { - Oefenen van slecht nieuws } \\
\text { - } \text { gesprek } \\
\text { Eigen leerdoelen opstellen }\end{array}$ & $\begin{array}{l}\text { - Vaardig in het voeren van } \\
\text { Start-, Functionerings- en Be- } \\
\text { oordelingsgesprekken } \\
\text { - SMART maken van afspraken } \\
\text { en het meedenken over de } \\
\text { wensen van de medewerker } \\
\text { - Het kennen van regels en } \\
\text { procedures en subdoelen van } \\
\text { de organisatie } \\
\text { - Rekening houden met kwali- } \\
\text { teiten en valkuilen in het pro- } \\
\text { ces } \\
\text { Omgaan met weerstand }\end{array}$ \\
\hline
\end{tabular}

Voor dit deelonderzoek is de oorspronkelijk ontwikkelde vragenlijst gebaseerd op de 'Reasoned Action Approach' verkleind (compacter gemaakt) en zijn, conform de IRS, uitkomstvariabelen die gericht waren op de leerdoelen van de training en irrelevante variabelen, toegevoegd. Om te voorkomen dat deze irrelevante vragen te gemakkelijk zouden worden herkend, is aan de constructie van de betreffende schaal extra aandacht geschonken. Uiteindelijk is ervoor gekozen om algemeen in de organisatie geldende gedragskenmerken betreffende teamfunctioneren als irrelevante gedragsitems op te nemen. Alle schalen bleken na toetsing voldoende betrouwbaar te zijn. In een semigestructureerd interview zijn deze variabelen met tien oud-deelnemers besproken en gespecificeerd. Uit deze interviews is wederom duidelijk geworden, dat complexe 
gedragscomponenten moeilijk in eenduidige gedragscriteria te beschrijven zijn zoals Fishbein en Ajzen $(1975,2010)$ deze hanteren. Een voorbeeld is in kader 5.1 weergegeven.

Kader 5.1

De stelling dat een persoon op tijd op het werk verschijnt, is gemakkelijker in 'tijd', 'situatie', 'plaats', 'context' en 'doel' te formuleren. Zo kan worden aangegeven, dat een persoon iedere reguliere werkdag tussen 08.00 uur en 08.30 uur op het werk zal verschijnen of niet. Het houden van een functioneringsgesprek daarentegen bestaat uit diverse waarneembare gedragingen. Naast het bespreken van het functioneren zullen bijvoorbeeld ook non-verbaal gedrag (knikken, hummen, doorvragen), reageren op de ander en het invullen van het formulier gedragsaspecten zijn in een 'goed' functioneringsgesprek. Strikt genomen zouden al deze aspecten gescheiden van elkaar in afzonderlijke vragen moeten worden geformuleerd.

De uitkomsten van de interviews zijn met de resultaten uit de ontwikkeling van het meetinstrument en de toepassing in de eerder uitgevoerde casestudies onderling vergeleken en tot één meetinstrument uitgewerkt. De uitkomst was een conceptvragenlijst bestaande uit 47 inhoudelijke vragen:

- 23 vragen die relevant zijn voor de leerdoelen van de training;

- 8 irrelevante vragen betreffend de IRS;

- 16 vragen betreffend het 'Reasoned Action Model' uit de 'Reasoned Action Approach'.

Ook hierbij kon conform de aanbevelingen van Fishbein en Ajzen (2010) op iedere vraag of stelling een waardering worden gegeven, waaraan verschillende uitersten gekoppeld waren. Bij de ontwikkeling van de diverse schalen zijn de vragen dusdanig aangepast dat deze in principe, met een enkele aanpassing, voor iedere trainingssituatie van toepassing zijn en breed kunnen worden ingezet. Anders dan bij eerder onderzoek is door de projectgroep voor een 6-puntsschaal gekozen. Volgens de P\&O-functionarissen van de betreffende organisatie en uit eerder gebruik van de vragenlijst is duidelijk geworden, dat respondenten de neiging hebben om neutraal (dat wil zeggen het middelpunt) te kiezen. Een aantal voorbeeldvragen:

Stelling: Ik maak het belang van SFBP duidelijk aan de medewerker.

Antwoord: $\quad$ altijd $\square-\square-\square-\square-\square-\square$ nooit

Stelling: Ik ken mijn rol in het functioneringsgesprek.

Antwoord: geheel wel $\square-\square-\square-\square-\square-\square$ geheel niet

Stelling: Ik ben van plan om de komende 6 maanden te werken aan SFBP.

Antwoord: zeer zeker $\square-\square-\square-\square-\square-\square$ zeer zeker niet 
Bij de casestudies (hoofdstuk 4) is verzuimd de betrouwbaarheid en validiteit opnieuw te toetsen, waardoor de uitkomsten aan waarde verliezen. Derhalve is bij dit onderzoek ervoor gekozen de expertvaliditeit en betrouwbaarheid te onderzoeken. Een expertgroep bestaande uit drie medewerkers, een oud-deelnemer en drie P\&O-adviseurs van de organisatie hebben de vragen, die at random werden aangeboden, aan de diverse, van te voren beoogde subschalen toegedeeld. Alleen de vragen die door deze groep met meer dan $80 \%$ daadwerkelijk aan de betreffende schaal zijn toegewezen, zijn verder in dit deelonderzoek verwerkt. Hierdoor kwamen twee vragen van de oorspronkelijk 47 vragen niet meer in aanmerking voor verder onderzoek en zijn deze uit de conceptvragenlijst verwijderd. Vervolgens is, conform de gekozen onderzoeksopzet, deze conceptvragenlijst getoetst op betrouwbaarheid door de test-hertestbetrouwbaarheid te berekenen (gepaarde $t$-test) met een interval van $1 \frac{1}{2}$ week tussen de eerste en tweede afname. De uitkomsten daarvan geven voor alle vragen een redelijke stabiliteit weer $(p<.05)$. Ook voor deze vragenlijst is ten behoeve van een onderzoek naar de in het onderzoeksmodel opgestelde schaalindeling uitgevoerd. Hiervoor is de Cronbach's $\alpha$ berekend over de schalen zoals die a priori ontwikkeld waren. Daarbij werd met name gekeken naar de interne consistentie van de schaal, alsmede naar de mate waarin de vragen onderling positief correleerden (binnen een bepaalde schaal ongeacht de hoogte). De uitkomsten laten voor de gekozen schaalindeling een hoge alpha zien en deze varieert van .69 tot .93 (mediaan .75). Nadeel blijft, dat de steekproefomvang $(\mathrm{N}=7)$ erg klein is waardoor de statistische waarde afneemt. Omdat er geen betere alternatieve oplossingen konden worden gevonden is in het verdere onderzoek met deze uitkomsten gewerkt.

Bij vaststellen van de definitieve vragenlijst zijn de volgende criteria gehanteerd:

1. De vragen werden door tenminste $80 \%$ van de experts toegewezen aan de beoogde schaal.

2. De vragen zijn over langere tijd onder gelijke omstandigheden redelijk stabiel in de test-hertestbeoordeling ( $p>.05)$.

3. Cronbach's $\alpha$ bedroeg voor de uiteindelijke schaal tenminste .65 .

4. Alle items binnen de schaal moesten positief met de andere items correleren.

Een overzicht van de uitkomsten is in tabel 5.2 weergegeven:

Tabel 5.2: Resultaten van de vragenlijstontwikkeling

\begin{tabular}{|c|c|c|c|c|c|}
\hline Schaal & Subschaal + items & $\begin{array}{r}\text { Expert } \\
\text { validatie } \\
(N=7)\end{array}$ & $\begin{array}{r}\text { Test-Hertest } \\
\text { Betrouw- } \\
\text { baarheid } \\
(N=7)\end{array}$ & $\begin{array}{r}\text { Cronbach's } \\
\alpha \text { meting } 1 \& 2 \\
(N=7)\end{array}$ & $\begin{array}{r}\text { Definitief } \\
\text { verwijderd }\end{array}$ \\
\hline \multirow{6}{*}{$\begin{array}{l}\text { Relevante } \\
\text { schaal }\end{array}$} & Gespreksvoering & & \multirow{6}{*}{$\begin{array}{r}p>.05 \text { voor } \\
\text { alle items }\end{array}$} & $\alpha=.69$ & \\
\hline & $\begin{array}{l}\text { Ik benader medewerkers op een positieve } \\
\text { wijze. }\end{array}$ & $86 \%$ & & .56 & \\
\hline & $\begin{array}{l}\text { Ik maak SMART afspraken over de te beha- } \\
\text { len doelen, taken en verantwoordelijkhe- } \\
\text { den van de mw. }\end{array}$ & $93 \%$ & & .61 & \\
\hline & $\begin{array}{l}\text { Ik houd rekening met mijn kwaliteiten en } \\
\text { valkuilen in gespreksvoering. }\end{array}$ & $100 \%$ & & .57 & \\
\hline & $\begin{array}{l}\text { Ik heb de basiskennis op het gebied ge- } \\
\text { sprekstechnieken, om SFB te voeren. }\end{array}$ & $100 \%$ & & .62 & \\
\hline & $\begin{array}{l}\text { Ik benader medewerkers op een confronte- } \\
\text { rende wijze. }\end{array}$ & $86 \%$ & & .61 & \\
\hline
\end{tabular}




\begin{tabular}{|c|c|c|c|c|c|}
\hline & Subschaal + items & $\begin{array}{r}\text { Expert } \\
\text { validatie } \\
(N=7)\end{array}$ & $\begin{array}{r}\text { Test-Hertest } \\
\text { Betrouw- } \\
\text { baarheid } \\
(N=7)\end{array}$ & $\begin{array}{r}\text { Cronbach's } \\
\alpha \text { meting } 1 \& 2 \\
(N=7)\end{array}$ & $\begin{array}{r}\text { Definitief } \\
\text { verwijderd }\end{array}$ \\
\hline & Ik geef constructieve feedback. & $100 \%$ & & .66 & \\
\hline & $\begin{array}{l}\text { Ik geef de ruimte aan de medewerker om } \\
\text { mij ook feedback te geven (start- en functi- } \\
\text { oneringsgesprek). }\end{array}$ & $93 \%$ & & .66 & \\
\hline & $\begin{array}{l}\text { Ik heb de basisvaardigheden, op het gebied } \\
\text { gesprekstechnieken, om SFB te voeren }\end{array}$ & $100 \%$ & & .53 & \\
\hline & $\begin{array}{l}\text { Ik denk mee over de loopbaanwensen van } \\
\text { medewerkers en mogelijkheden die hierop } \\
\text { aansluiten. }\end{array}$ & $93 \%$ & & 67 & \\
\hline & $\begin{array}{l}\text { Ik ben me bewust van het effect van het } \\
\text { individu op het grotere geheel (organisatie- } \\
\text { belang). }\end{array}$ & $71 \%$ & & .70 & * \\
\hline & Regels \& procedures & & $p>.05$ voor & $\alpha=.86$ & \\
\hline & Ik ken mijn rol in het startgesprek. & $100 \%$ & alle items & .73 & \\
\hline & $\begin{array}{l}\text { Ik maak het belang van SFB duidelijk aan de } \\
\text { medewerker. }\end{array}$ & $93 \%$ & & .81 & \\
\hline & $\begin{array}{l}\text { Ik gebruik de instrumenten die de organisa- } \\
\text { tie biedt voor het voeren van SFB. }\end{array}$ & $93 \%$ & & .79 & \\
\hline & $\begin{array}{l}\text { Ik ben me bewust van de relaties tussen } \\
\text { start-, functionerings-, beoordelings- en } \\
\text { popgesprek. }\end{array}$ & $100 \%$ & & .75 & \\
\hline & Ik ken mijn rol in het functioneringsgesprek. & $100 \%$ & & .74 & \\
\hline & $\begin{array}{l}\text { Ik houd me aan het beoordelingsvoorschrift } \\
\text { van de organisatie. }\end{array}$ & $93 \%$ & & .79 & \\
\hline & Ik houd me aan de gesprekkencyclus. & $100 \%$ & & .78 & \\
\hline & $\begin{array}{l}\text { Tijdens de cyclus SFB geef ik ook tussentijd- } \\
\text { se, informele terugkoppeling en feedback. }\end{array}$ & $93 \%$ & & .76 & \\
\hline & Ik ken mijn rol bij beoordelen. & $100 \%$ & & .80 & \\
\hline & Ik ken mijn rol in het pop-gesprek. & $100 \%$ & & .81 & \\
\hline & Beoordelen & & $p>.05$ voor & $\alpha=.93$ & \\
\hline & $\begin{array}{l}\text { Ik oordeel zorgvuldig, op basis van voldoen- } \\
\text { de informatie. }\end{array}$ & $100 \%$ & alle items & .12 & \\
\hline & $\begin{array}{l}\text { Ik houd rekening met mijn kwaliteiten en } \\
\text { valkuilen in beoordelen. }\end{array}$ & $100 \%$ & & .80 & \\
\hline & $\begin{array}{l}\text { Ik oordeel }(A / B / C / D) \text { kritisch, op basis van } \\
\text { concrete voorbeelden. }\end{array}$ & $0 \%$ & & .79 & * \\
\hline \multirow{9}{*}{$\begin{array}{l}\text { Irrelevante } \\
\text { schaal }\end{array}$} & Teamfunctioneren & & $p>.05$ voor & $\alpha=.74$ & \\
\hline & $\overline{\text { Op onze afdeling heerst een teamgevoel. }}$ & $86 \%$ & alle items & .62 & \\
\hline & $\begin{array}{l}\text { Ik draag eraan bij dat mijn collega's en } \\
\text { leidinggevende zo goed mogelijk hun werk } \\
\text { kunnen uitvoeren. }\end{array}$ & $93 \%$ & & .63 & \\
\hline & $\begin{array}{l}\text { Op de afdeling waar ik werk motiveren } \\
\text { collega's elkaar. }\end{array}$ & $86 \%$ & & .68 & \\
\hline & $\begin{array}{l}\text { Als ik in een team werk probeer ik ervoor te } \\
\text { zorgen dat iedereen optimaal kan functio- } \\
\text { neren. }\end{array}$ & $100 \%$ & & .59 & \\
\hline & $\begin{array}{l}\text { Wanneer ik iets geleerd heb, houd ik dit } \\
\text { meestal voor mezelf. }\end{array}$ & $93 \%$ & & .68 & \\
\hline & $\begin{array}{l}\text { Ik probeer mijn kennis te delen met mijn } \\
\text { collega's. }\end{array}$ & $100 \%$ & & .58 & \\
\hline & Ik ken de collega's van mijn directie. & $86 \%$ & & .62 & \\
\hline & $\begin{array}{l}\text { Ik vind het fijn om met mijn collega's samen } \\
\text { te werken. }\end{array}$ & $100 \%$ & & .63 & \\
\hline
\end{tabular}




\begin{tabular}{|c|c|c|c|c|c|}
\hline & Subschaal + items & $\begin{array}{r}\text { Expert } \\
\text { validatie } \\
(N=7)\end{array}$ & $\begin{array}{r}\text { Test-Hertest } \\
\text { Betrouw } \\
\text { baarheid } \\
(N=7)\end{array}$ & $\begin{array}{r}\text { Cronbach's } \\
\text { a meting } 1 \& 2 \\
(N=7)\end{array}$ & $\begin{array}{r}\text { Definitief } \\
\text { verwijderd }\end{array}$ \\
\hline \multirow{20}{*}{$\begin{array}{l}\text { Vragen } \\
\text { lijst } \\
\text { gebaseerd } \\
\text { op het } \\
\text { 'Reasoned } \\
\text { Action } \\
\text { Model' }\end{array}$} & Ervaren controle & & $p>.05$ voor & $\alpha=.67$ & \\
\hline & $\begin{array}{l}\text { Om tijdens het dagelijkse werk aan SFB te } \\
\text { werken is voor mij }\end{array}$ & $100 \%$ & alle items & .62 & \\
\hline & $\begin{array}{l}\text { Ongeacht de omstandigheden ben ik zelf } \\
\text { verantwoordelijk voor het werken aan SFB. }\end{array}$ & $100 \%$ & & .57 & \\
\hline & $\begin{array}{l}\text { Er doen zich situaties voor waarin ik kan } \\
\text { werken aan SFB. }\end{array}$ & $100 \%$ & & .42 & \\
\hline & $\begin{array}{l}\text { Er zijn goede redenen om te werken aan } \\
\text { SFBP. }\end{array}$ & $100 \%$ & & .43 & \\
\hline & Attitude & & $p>.05$ voor & $\alpha=.93$ & \\
\hline & $\begin{array}{l}\text { Het werken aan SFB heeft invloed op mijn } \\
\text { eigen performance/prestatie }\end{array}$ & $100 \%$ & alle items & .79 & \\
\hline & Om te werken aan SFB vind ik & $100 \%$ & & .70 & \\
\hline & Het werken aan SFB is voor mij & $100 \%$ & & .62 & \\
\hline & $\begin{array}{l}\text { Om de komende } 6 \text { maanden aan SFB te } \\
\text { werken is }\end{array}$ & $100 \%$ & & .73 & \\
\hline & Intentie & & $p>.05$ voor & $\alpha=.80$ & \\
\hline & $\begin{array}{l}\text { Dat ik meer aandacht ga besteden aan het } \\
\text { werken aan SFB is... }\end{array}$ & $100 \%$ & alle items & .75 & \\
\hline & $\begin{array}{l}\text { Ik ben er zeker van dat ik kan bijdragen aan } \\
\text { verbetering van mijn SFB. }\end{array}$ & $100 \%$ & & .76 & \\
\hline & $\begin{array}{l}\text { Volgend jaar heb ik een bijdrage geleverd } \\
\text { aan verbetering van mijn SFB. }\end{array}$ & $100 \%$ & & .79 & \\
\hline & $\begin{array}{l}\text { Ik ben van plan om de komende } 6 \text { maanden } \\
\text { te werken aan SFB }\end{array}$ & $100 \%$ & & .75 & \\
\hline & Ervaren Norm & & $p>.05$ voor & $\alpha=.90$ & \\
\hline & $\begin{array}{l}\text { Mijn collega's ondersteunen mij bij het } \\
\text { werken aan SFB }\end{array}$ & $100 \%$ & alle items & .81 & \\
\hline & $\begin{array}{l}\text { Mijn directe leidinggevende stimuleert mij } \\
\text { bij het werken aan SFB }\end{array}$ & $100 \%$ & & .77 & \\
\hline & $\begin{array}{l}\text { Anderen verwachten van mij dat ik werk } \\
\text { aan SFB }\end{array}$ & $100 \%$ & & .79 & \\
\hline & $\begin{array}{l}\text { De collega's van mijn directie willen werken } \\
\text { aan SFB }\end{array}$ & $100 \%$ & & .79 & \\
\hline
\end{tabular}




\subsection{Toepassing in de praktijk}

In het kader van het definitieve onderzoek werden alle potentiële deelnemers benaderd voor deelname aan het onderzoek. Negen daarvan $(N=43)$ namen deel aan de eerste training en acht daarvan namen deel aan de tweede training. De overige 27 zijn in de controlegroep ingedeeld. Van deze 27 hebben 20 personen daadwerkelijk deel genomen aan de controlegroep ten behoeve van het onderzoek. Zowel de experimentele groepen als de controlegroep ontvingen tweemaal het meetinstrument, respectievelijk aan het begin van de training en direct na de training. Voor de controlegroep werd dezelfde tussenperiode aangehouden als de duur van de training (twee dagen). Door onvolledig ingevulde vragenlijsten en non-respons op de nameting vielen gedurende het proces nog 5 deelnemers af, 2 in de interventiegroepen en 3 in de controlegroep. In het definitieve onderzoek zijn uiteindelijk de resultaten van 32 deelnemers verwerkt, 15 in de experimentele groepen en 17 in de controlegroep.

Met een Chi-Kwadraat toets en een variantieanalyse werd onderzocht of de onderzoeksgroepen van elkaar verschilden met betrekking tot leeftijd, geslacht, opleiding, het aantal jaren in de huidige functie, jaren werkervaring en het aantal werkuren (zie tabel 5.3). Dat bleek niet het geval te zijn, multivariante $F(3,29)<.47$, ns. Chi-kwadraat $>2.69, p>$.10. De gemiddelde leeftijd was 51 jaar. $80 \%$ van de deelnemers was mannelijk en $50 \%$ was langer dan 20 jaar werkzaam bij de betreffende organisatie. Meer dan $70 \%$ had minder dan 10 jaar leidinggevende ervaring. Van de deelnemers hadden er 3 personen HAVO als hoogste opleiding, 2 VWO, 3 MBO, 6 hoger beroepsonderwijs en 17 deelnemers hadden een universitaire achtergrond.

Tabel 5.3: Analyse op de algemene gegevens tussen de 3 onderzoeksgroepen

\begin{tabular}{lcccccc}
\hline Variantieanalyse & $\boldsymbol{N}$ & Missing & $d f$ & Mean & $\boldsymbol{F}$ & $\boldsymbol{p}$-waarde \\
\hline Leeftijd & 28 & 4 & 2 & 1957 & .77 & .47 \\
\hline Chi-kwadraat toets & $\boldsymbol{N}$ & Missing & $d f$ & Pearson Chi-Kwadraat & Significantie \\
\hline Geslacht & 30 & 2 & 1 & 2.99 & .10 \\
\hline Opleiding & 29 & 3 & 4 & 2.69 & .61 \\
\hline Ervaringsjaren & 29 & 3 & 7 & 8.40 & .23 \\
\hline Werkuren & 30 & 2 & 5 & 5.60 & .35 \\
\hline Jaren in functie & 29 & 3 & 5 & 9.01 & .10 \\
\hline ( $p<.05=$ significant verschil) & & & & &
\end{tabular}

Omdat de groepsomvang van de twee experimentele groepen $(N<9)$ en de controlegroep ( $N=17$ ) sterk van elkaar verschillen, is onderzocht of voor de uiteindelijke berekeningen de separate interventiegroepen als één onderzoeksgroep konden worden gezien binnen hun eigen trainingsprogramma. Hiervoor is onderzocht of de twee experimentele groepen binnen hun programma over de twee meetmomenten niet significant van elkaar zouden verschillen. Met behulp van een $t$-test voor onafhankelijke steekproeven is derhalve onderzocht of beide experimentele groepen op de verschillende onderzoeksvariabelen, zowel tijdens de voormeting als de nameting, in hun antwoorden niet significant van elkaar verschillen. 
De uitkomsten laten zien dat op nagenoeg alle onderdelen geen significant verschil tussen de twee experimentele groepen is aangetroffen $(p>.05)$. Slechts voor de subschaal 'intentie' bij de voormeting is een significant verschil aangetroffen $(p=0.03)$. Met de samenvoeging van de twee groepen valt dit effect weg. In tabel 5.4 is een overzicht van de uitkomsten weergegeven.

Tabel 5.4: Uitkomsten t-test voor de twee experimentele groepen (voor- en nameting)

\begin{tabular}{|c|c|c|c|c|c|c|c|}
\hline & $N$ & Missing & $d f$ & $t$ & SD & Mean (1-6) & $p$-waarde \\
\hline Relevante schaal (voormeting) & 15 & 0 & 13 & -2.11 & 0.39 & 4.70 & 0.055 \\
\hline Relevante schaal (nameting) & 15 & 0 & 13 & 0.05 & 0.28 & 5.25 & 0.823 \\
\hline Irrelevante schaal (voormeting) & 15 & 0 & 13 & 1.64 & 0.31 & 5.19 & 0.126 \\
\hline Irrelevante Schaal (nameting) & 15 & 0 & 13 & 1.83 & 0.40 & 5.22 & 0.090 \\
\hline Attitude (voormeting) & 15 & 0 & 13 & -2.11 & 0.86 & 4.43 & 0.080 \\
\hline Attitude (nameting) & 15 & 0 & 13 & -0.56 & 0.60 & 5.13 & 0.608 \\
\hline Ervaren Controle (voormeting) & 15 & 0 & 13 & -1.10 & 0.59 & 4.36 & 0.055 \\
\hline Ervaren Controle (nameting) & 15 & 0 & 13 & -0.15 & 0.49 & 5.18 & 0.582 \\
\hline Ervaren Norm (voormeting) & 15 & 0 & 13 & -2.11 & 0.72 & 4.06 & 0.065 \\
\hline Ervaren Norm (nameting) & 15 & 0 & 13 & 0.67 & 0.52 & 4.50 & 1.000 \\
\hline Intentie (voormeting) & 15 & 0 & 13 & -2.44 & 0.69 & 4.40 & $0.030 *$ \\
\hline Intentie (nameting) & 15 & 0 & 13 & -0.77 & 0.45 & 4.67 & 0.748 \\
\hline
\end{tabular}

Op basis van de bovenstaande uitkomst zijn de gegevens van beide groepen tot één experimentele groep samengevoegd. Hierdoor werd een grotere groepsomvang gerealiseerd, wat ten goede komt aan de statistische verwerking. Voor verdere berekeningen werd uitgegaan van een experimentele groep van 15 personen en een controlegroep van 17 personen. De aanname is, dat de experimentele groep een significante groei laat zien op de relevante vragen (het beoogde gedrag van de training) en de vragen die gericht zijn op de toepassing van het nagestreefde gedrag in de praktijk bevorderen (de vragen uit de 'Reasoned Action Approach' van Fishbein en Ajzen, 2010). Voor de irrelevante vragen was de veronderstelling dat er geen verandering zou plaatsvinden. Voor de controlegroep was de veronderstelling, dat de scores op alle vragen gelijk zouden blijven (Garson, 2008). Met een dergelijk resultaat zou er, naast een uitspraak over het effect van de training, ook een uitspraak gedaan kunnen worden over de bruikbaarheid van de IRS-werkmethode bij onderzoek zonder controlegroep. Bovendien zou de eerder gekozen vragenlijst en methode ook zonder controlegroep kunnen worden toegepast, wanneer er een verschil tussen de relevante en irrelevante items bij de experimentele groep wordt aangetroffen, terwijl dat bij de controlegroep niet zo is. Deze aanname is in eerste instantie getoetst met behulp van een gepaarde t-toets voor de voor- en nameting bij zowel de experimentele groep als de controlegroep. Bij wijze van exploratie is daarnaast ook nagegaan wat de uitkomsten zijn, als alleen de nametingen gebruikt worden in de analyse. Daarmee wordt duidelijk wat het belang is van een voormeting. Ten slotte is tevens een co-variantieanalyse uitgevoerd, waarmee alle data in één keer verwerkt zijn. 


\subsection{Resultaten}

Een eerste vergelijking van de somscores op de onderzochte variabelen tussen de experimentele groep en de controlegroep laat een verschil zien in de uitkomsten tussen voor- en nameting. Wat de uitgangswaarde van de voormeting betreft, verschillen de twee groepen nauwelijks van elkaar. Bij de experimentele groep is, zoals verwacht, op alle variabelen een stijging waar te nemen, behalve op de irrelevante schaal. Deze blijft nagenoeg gelijk. Bij de controlegroep is, zoals verwacht, nagenoeg geen verandering op alle schalen waar te nemen (zie grafiek 5.1).

Grafiek 5.1: Relatieve scores op de 2 metingen
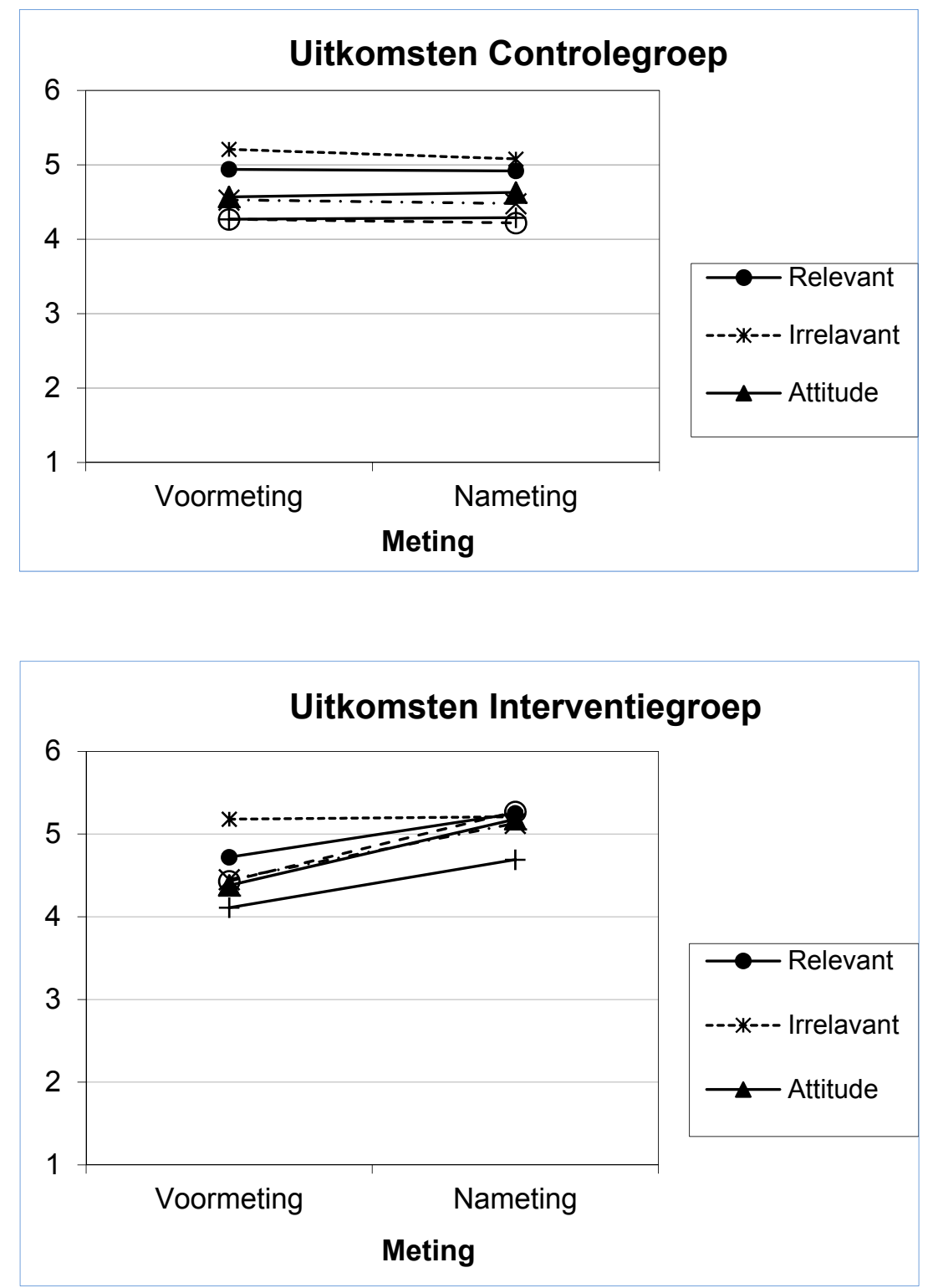
Om te toetsen of er verschil aan te treffen is tussen de voor- en de nameting, werd gebruik gemaakt van een gepaarde $t$-toets voor beide groepen (tabel 5.5). De veronderstelling was dat er voor de experimentele groep statistisch gezien een significant verschil tussen de voor- en de nameting te constateren is, wat de onderzoeksvariabelen betreft. Wat de irrelevante schaal betreft, wordt geen significant verschil verwacht. Voor de controlegroep wordt statistisch gezien voor alle schalen geen significant verschil tussen voor- en nameting verwacht. Nadeel blijft de kleine steekproefomvang.

Bij de experimentele groep toont een analyse van de effecten met betrekking tot de inhoudelijke (leer)doelen tussen de voor- en nameting (door middel van een gepaarde $t$ test) de verwachte significante verschillen aan op alle onderzoeksschalen, alle $t$ 's (14) > $2.28, p<.05$. Voor de irrelevante schaal wordt geen significant verschil aangetroffen $(t(14)=-0.4, p=0.69)$.

Tabel 5.5: Gepaarde t-test (factor tijd) voor de experimentele groep

\begin{tabular}{lrrrrrrr} 
& $\boldsymbol{N}$ & Missing & $\boldsymbol{d f}$ & $\boldsymbol{t}$ & $\boldsymbol{S D}$ & Mean & $\boldsymbol{p}$-waarde \\
\hline Relevante schaal & 15 & 0 & 14 & -4.37 & 0.46 & -0.53 & 0.001 \\
\hline Irrelevante schaal & 15 & 0 & 14 & -0.40 & 0.27 & -0.03 & 0.695 \\
\hline Attitude & 15 & 0 & 14 & -6.07 & 0.51 & -0.80 & 0.000 \\
\hline Ervaren Controle & 15 & 0 & 14 & -4.11 & 0.64 & -0.68 & 0.001 \\
\hline Ervaren Norm & 15 & 0 & 14 & -2.28 & 0.88 & -0.52 & 0.039 \\
\hline Intentie & 15 & 0 & 14 & -5.72 & 0.56 & -0.83 & 0.000 \\
\hline$(p<.05=$ significant verschil) & & & & & & &
\end{tabular}

Bij de controlegroep werden (tabel 5.6) daarentegen op geen enkele schaal significante verschillen aangetroffen tussen de voor- en de nameting, alle $t^{\prime} s(16)<1.68$, ns.

Tabel 5.6: Gepaarde t-test (factor tijd) voor de controlegroep

\begin{tabular}{lcrrrrrr} 
& $\boldsymbol{N}$ & Missing & $\boldsymbol{D f}$ & $\boldsymbol{t}$ & $\boldsymbol{S D}$ & Mean & $\boldsymbol{p}$-waarde \\
\hline Relevante schaal & 17 & 0 & 16 & 0.83 & 0.10 & 0.02 & 0.42 \\
\hline Irrelevante schaal & 17 & 0 & 16 & 1.68 & 0.31 & 0.13 & 0.11 \\
\hline Attitude & 17 & 0 & 16 & -0.94 & 0.26 & -0.06 & 0.36 \\
\hline Ervaren Controle & 17 & 0 & 16 & 1.14 & 0.16 & 0.04 & 0.27 \\
\hline Ervaren Norm & 17 & 0 & 16 & -0.52 & 0.23 & -0.03 & 0.61 \\
\hline Intentie & 17 & 0 & 16 & 0.62 & 0.30 & 0.05 & 0.54 \\
\hline$(p<.05=$ significant verschil) & & & & & & & \\
\hline
\end{tabular}

De hiervoor uitgevoerde analyse met een gepaarde $t$-test suggereert, dat er veranderingen tussen de voor- en de nameting hebben plaatsgevonden. Zoals verwacht is er voor de experimentele groep een verandering op alle relevante schalen aangetroffen. De scores op de irrelevante schaal zijn daarentegen gelijk gebleven. Bij de controlegroep zijn op alle schalen geen significante veranderingen tussen de voor- en de nameting aangetroffen. Men zou dus kunnen veronderstellen, dat de training invloed heeft gehad op de waargenomen scores. Omdat de uitgangspositie tussen de groepen mogelijk verschillend is, is tevens met behulp van een t-toets voor onafhankelijke steekproe- 
ven onderzocht of er een significant verschil was tussen de twee groepen voor zowel de voor- als de nameting (zie ter illustratie kader 5.2).

Kader 5.2

Stel je hebt twee groepen hardlopers: één groep krijgt specifieke training en de andere groep niet. Door toeval zijn alle topatleten in de controlegroep terecht gekomen waardoor zij zowel bij de voor- als bij de nameting weliswaar een zeer hoge score behalen, maar er geen verschil tussen de metingen aan te treffen is. Dat is ook logisch, omdat zij reeds op topniveau presteren. De interventiegroep bestaat uit laag presterende atleten, die door de training significant beter presteren, maar nog steeds onder het niveau van de controlegroep. In dat geval kan alleen worden aangenomen dat de specifieke training verbetering geeft voor de prestatie van laag presterende sporters, maar er nog steeds geen topsporters van maakt. Om een uitspraak te kunnen doen over de toegevoegde waarde van deze training voor alle sporters, is het noodzakelijk de groepen op verschillen op de voor- en de nameting te onderzoeken.

De uitkomst van de analyse op de voormeting tussen de experimentele groep en de controlegroep laat zien, dat er geen verschil is tussen de twee groepen. De $t$-toets voor onafhankelijke steekproeven (tabel 5.7) wees uit, dat de gemiddelde scores van de controlegroep en de experimentele groep niet significant van elkaar verschillen, $t(30)>-$ $0.18, \mathrm{~ns}$.

Bij de irrelevante schaal liet de $t$-toets eveneens geen significant verschil zien tussen de gemiddelde scores van de experimentele groep en de gemiddelde score van de controlegroep, $t(30)=-0.18$, ns.

Tabel 5.7: t-test (groep) voormeting - experimenteel / controle

\begin{tabular}{llrrrrr} 
& $\boldsymbol{N}$ & Missing & $\boldsymbol{d f}$ & $\boldsymbol{t}$ & $\boldsymbol{F}$ & $\boldsymbol{p}$-waarde \\
\hline Relevante schaal & 32 & 0 & 30 & -1.15 & 0.14 & 0.26 \\
\hline Irrelevante schaal & 32 & 0 & 30 & -0.18 & 2.45 & 0.86 \\
\hline Attitude & 32 & 0 & 30 & -0.84 & 0.02 & 0.41 \\
\hline Ervaren Controle & 32 & 0 & 30 & -0.32 & 1.10 & 0.75 \\
\hline Ervaren Norm & 32 & 0 & 30 & -0.65 & 0.46 & 0.52 \\
\hline Intentie & 32 & 0 & 30 & 0.66 & 0.55 & 0.51 \\
\hline$(p<.05=$ significant verschil) & & & & & &
\end{tabular}

Dezelfde analyse is voor de nameting uitgevoerd (tabel 5.8). Daarbij is met behulp van een t-toets voor onafhankelijke steekproeven geen significant verschil aangetroffen voor de factor ervaren norm uit het 'Reasoned Action Model', $t(30)=0.09$, ns, en (zoals verwacht) geen verschil voor de irrelevante schaal $t(30)=0.82$, ns. Voor alle andere factoren werden wel verschillen aangetroffen tussen de gemiddelde scores van de interventie en de controlegroep, $t(30)>1.77, p<.05$. 
Tabel 5.8: -test (groep) nameting - experimenteel / controle

\begin{tabular}{llrlrrr} 
& $\boldsymbol{N}$ & Missing & $\boldsymbol{d f}$ & $\boldsymbol{t}$ & $\boldsymbol{F}$ & $\boldsymbol{p}$-waarde \\
\hline Relevante schaal & 32 & 0 & 30 & 2.01 & 1.22 & 0.05 \\
\hline Irrelevante schaal & 32 & 0 & 30 & 0.82 & 0.00 & 0.42 \\
\hline Attitude & 32 & 0 & 30 & 2.74 & 2.21 & 0.00 \\
\hline Ervaren Controle & 32 & 0 & 30 & 3.48 & 0.61 & 0.09 \\
\hline Ervaren Norm & 32 & 0 & 30 & 1.77 & 0.56 & 0.01 \\
\hline Intentie & 32 & 0 & 30 & 4.98 & 0.20 & 0.00 \\
\hline$(p<.05=$ significant verschil) & & & & & & \\
\hline
\end{tabular}

Om een gefundeerde uitspraak te kunnen doen over de effecten van de training binnen de onderzoeksgroep gedurende de training, is gebruik gemaakt van een covariantieanalyse op de hoofdschalen over de nametingen met de voormeting als covariaat. De uitkomsten laten zien dat, wat de irrelevante schaal betreft, binnen de onderzoeksgroepen zelf geen significant verschil aan te treffen is $(p=.21$, ns) tussen de voor- en de nameting. Op alle andere schalen is dat wel het geval $(F>16.25, p<.02)$.

Hieruit valt af te leiden, dat bij de experimentele groep gedurende de training veranderingen hebben plaatsgevonden en bij de controlegroep niet. Voor de aspecten van de irrelevante schaal heeft voor beide groepen geen verandering plaatsgevonden. 


\subsection{Conclusies}

In dit deelonderzoek is de aanname, dat IRS een goed toepasbare methode is om zonder controlegroep een effectstudie uit te kunnen voeren, onderzocht. Met IRS worden de effecten van een training of interventie vergeleken met gedragsaspecten die juist niet zouden moeten worden beïnvloed. De doelstelling was om met behulp van IRS aan te tonen, dat de eerder ontwikkelde vragenlijst gebaseerd op de 'Reasoned Action Approach' in voldoende mate de effecten van een gedragsinterventie meet, zonder dat het gebruik van een controlegroep noodzakelijk is. Hiervoor is het onderzoeksdesign dat voor de ontwikkeling van de vragenlijst gebaseerd op de 'Reasoned Action Approach' is ontwikkeld, aangevuld met het concept van IRS. Tevens is het onderzoekinstrumentarium op betrouwbarheid en expertvaliditeit onderzocht. Twee experimentele groepen hebben een training 'Start-, Functionerings- en Beoordelingsgesprekken' gevolgd en een controlegroep heeft geen training gevolgd.

Een analyse van de ontwikkelingen met betrekking tot nagestreefd (relevant) gedrag tussen de voor- en nameting toonde voor de experimentele groep de verwachte verschillen aan. Bij de controlegroep werd geen enkel verschil aangetroffen. Wat de factoren ('attitude', 'ervaren controle', 'ervaren norm' en 'intentie') uit het 'Reasoned Action Model' betreft, werden voor de experimentele groep voor alle factoren duidelijke verschillen aangetroffen tussen de voor- en de nameting. Bij de controlegroep werden geen verschillen aangetroffen. Deze zijn binnen de geboden mogelijkheden met behulp van t-testen (gepaarde en enkelvoudige) statistisch onderzocht. Weliswaar is door de kleine steekproefomvang de kans op toevalfouten erg groot, maar de uitkomsten suggereren, dat de training de beoogde effecten had. Voor de irrelevante schaal (voor de IRS) werden bij geen van beide groepen verschillen tussen de voor- en de nameting aangetroffen. Een toets voor onafhankelijke steekproeven met betrekking tot het gewenste gedrag van de training (relevante items) wees uit, dat de gemiddelde scores van de controlegroep en van de experimentele groep op dit onderdeel niet significant van elkaar verschilden. Bij de irrelevante schaal liet de toets eveneens geen significant verschil zien tussen de gemiddelde score van de experimentele groep en de gemiddelde score van de controlegroep. Wat betreft de factoren uit het 'Reasoned Action Model' werd voor de factor 'ervaren norm' géén significant verschil aangetoond. Voor alle andere factoren werden wel significante verschillen aangetroffen tussen de gemiddelde scores van de experimentele groep en van de controlegroep. Een verklaring hiervoor is, dat de controlegroep op de voormeting - hoewel niet significant - hoger scoorde dan de experimentele groep. Hierdoor kan het zijn, dat de groei die de interventiegroep heeft doorgemaakt niet zichtbaar is in vergelijking met de controlegroep. Als laatste is een co-variantieanalyse uitgevoerd op de hoofdschalen over de nametingen met de voormeting als co-variaat.

De uitkomsten laten zien, dat er, wat de irrelevante schaal betreft, tussen de twee onderzoeksgroepen geen significant verschil was. Op alle andere schalen is dat wel het geval. De aanname dat de experimentele groep in vergelijking met de controlegroep een grotere groei op de relevante vragen en op de vragen gericht op de invloedfactoren uit het 'Reasoned Action Model' zou laten zien, is hiermee bevestigd.

Zoals verwacht maakte alleen de experimentele groep een significante groei door tijdens de training. De controlegroep liet geen verandering zien. De score op de irrelevante schaal bleef bij beide groepen stabiel. Hieruit zou geconcludeerd kunnen worden, 
dat de verandering die bij de experimentele groep optrad aan de training toegeschreven kan worden. Naast het gemeten effect heeft het onderzoek tevens uitgewezen, dat de irrelevante schaal (IRS-schaal) daadwerkelijk stabiel blijft, wat aangeeft dat onderzoek naar gedragsverandering volgens het gekozen design in de toekomst zonder controlegroep zou kunnen worden uitgevoerd. 


\section{Conclusies en discussie}

In dit onderzoek stond de vraag centraal hoe de effectiviteit van gedragsinterventies (gedragstrainingen) in de praktijk door toepassing van de 'Reasoned Action Approach' kan worden gemeten en vergroot. Tevens is daarbij onderzocht of principes van 'Intervention Mapping' als een methode kunnen dienen om het effect van (gedrags) interventies te versterken en om onderzoeken beter met elkaar te kunnen vergelijken. Ter beantwoording van deze vraagstelling is een aantal deelvragen geformuleerd:

1. Hoe kan de effectiviteit van gedragstrainingen worden gemeten?

2. Welke factoren zijn van invloed op de effectiviteit van gedragstrainingen?

3. Hoe kunnen gedragstrainingen worden geoptimaliseerd?

4. Wat is de invloed van terugkoppeling aan de deelnemers over factoren die een belemmerende en bevorderende werking op het beoogde resultaat hebben?

5. Hoe kunnen interventies op het gebied van gedragsverandering goed met elkaar worden vergeleken?

Om deze deelvragen te kunnen beantwoorden is aan de hand van literatuurstudie, bestaande wetenschappelijke inzichten en 'best practices' als eerste een theoretisch raamwerk ontwikkeld (hoofdstuk 1). De nadruk is daarbij gelegd op het gestructureerd meetbaar maken van procesverbeteringen bij (gedrags)interventies. De uitkomst daarvan is een geïntegreerde methode gebaseerd op de 'Reasoned Action Approach' in combinatie met de principes (en processtappen) van 'Intervention Mapping' (IM). In hoofdstuk 2 is de ontwikkeling van (gedrags)trainingen uiteengezet en zijn de laatste ontwikkelingen aan de hand van reviews van twee decennia onderzoek naar effectiviteit van trainingen besproken. Daarin is duidelijk geworden, dat onderzoek naar effecten en procesverbetering van gedragsinterventies een diffuus werkgebied is en binnen de organisatiekunde nog tamelijk ongestructureerd is, dit in tegenstelling tot onderzoek gericht op gezondheidgerelateerde gedragsverandering (gezond eten, stoppen met roken, infecties vorkomen e.d.), waarbij de directe relatie tussen de te onderzoeken factoren en de negatieve invloed daarvan veel duidelijker te hanteren valt. Een ander verschil is, dat gedragstrainingen in organisaties vaak kortdurend van aard zijn en de steekproefomvang klein is. Aan de hand van deze inzichten is een methode ontwikkeld om het effect van een gedragsinterventie te kunnen meten en het proces daarvan te verbeteren. Deze bestaat uit een vragenlijst gebaseerd op de 'Reasoned Action Approach' (Fishbein \& Ajzen, 2010) in combinatie met de bij IM toegepaste processtappen (hoofdstuk 3). Om na te gaan of de ontwikkelde methode in de praktijk goed gebruikt kan worden, is deze methode in drie casestudies op toepasbaarheid onderzocht (hoofdstuk 4). Omdat in de praktijk de toepassing van de ontwikkelde methode met het gebruik van een controlegroep niet haalbaar was, is naar een alternatief voor dit probleem gezocht. Een goede oplossing bood de toepassing van de 'Internal Referencing Strategy' (IRS) om de statistisch-wetenschappelijke waarde van het meetinstrument te waarborgen (hoofdstuk 5), waardoor de verantwoorde toepassing van de methode in de praktijk mogelijk is.

In dit hoofdstuk worden de uitkomsten gerelateerd aan de deelvragen van dit onderzoek. Vervolgens zullen de conclusies en discussie per deelonderzoek inhoudelijk worden besproken. Tevens zal worden ingegaan op de aangetroffen resultaten met de daarbij behorende beperkingen. Afsluitend worden aanbevelingen voor verder onderzoek en toepassing in de praktijk geformuleerd. 


\subsection{Conclusies en beperkingen betreffend de deelvragen}

In de voorafgaande hoofdstukken is op de deelvragen van dit proefschrift reeds ingegaan. Vooral de ontwikkeling van het meetinstrumentarium (hoofdstuk 3 ) en de toepassing in de praktijk (hoofdstuk 4) hebben een redelijk antwoord op de gefomuleerde vraagstelling opgeleverd. Ook is duidelijk geworden hoe moeilijk onderzoek naar het effect van (gedrags)trainingen is. De kleine steekproefomvang, de korte interventies, de dynamiek van de praktijk en het probleem van het specificeren van gedrag hebben een negatieve invloed op onderzoeksdesign en statistische verwerking. De uitkomsten kunnen dan ook eerder als indicatie worden gezien dat dat er harde, spectaculaire conclusies kunnen worden getrokken. In deze paragraaf worden per deelvraag de belangrijkste conclusies van dit onderzoek besproken.

\section{Hoe kan de effectiviteit van gedragstrainingen worden gemeten?}

Met betrekking tot deelvraag 1 heeft dit onderzoek aangetoond, dat met het ontwikkelde meetinstrument gebaseerd op de 'Reasoned Action Approach' het effect van (gedrags)interventies goed zou kunnen worden gemeten. Zo suggereerde de deelname aan een maatwerkprogramma een beter en langduriger effect te hebben op het beoogde resultaat, dan wanneer een standaardprogramma was gevolgd, en kon dit effect met behulp van het ontwikkelde meetinstrumentatrium ook worden gemeten. Verder bleef bij de uitgevoerde deelonderzoeken de schaalindeling van het ontwikkelde instrument nagenoeg bij alle onderzoeken stabiel (Cronbach's $\alpha$ ), ongeacht verschillen in probleemstelling, (bedrijfs)cultuur en/of taal. Ondanks de eerder geconstateerde beperking dat een respondent geen 'neutraal' antwoord kan geven, bleek de keuze voor een 6-puntsschaal positief voor het onderzoek. De respondenten worden daardoor gedwongen een duidelijke uitspraak te doen in relatie tot de factoren van het 'Reasoned Action Model' ('attitude', 'ervaren controle', 'ervaren norm' en 'intentie') en aanwezige (gewenste) gedrag. Om deelnemers toch de mogelijkheid op een 'niet van toepassing' antwoord te kunnen geven, kan dit worden ondervangen door een vraagteken (voor 'Niet van toepassing' / 'Ik weet het niet') als antwoordmogelijkheid te bieden of te werken met een VAS ('Visual Analogue Scale'), waarbij respondenten op een voorgegeven lijn een kruis mogen zetten. Tevens kunnen door het gebruik van een relatief kleine steekproefomvang voor alle onderzoeken de nodige vraagtekens worden gezet bij de statistische verwerking van de uitkomsten.

Bij de uitwerking van het meetinstrument en de beoogde gedragscriteria bleek het moeilijk het beoogde gedrag altijd zo specifiek mogelijk te omschrijven in termen van 'actie', 'doel', 'context' en 'tijd', zoals Fishbein en Ajzen (2010) dat hebben aangegeven. Hierdoor komt de validiteit van het instrumentarium onder druk te staan. In dat verband bewees de 'Intervention Mapping'- methode zich als een goede aanvulling, omdat samen met de doelgroep naar het probleem en de gewenste uitkomst wordt gekeken. Door de deelnemers in de ontwikkeling van het meetinstrument te laten participeren, was het gemakkelijker de uitkomstcriteria te omschrijven. Verder is in een vervolgonderzoek de betrouwbaarheid en expertvaliditeit voor de betreffende sub-schalen opnieuw onderzocht. Deze bleek voldoende stabiel en betrouwbaar. Ook is in dit onderzoek de aanname bevestigd, dat de 'Reasoned Action Approach' kan worden gebruikt om de effectiviteit van iedere gedragsverandering te kunnen meten onafhankelijk van het design of de interventie die daarbij 
zijn gebruikt (Fishbein \& Ajzen, 2010). Naast het gewenste gedrag wordt ook de opvatting over de toepassing van dat gedrag in de huidige en toekomstige situatie ('intentie')goed in kaart gebracht. Hierdoor kan niet alleen worden vastgesteld in welke mate het gewenste gedrag daadwerkelijk aanwezig is, maar wordt er ook naar gekeken in hoeverre de deelnemers ervan overtuigd zijn dat gedrag in de toekomst toe te kunnen/willen passen. In feite wordt hierdoor door de deelnemers zelf een indicatie gegeven van de daadwerkelijke toepassing van het gewenste gedrag in de huidige situatie én in de toekomst. De drie factoren ('attitude', 'ervaren controle' en 'ervaren norm') uit het 'Reasoned Action Model' gaven in dit onderzoek inzicht in de aanwezige barrières en bieden een goede leidraad voor de te kiezen interventie. De ontwikkelde vragenlijst gaf niet alleen inzicht in het effect van de toegepaste interventie, maar tevens welke van de drie factoren uit het 'Reasoned Action Model' het meeste effect op de beoogde uitkomst heeft uitgeoefend. De vragenlijst bleek gemakkelijk door de deelnemers te kunnen worden ingevuld en in zeer korte tijd statistisch te kunnen worden geanalyseerd. Dit is wel ten koste gegaan van de specificiteit met betrekking tot de gewenste uitkomstcriteria. Met alle beperkingen lijkt de gekozen aanpak en het ontwikkelde instrumentarium een goed middel om het effect van gedragsinterventie in de praktijk te kunnen meten.

\section{Welke factoren zijn van invloed op de effectiviteit van gedragsverandering?}

Minder eenduidig zijn de conclusies met betrekking tot deelvraag 2. De uitkomsten van het literatuuronderzoek en de daarbij opgenomen reviews van Salas en CannonBowers (2001) en Aguinis en Kraiger (2009) steunen de aanname dat het 'Reasoned Action Model' de belangrijkste factoren beschrijft die van invloed zijn op gedragsverandering. Geheel volledig is het model echter niet en het blijft een abstrakte vorm om de werkelijkheid te beschrijven. Vooral de voorspellende waarde van de afzonderlijke deelaspecten van het 'Reasoned Action Model' bij de ontwikkeling van het meetinstrumentarium op het beoogde resultaat (hoofdstuk 3 ) was enigszins teleurstellend. Het concept van de 'Reasoned Action Approach' lijkt in de praktijk complexer dan het daarin gehanteerde model. Andere auteurs, waaronder Alvarez et al. (2004), Coopman et al. (2009) en Obdeijn en Lubberts (2013), proberen in dat verband een meer geïntegreerd en alomvattend beeld te schetsen van de factoren die van invloed zijn op de effectiviteit van gedragsinterventies/trainingen. Alvarez et al. (2004) ontwikkelden zelfs een geïntegreerd model van evaluatie en effectiviteit van training ('Integrated Model of Training Evaluation and Effectiveness'). Daarin wordt de toepassing van de geleerde kennis, kunde en houding in de praktijk ook wel 'transfer' genoemd, die betrekking heeft op de 'verandering in de organisatie' en verwijst naar concrete resultaten in de praktijk. Ook in het 'Dynamisch Oriëntatiemodel' van Coopman et al. (2009) wordt een aantal gedragsmodellen geïntegreerd, om de factoren die van invloed zijn op de effectiviteit van opleidingen te beschrijven. Over de praktische toepassing en het meten van de effectiviteit wordt echter weinig gezegd. Het gaat eerder om verklarende modellen. Door de complexiteit van factoren die van invloed zijn op de effectiviteit van gedragsinterventies/trainingen, moet men voorzichtig zijn om een eenduidige conclusie op dat gebied te trekken. Wellicht is het beter niet zozeer te spreken over factoren die van invloed zijn op de effectiviteit van een interventie, maar over factoren die het proces bevorderen of belemmeren. Hierdoor wordt duidelijker verwezen naar barrières en 'beliefs' uit de 'Reasoned Action Approach', waardoor de focus meer op concreet gedrag wordt gericht. 
De factoren uit het 'Reasoned Action Model' geven in dat geval ook eerder oplossingsrichtingen voor een te kiezen interventie dan een verklaring. Wel laten de uitkomsten van dit onderzoek zien, dat het volgen van een 'maatwerkprogramma' gebaseerd op de 'Reasoned Action Approach' in combinatie met principes van 'Intervention Mapping' een positieve invloed kunnen hebben op het effect van een (gedrags)interventie (zie hoofdstuk 3). Deze aanname wordt versterkt door het feit dat de training(methoden en -inhoud) voor alle groepen gelijk was, met het verschil dat bij de interventiegroep inzicht is gegeven in de voortgang en rekening is gehouden met belemmerende en/of bevorderende factoren ten opzichte van gewenst gedrag. Ook bleek de variabele 'attitude' samen te hangen met het daadwerkelijke waargenomen gedragsvoornemen $(\beta=.40 ; t=2.98 ; p<.01)$ en kan men aannemen dat, naast de deelname aan het maatwerkprogramma, de 'attitude' na de eerste interventie de beste voorspelling geeft voor het beoogde resultaat. Door gebruik te maken van de in het 'Reasoned Action Model' weergegeven factoren ('attitude', 'ervaren controle', 'ervaren norm' en 'intentie') wordt inzicht verschaft in de gedragsverandering belemmerende en bevorderende factoren en kunnen (op korte termijn) realistischere doelstellingen worden geformuleerd, waardoor meer effect wordt behaald, een aanname die ook in onderzoek van McEachan et al. (2014) wordt aangetroffen.

Ook de casestudies (hoofdstuk 4) bevestigen deze aanname. Daarin vormden de aspecten van de 'Reasoned Action Approach' een hulpmiddel om richting te kunnen geven aan de beoogde interventie. Met behulp van de voormeting is, samen met de doelgroep, onderzocht op welke gebieden interventies moeten plaatsvinden en wat daarbij de belemmerende en/of bevorderende factoren zijn. Het dwingt de onderzoeker en doelgroep om zo specifiek mogelijk het gewenste resultaat te beschrijven en de beoogde interventie te 'staven' aan de drie factoren die in het 'Reasoned Action Model' worden weergegeven. Hierdoor wordt ook het (interventie)proces geoptimaliseerd. Daartegenover staat dat de uitkomsten van de statistische onderzoeken enigszins teleurstellend zijn en de gedragscriteria onvoldoende gespecificeerd zijn. Bovendien is bij de casestudies verzuimd om opnieuw de betrouwbaarheid en validiteit van het meetinstrument te onderzoeken. Hierdoor bestaat de kans dat ten onrechte is aangenomen, dat de eerder ontwikkelde vragenlijst ook daadwerkelijk een bijdrage levert aan het beantwoorden van de onderzoeksvraag, een omissie die pas in het vervolgonderzoek in relatie tot het effectonderzoek zonder gebruik van een controlegroep is gecorrigeerd.

\section{Hoe kunnen gedragstrainingen geoptimaliseerd worden?}

Wat deelvraag 3 betreft kon in dit onderzoek worden geillustreerd, dat de principes van 'Intervention Mapping' in combinatie met de toepassing van 'Reasoned Action Approach' een bruikbare methode vormen om het proces van gedragsinterventies/trainingen te optimaliseren. Weliswaar ontbreekt in de casestudies een controlegroep en blijft de longitudinale onderbouwing van deze hypothese beperkt tot één onderzoek (ontwikkeling van het meetinstrument, hoofdstuk 3), maar wel kon duidelijk worden aangetoond dat door toepassing van de in 'Intervention Mapping' beschreven processtappen, door het betrekken van de doelgroep en door het gericht geven van terugkoppeling aan de deelnemers over het beoogde resultaat belemmerende en bevorderende factoren, de effectiviteit van de trainingen is vergroot. 
Vooral uit de regressieanalyse werd duidelijk, dat het volgen van de maatwerkaanpak betere resultaten opleverde dan wanneer dat niet het geval is. Tevens bleek 'attitude' de beste verklarende factor voor het lange-termijneffect ( 3 maanden na de interventie). Bij de ontwikkeling van het onderzoekinstrumentarium is duidelijk geworden, dat maatwerk en terugkoppeling over de aangetroffen resultaten lonen. Met name bij de tweede bijeenkomst van de training (waarin nadrukkelijk het 'Reasoned Action Model' aan bod kwam) bleek de gekozen interventie een duidelijk positief effect te hebben op het beoogde resultaat in vergelijking met de deelnemers van de controlegroep. Hoewel de doelstelling en het programma van beide trainingsgroepen gelijk waren, is bij het maatwerkprogramma meer de nadruk gelegd op de behoeften van de deelnemers. Tevens is de nadruk gelegd op de transfer naar de dagelijkse praktijk door barrières op te sporen en te benoemen. In de groep met het standaardprogramma zijn dezelfde onderwerpen als bij de maatwerkgroep behandeld, waarbij het design en de transfer naar het werk echter niet nadrukkelijk aan bod kwamen. Deze groep laat een meer grillig verloop in hun antwoorden op de vragenlijst zien. Op zich is dat geen verwonderlijke uitkomst: de in deze groep aanwezige 'sinuscurve' (grafiek 3.1) wordt bijvoorbeeld ook door De Caluwé (1997) beschreven. Hij benadrukt dat het leerproces gewoonlijk onregelmatig verloopt: deelnemers leren nieuwe dingen, merken dat het tegenvalt en leren opnieuw. In deze zin is bij de controlegroep een 'klassiek' leerpatroon aanwezig. De interventies in het maatwerkprogramma zijn veel meer gericht op de in het 'Reasoned Action Model' omschreven variabelen en verschaffen de deelnemer inzicht in het eigen functioneren en hoe deze factoren de gewenste uitkomst (gedrag) kunnen beïnvloeden. Op deze manier lijkt het leerproces efficiënter te kunnen verlopen, zonder de ups en downs die het leerproces vaak kenmerken. In deze zin biedt de gekozen aanpak een toegevoegde waarde bij leer- en veranderprocessen. De principes van 'Intervention Mapping' kunnen daarbij als een mogelijke katalysator gezien worden, omdat de voorgeschreven stappen een strategie vormen voor het ontwerp van een interventieprogramma zonder uitspraken te doen over de te kiezen interventies zelf. Hierdoor wordt gebruik gemaakt van aanwezige kennis die ook specifieker aansluit bij de doelgroep. Vooral in de casestudies is dit voordeel duidelijk naar voren gekomen. Daarnaast wordt door toepassing van de 'Internal Referencing Strategy' (IRS) een mogelijke oplossing geboden voor toegepast onderzoek in de praktijk, waarbij geen gebruik kan worden gemaakt van een controlegroep. Omdat de deelonderzoeken wat context, samenstelling van de deelnemers, inhoud en doelstelling sterk van elkaar verschillen, kan deze vraagstelling niet voor de volle $100 \%$ worden beantwoord.

4. Wat is de invloed van terugkoppeling aan de deelnemers over het beoogde resultaat belemmerende en bevorderende factoren?

Met het bij deelvraag 3 gepresenteerde materiaal lijkt ook deelvraag 4 beantwoord. Uit de casestudies is duidelijk geworden dat procesoptimalisatie ook een soort 'nulmeting' is door aan te tonen wat de stand van zaken is met betrekking tot een onderzochte probleemstelling. De toepassing van de ontwikkelde methode en het daarbij behorende meetinstrumentarium zijn een soort 'thermometer' voor de gekozen interventie. Het dwingt onderzoeker en doelgroep het probleem te specificeren, afhankelijkheden te analyseren door begrippen als 'attitude', 'ervaren controle' en 'ervaren norm' te koppelen aan de praktijksituatie en een daarvoor meest optimale interventie te kiezen. Door achteraf het effect te evalueren, wordt over de tijd genomen het proces geoptimaliseerd en worden onnodige kosten voorkomen. Een 
goed voorbeeld betreft het onderzoek bij de kennisorganisatie in Canada (paragraaf 4.4). Het management had de overtuiging dat er geïnvesteerd moest worden in de ontwikkeling van de mensen. Uit het onderzoek is gebleken dat het met betrekking tot de beoogde doelstelling (projectmatig werken) al positief gesteld was binnen de organisatie en de verbetering veel meer door 'effectief management' te behalen viel waardoor in plaats van een hele organisatie slechts enkele managers een interventie hoefden te ondergaan. Economisch gezien een belangrijk aspect, te meer omdat het doorvoeren van een training voor alle deelnemers ook een averechts effect had kunnen oproepen. Medewerkers geloven dan minder in de verandering omdat de oorzaak bij het management ligt en niet bij hen. De ontwikkelde methode zou vooraf inzicht kunnen bieden om de meest optimale interventie te kiezen. Deze uitkomst wordt ook gesteund door andere onderzoeken naar gedragsinterventies gebaseerd op 'Intervention Mapping' (Bartholomew et al., 2006), zoals bijvoorbeeld bij het onderzoek van Koekkoek et al. (2010) waarin wordt aangenomen dat het effect van een interventieprogramma bij psychiatrische patiënten duidelijk meer effect had door 'Intervention Mapping'. Een ander voorbeeld van een onderzoek van de toegevoegde waarde van 'Intervention Mapping' bij gedragsverandering is een onderzoek naar adoptie en transfer van seksuele voorlichting op scholen in Uganda en Indonesië (Leerlooijer et al., 2011) waarin een balans moest worden gevonden tussen logisch-wetenschappelijke inzichten en de acceptatiegraad bij de doelgroep. Daarbij was sprake van duidelijke verbanden tussen interventie en de koppeling tussen gedrag en resultaat. Een voorwaarde dat bij (gedrags)trainingen of organisatievraagstukken minder voor de hand ligt. Ook is het aan te benevelen de in dit onderzoek aangetroffen effecten in een bredere context en binnen een groter steeprof te toetsen.

\section{Hoe kunnen interventies op het gebied van gedragsverandering goed met elkaar worden vergeleken?}

Wat deelvraag 5 betreft, kan worden bevestigd dat het systematisch toepassen van 'Intervention Mapping' in combinatie met een effectmeting gebaseerd op 'Reasoned Action Approach' goed bruikbaar is om onderzoeken naar gedragsverandering met elkaar te kunnen vergelijken. Juist omdat de nadruk wordt gelegd op een duidelijke analyse van het probleem en het meten van daadwerkelijk waarneembaar gedrag is deze aanpak zeer waardevol om in de praktijk toe te passen. Bovendien worden door onderzoeker en doelgroep diverse oplossingsrichtingen onderzocht waardoor diverse soorten modellen en interventies met elkaar kunnen worden vergeleken. Temeer omdat de afzonderlijke factoren die met een probleem verband houden op een systematische en uniforme manier in kaart worden gebracht. Dit is vooral aangetoond bij de toepassing van deze methode in de praktijk (hoofdstukken 3 en 4). Naast een duidelijke definitie van het beoogde resultaat zou men vooraf ook meer inzicht verschaffen in de belemmerende en bevorderende factoren. De daarop gekozen interventie(strategie) kan tevens worden gespecificeerd aan de hand van de in het 'Reasoned Action Model' beoordeelde factoren en sluit aan bij het concept van bijvoorbeeld Poiesz (1999) waarin menselijk gedrag afhankelijk wordt gemaakt aan motivatie, capaciteit en gelegenheid.

Het begrip 'attitude' van Fishbein en Ajzen (2010) verwijst in dat verband naar een interventie om meer inzicht te geven in het 'waarom' en de praktische waarde van het beoogde resultaat voor de deelnemer. 
Vooral bij het onderhoudsbedrijf (paragraaf 5.2) kwam de vraag naar het nut en de noodzaak voor de beoogde verandering veelvuldig aan bod. 'Ervaren norm' is veel meer gericht op groepsprocessen, managementstijl, opvattingen over de verandering vanuit de groepsdynamica. 'ervaren controle' legt meer een link met de aanwezige hulpmiddelen, processen en de vaardigheden van een persoon in relatie tot het gewenste gedrag. Ook hier is het onderhoudsbedrijf uit paragraaf 5.2 een goed voorbeeld. De deelnemers gaven in die casus aan weinig invloed op de verandering uit te kunnen oefenen en ook niet over de daarvoor benodigde middelen te kunnen beschikken. Uit de besproken onderzoeken is ook duidelijk geworden dat het lastig blijft valide en betrouwbaar onderzoek in de praktijk uit te kunnen voeren. Naast de kleine onderzoeksgroepen en is ook de vragenlijst niet geheel consequent en uniform toegepast. Zo is gedurende de onderzoeken een wijziging in de schaal opgetreden en zijn de vragen gedeeltelijk gewijzigd. Hierdoor komen de toch al vanuit statistisch oogpunt zwakke uitkomsten nog meer onder druk te staan. Door in de toekomst de ontwikkelde methode systematisch toe te passen, wordt meer inzicht verschaft over het effect van interventies gegeven de aanwezige situatie. Zo kan het rendement van bijvoorbeeld 'teambuilding' beter worden beoordeeld en vooraf kan worden bepaald welke interventie voor een bepaald probleem de beste oplossingsrichting beidt.

Resumerend moge duidelijk zijn dat de in dit proefschrift besproken onderzoeken zeker geen eenduidig antwoord geven op alle opgestelde deelvragen. Ook hierbij waren onder andere tijdsduur, aanpak, context, opdrachtgever en groepssamenstelling factoren die (statistisch) verantwoorde conclusies in de weg staan. Tevens zijn de inzichten op de gehanteerde theoretische modellen, het 'Reasoned Action Model' en 'Intervention Mapping', gedurende de tijd aan verandering onderhevig geweest waardoor het instrumentarium in de loop van de tijd (gedeeltelijk) is aangepast. Hierdoor wordt de vergelijking van alle onderzoeken met elkaar voor een deel belemmert.

\subsection{Conclusies en beperkingen van het meetinstrument}

Bij de ontwikkeling van het meetinstrument voor dit onderzoek stonden twee vragen centraal. Ten eerste of een vragenlijst gebaseerd op de 'Reasoned Action Approach' gedragsverandering en de daarbij behorende belemmerende en bevorderende factoren kan meten. Ten tweede of door toepassing van de principes van 'Intervention Mapping' een sterker en langduriger effect ten aanzien van het beoogde gedrag kan worden gerealiseerd dan wanneer dat niet wordt gedaan. De resultaten laten zien dat de 'Reasoned Action Approach' een goed toepasbaar concept is voor de ontwikkeling van een meetinstrument voor gedragsverandering. Daarnaast geeft het daarin beschreven 'Reasoned Action Model' een bruikbare theoretische invalshoek bij het ontwerp van een op gedragsverandering gerichte training door een onderscheid te maken in 'intentie', 'attitude', 'ervaren controle' en 'ervaren norm'. De in het onderzoek gebruikte vragenlijst lijkt een mogelijkheid te bieden om het effect van een training positief te beinvloeden door de deelnemer inzicht te verschaffen in de eigen voortgang. In de latere casestudies is nader ingegaan op de aanwezige overtuigingen (Beliefs) ten opzichte van het beoogde gedrag. Een aanvulling die aansluit bij de aanbevelingen van Schaalma (2001), Bartholomew et al. (2006) en Fishbein en Ajzen (2010).

Verder is bij de schaalindeling voor een 6-puntsschaal gekozen in tegenstelling tot de 5of 7-punts schaal die Fishbein en Ajzen (2010) aanbevelen. Tevens zijn de uitkomstvari- 
abelen ('intentie') in een later stadium geclusterd, wat de schaalconstructie ten goede komt en de invloed van kanskapitalisatie verkleind.

Wat betreft de tweede vraag - of door toepassing van 'Intervention Mapping' een sterker en langduriger effect ten aanzien van het beoogde gedrag kan worden gerealiseerd dan wanneer dat niet wordt gedaan - bleek dat 'Intervention Mapping' als praktisch stappenplan voor een beoogde gedragsverandering de opbrengst van een op gedrag gerichte training over de tijd genomen deels verbeterde. De door Schaalma et al. (2001) beschreven onderzoeksopzet en de door Godin en Kok (1996) aanbevolen stappen bieden een goede richtlijn om heldere doelen te stellen en het effect van gedragsverandering op langere termijn op niveau te houden. Om deze vraag te beantwoorden is een longitudinaal onderzoek uitgevoerd, gebruikmakend van een interventie- en een controlegroep. Daarbij is een verbetering op alle variabelen voor de experimentele groep aangetroffen, in tegenstelling tot de controlegroep, waar geen veranderingen werden waargenomen. De follow-upmeting na circa 3 maanden toonde aan, dat de experimentele groep ook na de training de gevonden verbeteringen blijft behouden. Daarbij moet worden opgemerkt, dat aan iedere deelnemer feedback is gegeven op de uitkomst van de vragenlijst. Daarmee heeft deze als een soort 'weegschaal' de deelnemer inzicht gegeven in de aanwezige problematiek en de voortgang van de eigen gedragsverandering; een aanpak die niet expliciet in 'Intervention Mapping' is vastgelegd. In dit geval vormt participatie in het eigen verandertraject al een interventiemethode op zich, die de eigen verantwoordelijkheid voor het veranderproces versterkt. Vanuit statistisch perspectief wordt minder eenduidig aangetoond, dat het volgen van een maatwerkprogramma gebaseerd op 'Intervention Mapping' tot betere resultaten leidt. De doorgevoerde analyses belemmeren krachtige conclusies, temeer omdat het aantal deelnemers erg klein is en er relatief weinig metingen hebben plaatsgevonden.

Zo kent de ontwikkeling van het onderzoeksinstrument en het toegepaste proces een aantal belangrijke beperkingen.

De eerste heeft, zoals eerder aangegeven, betrekking op de kleine steekproefomvang van de onderzoeksgroepen. Het totale aantal deelnemers was 39, verdeeld in 6 groepen van maximaal 8 deelnemers. Hierdoor konden kwalitatief hoogwaardige statistische methoden niet of minder goed worden toegepast, waardoor de statistische power dan wel de bruikbaarheid van de toegepaste toetsen is verminderd. Deels is dit opgelost door de deelgroepen tot een onderzoeksgroep samen te voegen, waardoor de aantallen in de experimentele en de controlegroep zijn toegenomen. Tevens suggereren aangetroffen verschillen tussen de onderzoeksgroepen en tussen de meetmomenten, dat de verschillen tussen de twee onderzoeksgroepen groot genoeg waren om ook met een beperkte statistische power te kunnen worden opgespoord. Aan de andere kant was een factoranalyse naast het onderzoek van expertvaliditeit en -betrouwbaarheid zeer bruikbaar geweest bij de constructie van de uiteindelijke schalen.

Een tweede beperking van dit onderzoek heeft betrekking op de zelfbeoordeling door de deelnemers van hun gedrag als uitkomstmaat. Dit zou tot een geflatteerde samenhang tussen de onderzochte variabelen kunnen leiden. Weliswaar staat hier tegenover, dat een dergelijke samenhang dan naar verwachting ook in de regressieanalyses naar 
voren had moeten komen, wat niet het geval was, waardoor kan worden aangenomen, dat de ontwikkelde variabelen voldoende op zichzelf staan. Tevens hebben Fishbein en Ajzen (2010) duidelijk kunnen aantonen, dat zelfbeoordeling een goede indicatie is voor het daadwerkelijk gedrag. Een aanvulling van het onderzoek met een toets of praktijkexamen zou in dat verband een positieve bijdrage kunnen hebben op de onderzoeksresultaten. Ook had bijvoorbeeld een 360-gradenfeedback een aanvullend instrument kunnen zijn om het gewenste gedrag in de praktijk te kunnen meten.

Een derde beperking heeft betrekking op de mate van aandacht die de deelnemers hebben ontvangen. Men zou kunnen veronderstellen, dat de deelnemers aan het maatwerkprogramma meer aandacht of feedback hebben ontvangen dan de deelnemers in de standaardgroep en daardoor het effect in grote mate door de factor 'aandacht' zou kunnen zijn beïnvloed (zie paragraaf 2.1). In de praktijk kregen alle deelnemers feedback op hun gedrag. In de standaardaanpak was dat voorzien tijdens oefeningen en in gesprekken met mededeelnemers. Het verschil met het maatwerkprogramma lag met name in het expliciet koppelen van de factoren uit het 'Reasoned Action Model' aan de leerdoelen van de deelnemers en de uitkomsten van de vragenlijst (i.e. het type feedback verschilde, maar de hoeveelheid niet). Door de trainer is aan de deelnemers van beide programma's gemiddeld 1 uur extra uitleg en toelichting per deelnemer gegeven. Tijdens de training is bij het maatwerkprogramma expliciet aandacht geschonken aan het 'Reasoned Action Model'. Het is dus niet aannemelijk, dat de verschillen tussen beide groepen deelnemers veroorzaakt zijn door grote verschillen in de mate van aandacht die zij kregen. Wel is gebleken, dat de training effect heeft gehad en toekomstige interventies veel eerder moeten worden gericht op de transfer en niet op het aanpassen van de training. Verder is bij de trainingsgroep gebleken dat zij met name een betere 'attitude' met betrekking tot de inhoud van de training laat zien. De werkgroep concludeerde, dat het van belang was om het aangeleerde gedrag te blijven stimuleren, vanwege de invloed van 'attitude' op de transfer van de training (Den Ouden, 1997). Naast het belang van de 'attitude' bleek ook de sociale steun van belang voor de transfer van training. Volgens Den Ouden (1997) is sociale steun zelfs een vereiste voor het uitkomen van de gedragsvoornemens. In de praktijk bleek niemand in de organisatie enige steun vanuit de organisatie te ontvangen: men ging gewoon op cursus en dat was het dan. Volgens de 'Reasoned Action Approach' wordt hierdoor de kans op gedragsverandering verkleind.

Een vierde beperking betreft de lage verklaarde variantie bij de vervolgmetingen in deze studie. Zoals eerder aangegeven blijkt slechts de variabele 'attitude' in de tweede meting een statistisch significante invloed te hebben op het daadwerkelijke gedragsvoornemen. Derhalve kan men aannemen dat, naast de deelname aan het maatwerkprogramma, de 'attitude' na de eerste interventie de beste voorspelling geeft voor het gedragsvoornemen. In die zin geeft het meetinstrument op de diverse variabelen uit het 'Reasoned Action Model' geen 'voorspelling van succes'. Een mogelijke verklaring daarvoor is, dat het te veranderen gedrag in het geval van de training in communicatievaardigheden uit diverse deelgedragingen bestond die onvoldoende specifiek waren uitgewerkt. Daardoor was het moeilijk om te voldoen aan Fishbein en Ajzen's criterium waarin 'het doel, de situatie of context, het tijdstip en de plaats' bij de meting van het te vertonen gedrag eenduidig omschreven moeten worden. In de praktijk blijkt communicatiegedrag uit diverse deelgedragingen te bestaan.

Zo bestaat de vaardigheid 'actief luisteren' uit zowel oogcontact, knikken, samenvatten en dergelijke. Fishbein en Ajzen $(1975 ; 2010)$ benadrukken dan ook, dat naarmate de 
omschrijving van het te onderzoeken gedrag beter overeenkomt met bovengenoemde voorwaarden ten opzichte van de gedragsdeterminanten, de voorspellende waarde van dit model toeneemt (Abraham, Sheeran \& Johnston, 1988). In eerdere studies naar bijvoorbeeld het gebruik van handschoenen onder verpleegkundigen (Levin, 1999) en het inleveren van oud papier (Boldero, 1995) zijn beduidend hogere verklaarde varianties gevonden dan in onze studie. Kennelijk heeft de specificiteit van het te onderzoeken gedrag invloed op de onderzoeksuitkomsten en is het relatief moeilijk om complex gedrag eenduidig te verklaren vanuit het 'Reasoned Action Model'. In de vervolgonderzoeken is dan ook veel tijd besteed aan het concretiseren van het beoogde gedrag. In de gehanteerde vragenlijst is dat wel achterwege gebleven.

Een vijfde beperking heeft betrekking op de schaalconstructie. Reeds bij het onderzoek naar de ontwikkeling van het meetinstrument is duidelijk geworden, dat de deelnemers de neiging hebben tot het invullen van een 'neutrale' score. In grafiek 3.1 op pagina 5556 is dat goed te herkennen. Alle scores bevinden zich tussen de 2.9 en 3.9 bij een range van 1-5. De keuze om met een 6-puntsschaal te werken is naast statistische overwegingen ook vanuit de kwalitatieve analyse als positief te beoordelen. Het dwingt de deelnemer tot een keuze en past bij de constructie van de vraagstelling waarin gebruik wordt gemaakt van twee uitersten. Door de toepassing van twee uiterste polen in de antwoordcategorieën van de vragenlijst (goed - slecht) wordt een indicatie gegeven van de mate van de score (hoe goed of hoe slecht iets is). Hoe verder de score van het gemiddelde verwijderd is, hoe sterker/extremer het antwoord. Tevens geeft de standaarddeviatie er een indicatie van, hoe sterk de antwoorden met elkaar overeenkomen. Bij een lage standaarddeviatie kan men ervan uitgaan, dat de deelnemers het redelijk eens zijn met het gegeven gemiddelde antwoord. Met een dergelijk grove analyse laten zich vrij snel de 'extremen' in de antwoorden identificeren. Bij het opstellen van de vragen is in het begin bij enkele antwoordmogelijkheden onvoldoende gelet op het 'neutraal' formuleren van de vraag. Bijvoorbeeld vraag 12 (in bijlage 3) waarin de stelling luidt: 'Ik heb voldoende kennis om aan de training een bijdrage te kunnen leveren' wordt al een beoordeling op zich weergegeven. In latere versies is dit gecorrigeerd door de stellingen neutraal te formuleren (in dit voorbeeld: 'Mijn kennis om aan de training een bijdrage te kunnen leveren is...'). Deels is dit hiaat opgelost door de antwoorden die conform de aanbevelingen van Fishbein en Ajzen (2010) wél dichotoom geformuleerd zijn (in dit voorbeeld: 'voldoende - onvoldoende'). Een nadeel van deze constructie is dat een respondent geen gelegenheid wordt geboden tot een 'neutraal' antwoord, waarin deze aangeeft dat men eigenlijk niet zo goed weet of een bepaald antwoord van toepassing is, dan wel dat men eigenlijk geen uitgesproken mening heeft over het bevraagde aspect. 


\subsection{Conclusies en beperkingen in relatie tot de casestudies}

Om na de ontwikkeling van het meetinstrumentarium een antwoord te kunnen geven op de deelvragen 3 tot en met 5, is de ontwikkelde methode in een aantal casestudies toegepast (zie hoofdstuk 4). In overeenstemming met de uitkomsten van het onderzoek naar de ontwikkeling van het meetinstrumentatrium (hoofdstuk 3) geven ook de uitkomsten van de casestudies een duidelijk beeld van het effect van de uitgevoerde interventies. Deze zijn door onderzoeksdesign, aantal deelnemers en statistische analyses eerder illustratief dan dat er harde conclusies uit kunnen worden getrokken. Er kan worden aangetoond, dat in twee gevallen ondanks doorgevoerde interventies geen verandering heeft plaatsgevonden op de in het meetinstrumentarium omschreven factoren (het onderhoudsbedrijf en de kennisorganisatie in Canada). Alleen in het geval van de kennisorganisatie in China kan voorzichtig worden geconcludeerd, dat de interventie invloed had op de intentie in relatie tot het beoogde gedrag. In eerste instantie lijkt dit teleurstellend. Aan de andere kant bevestigen de uitkomsten de waarnemingen van de betrokken werkgroepleden van het onderhoudsbedrijf, die aangaven dat er weinig veranderde gedurende de doorlooptijd van de interventietrajecten. Tevens ondersteunen de uitkomsten de stelling dat naarmate het gewenste doel duidelijker is omschreven, de interventie meer effect zal hebben. In Canada werden reeds bij de voormeting hoge scores aangetroffen en leek het moeilijk deze nog meer te verbeteren. Wel kon een verschil aangetroffen met betrekking tot de overtuigingen ('beliefs') in de huidige situatie, wat erop duidt dat de betrokken personen het gewenste gedrag als nuttig ervaren en ook daadwerkelijk toepassen. Bij het onderzoek in China was de interventie duidelijk gericht op specifieke gedragingen. Pas op langere termijn en in de dagelijkse praktijk moet blijken of trainen zinvol is en of deze tot effectieve gedragsverandering zal leiden. Hiervoor zijn wel één of meerdere follow-upmetingen noodzakelijk. Bij alle onderzoeken heeft op grond van verschillende overwegingen van de opdrachtgever geen tweede nameting plaatsgevonden waardoor een uitspraak over het effect op langere termijn niet mogelijk is. Een follow-upmeting is derhalve voor de toekomst zeker noodzakelijk. Ronduit funest voor de kracht van de deelonderzoeken is het feit, dat er is verzuimd bij ieder onderzoek opnieuw de betrouwbaarheid en (expert)validiteit van het onderzoeksinstrument te onderzoeken. Hierdoor verliest het onderzoek aan kracht en zijn de uitkomsten eerder een indicatie dan hard bewijs.

Hierdoor onderbouwen de uitkomsten de conclusie van Russ-Erft en Preskill (2005), dat de complexiteit van de dagelijkse werkomgeving, het politieke spel binnen organisaties en de minder systematische manier van het doen van evaluaties, onderzoek in het veld belemmeren. Een meer uniforme en meer gestructureerde aanpak is daarom gewenst (Eseryel, 2002). Bovendien laten de uitkomsten van deze onderzoeken zien, dat de relatie tussen 'intentie' en het daadwerkelijk uit te voeren gedrag niet altijd zo evident is als in het 'Reasoned Action Model' gesuggereerd wordt. Globaal kan worden geconcludeerd, dat de gekozen methode bij de casestudies:

- inzicht verschaft in de toe te passen interventie;

- goed aansluit bij de doelgroep;

- een goede indicator is van het succes van gedragsverandering;

- het effect van interventies zichtbaar en evalueerbaar maakt;

- het meetinstrument ook in andere culturen (taal) goed te gebruiken is;

- impliciet gedrag expliciteert en meetbaar maakt;

- de doelgroep actief bij de verandering betrekt;

- geen uitspraak doet over keuzen van de interventie zelf. 
Bij alle casestudies heeft de gekozen methode duidelijk inzicht in de toe te passen interventies verschaft. De in de 'Reasoned Action Approach' gehanteerde begrippen maken voor zowel voor de onderzoekers als voor de doelgroep inzichtelijk wat er onder het beoogde gedrag werd verstaan en welke drempels een gedragsverandering bemoeilijkten (Ajzen, 2002). Mogelijke interventies gericht op verandering van de 'attitude' hadden bijvoorbeeld betrekking op het inzicht verschaffen in de voordelen van nieuw gedrag en het consequent blijven communiceren van wat dat nieuwe gedrag inhoudt. Ook voor de andere aspecten van het model konden vergelijkbare interventies worden gesuggereerd. Bij het onderzoek binnen het onderhoudsbedrijf is wel sprake van een grote hoeveelheid aan gedragsaspecten; een aandachtspunt dat bij de (latere) andere onderzoeken duidelijk is beperkt door de gedragsvariabelen (uitkomst en intenties) te clusteren. Vooral bij de kennisorganisaties (in China en Canada) was het bespreken en inzichtelijk maken van de gerelateerde gedragsaspecten een eyeopener voor het zittende management. In die zin maakt de 'Reasoned Action Approach' impliciete aannames expliciet, omdat samen met de doelgroep naar passende oplossingen wordt gezocht. Hiermee is de ontwikkelde vragenlijst niet alleen een meetinstrument maar ook een middel om feedback te geven op de stand van zaken in relatie tot een beoogde gedragsverandering. Binnen het onderhoudsbedrijf is de onderzoeker ook 'bedrijfsdokter' genoemd en werd de vragenlijst schertsend als 'de thermometer' aangeduid. Verder biedt 'Reasoned Action Approach' ook een keuze; de organisatie zelf kiest voor oplossingsrichtingen en in welke mate op welke factoren een interventie plaatsvindt. Hiermee draagt de ontwikkelde vragenlijst ook bij aan een efficiënte inzet van mensen en middelen tijdens een gedragsinterventie/training.

Door het systematisch toepassen van de principes van 'Intervention Mapping' wordt een duidelijk omkaderd proces geboden om op een gestructureerde wijze complex gedrag meetbaar te maken, waarbij de begripsvorming maximaal aansluit bij de doelgroep. Door de probleemgeoriënteerde aanpak van 'Intervention Mapping' was de doelgroep bij de uitkomstcriteria betrokken en werd ook optimaal gebruik gemaakt van de aanwezige kennis en oplossingsrichtingen binnen de doelgroep. Er worden duidelijke probleemstellingen geformuleerd en concreet te behalen doelen opgesteld. Ook raakten medewerkers betrokken bij de te volgen strategie en wordt door toepassing van de principes van 'Intervention Mapping' de gekozen aanpak voor een groot deel de verantwoordelijkheid van henzelf. De organisatie wordt gedwongen om vanuit een probleemstelling mogelijke oplossingen te formuleren en zelf te bepalen welke interventies, gegeven de situatie, het meest geschikt zijn. Daarbij is aan de hand van literatuurstudie en reeds in de organisatie aanwezige kennis onderzocht wat elders in vergelijkbare situaties is toegepast.

De conclusie dat het ontwikkelde meetinstrument een goede indicator is voor het succes op gedragsverandering, valt minder eenduidig te bevestigen. Vooral omdat het hierbij om de voorspellende waarde van het 'Reasoned Action Model' gaat, een wens van iedere organisatie om dat wel te kunnen doen. Juist omdat gedrag een complex gegeven is en randvoorwaarden grondig kunnen wijzigen, wordt het bepalen van succes een nagenoeg onmogelijke zaak. Een feit dat ook door Jaccard (2012) wordt aangegeven. Hij pleit dan ook voor een aanpak waarin meer rekening wordt gehouden met de overtuigingen van de deelnemers ('beliefs'), het 'split second decision'-effect waarbij personen redelijk onbewust in extreem korte tijd een beslissing nemen, de context en 
multioptionele keuzes waarin niet altijd een duidelijke juiste keuze aanwezig is. 'Intervention Mapping' kan daarbij goed ondersteunen, omdat er per situatie en doelgroep een analyse wordt gemaakt van het probleem en de daarbij behorende variabelen. Met de gevonden resultaten konden concrete aanbevelingen worden geformuleerd die door de werkgroep naar specifieke interventies zijn vertaald. In die zin kan er vooral een redelijke indicatie van worden gegeven, hoe veel tijd en energie in een verandertraject moeten worden geïnvesteerd.

Fishbein en Ajzen (2010) hebben ook kritiek gekregen op de voorspellende waarde van hun model. Daartegenover staan talrijke onderzoeken die juist aantonen dat het 'Reasoned Action Model' voldoende voorspellende waarde heeft in relatie tot het beoogde gedrag. In dit proefschrift blijft de verklaring van succesvolle gedragsverandering zeer beperkt. Het was in deze context ook minder van belang, omdat er vooral is gekeken naar het meten van de procesoptimalisatie van (gedrags)interventies en dus niet naar de voorspellende waarde van het 'Reasoned Action Model'. Voor de oorspronkelijke doelstelling van dit onderzoek is dat ook minder relevant, omdat de aanname is, dat het model een uitstekend meetinstrument is om gedragsverandering te meten en niet te voorspellen. Het is te vergelijken met een thermometer: het geeft de temperatuur en het verloop daarvan geeft weer hoe de behandeling aanslaat en geeft een indicatie over het verdere verloop. Bovendien wijst Ajzen (2014) op het feit dat naarmate het gedrag duidelijker omschreven is in de termen van 'activiteit', 'doel', 'context' en 'tijd' de waarde van het model toeneemt.

Wat de effectiviteit en procesoptimalisatie betreft geven de casestudies weinig uitsluitsel, omdat een follow-upmeting bij alle onderzoeken is uitgebleven. Alleen bij het onderzoek ter ontwikkeling van het meetinstrument is hiervoor een positieve aanwijzing gevonden. Door een follow-upmeting had de transfer naar de praktijk nadrukkelijker in het onderzoek kunnen worden opgenomen. Nu bestaat het gevaar dat er sprake is van een 'positief of negatief effect' zonder dat er gedragsverandering in de praktijk heeft plaatsgevonden. Niettemin geeft een follow-upmeting na een interventie niet direct inzicht in het verloop van het veranderingsproces en biedt het geen mogelijkheden om dit tussentijds bij te sturen. De aangetroffen uitkomsten sluiten wel enigszins aan bij het meer kwalitatieve onderzoek van Poiesz (1999), die eveneens vond, dat factoren als 'gebrek aan motivatie tot veranderen' en 'gebrek aan capaciteiten dan wel gelegenheid om de veranderingen door te voeren' een negatief effect hadden op de mate van gedragsverandering. Vooral de wisseling van de 'aanjagers' van de beoogde veranderstrategie had mogelijk invloed op de uitkomsten van het onderzoek. Organisaties nemen wat dat betreft te weinig tijd om een probleem goed te analyseren en een interventie te evalueren. Bovendien blijven beslissers (managers) tegenwoordig zo kort in hun functie dat zij eerder de neiging lijken te hebben geen verantwoordelijkheid te willen nemen voor een gedragsverandering die veel tijd kost. In een dergelijke context zijn de aangetroffen resultaten (of het gebrek daaraan) mogelijk niet uitsluitend te wijten aan de gehanteerde relatief beperkte onderzoeksopzet, maar ook aan de mogelijkheden die een onderzoeker in de praktijk worden geboden, een aanname die verder onderzoek verdient. Een aanwijzing hiervoor is, dat door de organisaties in alle gevallen nadrukkelijk is aangegeven geen verband op individueel niveau tussen voor- en nameting te willen leggen. Statistisch gezien was dit aanlokkelijker geweest en is geprobeerd op basis van de algemene gegevens (leeftijd, geslacht, opleiding, etc.) een verband te kunnen leggen. Echter, de deelnemers zelf hebben deze persoonlijke gegevens onzorgvuldig ingevuld en daarmee zou de groepsomvang nog geringer zijn geweest. Een ver- 
dere beperking betreft de geringe steekproefomvang en het ontbreken van een controlegroep. Aan de steekproefomvang kan weinig worden veranderd. Voor het ontbreken van een controlegroep is in het vervolgonderzoek naar de toepassing van IRS een redelijk en praktisch haalbaar alternatief gevonden.

Een belangrijk voordeel van de gehanteerde methodiek, (de 'Reasoned Action Approach' gecombineerd met 'Intervention Mapping'), ten opzichte van andere methodes is dat de focus komt te liggen op het beoogde resultaat en niet op het toepassen van één bepaalde interventietechniek zoals Gerrichhauzen, Kampermann en Kluytmans (1996) dat doen; veeleer worden knelpunten geïdentificeerd, veranderrichtingen aangegeven en wordt de effectiviteit van de gekozen interventie meetbaar gemaakt. Voor adviseurs en gedragsveranderaars is dat een aanlokkelijk perspectief: geen discussies en stammenstrijd meer over de gekozen veranderconcepten en diverse interventietechnieken, maar een gestructureerde en op de doelgroep gerichte werkwijze om gedragsverandering te sturen en te evalueren. De 'Reasoned Action Approach' is daarbij een hulpmiddel om mogelijke oplossingsrichtingen te concretiseren en de verandering te meten. Als interventie-instrument is het niet bedoeld. Er wordt veel meer aangegeven, hoe interventies ontwikkeld kunnen worden en hoe het effect van de gekozen interventies gemeten kan worden. 'Intervention Mapping' is dus een ondersteunend middel om interventies voor gedragsverandering richting te geven en om het effect daarvan te meten.

Een laatste en belangrijk kritiekpunt is dat bij de deelonderzoeken de onderzoeker zelf als adviseur of trainer is opgetreden. Hierdoor zouden warnemingen kunnen worden beïnvloed en kan het effect hebben op de waargenomen uitkomsten. Daartegenover staat dat veel onderzoeken in de gezondheidszorg (bijvoorbeeld onderzoeken naar effecten van therapievormen) ook niet 'dubbelblind' worden uitgevoerd. In dit onderzoek is dit mogelijke negatieve effect slechts voor een deel van toepassing omdat bijvoorbeeld bij de eerste casestudie de organisatie zelf verantwoordelijk was voor de interventies. Bij de andere twee casestudies en bij het onderzoek naar de ontwikkeling van het instrument is altijd met twee of meer personen gewerkt waardoor een directe invloed door de onderzoeker zelf verkleind werd. Tevens zijn er ook kritische kanttekeningen met betrekking tot dubbelblind onderzoek in de praktijk. Van der Steen (2003) benadrukt dan ook de kracht van casuïstiek als bewijsmateriaal voor theoretische concepten. In dit onderzoek waren dan ook kosten een belangrijke drijfveer van de opdrachtgever om het onderzoeksdesign zo eenvoudig mogelijk te houden. Tevens waren de onderzoeksgroepen relatief klein, waardoor toepassing van een grote hoeveelheid adviseurs/trainers al helemaal niet noodzakelijk was. Dit spanningsveld komt men bij organisaties vaak tegen en er is dan ook getracht de statistische verwerking en analyse eenvoudig en integer te laten verlopen door gebruik te maken van interne adviseurs van de opdrachtgever.

\subsection{Conclusies en beperkingen in relatie tot het onderzoek zonder contro- legroep}

Een van de beperkingen bij de toepassing van het ontwikkelde instrumentarium is, dat er geen gebruik is gemaakt van een controlegroep, een verschijnsel dat in vergelijkbare 
gevallen veelvuldig voorkomt. Het is immers vanuit de opdrachtgever niet verantwoord een deel van de in aanmerking komende werknemers wel aan een gedragsinterventie deel te laten nemen en een ander deel niet. Daarnaast zouden door het toch al kleine aantal deelnemers de groepen dermate klein worden, dat een statistische analyse onmogelijk is. Derhalve is ter aanvulling op dit praktische probleem de op het 'Reasoned Action Model' gebaseerde vragenlijst aangevuld met de toepassing van de 'Internal Referencing Strategy' (IRS). De veronderstelling is dat deze als 'controlegroep' fungeert en dat na een interventie geen verandering daarop heeft plaatsgevonden. De in dit deelonderzoek aangetroffen resultaten maken dit effect aan de hand van een uitgevoerde gedragstraining inzichtelijk. De aanname dat de experimentgroep op de irrelevante schaal geen groei zou laten zien en op de andere schalen (in dat geval gericht op 'attitude', 'ervaren norm') wel, wordt door de resultaten voor een groot deel bevestigd. De aanname bij de controlegroep dat deze op geen enkele schaal een significante verandering over de tijd zou laten zien, bleek correct. De controlegroep heeft - zoals verwacht geen groei laten zien op alle schalen en de irrelevante schaal is - zoals verwacht - bij beide groepen redelijk stabiel gebleven. Hieruit kan geconcludeerd worden, dat de verandering die bij de interventiegroep optrad aan de training toegeschreven kan worden. Bovendien maken de factoren van het 'Reasoned Action Model' ook inzichtelijk op welke aspecten de training het meest invloed heeft gehad om de 'gedragsintentie' te verhogen. Naast het gemeten effect laat het onderzoek tevens zien, dat de irrelevante schaal (IRS-schaal) daadwerkelijk stabiel blijft, hetgeen suggereert dat dit design in de toekomst zonder controlegroep kan worden uitgevoerd. Wel zou men kunnen veronderstellen, dat toepassing van zelfbeoordelingen tot subjectieve en sociale wenselijke antwoorden kan leiden. Wanneer er sprake was geweest van een dergelijke beïnvloeding van de resultaten, had dit naar voren moeten komen op de irrelevante schaal, maar dit was niet het geval, waardoor deze aanname kan worden verworpen.

Ook dit (deel)onderzoek kent een aantal beperkingen. Zo kan door het ontbreken van een follow-upmeting geen uitspraak worden gedaan over de transfer van de interventie (Robson, 2002). Op verzoek van de opdrachtgever was deze uitgesteld, omdat het opleidingsaanbod binnen de organisatie grondig is geëvalueerd. Later is de training geheel uit het opleidingsaanbod gehaald, waardoor een follow-upmeting niet meer als noodzakelijk is ervaren. Hoewel met de toepassing van de 'Internal Referencing Strategy' (IRS) getracht is het effect van de interventie goed inzichtelijk te maken, blijft een follow-upmeting noodzakelijk, temeer omdat van effect pas sprake is als de onderzoeksuitkomsten daadwerkelijk stand houden door de tijd heen (Robson, 2002). Verder beperkt het onderzoek zich tot de verandering bij de deelnemer, waardoor geen duidelijke uitspraak gedaan kan worden over de verandering in de organisatie (Spritzer, 2005). Een ander aandachtspunt is dat het gebruik van de irrelevante schaal niet altijd valide is (Garson, 2008). De inhoud van een dergelijke schaal moet dusdanig dicht bij het onderzoeksonderwerp liggen, dat de schaal niet herkend wordt als zijnde irrelevant. Dit verhoogt echter het risico dat een interventie ook de score van de irrelevante schaal beïnvloedt. Ook hierbij bieden de gekozen aanpak en de toepassing van 'Intervention Mapping' uitkomst. Door de beschreven methode systematisch toe te passen en de doelgroep bij het ontwerp van het meetinstrument te betrekken, wordt dit risico op herkenbaar afwijkende schaalinhoud geminimaliseerd. Verder is dit deelonderzoek uitgevoerd met een relatief kleine steekproef $(N=32)$. Zoals eerder beschreven, kan dit leiden tot systematische meetfouten en oneigenlijke resultaten.

Om in te spelen op dit risico is bij dit deelonderzoek wel gebruik gemaakt van validatie 
en betrouwbaarheidsanalyse van de vragenlijst. Daarnaast is in relatie tot de schaalconstructie getoetst of Cronbach's $\alpha$ voldoende was en is gebruik gemaakt van een gepaarde t-toets. Desondanks blijft het aan te bevelen om dit onderzoek in een bredere setting met meer deelnemers en een follow-up meting uit te voeren. De uitkomsten maken duidelijk, dat het gebruik van een controlegroep niet altijd noodzakelijk is om het effect van gedragsinterventies te meten. De 'Internal Referencing Strategy' (IRS) lijkt daarmee een goede aanvulling op het instrumentarium om meer inzicht te krijgen in het meten van gedragsverandering, wat organisaties helpt om interventies gerichter in te zetten.

\subsection{Aanbevelingen voor verder onderzoek en toepassing in de praktijk}

De resultaten en beperkingen van de uitgevoerde onderzoeken en het gekozen onderzoeksdesign zijn in de voorafgaande paragrafen besproken en van de nodige kanttekeningen voorzien. Het blijft een moeilijke opgave om in de praktijk goed gecontroleerd onderzoek uit te kunnen voeren. Desondanks heeft dit onderzoek inzichtelijk gemaakt, dat succesvolle en beproefde modellen binnen diverse disciplines een toegevoegde waarde hebben. Daar waar het om gedragsverandering gaat lijken de 'Reasoned Action Approach' (Ajzen, 1991; Fishbein \& Ajzen, 2010) in combinatie met een aanpak gebaseerd op 'Intervention Mapping' (Bartholomew et al., 2006; Schaalma et al., 2001) een zinvolle basis om gedrag te meten en effectief en op langere termijn te beïnvloeden. Voor toekomstig onderzoek naar de effectiviteit van gedragsinterventies kunnen de ontwikkelde vragenlijst en methode als een universeel meetinstrument en hulpmiddel dienen bij het bepalen van de meest optimale oplossing. Door het systematisch gebruik van het ontwikkelde meetinstrumentarium en de toepassing van steeds dezelfde methode zijn onderzoeken beter met elkaar te vergelijken. Ook wordt voor onderzoeker en deelnemer duidelijker wat uiteindelijk bijdraagt tot het verder ontwikkelen van de effectiviteit van gedragsinterventies.

\subsubsection{Aanbevelingen voor toekomstig onderzoek}

Vanuit wetenschappelijk oogpunt laten zich voor toekomstig onderzoek een aantal aanbevelingen formuleren.

Ten eerste is het noodzakelijk dat er een (of meerdere) follow-upmetingen worden verricht. Om gefundeerde uitspraken te kunnen doen over het resultaat van een interventie of de relatie tussen de factoren uit het 'Reasoned Action Model' en het beoogde resultaat blijft een opzet noodzakelijk waarbij voor de inzet van de ontwikkelde vragenlijst sprake is van minimaal een voor-, na- en follow-upmeting.

Ten tweede zou de ontwikkelde methode voor verdere toepassing in de praktijk nog een keer onder vergelijkbare omstandigheden met dezelfde interventie in een andere context (type organisatie en land) getoetst moeten worden. In het gepresenteerde onderzoek was sprake van onderzoeken in verschillende organisaties en met diverse probleemstellingen en interventies. Dit vergroot de kans op 'toevalsfouten' waardoor de onderzoeken alsnog niet goed met elkaar kunnen worden vergeleken. Door het gebruik van deze methode met steeds dezelfde interventiemethode (te denken valt aan effectieve communicatie) in een andere context wordt de kwaliteit van het meetinstrument verhoogd. 
Ten derde zou de vragenlijst zo moeten worden aangepast, dat de mogelijkheid op een 'weet niet'-antwoord kan worden geboden. Eerder in dit proefschrift wordt het gebruik van een vraagteken gesuggereerd, wat de kwaliteit van het instrument ten goede zou komen.

Een vierde aanbeveling is om meer tijd besteden aan het formuleren van goed ingekaderde resultaten volgens de aanbevelingen van Fishbein en Ajzen (2010), waarbij de 'actie' zelf, het 'doel', de 'context' en de 'tijd' in meetbare omschrijvingen worden vastgelegd. In het gepresenteerde onderzoek is omwille van tijd en hanteerbaarheid van het meetinstrumentarium gekozen voor groepsbijeenkomsten waarin deze aspecten zijn besproken (bijvoorbeeld in paragraaf 4.4) en is genoegen genomen met bredere begrippen.

Ten vijfde zou een literatuurstudie naar interventies gekoppeld aan de in de 'Reasoned Action Approach' beschreven factoren kunnen plaatsvinden. In de uitgevoerde onderzoeken lag de nadruk op het probleem en interventies/oplossingen die daarmee verband hielden. Weliswaar zijn per factor oplossingsrichtingen geformuleerd, waarbij de wetenschappelijke onderbouwing daarvan onvoldoende is getoetst. Fishbein en Ajzen (2010) bespreken hoe de determinanten 'attitude', 'ervaren norm' en 'ervaren controle' kunnen worden gemeten, maar juist niet welke interventies zouden moeten worden gekozen, als er een lage score op een van deze factoren wordt aangetroffen. Een handzaam overzicht van welke algemene interventies een positieve invloed uitoefenen, zou een goede aanvulling zijn. Een voorbeeld is het onderzoek bij het onderhoudsbedrijf (paragraaf 5.2). Daarbij heeft de projectgroep aangenomen, dat voorlichting, gesprekken in teams en tastbaar maken van de voordelen, een positief effect op de factor 'attitude' zouden hebben.

Voor een duidelijke bepaling van de maatschappelijke waarde zou tenslotte de ROI ('Return of Investment') moeten worden bepaald. Zo zou een opleidingsinstituut dat een grote hoeveelheid trainingen aanbiedt, het effect van de ontwikkelde methode ten opzichte van een standaardopleiding moeten onderzoeken. Pas dan wordt duidelijk of de extra inspanning door toepassing van deze methode opweegt tegen de meerwaarde daarvan in de praktijk. Een meer longitudinaal onderzoek is de meest geschikte oplossing om een verband met de economische waarde kunnen leggen.

\subsubsection{Aanbevelingen voor praktische toepassing}

Op basis van de aangetroffen resultaten kan ook een aantal aanbevelingen voor de toepassing van deze methode geformuleerd worden.

Ten eerste: Maatwerk is beter dan confectie. Vooral bij de ontwikkeling van de vragenlijst is duidelijk geworden dat een maatwerkprogramma met concrete terugkoppeling over de voortgang duidelijk betere resultaten oplevert dan een standaardprogramma. Zo zou een intake waarin duidelijke en meetbare resultaten worden vastgelegd, de standaard voor iedere (gedrags)interventie moeten worden. Maar ook verandertrajecten zouden minder instrumenteel moeten worden ingevoerd. Nog te vaak wordt weinig rekening gehouden met belemmerende en/of bevorderende factoren bij de doelgroep. Dit geldt in het bijzonder voor situaties waarin naast kennisoverdracht en het aanleren van deelvaardigheden het programma ook erop gericht is om de deelnemer inzicht verschaffen in diens invloed op de transfer naar de praktijk. De deelnemer wordt daarmee 
zelf verantwoordelijk voor de beoogde eigen verandering. Deze bevindingen zijn in overeenstemming met de aanbevelingen van Schaalma (1993) en Schaalma et al. (2001). Zowel de 'Reasoned Action Approach' als 'Intervention Mapping' zijn bruikbare middelen om maatwerkinterventies te ontwikkelen. Een goed voorbeeld uit de eigen waarneming is 'Het Nieuwe Werken' dat bij veel (semi)overheidsinstanties haar intrede doet en wat daarbij instrumenteel wordt toegepast zonder rekening te houden met bijvoorbeeld cultuur, managementstijl en psychologische aspecten. Volgens Bijl (2007) is 'Het Nieuwe Werken' een 'visie waarbij recente ontwikkelingen in de informatietechnologie als aanjager gelden voor een betere inrichting en bestuur van het kenniswerk. Het gaat om vernieuwing van de fysieke werkplek, de organisatiestructuur en -cultuur, de managementstijl en niet te vergeten de mentaliteit van de kenniswerker en zijn manager'. Daarin staan het experimenteren met nieuwe vormen van samenwerking, maar ook nieuwe manieren van leidinggeven - minder hiërarchie, meer eigen verantwoordelijkheid en meer overlaten aan eigen creativiteit - voorop. Technologie is daarin een hulpmiddel, dat deze visie moet ondersteunen. In de praktijk ziet het er echter heel anders uit, omdat rekening moet worden gehouden met onder andere de aanwezige cultuur en eerder beschreven menselijke aspecten. De beoogde doelstelling is vooral een besparing voor de organisatie door vermindering van de vierkante meters per medewerker. Door het weghalen van muren, gebruik van frisse kleuren en leuke kamerbenamingen in plaats van kamernummers, en het uitdelen van mobiele apparatuur (laptop en smartphone) hoopt men deze nieuwe vorm van samenwerking te realiseren. In de praktijk blijven mensen meer thuis, voelt men zich minder betrokken bij het werk en wordt het werken in grote ruimtes waarin de eigen werkplek niet meer zeker is, als stressverhogend ervaren. Het verschil tussen een ZZP'er en een collega of medewerker van een organisatie is onduidelijk geworden, waardoor binding en verbinding met de organisatie waartoe men behoort, kunnen afnemen. Een taak die het management dan op zich zou moeten nemen. Maar vaak stranden goede voornemens waaronder het aspect van cultuurverandering, in instrumentele oplossingen. De in dit proefschrift ontwikkelde methode zou hier bij uitstek een hulpmiddel zijn om ook de meer kwalitatieve doelstellingen van een veranderproces te monitoren en te sturen.

Ten tweede: Meten is weten. Bij alle (gedrags)interventies zou bij het ontwerp en de toepassing van gedragsinterventies/trainingen het gewenste gedrag zo 'meetbaar' mogelijk gemaakt moeten worden. Gedurende het onderzoek is gebleken dat de oorspronkelijk ontwikkelde vragenlijst op een aantal vragen onvoldoende specifiek was. Pas bij de latere onderzoeken is dat verbeterd. Ajzen zelf geeft hiervoor praktische handvatten (Ajzen, 2002; Fishbein \& Ajzen, 2010). Ook is aan te bevelen om gebruik te maken van een 6-puntsschaal. Uit dit onderzoek bleek dat deelnemers neigen naar het invullen van een gemiddelde score en een 6-puntsschaal maakt dit minder mogelijk door een uitspraak af te dwingen. Bovendien kan door een 6-puntsschaal duidelijk worden aangegeven waar de knelpunten liggen. Daarbij moet wel de mogelijkheid voor een 'ik weet het niet'-antwoord worden geboden.

Ten derde: Leer van anderen. Nog al te vaak wordt bij interventies vanuit een bepaald concept of bepaalde methode gedacht en niet vanuit een probleemstelling en de reeds aanwezige kennis daarover. Door samen met de doelgroep naar 'best practices' te zoeken en deze op de eigen situatie toe te passen, wordt een doeltreffend (trainings)programma ontwikkeld. Voorts zou bij het ontwerp van trainingen ook actief naar 
randvoorwaarden voor de toepassing van de aangeleerde kennis en vaardigheden in de praktijk moeten worden gezocht. Vooral uit het onderzoek naar de toepassing van IRS (hoofdstuk 5) bleek dat deelnemers de training nuttig en leerzaam vonden maar het geleerde niet direct in de praktijk konden toepassen. Tevens is er door de eigen leidinggevende onvoldoende aandacht aan geschonken hoe de deelnemers het geleerde in de praktijk zouden kunnen toepassen, waardoor men vraagtekens kan stellen bij het nut van de gevolgde cursus.

En dit is de vierde aanbeveling: Houd de tijd tussen leerinterventie en toepassing in de praktijk zo kort mogelijk. Vooral uit het deelonderzoek naar de ontwikkeling van het meetinstrumentarium (hoofdstuk 3 ) is een lange-termijneffect (na 3 maanden) aangetroffen door bewust aan de deelnemer terugkoppeling te geven over diens voortgang in de training en een link te leggen met de praktijk. Ook is voor de drie factoren uit het 'Reasoned Action Model' en de aangetroffen barrières gericht naar oplossingsrichtingen gezocht die aansloten bij de individuele situatie. Hiermee wordt de transfer (Kirkpatrick \& Kirkpatrick, 2006) en daarmee het rendement van een interventie verhoogd.

Een vijfde aanbeveling: Zorg voor 'continuïteit' van het (top)management en/of de initiatiefnemers. Al te vaak wordt continuiteit of verantwoordelijkheid voor de ontwikkeling van personeel door het (top)management 'afgekocht' door een extern bureau of adviseur in te schakelen. Men moet beseffen dat gedragsverandering ook tijd kost van degene die verantwoordelijk is voor het proces en de randvoorwaarden. Bij alle praktijkonderzoeken waarin het ontwikkelde concept is toegepast, zijn het topmanagement en/of de initiatiefnemers (vroegtijdig) vertrokken, waardoor een follow-upmeting onmogelijk geworden was. Hierdoor was het niet alleen lastig een lange-termijneffect te meten, maar is ook de mogelijkheid ontnomen om van de toegepaste interventie te leren en daarmee opnieuw verbeterpunten aan te brengen. Dit is immers de laatste fase van het 'Intervention Mapping' proces. Het mag een beetje pathetisch klinken, maar in de huidige tijd lijkt het bijna de regel te zijn geworden om initiatieven te ontwikkelen zonder de gevolgen daarvan te evalueren of zelf te ondergaan. Door verandering van carrière of gedwongen door tegenvallende verwachtingen kan het topmanagement in de huidige tijd weinig leren van de doorgevoerde interventies. Ook zou er meer tijd moeten worden genomen voor de borging van de veranderdoelstelling in de organisatie en de samenstelling van een groep personen die symbool staan voor de verandering. Door zoveel mogelijk personen te betrekken bij de ontwikkeling en uitwerking van een beoogde verandering is de kans kleiner dat een ingeslagen verandering tot stilstand komt bij het vertrek van het management. Kotter (1996) noemt dit de 'winnende coalitie'. Zorg ervoor dat de rol van 'aanjager' breed in de organisatie is belegd.

De zesde aanbeveling betreft het consequent toepassen van dezelfde methode, systematiek en meetinstrumentarium. De gepresenteerde onderzoeken verschillen deels in aanpak en constructie van de vragenlijst. Ondanks wijzigingen van theorieën en modellen blijft het in de wetenschap in relatie tot effectonderzoek noodzakelijk om longitudinaal onderzoek in verschillende settingen uit te voeren, een aanbeveling die door de snelheid en resultaatgerichtheid van de huidige tijd in menige organisatie vaak moeilijk te realiseren valt. 
Ten slotte: Blijf uitproberen. Door een gewenste verandering niet alleen te meten, maar ook te evalueren, is permanente procesverbetering gegarandeerd. Te vaak wordt na een tijd een bepaalde aanpak te hebben gevolgd naar een andere oplossing (hype) gegrepen zonder voldoende van het voorafgaande of van andere disciplines te hebben geleerd. De cynische adviseur spreekt ook van het 'slinger-effect' of een cyclisch proces, waarmee wordt bedoeld, dat huidige interventies morgen al weer in precies de tegenovergestelde richting kunnen sturen. In dat verband is 'Intervention Mapping' het middel bij uitstek om een bij de situatie en de doelgroep passende leerstrategie te ontwerpen en het effect daarvan te meten. Organisaties, deelnemers en aanbieders van trainingen zouden er baat bij hebben voor iedere interventie en/of training een antwoord te formuleren op de uit 'Intervention Mapping' voortvloeiende vragen:

1. Wat is het probleem en daarmee het doel van de training?

2. Hoe kunnen de effecten gemeten worden?

3. Welke interventiestrategieën/oplossingen zijn al bekend?

4. Welke barrières kunnen deelnemers tegen komen?

5. Hoe moet de transfer naar de praktijk gerealiseerd worden?

6. Wat kan iedereen van het gehele proces leren?

Hierdoor is tevens de kans groter dat de binnen verschillende onderzoeksterreinen aanwezige kennis en informatie benut en in een bredere context toegepast wordt. Toekomstig onderzoek zou zich dan ook veel meer moeten richten op de integratie van de diverse methoden dan op diversificatie daarvan. 


\section{Bijlagen}




\section{Bijlage 1: Vooropdracht}

\section{Voorbereidingsopdracht Training Effectieve Communicatie}

Opleidingscode

Naam deelnemer

Functie

Bedrijfsonderdeel

$U$ gaat binnenkort deelnemen aan de training Effectieve Communicatie.

Wilt $u$ ter voorbereiding van de training de volgende vragen beantwoorden en het formulier in de bijgevoegde envelop opsturen naar het opleidingsinstituut.

Met deze informatie kan de trainer zich voorbereiden op de specifieke situatie van de deelnemers.

\section{Algemeen}

1. Wat zijn uw belangrijkste taken?

2. In welke situaties in uw werk is communicatie vooral belangrijk ?

\section{Specifiek}

3. Kunt $u$ een concrete typering geven van uw sterke kant met betrekking tot het communiceren met mensen en in welke situaties merkt $u$ dit vooral?

4. Wilt u een concrete situatie of gebeurtenis beschrijven waarin $u$ het lastig vindt om met mensen te communiceren.

5. Wat wilt u in uw communicatieve gedrag sterker maken/verbeteren:

- naar uw eigen mening:

- naar de mening van uw leidinggevende:

6. Welke leerdoelen wilt $u$ in de training realiseren:

1.

2.

3. 


\section{Bijlage 2: Semigestructureerd interview}

\begin{tabular}{|c|c|}
\hline Effect / Resultaat & $\begin{array}{ll}\text { Gebruikt hij/zij nu een van de volgende vaardigheden? } \\
\text { - } & \text { Houding } \\
\text { - } & \text { Actief luisteren } \\
\text { - } & \text { Roos van Leary } \\
\text { - } & \text { Assertief gedrag } \\
\text { - } & \text { RET } \\
\text { - } & \text { Heedback geven } \\
\text { - } & \text { Effectief vergaderen } \\
- & \text { andere.... } \\
- & \text { Gebruikt ander gedrag af en toe, consistent. } \\
- & \text { Bespreekt hij/zij het gedrag met anderen? } \\
- & \text { Hoe vaak gebruik je ander gedrag? } \\
- & \text { Gebruikt ander gedrag al geruime tijd. } \\
- & \text { Hoe voelde je nadat je ander gedrag hebt toegepast? } \\
- & \text { Hoe ga je om met de negatieve aspecten van ander gedrag (wanneer aanwe- } \\
& \text { zig)? }\end{array}$ \\
\hline Attitude & $\begin{array}{l}\text { - } \quad \text { Wat waren de redenen om voor ander gedrag te kiezen? } \\
\text { - } \quad \text { Wat zijn jouw redenen om effectief gedrag te blijven gebruiken? } \\
\text { - } \quad \text { Waarom vindt je dat je ander gedrag moet gebruiken? } \\
\text { - } \quad \text { Heeft hij /zij de beslissing zelf genomen om aan de cursus deel te nemen? } \\
\text { ken? } \\
\text { - } \quad \text { Wat voor gevoelens gaf dit? } \\
\text { - } \quad \text { En bij iemand die je niet (goed) kende? } \\
\text { - } \quad \text { Wat voor consequenties heeft hij/zij verbonden aan het bewust zijn van } \\
\text { - } \quad \text { Weigen gedragsaspecten? }\end{array}$ \\
\hline Drempels & $\begin{array}{l}\text { - Waren/ Zijn er mogelijke barrières die mogelijk ander gedrag in de weg zou- } \\
\text { den kunnen staan? } \\
\text { - Denk hierbij bijvoorbeeld aan: het tijdig beschikbaar hebben van randvoor- } \\
\text { waarden, het kunnen bespreken van ander gedrag etc. } \\
\text { - Zijn er personen en/of middelen in je directe werkomgeving die het je moei- } \\
\text { lijker maken effectief gedrag toe te kunnen passen? } \\
\text { - Zijn er personen en/of middelen in je directe werkomgeving die het je ge- } \\
\text { makkelijker maken effectief gedrag toe te kunnen passen? }\end{array}$ \\
\hline
\end{tabular}




\begin{tabular}{|c|c|}
\hline Randvoorwaarden & $\begin{array}{l}\text { - Wat voor manieren / randvoorwaarden heb je om ander gedrag toe te kun- } \\
\text { - } \quad \text { Hoe maaksen? } \\
\text { - Hoe zorg je er voor dat je de randvoorwaarden op het juiste moment aanwe- } \\
\text { zig hebt? }\end{array}$ \\
\hline Ervaren controle & $\begin{array}{ll}\text { - } & \text { Heb je specifieke trucs om effectief te communiceren? } \\
\text { - } & \text { Wat doe je als iemand niet meewerkt (geen succes)? } \\
\text { - } & \text { Hoe ga je om met situaties waarin de ander niet mee wil werken? } \\
\text { - } \quad \text { Heb je wellicht specifieke trucjes die het je gemakkelijker maken? } \\
\text { - } \quad \text { In welke situaties gaat het wel eens mis, en wat doe je dan om te zorgen dat } \\
\text { het volgende keer wel goed gaat? } \\
\text { - } \quad \text { Hoe voel jij je nadat je ander gedrag hebt toegepast? Opgelucht? } \\
\text { - Beloon je jezelf voor het gebruiken van ander gedrag. Hoe denk je er voor te } \\
\quad \text { kunnen zorgen dat je ander gedrag blijft gebruiken? }\end{array}$ \\
\hline Ervaren norm & $\begin{array}{l}\text { - Waren er mensen in je omgeving die positief stonden tegenover je beslissing } \\
\text { - } \quad \text { Voel je je verantwoordelijk voor anderen. Waarom? } \\
\text { - } \quad \text { Hoe bespreek je dat je ander gedrag wilt gebruiken met anderen? } \\
\text { - } \quad \text { Wat vinden anderen daarvan? } \\
\text { - } \quad \text { Zijn er anderen in je omgeving die vonden dat je ander gedrag moest gebrui- } \\
\text { ken. Wie en waarom? } \\
\text { - Wat is de mening van.... over effectief communiceren? } \\
\text { - } \quad \text { Chef? } \\
\text { - Collega? } \\
\text { - Partner / omgeving? } \\
\text { - } \quad \text { Voel jij je door hen gesteund? } \\
\text { - Zijn er situaties waarin je effectief gedrag met anderen moeilijker vindt? } \\
\text { Denk aan groepsomvang, je voelt je ziek, de ander reageert agressief, er is } \\
\text { geen prettige gemakkelijke omgeving, de ander heeft meer macht, e.d. } \\
\text { Hoe ga je met die situaties om? Probeer je dit soort situaties te vermijden, en } \\
\text { hoe dan? Wanneer dan toch in die situatie, heb je bepaalde manieren om } \\
\text { toch nog een draai aan de situatie te geven zodat je in ieder geval GEEN met } \\
\text { een goed gevoel de situatie doorstaat? }\end{array}$ \\
\hline
\end{tabular}




\section{Bijlage 3: Definitieve vragenlijst}

\section{Geachte deelnemer,}

Deze vragenlijst dient als instrument om de vraag te beantwoorden welk effect de training Effectieve Communicatie (EC) heeft op het dagelijkse werk. Deze vraag kan met verschillende factoren en omstandigheden samenhangen waardoor een duidelijk antwoord hierop niet gemakkelijk kan worden gegeven.

Voor een goede analyse en aanbevelingen is het wel noodzakelijk om een paar privé / persoonlijke gegevens ter beschikking te hebben.

\section{Belangrijk daarbij is dat deze gegevens enkel en alleen door de onderzoeker verwerkt zullen} worden.

De anonimiteit en vertrouwelijkheid wordt daardoor gewaarborgd. In de rapportage aan de werkgroep zullen dan ook geen cijfers genoemd worden die met één enkele persoon in verband zouden kunnen worden gebracht.

Mocht u nog vragen hebben dan kunt $u$ altijd rechtstreeks contact opnemen met de heer Michael Rauner, telefonisch bereikbaar op (06) 53667878.

Er volgen nu enkele instructies voor het invullen van de vragenlijst:

Er worden twee typen vragen gesteld: 'meerkeuzevragen' en 'open vragen'. Hieronder volgen enkele voorbeelden van deze vragen.

\section{'Meerkeuzevragen'}

De meerkeuzevragen kunt u beantwoorden door één hokje aan te kruisen. Een voorbeeld:

Vraag: Hoe duidelijk vond u deze inleiding?

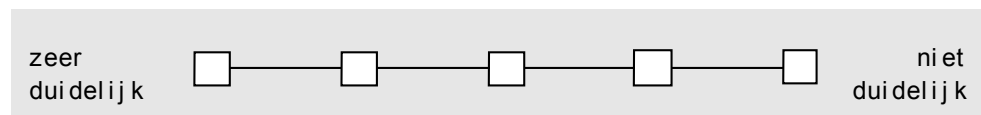

Let op!!! Bij iedere meerkeuzevraag mag u slechts één hokje aankruisen.

Indien u meerdere hokjes zou aankruisen, gaat uw antwoord bij de verdere verwerking verloren. 


\section{'Open vragen'}

Bij 'open vragen' kunt u uw antwoord in het vak daaronder schrijven. Een voorbeeld:

Vraag: Wat vond u duidelijk?

Let op!!! Probeer een zo goed mogelijk antwoord te geven.

Bedankt voor uw medewerking.

\section{Persoonlijke gegevens}

1. Wat is uw geslacht?

$\square \quad \operatorname{man}$

$\square$ vrouw

2. In welk jaar bent u geboren?

in $19 . . .$.

3. Wat is uw officiële burgerlijke staat?

$\square \quad$ ongehuwd

$\square \quad$ gehuwd

$\square$ gescheiden

$\square \quad$ weduwe/weduwnaar

4. Wat is de hoogste opleiding die u behaald heeft?

$\square \quad$ lager onderwijs

$\square \quad$ lager beroepsonderwijs / MULO / MAVO

$\square$ middelbaar beroepsonderwijs / HAVO / VWO

$\square$ hoger beroepsonderwijs / kandidaatsexamen

$\square \quad$ universitair onderwijs

$\square \quad$ anders, namelijk

5. Wat is uw functie?

6. Wat is uw functiegroep?
$\square \quad$ management
$\square \quad$ leidinggevend
$\square \quad$ niet leidinggevend
$\square$ anders, namelijk 


\section{Vragenlijst training Effectieve Communicatie}

7. Met een effectieve communicatie kan ik mijn werkprestatie verbeteren.

8. Effectieve communicatie heeft voordelen voor mijn werk.

9. Ik kan zelf een actieve bijdrage leveren aan effectieve communicatie.

10. Het heeft voor mij voordelen om mijn eigen gedrag met EC in de toekomst te veranderen.

11. Mijn leidinggevende stimuleert mij in het kader van deze training.

12. Ik heb voldoende kennis om aan de training een bijdrage te kunnen leveren.

13. Ik wordt door mijn omgeving op mijn communicatie aangesproken.

14. Ik ben tevreden over de aansturing door mijn direct leidinggevende.

15. Mijn verschillende werkzaamheden en resultaten zijn duidelijk omschreven.

16. ren.

$k$ heb voldoende randvoorwaarden om effectief te communice-

17. Ik wordt door anderen gewaardeerd als ik mij inzet voor een goede communicatie.

18. Effectieve communicatie geeft mij een positief gevoel.

19. Mijn direct leidinggevende staat positief tegenover deze training (EC).

20. Ik ontvang uit mijn directe omgeving waardering voor mijn werk.

21. Mijn collega's voelen zich verantwoordelijk voor een goede communicatie.

22. Mijn directe collega staat positief tegenover effectieve communicatie.
Geheel wel $\quad \square-\square-\square-\square-\square \quad$ Geheel niet

Heel veel $\square-\square-\square-\square-\square \quad$ Helemaal geen

Geheel eens $\quad \square-\square-\square-\square-\square \quad$ Geheel oneens

Heel veel $\quad \square-\square-\square-\square-\square \quad$ Helemaal geen

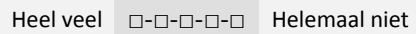

Voldoende $\square-\square-\square-\square-\square \quad$ Onvoldoende

Voldoende $\square-\square-\square-\square-\square \quad$ Onvoldoende

Geheel eens $\quad \square-\square-\square-\square-\square \quad$ Geheel oneens

Geheel eens $\square-\square-\square-\square-\square \quad$ Geheel oneens

Voldoende $\square-\square-\square-\square-\square \quad$ Onvoldoende

Geheel eens $\quad \square-\square-\square-\square-\square \quad$ Geheel oneens

Geheel eens $\quad \square-\square-\square-\square-\square$ Geheel oneens

Geheel eens $\quad \square-\square-\square-\square-\square \quad$ Geheel oneens Altijd $\quad \square-\square-\square-\square-\square \quad$ Nooit

Geheel eens $\quad \square-\square-\square-\square-\square \quad$ Geheel oneens

Geheel eens $\quad \square-\square-\square-\square-\square \quad$ Geheel oneens 
23. Ik heb een actieve (luister)houding in de interactie met anderen.

24. Mijn collega's hebben een positieve bijdrage aan mijn communicatie.

25. Ik geeft feedback aan anderen.

26. Ik ga met plezier naar mijn werk.

27. Ik heb een actieve luisterhouding.

28. Ik ben zelf verantwoordelijk voor een goede communicatie.

29. Ik sta open voor de mening van anderen.

30. Ik heb duidelijke ontwikkelafspraken (leerdoelen) over EC gemaakt.

31. Ik geef op een productieve manier kritiek op anderen.

32. Er worden goede afspraken over het werk gemaakt.

33. Mijn partner (thuis) staat positief ten opzichte van mogelijke veranderingen in het werk.

34. Ik neem eigen initiatief in het werk om de nodige dingen op te pakken.

35. Ik kan in mijn werk met ander gedrag experimenteren.

36. Ik hoor anderen waardering voor hun werkte te geven.

37. Het is goed om je eigen communicatie te willen verbeteren.

38. Ik maak met de organisatie afspraken over mijn persoonlijke ontwikkeling.

39. Mijn collega's staan open voor de mening van anderen.
Geheel eens $\quad \square-\square-\square-\square-\square \quad$ Geheel oneens

Geheel eens $\quad \square-\square-\square-\square-\square \quad$ Geheel oneens Vaak $\square-\square-\square-\square-\square \quad$ Nooit

Geheel eens $\quad \square-\square-\square-\square-\square \quad$ Geheel oneens

Geheel eens $\quad \square-\square-\square-\square-\square \quad$ Geheel oneens

Geheel eens $\quad \square-\square-\square-\square-\square \quad$ Geheel oneens

Geheel eens $\quad \square-\square-\square-\square-\square \quad$ Geheel oneens

Geheel eens $\quad \square-\square-\square-\square-\square \quad$ Geheel oneens Vaak $\square-\square-\square-\square-\square \quad$ Nooit Altijd $\quad \square-\square-\square-\square-\square \quad$ Nooit

Geheel eens $\quad \square-\square-\square-\square-\square \quad$ Geheel oneens Altijd $\quad \square-\square-\square-\square-\square \quad$ Nooit Altijd $\quad \square-\square-\square-\square-\square \quad$ Nooit Altijd $\quad \square-\square-\square-\square-\square \quad$ Nooit Geheel eens $\square-\square-\square-\square-\square \quad$ Geheel oneens Geheel eens $\square-\square-\square-\square-\square \quad$ Geheel oneens Geheel eens $\quad \square-\square-\square-\square-\square \quad$ Geheel oneens 
40. Er wordt duidelijk gecommuniceerd.

41. Mijn collega's nemen initiatief in het werk om de nodige dingen op te pakken.

42. Wat is uw mening over EC?
Geheel eens $\square-\square-\square-\square-\square \quad$ Geheel oneens

Altijd $\quad \square-\square-\square-\square-\square \quad$ Nooit

\section{Opmerkingen}

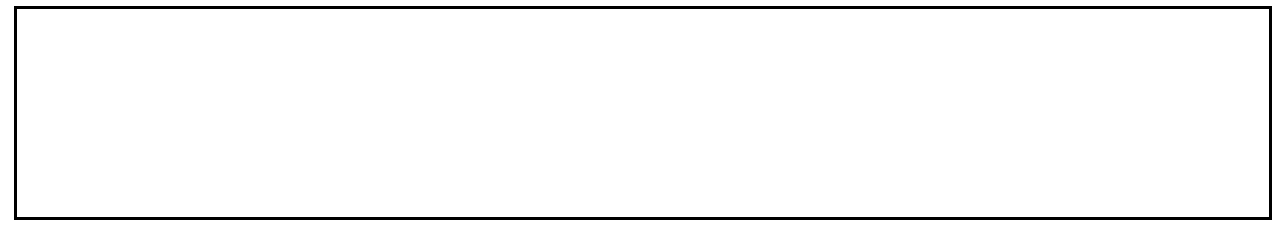




\section{Referenties}

- Abraham, C., Sheeran, P., \& Johnston, M. (1988). From health beliefs to self regulation: Theoretical advances in the psychology of action control. Psychology and Health, 13, 569591.

- Adizes, I. (1981). How to solve the mismanagement crisis. Carpinteria: Adizes Institute.

- Aguinis, H. \& Branstetter, S.A. (2007). Teaching the concept of the sampling distribution of the mean. Journal of Management Education, 31, 467-483.

- Aguinis, H. \& Kraiger, K. (2009). Benefits of training and development for individuals and teams, organizations and society. Annual Review of Psychology, 60, 451-475.

- Ajzen, I. (1985). From intentions to actions: A theory of planned behavior. In J. Kuhl en J. Beckmann (red.). Action-control: From cognition to behavior (pp. 11-39). Berlin: Springer.

- Ajzen, I. (1987). Attitudes, traits, and actions: Dispositional prediction of behavior in personality and social psychology. Advances in Experimental Social Psychology, 20, 163.

- Ajzen, I. (1991). The theory of planned behavior. Organizational Behavior and Human Decision Processes, 50, 179-211.

- Ajzen, I. (2002). Perceived behavioral control, self-efficacy, locus of control, and the theory of planned behavior. Journal of Applied Social Psychology, 32, 665-683.

- Ajzen, I., \& Fishbein, M. (1980). Understanding attitudes and predicting social behavior. Englewood Cliffs (NJ): Prentice Hall.

- Ajzen, I., \& Madden, T.J. (1986). Prediction of goal-directed behavior: Attitudes, intentions and perceived behavioral control. Journal of Experimental Social Psychology, 22, 453-474.

- Ajzen, I., Brown, T.C. \& Carvajal, F. (2004). Explaining the discrepancy between intentions and actions: The case of hypothetical bias in contingent validation. Personality and Social Psychology Bulletin, 30, 1108-1121.

- Alberga, T., Tyson, S. \& Parsons, D. (1997). An evaluation of the Investors in People Standard. Human Resource Management Journal, 7, 47-60,

- Alvarez, K., Salas, E. \& Garofano, C. M. (2004). An integrated model of training evaluation and effectiveness. Human Resource Development Review, 3, 385-416.

- Aragón-Sánchez, A., Barba-Aragón, I. \& Sanz-Valle, R. (2003). Effects of training on business results. The International Journal of Human Resource Management, 14, 956-980. 
- Armitage, C.J., \& Conner, M. (2001). Efficacy of the theory of planned behavior: A metaanalytic review. British Journal of Social Psychology, 40, 471-500.

- Arthur, W.J., Day, E.A., Bennet, W., McNelly, T.L. \& Jordan, J.A. (1997). Dynamic versus individual training protocols: Loss and reacquisition of a complex skill. Journal of Applied Psychology, 82, 783-791.

- $\quad$ Arthur, W.J., Bennet, W.J., Edens, P. \& Bell, S.T. (2003). Effectiveness of training on organizations: A meta-analysis of design and evaluation features. Journal of Applied Psychology, 88, 234-245.

- Arvey, R.D., Salas, E. \& Gialluca, K.A. (1992). Using tasks inventories to forecast skills and abilities. Human Performance, 5, 171-190.

- Assen, M. van, Berg, G. van den \& Pietersma, P. (2008). Het Groot Managementmodellenboek. Den Haag: Academic Service.

- Baarda, D.B. \& Goede, M.P.M. de (2001). Basisboek Methoden en Technieken. Houten: Noordhoff Uitgevers.

- Baldwin, T.T., \& Ford, J.K. (1988). Transfer of training: A review and directions for future research. Personnel Psychology, 41, 63-105.

- Bandura, A. (1977). Social learning theory. Engelwood-Cliffs: Prentice Hall.

- Bandura, A. (1986). Social foundations of thought and action: a social cognitive theory. New York: Prentice Hall

- Barber, J. (2004). Skill upgrading within informal training: lessons from the Indian auto mechanic. International Journal of Training and Development, 8, 128-139.

- Bartholomew, L.K., Parcel, G.S., Kok, G. \& Gottlieb, N.H. (2001). Intervention mapping; designing theory- and evidence-based health promotion programs. Mountain View, CA: Mayfield.

- Bartholomew, L.K., Parcel, G.S., Kok, G. \& Gottlieb, N.H.(2006). Planning health promotion programs: An Intervention Mapping approach (2nd ed.). San Francisco, CA: Jossey-Bass.

- Bartholomew, L.K., Parcel, G.S., Kok, G., Gottlieb, N.H., \& Fernández, M.E. (2011). Planning health promotion programs: An Intervention Mapping approach (3rd ed.). San Francisco, CA: Jossey-Bass.

- Bartholomew, L.K., Parcel, G.S. \& Kok, G., 1998. Intervention Mapping: a process for designing theory- and evidence-based health education programs. Health Education \& Behavior, 25, 545-563.

- Bender, R., Timmermans, N. \& Wesseling, A. (2001). Je kunt me nog meer vertellen. Zaltbommel: Thema 
- Bernstein, E.S. (2012). The Transparency Paradox: A Role for Privacy in Organizational Learning and Operational Control. Administrative Science Quarterly, 57, 181-216.

- Biran, A., Schmidt, W.P., Varadharajan, K.S., Rajaraman, D., Kumar, R., Greenland, K., Gopalan, B., Aunger, R. \& Curtis, V. (2014): Effect of a behaviour-change intervention on handwashing with soap in India (SuperAmma): a cluster-randomised trial. The Lancet Global Health, 2, 145-154.

- Bijl, D. (2007). Het nieuwe werken: Op weg naar een productieve kenniseconomie. Den Haag: Academic Service.

- Black, S. (2007). Apprenticeships: a tradition that works. American Schoolboard Journal, $194,38-40$.

- Blanchard, P.N., Thacker, J.W. \& Way, S.A. (2000). Training Evaluation: Perspectives and Evidence from Canada. International Journal of Training and Development, 4, 295-304.

- Blanchard, P.N. \& Thacker, J.W. (2007). Effective training: Systems, Strategies and Practices. Upper Saddle River - New Jersey: Pearson Prentice Hall.

- Boldero, J. (1995). The prediction of household recycling of newspapers: The role of attitudes, intentions, and situational factors. Journal of Applied Social Psychology, 25, 440-462.

- Boeckhardt, J.J., Nash, M.R., Murphy, M.D., Moore, M., Shaw, D. \& O’Neil, P. (2008). Clinical Practice as Natural Laboratory for Psychotherapy Research. American Psychologist, 63 (2), 77-95.

- Breejen, J. van (2004). Rendement van leren en veranderen. Zaltbommel: Thema.

- Bridges, W. (2005). Managen van transities. Zaltbommel: Thema.

- Broad, M.L. \& Newstrom, J.W. (1992). Transfer of training: Action-packed strategies to ensure high payoff from training investments. Reading, MA: Addison-Wesley.

- Brug, J., Oenema, A. \& Campbell, M. (2003). Past, present, and future of computer-tailored nutrition education. American Journal of Nutrition, 77, 1028s-1034s.

- Brug, J., Assema van, P. \& Lechner, L. (2010). Gezondheidsvoorlichting en gedragsverandering: Een planmatige aanpak. Assen: Van Gorcum.

- Caluwé, L. de \& Vermaak, H. (2004). Leren veranderen. Deventer: Kluwer.

- Campbell, D.J. \& Lee, C. (1988). Self-Appraisal in Performance Evaluation: Development versus Evaluation. The Academy of Management Review, 13, 302-314.

- Cannon-Bowers, J.A. \& Salas, E. (1998). Making Decisions under stress. Implications for individual and team training. Washington DC: American Psychological Association. 
- CBS (2011): Rapport "Bedrijfsopleidingen 2010". http://www.cbs.nl/NR/rdonlyres/E6551CA1-9A954243-AAE4-3586FB5A2496/0/2012k3v4p52art.pdf

- Chakhssi, F., Ruiter de, C. \& Bernstein, D. (2010). Change during forensic treatment in psychopathic versus nopsychopathic offenders. The Journal of Forensic Psychiatry \& Psychology, 21 (5), 660-682.

- Cherrington, D.J. (1994). Organizational behavior. Nedham Heights, MA: Allyn and Bacon.

- Coetsee W.J. \& Eiselen, R. (2006). Measuring learning transfer in a financial institution (part 2). South-African Journal of Industrial Psychology, 32, 56-63.

- Cook, T.D. \& Campbell, D.T. (1979). Quasi-experimentation: Design and analysis issues for field settings. Boston: Houghton-Mifflin.

- Coopman, B., Coopman, M., Lee, de L., Volder, de I. \& Gijbels, D. (2009). Effectiviteit van opleidingen. Een model ter oriëntatie in de veelheid van modellen en instrumenten. Opleiding \& Ontwikkeling, 1, 22-24.

- Cozijnsen, A. \& Vrakking, W.J. (2003). Handboek Verandermanagement. Deventer: Kluwer.

- Cuyvers, G. (2003). Integrale Organisatieverandering. Soest: Uitgeverij H. Nelissen.

- Dean, P.J., Dean, M.R., \& Rebalsky, R.M. (1996). Employee perceptions of workplace factors that will most improve their performance', Performance Improvement Quarterly, 9, 75-89.

- Deci, E.L. (1975). Intrinsic motivation. New York: Plenum Press.

- Dewulf, L. (2003). Gras groeit niet door er aan te trekken. Opleiding en Ontwikkeling, 16, 38.

- Dijk, C. van (1998). Assertief op het werk. Zaltbommel: Thema.

- Driskell, J.E., Willis, R.P. \& Copper, C. (1992). Effect of overlearning on retention. Journal of Applied Psychology, 77, 615-622.

- Driscoll, S. (2001). Ancient Greece: Life as a skilled craftsman in ancient Greece. New York: Great Neck Publishing.

- Empelen, P. van, Schaalma, H.P., Kok, G. \& Jansen, M. (2001). Predicting condom use with casual and steady sex partners among drugs users. Health Education Research, 16, 293305)

- Empelen, P. van, Kok, G., Schaalma, H.P. \& Batholomew, L.K. (2003). An AIDS risk reduction program for Dutch drug users: An intervention mapping approach to planning. Health Promotion Practice, 4, 402-412. 
- Epstein, S.R. (1998). Craft Guilds, Apprenticeship, and Technological Change in Preindustrial Europe. The Journal of Economic History, 58, 684-713.

- Eseryel, D. (2002). Approaches to evaluation of training: Theory and practice. Journal of Educational Technology and Society, 5, 93-98.

- Eshetu, G. (2013). Involving Children For Washing Behavior Change: Repeated Delivery to Foster Action. Hamburg: Anchor Academic Publishing.

- Fishbein, M., \& Ajzen, I. (1975). Belief, attitude, intention and behavior: An introduction to theory and research. Reading, MA: Addison-Wesley.

- Fishbein, M. \& Ajzen, I. (2010). Predicting and Changing Behavior. The Reasoned Action Approach. New York - Hove: Psychology Press.

- Fishbein, M., Hennessy, M., \& Douglas, J. (2003). Can we explain why some people do and some people do not act on their intentions? Psychology, Health and Medicine, 8, 3-18.

- Fisher-Chan, J. (2010). Training Fundamentals: Pfeiffer Essential Guides to Training Basics. San Francisco: Wiley.

- Ford, J.K. \& Weissbein, D.A. (1997). Transfer of training: An updated review and analysis. Performance Improvement Quarterly, 10, 22-41.

- Frayne, C.A. \& Geringer, J.M. (2000). Self-management training for improving job performance: A field experiment involving salespeople. Journal of Applied Psychology, 85, 361372.

- Fulmer, I.S. \& Ployhart, R.E. (2014). "Our Most Important Asset": A Multidisciplinary/Multilevel Review of Human Capital Valuation for Research and Practice. Journal of Management, 40, 161-192.

- Garson, G. D. (2008). Research Designs. http://www2.chass.ncsu.edu/garson/pA765/design.htm.

- Gerrichhauzen, J., Kamperman, A. \& Kluytmans, F. (red.) (1996). Interventies bij organisatieverandering. Deventer: Kluwer Bedrijfswetenschappen.

- Gielen, H. \& Indesteege, L. (2004). Rendement van Leeractiviteiten. Leuven-Voorburg: Uitgeverij Acco.

- Gist, M.E. \& Mitchell, T.R. (1992). Self-Efficacy: A Theoretical Analysis of its Determinants and Malleability. Academy of Management Review, 17, 183-211.

- Glynn, L.G., Hayes, P.S., Casey, M., Glynn, F., Alvarez-Iglesias, A., Newell, J., O'Laighin, G., Heaney, D., O'Donnell, M. \& Murphy, A.W. (2014): Effectiveness of a smartphone application to promote physical activity in primary care: the SMART MOVE randomized controlled trial. British Journal of General Practice, 64, 384-391.

- Godin, G. \& Kok, G. (1996). The theory of planned behavior: A review of its applications to health-related behaviors. American Journal of Health Promotion, 11, 87-98. 
- Goldstein, I.L. \& Ford, J.K. (2002). Training in organizations. Belmoth, CA: Wadsworth.

- Guthrie, J., Mancino, L. \& Jordan-Lin, C.T. (2015): Nudging Consumers toward Better Food Choices: Policy Approaches to Changing Food Consumption Behaviors. Psychology \& Marketing, 32, 501-511.

- Haccoun, R.R. \& Hamtieux, T. (1994). Optimizing knowledge tests for inferring learning acquisition levels in single group training evaluation designs: The Internal Referencing Strategy. Personnel Psychology, 47, 593-604.

- Haccoun, R.R. \& Saks, A.M. (1998). Training in the 21st century: Some lessons from the last one. Canadian Psychology, 39, 33-51.

- Hardeman, W., Johnston, M., Johnston, D.W., Bonetti, D., Wareham, N.J. \& Kinmouth, A.L. (2002). Application of the Theory of planned behavior in behavior change interventions: $A$ systematic review. Psychology and Health, 17, 123-158.

- Hasaki, E. (2012). Craft Apprentship in Ancient Greece. In: Byrkit, J.W. \& Wendrich, W. (2012). Archaeology and Apprentship, The University of Arizona Press.

- Helmreich, R.L. \& Merritt, A.C. (2001). Culture at work in aviation and medicine: National, organizational, and professional influences. London: Ashgate.

- Helmreich, R.L. \& Foushee, H.C. (1993). Why crew resource management? Empirical and theoretical bases of human factors training in aviation. In: Wiener, E.L., Kanki, B.G. \& Helmreich, R.L. (1993). Cockpit resource management (pp. 3-45), San Diego: Academic Press.

- Helmreich, R.L., Merritt A.C. \& Wilhelm J.A. (1999). The Evolution of Crew Resource Management Training in Commercial Aviation. The International Journal of Aviation Psychology, 9, 19-32.

- Holton, E.F., Chen, H.C. \& Naquin, S.S. (2003). An examination of learning transfer system characteristics across organizational settings. Human Resource Development Quarterly, 14, 459-482.

- Holton, E. F. (2005). Holton's evaluation model: New evidence and construct elaborations. Advances in Developing Human Resources, 7, 37-54.

- Hou, S., Fernadez, M. \& Parcel, G.S. (2004). Development of a cervical cancer education program for Chinese woman using intervention mapping. Health Promotion Practice, 8, 8087.

- Jaccard, J. (2012): The Reasoned Action Model: Directions for future research. The Annals of the American Academy, 640, 58-80.

- Jansman, R. \& Vries, de K. (2011). Succesvol veranderen. Nijmegen - Bindje.

- Jorgensen, B.S. \& Martin, J.F. (2014). Understanding farmer intentions to connect to a modernised delivery system in an Australian irrigation district: a reasoned action approach. Journal of Environmental Planning and Management, jan. 2014, 1-24. 
- Kaiser, F.G. \& Gutscher, H. (2003). The proposition of a general version of the theory of planned behavior: Predicting ecological behavior. Journal of Applied Social Psychology, 33, 586-603.

- Kamer van Koophandel (2014). Rapport startersprofiel 2013. Startende ondernemers in beeld. Kamer van Koophandel Nederland.

- Khattri, N. (2015): Impact of Television on HIV/AIDS Awareness in Delhi Slums. The international Journal of Communication and Health, 5, 28-35.

- Kirkpatrick, D.L. \& Kirkpatrick, J.D. (2006). Evaluating training programs: The four levels, 3rd ed. San Franciso: Berrett-Koehler Publishers.

- Kirkpatrick, D.L. (1975). 'Techniques for Evaluating Training Programs'. Evaluating training programs, Alexandria, VA: ASTD.

- Kleijn, H. \& Rorink, F. (2005). Verandermanagement. Amsterdam: Pearson Education.

- Kluytmans, F. \& Bouwen, R. (1998). Over veranderen, ontwikkelen en transformeren. In J. Gerrichhauzen, A. Kamperman \& F. Kluytmans (red.), Interventies bij organisatieverandering (pp. 43-65). Deventer: Kluwer Bedrijfswetenschappen.

- Knowlden, A.P., Sharma, M. \& Bernard, A.L. (2012). A theory of planned behavior research model for predicting the sleep intentions and behaviors of undergraduate college students. Journal of Primary Prevention, 33, 19-31.

- Koekkoek, B., Meijel, van B., Schene, A. \& Hutschemaekers, G. (2010). Development of an intervention program to increase effective behaviors by patients and clinicians in psychiatric services: Intervention Mapping study. Health Service Research, 10, 1-11.

- Kontoghiorghes, C. (2004). Reconceptualizing the learning transfer conceptual framework: empirical validation of a new systemic model. International Journal of Training and Development, 8, 210-221.

- Koslowsky, M., Hoffman, N., \& Lazar, A. (1990). Predicting behavior on a computer from intentions, attitudes, and experience. Current Psychology: Research and Reviews, 9, 75-83.

- Kotter, J.P. (1996). Leading Change. Harvard Business School Press.

- Kreijns, K., Vermeulen, M., Acker van, F. \& Buren van, H.(2014.: Predicting teachers' use of digital learning materials: combining self-determination theory and the integrative model of behavior prediction. European Journal of Teacher Education, online publication, Jan. 2014.

- Kreijns, K., Vermeulen, M., Kirschner, P.A.; Buuren van, H. \& Acker van, F. (2013). Adopting the Integrative Model of Behavior Prediction to explain teachers' willingness to use ICT: $A$ perspective for research on teachers' ICT usage in pedagogical practices. Technology, $\mathrm{Pe}$ dagogy and Education, 22, 55-71. 
- Laane, R., \& Luijk, R. (2012). ROM en positie van de zorgverzekeraars. Tijdschrift voor Psychiatrie, 54, 135-139.

- Lakerveld, J. van, Oudendammer, F. den, \& Stam, D. (2003). Als het tij verloopt, moet men de bakens verzetten: inventarisatie van trends in de branche van bedrijfsopleiders. Leiden: Plato Kennisbalans.

- Landsberger, H.A. (1958): Hawthorne Revisited . Ithaca, NY: Cornell University.

- Leerlooijer, J.N., Ruiter, R.A.C., Reinders, J., Darwisyah, W., Kok, G. \& Bartholomew, L.K. (2013). The World Starts With Me: using intervention mapping for the systematic adaptation and transfer of school-based sexuality education from Uganda to Indonesia. Translational Behavior Medicine, 1, 331-340.

- Levin, P.F. (1999). Test of the Fishbein and Ajzen models as predictor of health care worker's glove use. Research in Nursing and Health, 22, 295-307.

- Linou, N. \& Kontogiannis, T. (2004): The effect of training systemic information on the retention of fault-finding skills in manufacturing industries. Human Factors and Ergonomics in Manufacturing \& Service Industries, 14(2), 197-217.

- Locke, E.A., \& Latham, G.P. (1990). A theory of goal setting and task performance. New Jersey: Englewood Cliffs.

- Mabey, C. \& Ramirez, M. (2005). Does management development improve organizational performance? A six-country analysis of European firms. International Journal of Human Resource Management, 16, 1067-1082.

- Mathieu, J.E., Martineu, J.W. \& Tannenbaum, S.I. (1993). Individual and situational influences on the development of self-efficacy: Implications for training effectiveness. Personnel Psychology, 46, 125-147.

- Mayo, E. (1945). Social Problems of an Industrial Civilization. Boston: Division of Research, Graduate School of Business Administration, Harvard University.

- McEachan, R.R.C., Conner, M., Taylor, N.J. \& Lawton, R.J. (2011). Prospective prediction of health-related behaviors with the Theory of Planned Behavior: a meta-analysis. Health Psychology Review, 5, 97-144.

- Michie, S. \& Abraham, C. (2004). Interventions to change health behavior: Evidence-based or evidence-inspired? Psychology and Health, 19, 29-49.

- Nagelhout, G.E., Wiebing, M.A., Putte van den, B., Vries de, H., Crone, M., Bot, S.M. \& Willemsen, M.C. (2014). 'Ik wed dat ik het kan!' - Bereik en effect van een televisieprogramma over stoppen met roken bij laag-, middelbaar en hoogopgeleide rokers. Tijdschrift voor gezondheidswetenschappen,92, 84-92. 
- Newton, J.T. \& Asimakopoulou, K. (2015): Managing oral hygiene as a risk factor for periodontal disease: a systematic review of psychological approaches to behaviour change for improved plaque control in periodontal management. Journal of Clinical Periodontology, $42,36-46$.

- Obdein, S. \& Lubberts, M. (2013). Haal je kop uit het zand. Den Haag: Performa Uitgeverij.

- Ouden, M. den (1992). Transfer na bedrijfsopleidingen. Amsterdam: Thesis Publishers.

- Peters, T.J. \& Waterman, R.H. (1982). In search of excellence: Lessons from America's bestrun companies. Harper Collins Publishers, London.

- Pham, N.T.P., Segers, M.S.R. \& Gijselaers, W.H. (2013). Effects of work environment on transfer of training: empirical evidence from Master of Business Administration programs in Vietnam. International Journal of Training and Development, 17, 1-19.

- Phillips, J. \& Phillips, P. (2007). Show Me the Money: How to Determine ROI in People, Projects and Programs. San Francisco: Berrett-Koehler Publishers, Inc.

- Poiesz, T.B.C. (1999). Gedragsmanagement: Waarom mensen zich (niet) gedragen. Wormer: Inmerec BV.

- Quinn, R.E. \& Cameron, K. (1999). Onderzoeken en veranderen van organisatiecultuur. Schoonhoven: Academic Service.

- Quinn, R.E. (2003). Persoonlijk meesterschap in management - Voorbij rationeel management. Schoonhoven: Academic Service.

- Quinn, R.E., Faerman, S.R., Thompson, M.P. \& McGrath, M.R. (1994). Handboek management vaardigheden. Schoonhoven: Academic Service.

- Rauner, M., Groot, de S., Kok, G. \& Taris, T. (2009): Betrouwbare Effectmeting zonder Controlegroep. Opleiding \& Ontwikkeling, 22, 15-18.

- Rauner, M., Kok, G., \& Taris, T. (2005). De effectiviteit van een communicatietraining: Een vergelijking van de effectiviteit van een maatwerkprogramma en een standaardprogramma binnen een training effectieve communicatie. Gedrag \& Organisatie, 19, 3-21.

- Ree, M.J., Carretta T.R. \& Teachout, M.S. (1995). Role of ability and prior job knowledge in complex training performance. Journal of Applied Psychology, 80, 721-730.

- Robson, C. (2002). Real World Research. Oxford: Blackwell Publishers.

- Russ-Eft, D., \& Preskill, H. (2005). In search of the Holy Grail: Return on investment evaluation in human resource development. Advances in Developing Human Resources, 7, 71-85.

- Salas, E. \& Cannon-Bowers, A. (2001). The science of training: a decade of progress. Annual Review of Psychology, 52, 471-499. 
- Salas, E. \& Kosarzychi, M.P. (2003). Why don't organizations pay attention to (and use) findings from the science of training? Human Resource Development Quarterly, 1, 487-491.

- Schaalma, H. (1993). De analyse van gedragsdeterminanten. In: Damoiseaux, V., Molen van der, H.T. \& Kok, G. (red.), Gezondheidsvoorlichting en gedragsverandering, (pp. 133-167). Assen - Van Gorcum.

- Schaalma, H., Kok, G., \& Meertens, R.M. (2001). Intervention mapping. In J. Brug, H. Schaalma, G. Kok, R.M. Meertens \& H.T. van der Molen (red.), Gezondheidsvoorlichting en gedragsverandering: Een planmatige aanpak (pp. 133-167). Assen: Van Gorcum.

- Schaalma, H. \& Kok, G., (2007). Interventieontwikkeling. In: J. Brug, P. van Assema \& L. Lechner (Red.), Gezondheidsvoorlichting en gedragsverandering; een planmatige aanpak (pp. 107-122). Assen, NL: Van Gorcum.

- Schaffer, R.H. \& Thomson, H.A. (2000). Succesvolle veranderingstrajecten beginnen met resultaten. In: Harvard Business Review: Over verandering. Zaltbommel: Thema.

- Scherpbier, A.J.J.A., Verwijnen, G. N., Schaper, N., Dunselman, G.A.J. \& Vleuten van der, C.P.M. (2000). Vaardigheidsonderwijs nu en in de toekomst. Tijdschrift voor Medisch Onderwijs, 19 (1), 6-15.

- Schifter, D.B. \& Aijzen, I. (1985). Intention, perceived control and weight loss: an application of the theory of planned behavior. Journal of Personality and Social Psychology, 49, 843-851.

- Schultz, D.P. \& Schultz, S.E. (2006). Psychology and work today. New York: Prentice Hall.

- Sniehotta, F., Presseau, J. \& Araújo-Soares, V. (2014). Time to retire the theory of planed behavior. Health Psychology Review, 8, 1-7.

- Spitzer, D.R. (2005): Learning Effectiveness Measurement: A New Approach for Measuring and Managing Learning to Achieve Business Results. Advances in Developing Human Resources, 7, 55-70.

- Steen, van der W.J. (2003): De blindheid van dubbelblind onderzoek. Tijdschrift voor Integrale Geneeskunde, 19 (6), 357-360.

- Sulak, T.N., Saxon, T.F. \& Fearon, D. (2014). Applying the Theory of Reasoned Action to Domestic Violence Reporting Behavior: The Role of Sex and Victimization. Journal of Family Violence, 29, 165-173.

- Tannenbaum, S.I. \& Yukl, G. (1992). Training and Development in Work Organizations. Annual Review of Psychology, 43, 399-441.

- Tannenbaum, S.I., Methieu, J.E., Cannon-Bowers, J.A. \& Salas, E. (1993). Factors that Influence Training Effectiveness: A Conceptual Model and Longitudinal Analysis. Technical Report at the Naval Training System Center, State University New York. 
- Taylor, F.W. (1911): The Principles of Scientific Management. New York: Harper Bros.

- Taylor, P.J., Russ-Eft D.F. \& Chan, D.W.L. (2005): A meta-analytic review of behavior modeling training. Journal of Applied Psychology, 56, 363-381.

- Terranova, C.O., Brakenridge, C.L., Lawler, S.P., Eakin, E.G. \& Reeves, M.M. (2015): Effectiveness of lifestyle-based weight loss interventions for adults with type 2 diabetes: a systematic review and meta-analysis. Diabetes, Obesity and Metabolism, 17, 371-378.

- Thierry, Hk. (1992). Motivatie en satisfactie. In P.J.D. Drenth, Hk. Thierry, en Ch.J. de Wolff (red.), Nieuw handboek arbeids- en organisatiepsychologie (pp. 3-69). Houten: Bohn Stafleu van Loghum.

- Tracey, J.B., Hinkin, T.R., Tannenbaum S.I. \& Mathieu, J.E. (2001). The influence of individual characteristics and the work environment on varying levels of training outcomes. Human Resources Development Quarterly, 12, 5-23.

- Veen, P. (1992). Organisatietheorieën. In P.J.D. Drenth, Hk. Thierry, \& Ch.J. de Wolff (red.), Nieuw handboek arbeids- en organisatiepsychologie (pp. 541-583). Houten: Bohn Stafleu van Loghum.

- Ven, van de M.O.M., Engels, R.C.M.E., Otten, R. \& Eijnden van den, R.J.J.M. (2007). A longitudinal test of the theory of planned behavior predicting smoking onset among asthmatic an non-asthmatic adolescents. Journal of Behavioral Medicine, 30, 435-445.

- Velada, R., Caetano, A., Michel, J.W., Lyons, B.D. \& Kavanagh, M.J. (2007). The effects of training design, individual characteristics and work environment on transfer of training. International Journal of Training and Development, 11, 282-294.

- Vries, H. de, Weijts, W., Dijkstra, M., \& Kok, G. (1992). The utilization of qualitative and quantitative data for health education program planning, implementation, and evaluation: A spiral approach. Health Education Quarterly, 19, 101-115.

- Vries, R. (2003): Procesgericht biologieonderwijs: Samen actief op weg naar constructief studeren. Proefschrift aan de Technische Universiteit Eindhoven.

- Wang, G.G. \& Wilcox, D. (2006). Training evaluation: Knowing more than is practiced. Advances in Developing Human Resources, 8, 528-539.

- Waterman, R.H. (1982). The seven elements strategic fit. Journal of Business Strategy, 2, 69-73.

- Waterman, R.H., Peters, T.J. \& Phillips, J.R. (1980): Structure Is Not Organisation. Business Horizons, 23, 14-26.

- Wells, K.B. (1999). Treatment Research at the Crossroads: The Scientific Interface of Clinical Trials and Effectiveness Research. American Journal of Psychology, 156, 5-10. 
- Wilson, M.A. \& Zalewski, M.A. (1994): An expert system for abilities-oriented job analysis. Computers in Human Behavior, 10, 199-207.

- XTNT (2013). Onbewuste invloeden op gedrag. In opdracht van het Ministerie van Infrastructuur en Milieu. 


\section{Valorisatie-Addendum}

Opleiden en begeleiden van gedragsverandering is en blijft populair in Nederland. De commerciële dienstverlening waaronder coaching-, training- en adviesbureaus vallen, blijft een groeiende sector en heeft een substantieel aandeel onder de startende ondernemingen, inclusief ZZP'ers (Kamer van Koophandel, 2014). Nederland kent nog steeds een positief klimaat voor dergelijke ondernemingen en ieder jaar wordt door individuele personen en organisaties miljarden euro's geïnvesteerd in, opleidingen, (gedrags)trainingen, organisatieontwikkeling of enige andere vorm van (gedrags)verandering. Ook zijn organisaties continu in verandering en worden door de veranderende samenleving, de ontwikkeling van de informatietechnologie, kenniseconomie, multiculturaliteit, diversiteit in het algemeen, de toenemende concurrentie en de globalisering, gedwongen zich voortdurend aan te passen aan de omgeving. Dit heeft wederom tot gevolg dat organisaties zich permanent vernieuwen. Op basis van strategisch beleid veranderen daarmee doelen, structuren, processen en culturen. Uiteraard zijn deze veranderingen ook van invloed op de werknemers. De kenniswerker doet zijn intrede, beter geformuleerd de 'flexibele medewerker', is een groot goed in organisaties en het 'nieuwe werken' is aan een revival begonnen. Daarmee worden ook steeds hogere eisen gesteld aan het persoonlijke functioneren van de werknemer en aan diens aanpassingsvermogen. Medewerkers krijgen meer verantwoordelijkheid, moeten in veranderende situaties flexibel hun taken kunnen uitvoeren en er wordt van hen verwacht dat zij dezelfde werkzaamheden in een korter tijdsbestek verrichten.

Geen wonder dat een leger aan adviseurs, coaches, trainers en begeleiders deze verandering in goede banen wil leiden en het (soms wanhopige) management gretig gebruik maakt van externe hulp. De doelen van deze verandering kunnen verschillend van aard zijn, terwijl het middel, training en advies, vaak hetzelfde blijft. Een probleem dat hiermee gepaard gaat, is dat de uitkomst van dergelijke interventies vaak moeilijk te meten of te voorspellen is. Het meest recente grootschalige onderzoek door het CBS in 2011 laat onder andere zien dat:

- rond $2 \%$ van de loonsom (dat is ruim $€ 6$ miljard) wordt geïnvesteerd in de individuele ontwikkeling van medewerkers (CBS, 2011);

- per jaar circa $36 \%$ van de werknemers in een organisatie een vakopleiding volgen; en

- er per jaar ongeveer $€ 1,6$ miljard wordt geïnvesteerd in vakopleidingen, waarbij de talrijke persoonlijke en niet aan het vak gerelateerde opleidingen of kosten voor externe adviseurs niet eens zijn meegenomen (CBS, 2011).

Gezien deze economische waarde zou men kunnen denken, dat de belangstelling juist meer komt te liggen op het verkrijgen van inzichten in het rendement en de effecten van een gekozen interventiestrategie. Het blijft immers een investering die rendement moet opbrengen. Echyer, weinig organisaties hebben aandacht voor wetenschappelijk onderzoek naar de effecten van een (gedrags)interventie en ook aan de aanbodkant worden weinig activiteiten ondernomen om de effectiviteit van hun eigen product aan te tonen. Daardoor is het voor de deelnemer en opdrachtgever een lastige zaak de kwaliteit van een aanbieder goed te beoordelen en blijft een evaluatie vaak beperkt tot een evaluatieformulier achteraf en de obligate vraag van de (lijn)chef of het nog gezellig is geweest. Ook voor de overheid zou het aantrekkelijk zijn om gerichter het rendement van opleidingen te kunnen beoordelen. 
In de wereld der gedragsverandering bestaan talloze theorieën over de manier waarop gedragsverandering in organisaties zou moeten worden georganiseerd. In de praktijk blijft het echter moeilijk om een beredeneerde keuze voor een van deze benaderingen te maken. Dit promotieonderzoek richt zich dan ook niet op het vinden van de beste interventiestrategie, maar biedt een methode om het effect van een (gedrags)interventie te meten en het proces daarvan te optimaliseren. Daarmee biedt het ook een 'standaardmethode' om de diverse interventies met elkaar te kunnen vergelijken. De ontwikkelde methode richt zich vooral op trainings- en adviesbureaus als aanbieders en organisaties, medewerkers en overheden als afnemers van (gedrags)interventies. Naast een ontwikkelde standaardmethode voor het implementeren en evalueren van (gedrags)interventies is een korte vragenlijst ('quick scan') ontwikkeld, die helpt bij het opsporen van belemmerende en bevorderende factoren en het opstellen van een interventiestrategie en die de effectiviteit van de interventie meet. Om dit te realiseren, zijn beproefde concepten uit de gezondheidspsychologie (denk aan veilig vrijen, gezond eten, e.d.) toegepast bij (gedrags)interventies in organisaties. Uitgangspunt was zich vooral te richten op de vraag welke voorwaarden aanwezig moeten zijn om verwachtingen om te zetten in concreet gedrag. Dit is de basis voor succesvolle interventies en organisatieveranderingen. Een meer op het proces gerichte aanpak had dan ook de voorkeur. De omgeving wordt daarin niet gezien als manipulator van behoeften, maar als een schepper van voorwaarden die maken dat een hoogst individuele behoefte kan worden omgezet in daadwerkelijke prestaties.

In dit onderzoek is specifiek een link gelegd tussen doelstelling, interventie en het effect van (gedrags)verandering. Als theoretisch kader is gebruik gemaakt van de 'Reasoned Action Approach' (Fishbein \& Ajzen, 2010). Om het inzicht in deze benadering en het effect van de op deze benadering gebaseerde interventie te vergroten, is het onderzoek uitgevoerd aan de hand van de in 'Intervention Mapping' (IM) beschreven stappen (Bartholomew et al., 2006; Schaalma et al., 2001). IM staat niet voor één bepaalde aanpak van gedragsverandering. Wel biedt IM de manager of organisatieadviseur een tool waarmee deze een bewuste keuze kan maken uit al bestaande interventiestrategieën, én het effect daarvan kan monitoren. De uitkomst is een wetenschappelijk onderbouwde methode en vragenlijst die door organisaties of adviseurs kan worden toegepast om het effect van interventies te meten, het rendement te verhogen en onnodige kosten te voorkomen. 


\section{Samenvatting}

Blijvende gedragsverandering als gevolg van een (gedrags)interventie of training blijkt in de praktijk een lastige zaak. Desondanks worden door organisaties per jaar miljarden euro's geïnvesteerd in (om- en bij-)scholingstrajecten (CBS, 2011). Voor organisaties zou het derhalve van belang kunnen zijn om voor een interventie een inschatting te kunnen maken van de kosten en de mogelijke opbrengsten daarvan. Ook lijkt het aantrekkelijk om het gedrag van medewerkers door middel van gerichte interventies zo efficiënt mogelijk in een gewenste richting te kunnen sturen en zou men verwachten dat organisaties het belang van onderzoek naar de effectiviteit en de procesverbetering van trainingen zouden waarderen. Desondanks concluderen Salas en Kosarzycki (2003) dat organisaties (de afnemers van trainingen) weinig gebruik maken van wetenschappelijke resultaten, omdat zij zelf vaak een eenvoudige opvatting over gedragsverandering hebben en extra kosten voor onderzoek willen vermijden. Anderzijds lukt het, volgens Salas en Kosarzycki (2003), veel wetenschappers niet om onderzoeksresultaten te vertalen in praktische en toepasbare concepten die redelijk eenvoudig in de praktijk kunnen worden toegepast. Organisaties zijn vaak beducht voor ingewikkelde theorieën en tegelijkertijd zijn veel onderzoeksresultaten moeilijk toegankelijk voor niet-wetenschappers. Aanleiding genoeg om het proces van gedragsinterventies te optimaliseren.

In dit proefschrift wordt verondersteld dat een gedragsverandering langer zal beklijven indien er gebruik wordt gemaakt van een theoriegestuurd interventieprogramma (gebaseerd op de 'Reasoned Action Approach' van Fishbein en Ajzen, 2010) en er geïmplementeerd wordt volgens de principes van 'Intervention Mapping' (Bartholomew et al., 2011). In hoofdstuk 1 is dit vraagstuk verder uitgewerkt en worden de onderzoeksvraagstellingen geformuleerd. Een centrale aanname is dat door het opsporen van bevorderende en belemmerende factoren ten opzichte van gewenst gedrag en het duidelijk afbakenen van de gewenste doelstelling meer rendement wordt behaald dan wanneer dat niet gebeurt. De nadruk ligt daarbij op het meten en vergoten van de effectiviteit van (gedrags)interventies/trainingen in de praktijk. Ook wordt onderzocht hoe interventies goed met elkaar kunnen worden vergeleken. Voor het onderzoek zijn de volgende deelvragen geformuleerd:

1. Hoe kan de effectiviteit van gedragstrainingen worden gemeten?

2. Welke factoren zijn van invloed op de effectiviteit van gedragstrainingen?

3. Hoe kunnen gedragstrainingen worden geoptimaliseerd?

4. Wat is de invloed van terugkoppeling aan de deelnemers over het beoogde resultaat belemmerende en bevorderende factoren?

5. Hoe kunnen interventies op het gebied van gedragsverandering goed met elkaar worden vergeleken?

In hoofdstuk 2 wordt het theoretisch kader van dit proefschrift uiteengezet. Na een korte historische beschouwing staan hierin de twee reviews van Salas en Cannon-Bowers (2001) en van Aguinis en Kraiger (2009) centraal, die een goed overzicht van onderzoek naar effectiviteit van gedragsinterventies over de afgelopen twee decennia schetsen. Zij concluderen dat er een breed scala aan onderzoeken en resultaten beschikbaar is. Opvallend is wel dat deze door de verscheidenheid aan uitgangspunten en opzet moeilijk met elkaar zijn te vergelijken. 
Hun aanbeveling is dat toekomstig onderzoek naar het effect van trainingsinterventies zich dan ook meer zou moeten richten op:

- een integrale aanpak die meer aansluit bij de behoefte van de deelnemers;

- meer aandacht voor de transfer in de toekomst;

- situationele aspecten en dan vooral de barrières die nieuw gedrag in de weg kunnen staan;

- duidelijke doestellingen, individuele verwachting ('self-efficacy') en een relatie tussen trainingssituatie en praktijk ('outcome-expectancy');

- een flexibele aanpak in leerinterval en meetmomenten;

- de omstandigheden waarbinnen een training wordt gegeven;

- het betrekken van de omgeving bij de training;

- meer 'evidenced based' interventies;

- een duidelijke evaluatiemethode; en

- een meer procesmatig aanpak waarin de participanten van hun fouten leren.

Gebaseerd op deze aanbevelingen wordt in hoofdstuk 2 een geïntegreerde methode voor procesverbetering van (gedrags)interventies in organisaties uitgewerkt. De basis daarin vormt het 'Reasoned Action Model' uit de 'Reasoned Action Approach' van Fishbein en Ajzen (2010) in combinatie met de principes van 'Intervention Mapping' (Bartholomew et al., 2001; 2006; 2011; Schaalma et al., 2001). Het 'Reasoned Action Model' vormt daarbij de basis voor het meetinstrumentarium en geeft met de drie factoren 'attitude', 'ervaren norm' en 'ervaren controle' de mogelijkheid een interventie maximaal aan te laten sluiten bij de gewenste doelstelling. De 'Intervention Mapping' methode vormt het raamwerk voor het proces waarbinnen diverse interventies, trainingen en gedragsveranderingen kunnen plaatsvinden.

De ontwikkelde methode wordt in hoofdstuk 3 aan de hand een gecontroleerd trainingsprogramma met een interventie- $(N=35)$ en een controlegroep $(N=19)$ getoetst. De uitkomsten suggereren, dat de ontwikkelde methode (een meetinstrument gebaseerd op het 'Reasoned Action Model' en een programma volgens de principes van 'Intervention Mapping' ) een goed uitgangspunt vormt om gedrag in te kaderen en het effect van gedragsverandering te meten (deelvraag 1). 'Intervention Mapping' lijkt zoals verwacht een effectieve strategie om beoogd gedrag op langere termijn (follow-up na 3 maanden) positief te beïnvloeden. Daarbij werd voor de interventiegroep een duidelijke verbetering op alle variabelen uit het 'Reasoned Action Model' aangetroffen, in tegenstelling tot de controlegroep waar geen veranderingen werden waargenomen (deelvraag 2 en 3). Daarnaast bood 'Intervention Mapping' als procesaanpak de deelnemers inzicht in het eigen gedrag en mogelijke oplossingsrichtingen. Door gericht een aantal processtappen te doorlopen worden de betrokken personen gedwongen het veranderdoel duidelijk in te kaderen en op zoek te gaan naar bij het probleem passende oplossingsrichtingen (deelvraag 4). Hiermee worden deelvragen $1 \mathrm{t} / \mathrm{m} 4$ van dit onderzoek beantwoord.

Om het inzicht in de gekozen methode te vergroten en een antwoord op de vraag te kunnen geven hoe interventies op het gebied van gedragsverandering goed met elkaar kunnen worden vergeleken (deelvraag 5), wordt in hoofdstuk 4 in drie casestudies beschreven hoe de ontwikkelde methode, onder minder gecontroleerde omstandigheden, tot procesverbetering van gedragsinterventies kan leiden.

De resultaten laten zien, dat het 'Reasoned Action Model' een goede indicator geeft om mogelijke barrières bij participanten ten opzichte van de gewenste gedragsverandering op te sporen en te meten. Wat het meetbaar maken van de effectiviteit betreft zo heeft zich het meetinstrument als zodanig bewezen. Moeilijker bleek het concretiseren van de gedragscriteria zoals 
Fishbein en Ajzen omschrijven in hun 'Reasoned Action Approach'. De validiteit beperkt zich dan ook tot expertvaliditeit. 'Intervention Mapping' dwong de organisatie om de doelstelling (en daardoor ook het probleem) duidelijk in te kaderen, zelf interventiestrategieën te kiezen en het effect daarvan te monitoren. Bovendien is duidelijk geworden dat de factor 'ervaren norm' uit het 'Reasoned Action Model' een belangrijke invloed had op het gekozen proces. Minder duidelijk is de statistische onderbouwing van de casestudies, omdat een followupmeting ontbreekt, geen gebruik kon worden gemaakt van een controlegroep en er sprake is van kleine groepsomvang. De toepassing van 'Intervention Mapping' bleek uitermate praktisch en ondersteunend in het proces. Zo wordt een gemakkelijk te volgen stappenplan vormgegeven en kunnen de gekozen interventies goed met elkaar worden vergeleken. Tevens legt 'Intervention Mapping' een groot deel van de verantwoordelijkheid voor de gekozen oplossingsrichting duidelijk bij de probleemeigenaar en bevordert hierdoor de herkenbaarheid en betrokkenheid bij de deelnemers.

Omdat uit praktische overwegingen bij alle casestudies een controlegroep ontbreekt, wordt in hoofdstuk 5 beschreven hoe de verklarende waarde van de gekozen aanpak en van het meetinstrument kan worden verhoogd door gebruik te maken van de zogenoemde 'Internal Referencing Strategy' (Garson, 2008; Haccoun \& Hamtieux, 1994), ook wel bekend als het 'Non Equivalent Dependent Variable Design' (Cook \& Campbell, 1979). Met de 'Internal Referencing Strategy' (IRS) worden de effecten van een training of interventie vergeleken met gedragsaspecten die juist niet zouden moeten worden beïnvloed. Dit deelonderzoek $(N=32)$ is uitgevoerd bij een in-company training voor start-, functionerings- en beoordelingsgesprekken (SFB) van een overheidsorganisatie met 4.000 medewerkers. Daarbij is de doelgroep verdeeld in een experimentele groep (die de training volgt) en een controlegroep die geen training volgt. Ook bij dit onderzoek is gebruik gemaakt van de eerder ontwikkelde vragenlijst gebaseerd op 'Reasoned Action Approach' aangevuld met onderzoeksvragen van de IRS. Het betreft daarbij gedragsaspecten die weinig te maken hebben met de doelstelling van de training. Daarnaast is het onderzoeksproces volgens de principes van 'Intervention Mapping' uitgevoerd. De uitkomsten geven voldoende aanwijzing dat dat de 'Internal Referencing Strategy' een betrouwbare methode is om zonder controlegroep een effectstudie uit te kunnen voeren. Voor de toepassing van de eerder ontwikkelde vragenlijst gebaseerd op het 'Reasoned Action Model' is aangetoond dat 'Internal Referencing Strategy' in voldoende mate de effecten van een gedragsinterventie meet zonder dat het gebruik van een controlegroep noodzakelijk is.

In hoofdstuk 6 worden de uitkomsten van de uitgevoerde onderzoeken besproken door conclusies in relatie tot de vraagstelling op te stellen. Deze geven aan, dat met de in dit onderzoek ontwikkelde methode (en ontwikkeld meetinstrument) gebaseerd op de 'Reasoned Action Approach' het effect van (gedrags)interventies goed kan worden gemeten. In dat verband bewees 'Intervention Mapping' zich als een goede aanvulling, omdat samen met de doelgroep naar het probleem en de gewenste uitkomst wordt gekeken en daarmee de betrokkenheid bij de doelgroep wordt vergroot. Door de deelnemers bij de ontwikkeling van het meetinstrument te laten participeren, was het gemakkelijker de uitkomstcriteria te omschrijven. Over de factoren die van invloed zijn op de effectiviteit van gedragsverandering in het algemeen kan dit onderzoek geen eenduidig antwoord geven. Wel biedt de ontwikkelde methode een handzaam instrumentatrium om specifieke factoren aan te wijzen die van invloed zijn op de effectiviteit van een interventie en die een veranderproces bevorderen of belemmeren. Meer duidelijkheid geeft dit onderzoek met betrekking tot het optimaliseren van gedragstrainingen. Door toepassing van de in 'Intervention Mapping' beschreven processtappen, door het betrekken van de doelgroep bij de gekozen interventie en door het gericht geven van terugkoppeling aan de deelnemers over het beoogde resultaat belemmerende en bevorderende factoren, wordt 
de effectiviteit van de trainingen vergroot. Verder geeft dit onderzoek een goede indicatie dat door het systematisch toepassen van de principes van 'Intervention Mapping' in combinatie met een effectmeting gebaseerd op het 'Reasoned Action Approach' een methode is om onderzoeken naar gedragsverandering met elkaar te kunnen vergelijken. Juist omdat de nadruk wordt gelegd op een duidelijke analyse van het probleem en het meten van daadwerkelijk waarneembaar gedrag, bleek deze aanpak zeer waardevol voor de praktijk. Ten slotte wordt dit proefschrift afgerond met een korte discussie en aanbevelingen voor vervolgonderzoek. 


\section{Summary}

Long-term behaviour change as a result of a training or intervention is difficult to achieve. Nevertheless, organizations and individuals spend billions of euro's on training and development (CBS, 2011). To change behaviour of employees into expected directions and to get a grip on the costs and benefits of the workforce is still an attractive challenge - reason enough to optimize the process of training and interventions on behavior in organizations. Contrary to this Salas and Kosarzycki (2003) conclude that most organizations that invest in training interventions are not using scientific results because they often have a simple understanding of behaviour and avoid additional costs for research. In addition many researchers are unable to transform their results into applicable and practical concepts that can be fairly easily applied. Organizations are afraid of complicated theories and many results of scientific research are not available for free. Logically, it seems to be a challenge to optimize the process of (behavioural) interventions and to fit the gap between research-based results and the use of it in practise. The present study assumes that a training or intervention will have a stronger impact by using a theory-based intervention program (based on Fishbein \& Ajzen's, Reasoned ActionApproach, 2010), and implemented according to a structured method (based on the principles of 'Intervention Mapping' , Bartholomew et al., 2011).

In chapter 1 the main issues are elaborated after a short introduction on the context of this research. The key assumption is that knowledge about conductive and obstructive factors and a clear description of the achievable goals have a positive influence on the result of an (behaviour) intervention (more so than if it did not happen). The focus of this research is to measure and increase the result of (behaviour) interventions in practise. It also examined how interventions in a different context can be properly compared with each other. For the study, the following main questions are formulated:

1. How can the effectiveness of a behaviour intervention be measured?

2. Which factors are influencing the effectiveness of behaviour interventions?

3. How can behaviour interventions optimized?

4. What is the influence of feedback about conductive and obstructive factors on the result of behavior interventions?

5. How can behavior interventions be compared in practise?

A short historical background and the theoretical bases of this research is given in chapter 2 . The reviews of Salas and Cannon-Bowers (2001) and Aguinis and Kraiger (2009) give a detailed summery of research into the effectiveness of behavioural interventions over the past two decades. They conclude that there is a wide range of research and scientific results available and the quantity of theoretical explanations has increased extremely. On the other hand there is a wide variety of research approaches and results, that makes them hard to compare. They recommend that further research has to be based on:

- an integrated approach and focused on the needs of the target group;

- transfer in the future:

- the situational aspects of barriers towards new behaviour:

- result-orientated goals, the self-efficacy of an individual, and the relation between training and practise (outcome-expectancy):

- a flexible approach in time and measurement:

- the circumstances of the training conditions:

- involvement of the peer group;

- evidenced-based interventions. 
- A clear evaluation method; and

- A process orientated approach, to learn from the achieved results.

In accordance with these recommendations an integrated method is developed in chapter 2 to improve the process of changing behaviour in organisations. The basic principles of that method are the 'Reasoned Action Model' based on the 'Reasoned Action Approach' (Fishbein \& Ajzen, 2010) combined with the principles of the 'Intervention Mapping' approach (Bartholomew et al., 2001; 2006; Schaalma et al., 2001). The 'Reasoned Action Model' with its three factors ('Attitude', 'Perceived Norm' and 'Perceived Control') gives the possibility to measure the fit between the actual situation, the perceived result and the chosen intervention. 'Intervention Mapping' provides the framework for the process in which various interventions, training and behavioural changes can occur and that can be used as a guideline in the development of a training or intervention.

The integrated approach is applied and tested in chapter 3, using a supervised control $(N=19)$ - experimental $(N=35)$ group design, to show that the 'Reasoned Action Model' can be used to frame desirable behaviour, as well as to measure the outcome of the intervention. The principles of the 'Intervention Mapping' approach showed, as expected, to be an effective strategy to positively influence behaviour (follow-up after 3 months) in the long term. During the entire process the intervention group showed more improvement on the 'Reasoned Action Model' variables (('Attitude', 'Perceived Norm', 'Perceived Control'and 'Intention') than the control group. In addition 'Intervention Mapping' turned out a concept that increases the selfperception on the actual behaviour of the participants. To be focused on an actual problem and to be guided by the process of 'Intervention Mapping' participants were forced to find a solution that fits their personal problem and circumstances. These results give an answer to the first four main questions of this research. To measure the impact of this model in different situations (question 5) the developed approach is applied, under less controlled conditions, in three international case studies in chapter 4.

The results demonstrate that the 'Reasoned Action Model' provides a good indicator to identify possible barriers to employees regarding the desired behaviour. The principles of 'Intervention Mapping' seemed to be a practical method to frame the problem, to choose an intervention strategy and to measure the results. With regard to the measuring of the effectiveness the developed questionnaire has proven itself. With 'Intervention Mapping' organizations are forced to focus on the objectives (and thus also on the problem), to choose an reasonable intervention strategy and to monitor its impact. Moreover, it has become clear that the factor 'Perceived Norm' of the 'Reasoned Action Model' had an impact on the results of the process. The application of the principles of 'Intervention Mapping' proved extremely practical and supportive. Based on an easy to follow stepwise approach the selected interventions can well be compared with each other. 'Intervention Mapping' also imposes a large part of the responsibility for the chosen solution to the owner of the problem, which improves the visibility and involvement of all.

Because it was impossible to work under controlled circumstances (with a control group), it was necessary to develop an appropriate method for use in the future without a control group. As solution of this practical problem chapter 5 proposes the 'Internal Referencing Strategy' (Garson, 2008; Haccoun \& Hamtieux, 1994), a quasi-experimental research design that infers training effectiveness when trainee pretest-posttest change on training-relevant test items is greater than pretest-posttest change on training-irrelevant test items. Therefore a 
sub-study ( $N=32$ ) was performed in an in-company training for start, performance and assessment interviews within a governmental organization. The target population was divided into an experimental group (which followed the training) and a control group that did not. The previously developed questionnaire, based on the 'Reasoned Action Model', was adjusted for this purpose with behavioural aspects that had little to do with the objective of the training. Also, the research process was designed in a structured program in accordance with the recommended steps of the 'Intervention Mapping' method. The results showed that the 'Internal Referencing Strategy' can be used as an approach in evaluating a training or intervention without using a control group. The presence of a control group is not necessary for the use of the developed instrument and procedure in the future.

In chapter 6 the conclusions of the presented study are given in relation to the main questions of this research. The results have shown that with the developed instrument based on the 'Reasoned Action Approach' the effect of (behavioural) interventions can be measured properly. In that context, 'Intervention Mapping' proved itself as a good supplement during the intervention, because one focusses, on the problem and the desired outcome along with the target participants, which increases the involvement of the target group. By involving them in the development of the instrument, it was easier to describe the outcome criteria. On the factors that have an (direct) impact on the effectiveness of (behavioural) intervention in general, this study can not give a clear answer. However, the developed method provides a practical tool to identify specific factors that influence the effectiveness of an intervention and that promotes or obstruct a desired result. More clarity this research gives regarding the optimization of a (behavioural) intervention. The application of the the 'Intervention Mapping' approach, the involvement of the participants by including them in the chosen intervention and by giving them feedback about barriers and facilitators regarding the intended result, increases the effectiveness of interventions.

This research indicates that by systematic application of 'Intervention Mapping' in combination with an assessment based on the 'Reasoned Action Approach' is a good method to compare studies of different (behavioural) interventions. Based on a clear analysis of the problem, measuring actual (observable) behaviour and focused on measurable results, this approach proved to be very valuable in practice. Finally, a short discussion and recommendations for further research conclude this dissertation. 


\section{Curriculum Vitae}

Michael H.D. Rauner

Koningin Wilhelminalaan 516

2274 BL Voorburg

michael@rauner.nl | michael@cascade-advies.nl

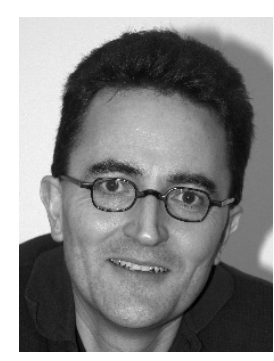

Michael Rauner is van huis uit organisatiepsycholoog en gezondheidswetenschapper en is sinds 1992 adviseur/trainer voor organisaties (en onderdelen van organisaties) die van koers willen wijzigen. Geboren en getogen in Duitsland, verhuisde hij na zijn middelbare schoolopleiding vanwege het studiesysteem aan de Universiteit Maastricht (probleemgestuurd onderwijs) eind 1988 naar Maastricht. Al tijdens zijn studie gaf hij vaardigheidsonderwijs aan geneeskundestudenten en kwam in contact met managementopleidingen. Na de voltooiing van de studie Gezondheidswetenschappen - Geestelijke Gezondheidskunde en een afstudeeronderzoek naar denkfouten bij angststoornissen verhuisde hij naar Leiden voor de opleiding Sociale- \& Organisatiepsychologie én Klinische- \& Gezondheidspsychologie aan de Universiteit Leiden. Ook daar was hij verbonden aan de vakgroep Geneeskunde voor het geven van vaardigheidsonderwijs aan geneeskundestudenten en deed hij onderzoek naar terugdringing van ziekteverzuim in organisaties.

$\mathrm{Na}$ afronding van zijn scriptie in 1995 begon hij zijn carrière als adviseur/trainer bij Orlemans \& Orlemans in Nijmegen. Later wisselde hij naar Schouten \& Nelissen, waar hij een opleiding RET ('Rationeel Emotieve Therapie') volgde en als erkend 'Investor In People' (IIP)-opleider en adviseur diverse adviesopdrachten uitvoerde. In die tijd is zijn interesse gewekt voor dit onderzoek en zijn proefschrift.

Vooral waar het gaat om centralisering of bundeling van organisatieonderdelen, het verzelfstandigen ('sourcen') van bedrijfsonderdelen en het verbeteren van werkprocessen heeft hij zijn sporen verdiend. Ook vervulde hij de afgelopen jaren een aantal bestuurlijke functies, waaronder lid van de Raad van Bestuur van een wijngroothandel (6 jaar) en directeur van een mode-importbedrijf. Sinds 2002 is hij werkzaam bij het Ministerie van Buitenlandse Zaken, waar hij diverse managementfuncties vervult. Onder andere was hij mede verantwoordelijk voor de digitalisering van de informatiehuishouding, betrokken bij de totstandkoming van DocDirekt en lid van de Subcommissie Informatiehuishouding Rijk. Op dit moment is hij directeur van het Erasmushuis in Jakarta, Indonesië. Binnen zijn eigen bureau voor management- en organisatieadvies (Cascade-Advies) heeft hij diverse onderzoeksopdrachten uitgevoerd, waarin hij profit- en non-profitorganisatie ter zijde staat. Hij is erkend Registerpsycholoog NIP, IIP adviseur, testdiagnosticus en heeft diverse gedragsgerichte vakopleidingen gevolgd. De afgelopen 10 jaar heeft hij naast alle werkzaamheden en persoonlijke omstandigheden aan dit proefschrift gewerkt. Zijn motto is 'aan een situatie kun je vaak weinig veranderen, hoe je daarmee omgaat wel'. 


\section{$\underline{\text { Publicaties }}$}

- Arntz, A., Rauner, M. \& Hout, van den M. (1995) | 'If I feel anxious, there must be danger': Ex-consequentia reasoning in inferring danger in anxiety disorders.

Behavior Research and Therapy, 33, 917-925.

- Laquer, M. \& Rauner, M. (2012) | 'Het i-domein in beweging': Samenwerken aan het i-geheugen van het Rijk.

Den Haag - Amsterdam: ICTU - Johan Enschedé.

- Rauner, M., Groot, de S., Kok, G. \& Taris, T. (2009) | 'Betrouwbare effectmeting zonder controlegroep'.

Opleiding \& Ontwikkeling, 22, 15-18.

- Rauner, M., Kok, G., \& Taris, T. (2005) | 'De effectiviteit van een communicatietraining': Een vergelijking van de effectiviteit van een maatwerkprogramma en een standaardprogramma binnen een training effectieve communicatie.

Gedrag \& Organisatie, 19, 3-21. 


\section{Dankwoord}

Allereerst mijn dank aan alle organisaties en deelnemers die aan dit onderzoek hebben meegewerkt. Zij waren bereid extra tijd en energie te investeren in een proces dat niet tot hun dagelijkse doen en laten behoort.

Ook mijn twee promotoren, Toon Taris en Gerjo Kok, ben ik veel dank verschuldigd. Zij hebben mij de afgelopen 10 jaar geïnspireerd en gesteund in het voltooien van dit proefschrift.

Verder wil ik de organisaties Orlemans \& Orlemans en Schouten \& Nelissen bedanken, omdat zij mij in het begin van dit traject de mogelijkheid hebben geboden om mijn onderzoek verder invulling te geven. Zij hebben dan ook in grote mate ertoe bijgedragen, dat organisaties interesse hebben ontwikkeld voor dit proces.

In de persoonlijke sfeer wil ik Madeleine Laqueur en Hans Raben bedanken die mijn ruwe stukken van dit proefschrift van motiverende feedback hebben voorzien. Door hun opmerkingen is de kwaliteit sterk toegenomen. Mijn dank gaat ook uit naar Sanne de Groot, Dieke Buijs, Natasja van Lang, Nico van der Laan en al die vrienden die steeds vragen bleven stellen over de voortgang en de resultaten van mijn onderzoek. Ook ben ik Jacques Leuven dankbaar voor zijn correcties en commentaar.

Uiteindelijk ook veel dank aan Mardy, die mij heel wat uurtjes, weekeinden en zomervakanties heeft moeten missen en mij bleef steunen bij de uitwerking van dit stuk.

Ten slotte wil ik nog mijn medeleven uitspreken aan familie en vrienden van de commissievoorzitter Prof. Dr. Frans Nijhuis. Hij was vanaf de formele aanvraag van mijn promotie tot aan zijn dood in augustus 2015 intensief betrokken bij de voltooiing van dit proefschrift. 


\section{Stellingen}

Stellingen behorende bij het proefschrift: Procesoptimalisatie van gedragsinterventies; een integraal raamwerk ter versterking van de effectiviteit van (gedrags)interventies in organisaties gebaseerd op de 'Reasoned Action Approach' en "Intervention Mapping' '

1. Het proces van gedragstraining kan door toepassing van de 'Reasoned Action Approach' van Fishbein en Ajzen (2010) in kaart gebracht en verbeterd worden. (dit proefschrift, vooral hoofdstuk 3 en 4).

2. De effectiviteit van gedragstrainingen wordt door de factoren van de 'Reasoned Action Approach' van Fishbein en Ajzen (2010) beïnvloed. (dit proefschrift, vooral hoofdstuk 3).

3. De toepassing van de principes van 'Intervention Mapping' (Bartholomew et al., 2006; Schaalma et al., 2001), waarin deelnemers aan gedragsinterventies een terugkoppeling krijgen over de voortgang van de verandering en de mate waarop het beoogde resultaat wordt gerealiseerd, levert een positieve bijdrage aan de optimalisatie van het proces bij gedragsinterventies (dit proefschrift, vooral hoofdstuk 3 en 4).

4. Onderzoeken naar de effectiviteit van gedragsinterventies kunnen alleen met elkaar worden vergeleken, als steeds dezelfde evaluatiemethode wordt toegepast op de gehanteerde interventiemethoden en theorieën (dit proefschrift, vooral hoofdstuk 3, 4 en 5).

5. Door zicht te hebben op de belemmerende en bevorderende factoren van beoogd gedrag en dit inzicht te delen met de doelgroep wordt een beter resultaat bereikt dan wanneer dat niet gebeurt (dit proefschrift).

6. De 'Internal Referencing Strategy' (Garson, 2008; Haccoun \& Hamtieux, 1994) is een betrouwbare methode om de effecten van gedragsinterventies statistisch verantwoord te meten zonder gebruik te maken van een controlegroep (dit proefschrift, vooral hoofdstuk 5).

7. Organisaties die geen systematisch en betrouwbaar onderzoek naar de effecten van gedragstrainingen op prijs stellen, kunnen de kosten voor opleidingen beter direct aan de werknemers uitbetalen en deze zelf een keuze voor een opleiding laten maken waardoor een besparing wordt gerealiseerd in ondersteuning en advies op het gebeid van HRM en management (gebaseerd op IIP en dit proefschrift). 
8. Bij de meeste gedragstrainingen die worden aangeboden, kan het effect moeilijk worden gemeten, omdat duidelijke en meetbare waarnemingen van de beoogde actie (het gedrag zelf), het doel, de context en de tijd ontbreken (dit proefschrift, vooral hoofdstuk 2 en 6 ).

9. Geluk is het gerealiseerde resultaat minus de persoonlijke verwachting over dat resultaat. Bij een negatief resultaat slaat geluk om in misère (eigen waarneming).

10. Vanuit de sociale vergelijkingstheorie kan men voor de Nederlandse context aannemen, dat acceptatie door de burgerbevolking van de door de overheid voorgestelde bezuinigingen gelijk is aan de mate waarin diezelfde overheid zichzelf vergelijkbare bezuinigingen oplegt (gebaseerd op de 'social comparison theory' van Festinger, 1954). 